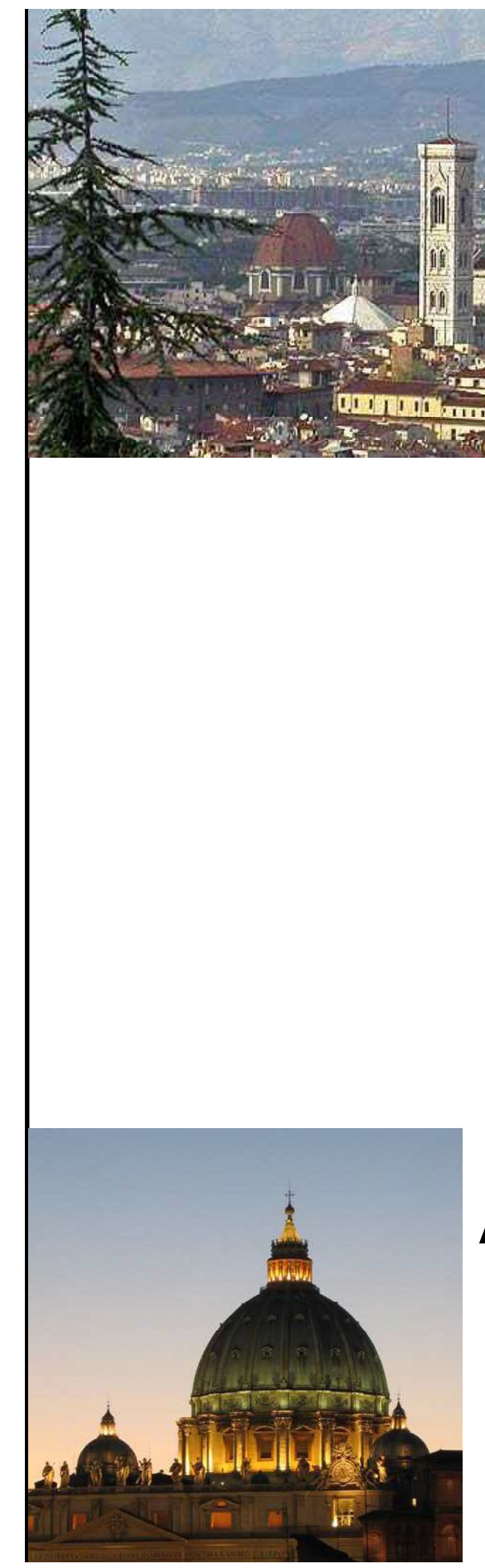

A idéia do Modelo Tridimensional em Arquitetura

Ana Carolina Formigoni Basso Orientador: Prof. Dr. Joubert José Lancha 
Ana Carolina Formigoni Basso

\title{
A idéia do Modelo Tridimensional em Arquitetura
}

\author{
Dissertação apresentada ao Programa de \\ Pós-graduação em Arquitetura e Urbanis- \\ mo da Escola de Engenharia de São Carlos \\ da Universidade de São Paulo, como parte \\ dos requisitos para obtenção do Título de \\ Mestre em Arquitetura e Urbansimo.
}

Orientador: Prof. Dr. Joubert José Lancha 
Dedico esse trabalho aos meus pais, Paulo e Maria, irmãs (e suas famílias), Ana Paula e Maria Cecília, e ao meu marido, Fabiano, que, de qualquer forma, direta ou indiretamente, ajudaram-me a concluir essa pesquisa. 
Agradeço a Deus, porque sem Ele nada disso seria possível. Agradeço a meus pais pela paciência, amor, carinho e compreensão em todos os momentos da minha vida, e principalmente por este. Às minha irmãs e cunhados também pela paciência e ajuda nos momentos em que precisei e não pude resolver. Ao Fabiano, que me incentivou desde o princípio nessa caminhada e sempre esteve ao meu lado com amor e carinho.

Agradeço ao meu orientador, Joubert, que possibilitou e sempre acreditou na nossa pesquisa. Ao Fábio e Maíque pela ajuda no desenvolvimento e enriquecimento do estudo. Aos meus amigos, todos, que presenciaram meu desenvolvimento e me deram forças e colaboração quando mais precisei. Aos funcionários da Arquitetura e da EESC, em geral, que sempre nos auxiliam nesse percurso.

E por fim, à FAPESP, pelo apoio financeiro, e por acreditar no nosso trabalho. 
"Não conhecemos totalmente uma ciência enquanto não sabemos sua história" 


\section{Resumo}

Além do processo de criação, natural às atividades artísticas, a arquitetura apresenta uma forma própria de se expressar. Sua expressão depende de um sistema baseado em símbolos gráficos e elementos representativos que traduzem, da maneira mais clara possível, seu conceito ou idéia arquitetônica.

A convenção desenvolvida para a linguagem da arquitetura, trouxe, além de uma universalização de seus termos, uma forma específica, e abstrata, de expressar a arquitetura, que está sempre presente em sua atividade, desde o momento da criação até sua representação final, pronta para a execução.

O sistema de símbolos de arquitetura, conforme conhecemos hoje, teve sua inicial teorização no Renascimento, o qual considerou suas formas mais importantes de representação: o desenho e o modelo tridimensional.

Ainda que o desenho seja a forma mais habitual de apresentar a arquitetura, a maquete também garantiu sua importância no âmbito da representação arquitetônica.

O presente estudo procura apresentar, além de uma breve história sobre o desenho, tendo em vista seu desdobramento específico para a arquitetura ou construção, a importância da maquete na profissão do arquiteto, através do "nascimento" do modelo tridimensional na arquitetura - assim como o conhecemos hoje. Para alcançar esse objetivo foi realizada uma análise das atividades construtivas no período do Renascimento italiano levando em consideração também, as teorias de estética, que definiram, conjuntamente com outras ciências, a base do saber arquitetônico. 


\section{Abstract}

Apart from the creational process, natural to artistic activities, architecture has its own form of expressing itself. Its expression depends on a system based in graphic symbols and representative elements that translate, as clearly as possible, its architectural concept or idea.

The convention depelopped to architectural langauge brought, besides an universalization of its terms, a specific and abstract form to express architecture, which is always present in its activity, since the moment of creation to its final representation, when it's ready to be executed.

The system of architecture symbols, as we know it today, had it's initial theorization in the Renaissance period, that regarded its most important means of representation drawing and tridimensional model.

Even though drawing is the most usual form to present architecture, the model also gained an important position in the ambit of architectural representation.

This study intends to present, apart from a brief history of drawing, concerning its specific development to architecture or construction, the important role of the mode on the architect's profession, through the "birth" of tridimentional model in architecture - as we know it today. To reach such objective, an analisys of constructive activities in Italian Renaissace was accomplished, also considering aesthetic theories that defined along with other sciences, the basis to architectural knowledge. 
Figura 01 - David Allan, 1773. A origem da pintura. (SAINZ, 1990, p.47).

Figura 02 - Planta de habitação da Mesopotâmia. (OLIVEIRA, 2002, p.185).

Figura 03 - Suposto desenhos cadastral, com cotas, da Mesopotâmia. (OLIVEIRA, 2002, p.185).

Figura 04 - Estátua de Gúdea. (OLIVEIRA, 2002, p.184).

Figura 05 - Planta de Capela Períptera. (OLIVEIRA, 2002, p.188).

Figura 06 - Planta de capela. Museu do Cairo. (OLIVEIRA, 2002, p.184).

Figura 07 - Desenho frontal de Ghorab. (MILLON e LAMPUGNANI, 1994, p.20). .....39

Figura 08 - Desenho lateral de Ghorab. (MILLON e LAMPUGNANI, 1994, p.20). ....... 40

Figura 09 - Fragmentos da "Forma Urbis Roma”. (OLIVEIRA, 2002, p.202). ................. 42

Figura 10 - Fragmentos da "Forma Urbis Roma”. (OLIVEIRA, 2002, p.203). ................. 43

Figura 11 - Pedra tumular. Museu de Perúgia. (OLIVEIRA, 2002, p.204). ....................... 44

Figura 12 - Monastério de St. Gallen (SAINZ, 1994, p.78). ............................................. 47

Figura 13 - Villard de Honnecourt, interior do coro da catedral de Reims, 1230. (ACKERMAN, 2003, p.35).

Figura 14 - Elevação da fachada da catedral de Strasburgo, século XIV. (ACKERMAN, 2003, p.41)

Figura 15 - Projeto para a fachada de Orvieto, 1320. (ACKERMAN, 2003, p.43). .......... 51

Figura 16 - Giotto (?), projeto para o campanário da catedral de Florença, elevação, século XIV. (ACKERMAN, 2003, p.44)

Figura 17 - Detalhe do projeto de Giotto para o campanário de Florença. (ACKERMAN, 2003, p.42). 
Figura 18 - Antonio di Vicenzo, planta e corte parcial da nave da catedral de Milão, 1390 (cópia moderna). (ACKERMAN, 2003, p.46).

Figura 19 - Hans Hammer, máquina de construção, im do século XV (ACKERMAN,

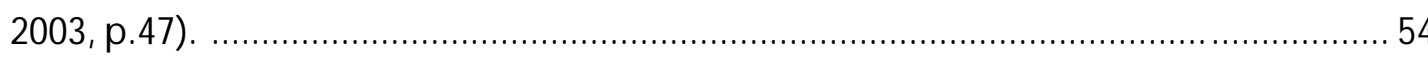

Figura 20 - Pisanello, primeira metade do século XV. Interior com figuras; perspectiva. (LOTZ, 1985, p.42)

Figura 21 - Andrea Palladio, estudo para a elevação e corte da fachada do edifício

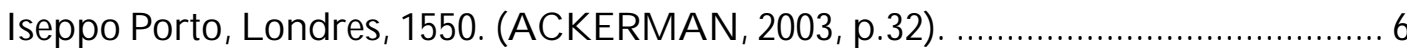

Figura 22 - Antonio da Sangallo, o Jovem. Projeto para São Pedro, Roma. (LOTZ, 1985,

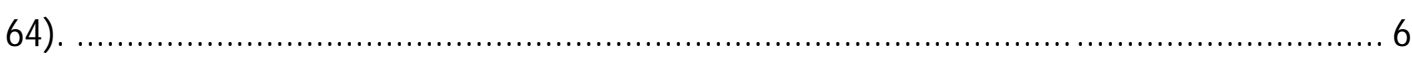

Figura 23 - Antonio da Sangallo, o Jovem. Projeto para um edifício centralizado. (LOTZ, 1985, p.64)

Figura 24 - Giuliano da Sangallo. Tumbas romanas, anterior a 1514. (ACKERMAN,

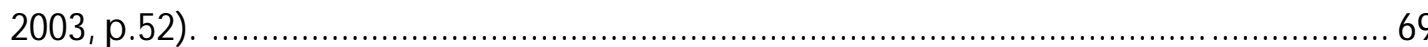

Figura 25 - Sebastiano Serlio. Projeto de Bramante para a cúpula de São Pedro, Roma, 1514. (ACKERMAN, 2003, p.53)

Figura 26 - Bernardo della Volpaia. Corte em perspectiva do Pantheon, 1515. (ACKERMAN, 2003, p.54) 71

Figura 27 - Andrea Palladio. Planta, corte e elevação. Villa Rotonda, Vicenza, 1567. (HEYDENREICH, 1998, p.156).

Figura 28 - Piero della Francesca. Escorço do cérebro humano. De prospettiva pingendi, 1490. (ACKERMAN, 2003, p.58). ................................................................................ 74

Figura 29 - William Farrish. Máquina. (ACKERMAN, 2003, p.256). .76

Figura 30 - Baldassari Peruzzi. Projeto para a continuação da construção de São Pedro, Vaticano, 1534-35. (LOTZ, 1985, p.23). 77

Figura 31 - Auguste Choisy. Abóbada romana., 1883. (ACKERMAN, 2003, p.258). ..... 78

Figura 32 - Filippo Juvarra. Vista do Castelo de Rivoli, 1721. (SAINZ, 1990, p.26). ...... 79

Figura 33 - Lâmina de Géométrie descriptive. Gaspard Monge. (SAINZ, 1990, p.51). ..... 81

Figura 34 - Máquina de Pontear (WITTKOWER, 1989, p.25)
Figura 35 - Le Corbusier, projeto para o interior da casa "Les Terrasses", em Garches (ACKERMAN, 2003, p.253)

Figura 36 - Frank Gehry, estudo para o museu Guggenheim de Bilbao, Espanha.

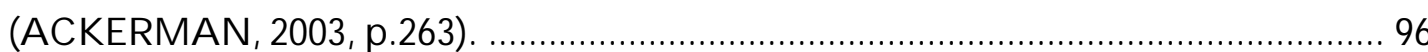

Figura 37 - Frank Gehry, museu Guggenheim de Bilbao, Espanha. (www.artlex.com).....

Figura 38 - Piero della Francesca. Vista em perspectiva de uma cúpula. (MILLON e LAMPUGNANI, 1994, p.111)

Figura 39 - Leon Battista Alberti. Fachada do Templo Malatestiano de Rimini. (MILLON e LAMPUGNANI, 1994, p.83)

Figura 40 - Andrea Palladio. Basílica de Vicenza, iniciada em 1549. (LOTZ, 1998, p.153) 119

Figura 41 - Catedral de Milão. Tibúrio. (PANOFSKY, 1979, p.257)

Figura 42 - Gherardo Silvani. Modelo para a fachada da Catedral de Florença. (PANOFSKY, 1979, p.263).

Figura 43 - Alberti. Santa Maria Novella, Florença, 1458. (HEYDENREICH, 1998, p.39). 122

Figura 44 - Esboço de trabalho de escultor egípcio (papiro). (PANOFSKY, 1979, p.95).... 125

Figura 45- Esquema de Três Círculos da Arte bizantina e bizantinesca. (PANOFSKY, 1979,

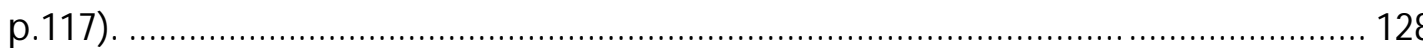

Figura 46 - Villard de Honnecourt, página do Caderno de Notas, 1235. (WITTKOWER, 1979 , p.526)

Figura 47 - Leonardo da Vinci. Estudo das proporções humanas (mostra as razões

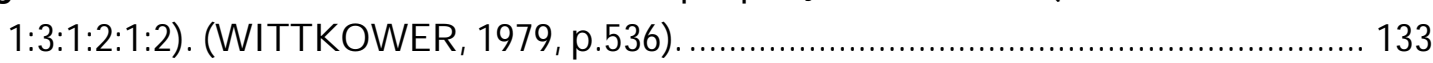

Figura 48 - Giuliano da Sangallo. Santa Sofia, Roma. (LOTZ, 1985, p.43). 137

Figura 49 - Bramante. Santa Maria presso San Satiro. (MILLON e LAMPUGNANI

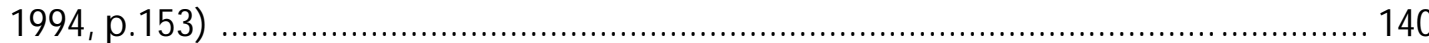

Figura 50 - Esquema da perspectiva a partir de ângulo visual. (WITTKOWER, 1979, p.545) 
Figura 51 - Santa Maria del Popolo, Roma, por Thiersch. (WITTKOWER, 1979, p.546) 145

Figura 52 - Esquema de Semelhança de Triângulos. Estudos de Piero della Francesca.

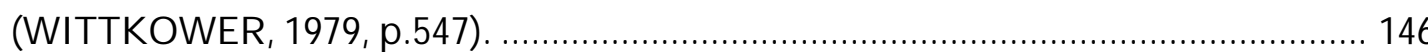

Figura 53 - Interior de Santo Spirito, Florença. Brunelleschi (WITTKOWER, 1979, p.542).

Figura 54 - Interior de San Lorenzo, 1421. Florença. Filippo Brunelleschi. (HEYDENREICH, 1996, p.16)

Figura 55 - Capela Chigi, S. Maria del Popolo, Roma, 1513. Corte e planta. Rafael. (LOTZ, 1998, p.28)

Figura 56 - Capela Chigi, S. Maria del Popolo, Roma, 1513. Rafael. (LOTZ, 1998, p.28).... 151

Figura 57 - Modelo de casa encontrado em Mari. (OLIVEIRA, 2002, p.188), 156

Figura 58 - Reconstituíção de maquete de um templo. (OLIVEIRA, 2002, p.191). ...... 157

Figura 59 - Maquete de jardim de um nobre. (OLIVEIRA, 2002, p.191)....................... 157

Figura 60 - Modelo romano em pedra. (OLIVEIRA, 2002, p.208). ................................. 159

Figura 61 - Retrato do arquiteto Hugh Libergier, 1267. (KOSTOF, 1977, p.78) ............ 161

Figura 62 - Iluminura medieval. (OLIVEIRA, 2002, p.246) .......................................... 161

Figura 63 - Relevo feito para comemoração da fundação da Catedral Ulm, 1377 (KOSTOF, 1977, p.82,

Figura 64 - De Giorgio Vasari. Brunelleschi apresentando o modelo para Cósimo de Médici. (KOSTOF, 1977, p.110)

Figura 65 - Modelo em madeira para a fachada de São Lorenzo. (MILLON e LAMPUGANI, 1994, p.47).

Figura 66 - Michelangelo apresent a ao papa Leone X o modelo para a fachada de San Lorenzo. (MILLON e LAMPUGANI, 1996, p.46). ....................................................... 174

Figura 67 - Cúpula da catedral de Florença - Santa Maria del Fiore. Brunelleschi. (MILLON e LAMPUGNANI, 1994, p.124) …………………........................................ 183

Figura 68 - Modelo em madeira para a cúpula de Santa Maria del Fiore. Brunelleschi.
(MILLON e LAMPUGNANI, 1994, p. 23). 186

Figura 69 - A cúpula da catedral de Florença. (MURRAY, 1972, p.23) 187

Figura 70 - Vista panorâmica de Florença. 188

Figura 71 - Catedral de Florença - construção da cúpula. (HEYDENREICH, 1998, p.13)...

Figura 72 - esquema da fixação dos andaimes projetados por Brunelleschi, para o início

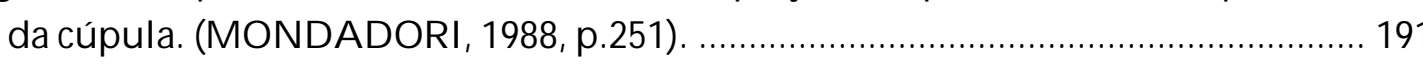

Figura 73 - esquema da fixação dos andaimes projetados por Brunelleschi, para o começo da curvatura da cúpula. (MONDADORI, 1988, p.251).

Figura 74 - esquema da fixação do andaime projetado por Brunelleschi, para o término da construção da cúpula. (MONDADORI, 1988, p.251). ........................................... 192

Figura 75 - planta do andaime projetado por Brunelleschi, para o término da construção da cúpula. (MONDADORI, 1988, p.251).

Figura 76 - Modelo em madeira para o lanternim da cúpula. Brunelleschi. (MILLON e

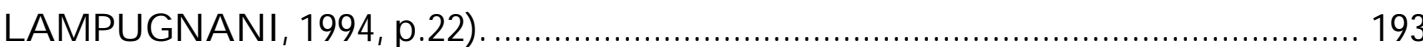

Figura 77 - Lanternim da cúpula da catedral de Florença. (MURRAY, 1972, p.34). .... 193

Figura 78 - Donato Bramante. Projeto para a basílica de São Pedro, planta. (LOTZ, 1998, p.18)

Figura 79 - Baldassari Peruzzi. Projeto para a basílica de São Pedro, planta. (LOTZ, 1998, p.24)

Figura 80 - Rafael (cópia). Projeto para a basílica de São Pedro, elevação e corte. (LOTZ, 1998, p.24).

Figura 81 - Rafael (cópia). Projeto para a basílica de São Pedro, planta. Antonio da Sangallo (cópia). Projeto para a mesma basílica, planta. (LOTZ, 1998, p.25). .......... 200

Figura 82 - Rafael. Projeto para a basílica de São Pedro, corte do deambulatório e elevação do transepto, desenho de Antonio da Sangallo, o Jovem. (LOTZ, 1998, p.25)

Figura 83 - Antonio da Sangallo, o Jovem. Projeto para a basílica de São Pedro, planta.

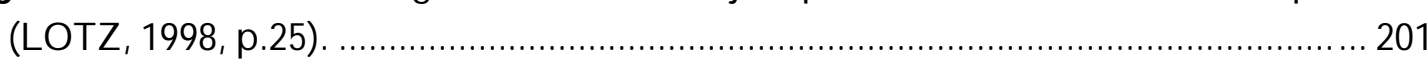


Figura 84 - Modelo em madeira para o projeto de São Pedro. Fachada. Antonio da Sangallo, o Jovem. (MILLON e LAMPUGNANI, 1994, p.35)

Figura 85 - Modelo em madeira para o projeto de São Pedro. Face sul. Antonio da Sangallo, o Jovem. (MURRAY, 1972, p.163) ............................................................... 203

Figura 86 - Modelo em madeira para o projeto de São Pedro. Interior. Antonio da Sangallo, o Jovem. (MILLON e LAMPUGNANI, 1994, p.41)

Figura 87 - Antonio da Sangallo, o Jovem. Corte transversal do projeto para a basílica de São Pedro. Gravura de Salamanca. (LOTZ, 1998, p.55).

Figura 88 - Modelo em madeira da cúpula de Michelangelo para a basílica de São Pedro. Alterações de Della Porta. (MILLON e LAMPUGNANI, 1994, p.44) ........... 206

Figura 89 - Interior do modelo em madeira da cúpula de Michelangelo para a basílica de São Pedro. Alterações de Della Porta. (MILLON e LAMPUGNANI, 1994,

p.45)

Figura 90 - Basílica de São Pedro. Projeto de Michelangelo, planta, 1546. (LOTZ, 1998,

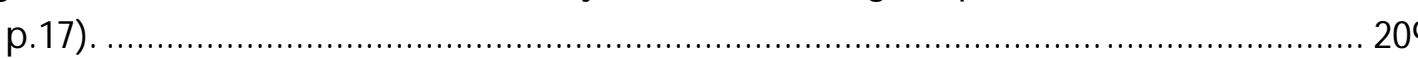

Figura 91 - Basílica de São Pedro, construção 1506-1564. (LOTZ, 1998, p.56). .............. 210

Figura 92 - Basílica de São Pedro, abside sul, projetada por Michelangelo em 1546, concluída em 1564. (LOTZ, 1998, p.100).

Figura 93 - Desenho anônimo, mostrando o cruzeiro em construção, por volta de 1553

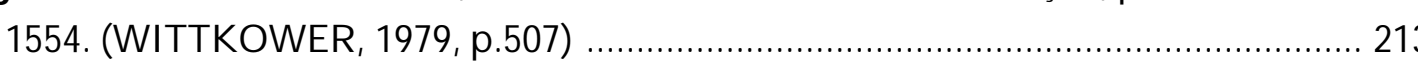

Figura 94 - G. A. Dosio. Vista norte do cruzeiro, 1562. (WITTKOWER, 1979, p.507)....... 214

Figura 95 - Perspectiva, possivelmente de Ammanati, do cruzeiro. Vista oeste, 1562. (WITTKOWER, 1979, p.508).......................................................................... 215

Figura 96 - Desenho anônimo, mostrando São Pedro em vista noroeste, 1566-1567. (WITTKOWER, 1979, p.508)

Figura 97 - Detalhe de uma gravura em madeira de 1565, mostrando já completa a parte do entablamento do tambor. (WITTKOWER, 1979, p.509).

Figura 98 - Michelangelo (?). Estudo para o tambor e a cúpula. (WITTKOWER, 1979 p.511)
Figura 99 - Diagrama que mostra a construção da cúpula, a partir de três centros. (WITTKOWER, 1979, p.513)

Figura 100 - S. Dupérac. Seção longitudinal de São Pedro, baseada no projeto de Michelangelo, gravura. (WITTKOWER, 1979, p.514)

Figura 101 - S. Dupérac. Elevação exterior de São Pedro, baseada no projeto de Michelangelo, gravura. (WITTKOWER, 1979, p.514)

Figura 102 - S. Dupérac. Exterior da cúpula, baseado no projeto de Michelangelo gravura. (WITTKOWER, 1979, p.520)

Figura 103 - Letarouilly. Exterior da cúpula tal como foi construída, gravura. (WITTKOWER, 1979, p.520)

Figura 104 - S. Dupérac. Interior da cúpula, baseado no projeto de Michelangelo, gravura. (WITTKOWER, 1979, p.521)

Figura 105 - Letarouilly. Interior da cúpula tal como foi construída, gravura. (WITTKOWER, 1979, p.520) 
Capítulo 02. O modelo tridimensional em arquitetura: noções gerais

Capítulo 03. Renascimento: teorias e humanistas

Teoria das Proporções

A Perspectiva

Capítulo 3.1. O modelo tridimensional da arquitetura do Renascimento

Capítulo 04. Dois estudos

Brunelleschi e a cúpula de Santa Maria del Fiore

A Basílica de São Pedro e a cúpula de Michelangelo 195

A cúpula de Michelangelo

Considerações finais e propostas futuras

Propostas futuras 
Introdução: A representação em Arquitetura

Desenhar, em geral, é plasmar sobre uma superfície plan bidimensional a imagem de um volume tridimensional com os recursos dos sistemas de geometria descritiva e projetiva, para conseguir a transposição de três para duas dimensões. (SAINZ, 1990, p. 199). 
Acredita-se que o homem primitivo registrava suas imagens, que pareciam de certa forma, cópias de corpos do mundo sensível, na tentativa de reter idéias e fatos acontecidos. A necessidade de reproduzir e criar um universo de representação foi de grande importância no desenvolvimento do pensar. Ao exteriorizar o pensamento, gera-se um conjunto de informações, advindas de desenhos, de escritos, diagramas, que recriam uma realidade e tornam possível sua manipulação e interferências externas.

$\mathrm{O}$ ato de projetar passa por esse processo. Antes de se iniciar um projeto, há uma série de problemas e demandas que norteiam o pensamento do arquiteto. A partir de então, a ação de projetar passa por dois momentos: o de exteriorizar as idéias do edifício, de forma rápida e sem regras específicas; e o de construir segundo um sistema próprio de representação, codificado convencionalmente, para a exata execução do projeto idealizado. À primeira etapa, cabem os desenhos imediatos como croquis e esboços, e frente à precisão que a execução requer, cabem os desenhos técnicos de arquitetura. Em ambas as etapas desse processo, pode-se também incluir, além de desenhos, o uso de modelos tridimensionais, tanto para auxiliar na concepção, quanto para expressar a melhor solução alcançada.

O croqui, por sua natureza, pode ser considerado a primeira manifestação do pensamento, da idéia do arquiteto. Em alguns casos adiciona-se a esse movimento, um modelo tridimensional de estudo, possivelmente precário em seus materiais, mas que, assim como o croqui, representa um importante veículo para a formação da imagem do objeto idealizado, como experimentação e parte do processo do conhecimento e desenvolvimento da idéia projetada. 
Os sistemas gráficos que traduzem a tridimensionalidade do objeto para o plano bidimensional são atualmente conhecidos por: perspectivas com ponto de fuga (linear ou central), perspectiva geométrica (axonometria), e as projeções ortogonais - plantas, elevações e cortes, que entre todas pode ser considerada a forma de representação mais abstrata em relação à materialidade do objeto. Aliados a esse sistema, podem ser incluídos os modelos de apresentação para concursos ou clientes e os modelos experimentais para a construção de algum detalhe ou mesmo do todo.

A convencionalização do desenho de arquitetura aparece inicialmente com Vitruvio, que registrou as primeiras definições que tornaram esse tipo de desenho inteligível. A partir dele, alguns grandes nomes da Renascença, como Alberti, Scamozzi, Palladio, Rafael, continuaram a desenvolver e codificar o sistema ortogonal de representação, definido cientificamente por Gaspard Monge em 1798, e ainda utilizado atualmente.

A origem do modelo tridimensional em arquitetura é incerta. Sabe-se do uso de modelos tridimensionais na representação de algo construído ou até mesmo com simbologia religiosa na Antiguidade, porém não se pode precisar quando o modelo passou a significar notoriamente um meio de representação e estudo em arquitetura. Há várias suposições sobre essa origem, como por exemplo, a transposição, para arquitetura, do modelo realizado por escultores para conceber e executar grandes peças; ou ainda, como uma forma de garantir o entendimento do projeto e a autoria da obra, independente do tempo de sua construção. Pode-se atribuir à Renascença, o momento de nascimento do modelo ou maquete que se conhece hoje, mas com o passar do tempo, novos materiais e novas técnicas trouxeram mudanças na execução desses objetos tridimensionais.

De certa forma, o modelo sempre esteve presente na história da arquitetura, ora caminhando paralelamente ao desenho, ora confundindo-se com ele. O modelo, assim como o termo mesmo sugere, é

Desenho ou imagem que representa o que se pretende reproduzir, desenhando, pintando ou esculpindo./Tudo o que serve para ser imi Representação, em pequena escala, de um objeto que se pretende executar em ponto grande (Dicionário Michaelis de Língua Portuguesa).

Apesar de sua presença constante na prática da arquitetura, poucos são os relatos sobre o uso de modelos pelos arquitetos.

Com a industrialização, o desenho técnico passou a se desenvolver também em outras áreas, a fim de garantir a rigorosa construção, com informações precisas, de muitos objetos que seriam produzidos em série. No século XVIII, o desenho técnico já estava completamente definido em seu sistema ortogonal (plantas, elevações, cortes e perspectivas precisas), e estava aprimorando suas especificações atuais, como códigos de representação de materiais, textos, e outras informações necessárias. Nesse momento, o modelo físico parece desaparecer, os livros e ensinamentos não esclareciam sua utilização, ainda que em alguns documentos houvesse registrada a atividade de modelagem por arquitetos da modernidade. Com o advento da indústria, o modelo assumiu 
um novo conceito, o de protótipo, que segundo o Dicionário Michaelis significa "primeiro tipo; primeiro exemplar; modelo, padrão / o exemplar mais exato, de maior perfeição." Além desse objeto, que apesar de se colocar como novo, também significa um tipo de modelo tridimensional físico, o desenvolvimento da perspectiva geométrica possibilitou o uso gráfico, bidimensional, para a representação do modelo com toda sua proporção e dimensionamento precisos.

Com o advento da informática e avanço de novos recursos para a representação, o desenho de arquitetura sofreu ainda mais algumas mudanças, como a simulação gráfica do projeto idealizado, apenas com a construção do desenho em linhas e a definição de parâmetros, necessários para a construção virtual do projeto no sistema gráfico de representação e na tridimensionalidade eletrônica. A simultaneidade da construção do desenho e da geração de perspectivas ou maquetes virtuais renova a ligação entre a representação gráfica e o objeto tridimensional idealizado, de uma forma mais instantânea e aumentando a velocidade do processo projetual.

O objetivo principal desse estudo é apresentar as premissas presentes no surgimento e desenvolvimento do modelo tridimensional em arquitetura. Na maioria das vezes, o modelo não se apresenta sozinho no sistema de representação arquitetônico, mas como um elemento comprobatório de um projeto que se apresenta em símbolos gráficos, ou seja, em desenho. Portanto, inicialmente esse trabalho apresenta um panorama geral sobre a história do desenho, principalmente sua aplicação em arquitetura ou construção. Em seqüência, é analisado um grande momento da história da arquitetura: o Renascimento, onde foram consolidadas e teorizadas as bases do saber arquitetônico que se seguiu até os dias atuais e onde se tem maior registro da atividade de modelos tridimensionais em arquitetura. A título de exemplificação, há a breve descrição de dois projetos do Renascimento italiano, apresentando e comprovando o uso de maquetes em arquitetura.

Na conclusão desse estudo, é apresentada uma rápida visão (ou indagação) sobre o uso de modelos na arquitetura moderna e contemporânea, como forma de incentivar pesquisas posteriores

O primeiro capítulo introduz algumas referências sobre Apresentação o desenho arquitetônico, sob um ponto de vista histórico na dos capítulos bidimensional, ou seja, as projeções ortogonais - planta, elevação e corte - e perspectivas.

O segundo capítulo apresenta de forma geral, os conceitos e caracterizações do modelo tridimensional arquitetônico.

O terceiro capítulo se constitui de duas partes maiores, sendo a primeira dividida em mais alguns assuntos. Em um primeiro momento pretende-se criar uma aproximação às condições sociais e, principalmente, artísticas do Renascimento italiano, período que teorizou e sistematizou a representação de arquitetura. Há ainda uma apresentação das teorias que envolveram todo o pensamento científico da época, bem como o surgimento do modelo tridimensional em arquitetura, conforme conhecemos ainda hoje, e que é o escopo da segunda parte desse capítulo. 
Para exemplificar toda teoria até aqui discutida, no quarto capítulo, há a apresentação de duas obras: a cúpula de Santa Maria Del Fiore, de Brunelleschi, século XV, e a história da construção da Basílica de São Pedro, século XVI, na qual a importância maior é dada à cúpula de Michelangelo e seu imenso modelo tridimensional.

Por fim, como meio de sintetizar e confrontar todo o conteúdo analisado, as conclusões aparecem também como uma intenção de propostas futuras, principalmente em relação à arquitetura moderna e contemporânea, na tentativa de dar continuidade à pesquisa sobre o modelo tridimensional na prática da arquitetura. 
Embora o escopo desse estudo tenha como tema o uso do modelo tridimensional em arquitetura, não se pode ignorar a grande e importante presença do desenho na concepção e representação arquitetônica. Mais que um instrumento de uso de arquitetos para representar seus projetos, o desenho faz parte da própria essência da arquitetura, e sem ele a evolução da arte de construir teria encontrado muitos problemas.

O desenho em arquitetura também estabelece um percurso que varia com a época em que está inserido, segundo sua técnica de representação, instrumentos utilizados e pensamentos vigentes no período.

Como no caso da arquitetura, a história do desenho arquitetônico não é somente uma sucessão de resultados gráficos distintos, mas também reflete uma série de usos do desenho que foram sendo modificado progressivamente; o mesmo pode dizer-se dos aspectos formais ou técnicos da representação. (SAINZ, 1990, p.42).

Odesenho de arquitetura percorreu um longo caminho até poder ser definido como tal. O primeiro indício seria a origem do desenho de representação, que com o tempo foi ganhando inserções cada vez maiores e mais apropriadas para o uso na arquitetura. Ao mesmo tempo esse desenho foi se apropriando de novas formas e regras específicas, principalmente no intento de tornar-se um meio de comunicação entre arquitetos e entre esses e seus colaboradores e clientes.

Não se pode negar a atividade de desenhar nas antigas culturas e arquitetura medieval, porém raras são as provas 
desses desenhos. Ackerman (2002) cita algumas exceções; “alguns papiros egípcios, a planta marmórea de Roma, uma elevação em escala 1:1 do tímpano do Pantheon, recuperado recentemente, além da planta sobre pergaminho do monastério de St. Gallen". (ACKERMAN, 2003, p.29).

Faremos nesse capítulo, um breve resumo da história do desenho de representação, procurando sempre se pautar sobre o tema da arquitetura, quando possível. Há diferentes exemplos de representação de arquitetura, cada qual com sua importância para o entendimento dos motivos pelos quais o desenho arquitetônico encontra-se embasado sobre o sistema, ainda atual, de projeções ortogonais e representações visuais, como perspectivas, e até mesmo modelos tridimensionais.

Ainda que a história da arquitetura tenha desenhos e maquetes como provas de sua existência, nesse momento nos referiremos apenas aos documentos gráficos, deixando o modelo tridimensional para uma segunda parte, para que esse tenha uma ênfase e aprofundamento maior, já que se caracteriza como o objeto de estudo desse trabalho.

Ackerman, em seu texto Convenzioni e retórica nel disegno architettonico, faz considerações sobre os instrumentos e materiais de desenho. Para ele, o papel, introduzido no mundo ocidental apenas no século XIV, traz pela primeira vez a possibilidade de

(...) fixar idéias e sugestões em forma de esboços. Até esse momento, de fato, vinha sendo utilizado o pergaminho, reservado, contudo à representação dos desenhos definitivos, pois geralmente era muito caro e pouco apto a esboços e estudos preparatórios. (ACKERMAN, 2003, p.249)
Figura 01 - David Allan, 1773. A origem da pintura. (SAINZ 1990, p.47).

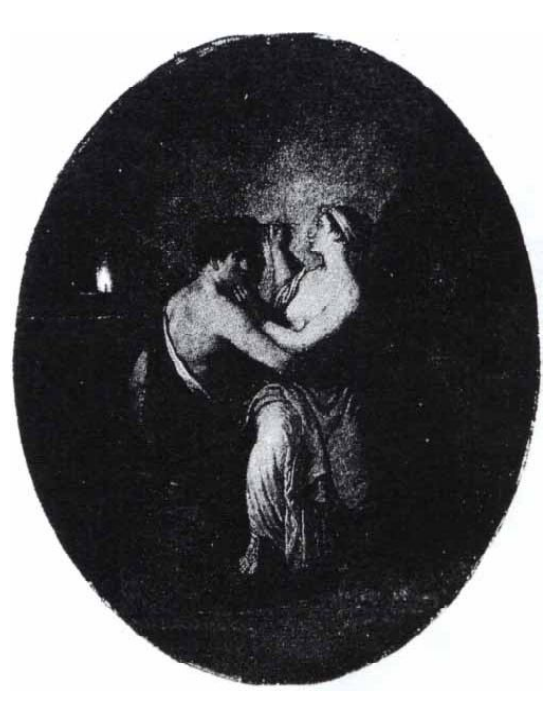

Atualmente, restam poucos exemplos de desenhos sobre pergaminhos. Além de ser de material de alto custo, sua robustez permitia desenhar e apagar ou mesmo raspar, para que fosse reaproveitado, nem sempre com outros desenhos, mas também com textos.

Durante todo o século XIX, surgiram vários ensaios que relataram, de diversas maneiras, a origem do desenho de representação. Conta-se, segundo uma lenda de Cayo Plínio Segundo em seu Historia Natural, escrito no século I d.C., que Figura 01 o desenho teve origem quando a filha de um alfaiate chamado Dibutades, traçou sobre uma parede o contorno da figura de seu amado, para não esquecê-lo quando ele partisse. Essa lenda apresenta o primeiro contorno na definição de uma figura através de linhas, e ainda adquire importância por ser anterior a qualquer obra artística, pintura, escultura ou mesmo arquitetura.

Pode-se dizer que a representação de arquitetura aparece de duas formas no decorrer da história sobre o desenho. Na primeira delas, a arquitetura torna-se apenas uma base para o ambiente que se pretende mostrar, ou seja, tornase um elemento na composição de um ato ou de uma paisagem 
na pintura, ou mesmo, em um objeto ou gravura. A segunda, que podemos conceituar como a representação técnica da arquitetura, apesar de não ter maior importância que a primeira, representa a arquitetura que se pretende construir, com seus símbolos e expressões próprias para alcançar seu objetivo, a realização de um estudo.

Apesar da distinção entre as formas de apresentação da arquitetura, em desenhos, queremos deixar claro, a importância da presença da arquitetura nas obras de pintura, mural ou em tela. A partir desse tipo de representação, podese apreender o que se ansiava para a arquitetura da época, e como essa se relacionava com a sociedade, quais eram suas principais características e detalhes de ornamentação.

O desenho há muito acompanha a história da humanidade. Pode-se dizer que os símbolos primitivos em forma de desenhos já indicavam a necessidade do homem em expressar seu pensamento, de acordo com sua vivência. Embora saibamos que o Desenho é uma instância ampla, tentaremos nesse estudo apresentar indícios de seu uso para a construção, ainda que sua forma de representação seja muito precária em comparação com a atual, mais próxima a nós.

Dessa forma podemos citar a presença do desenho desde a Mesopotâmia. Nesse período, apesar de suportes e instrumentos precários (aos nossos olhos), já havia a necessidade de representação de construção, embora não seja possível precisar seu verdadeiro uso. A forma de representação era a de projeções ortogonais, mesmo assim, apenas com plantas e elevações bem simples, e não há indícios de cortes. Segundo o professor Mário Mendonça de Oliveira, em seu livro Desenho de Arquitetura Pré-Renascentista (2002), podem ser
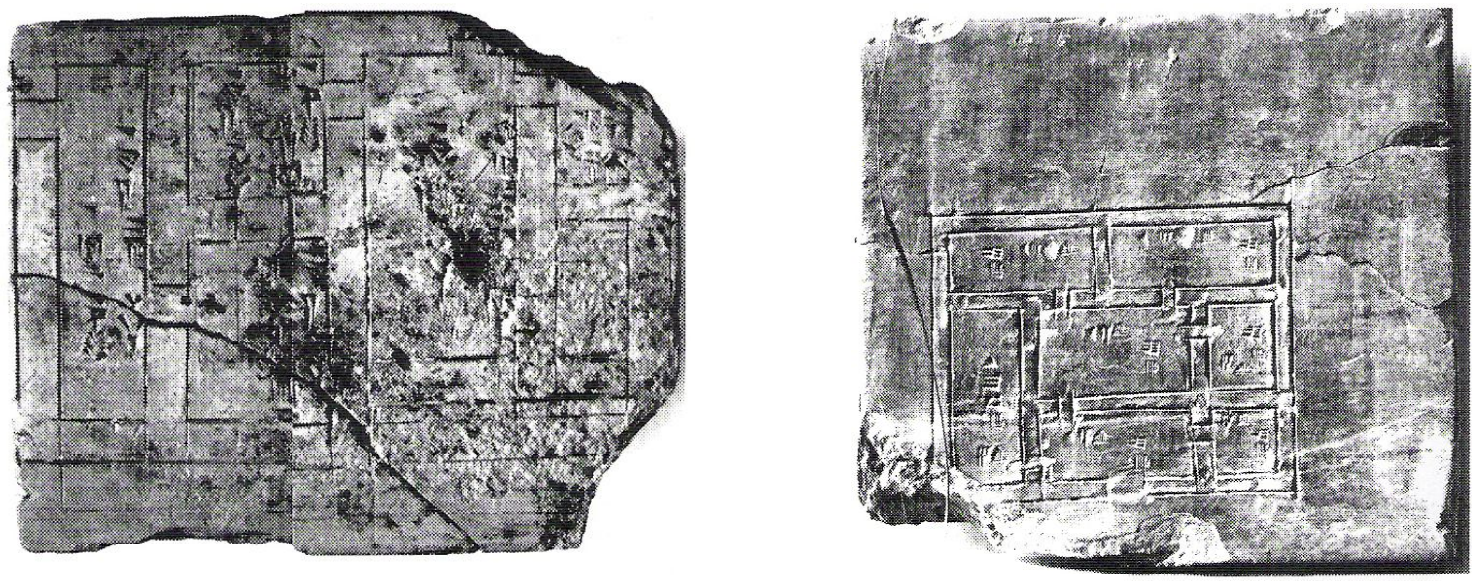

Figura 02 (esquerda) - Planta de habitação da Mesopotâmia. (OLIVEIRA, 2002, p.185).

Figura 03 (direita) - Suposto desenhos cadastral, com cotas, da Mesopotâmia. (OLIVEIRA, 2002, p.185) classificados três principais tipos de desenhos presentes na Mesopotâmia: realização de construção, cadastro e documentação, e simbolismo. Como realização de uma construção, citamos uma planta simples, de uma habitação, que apesar de bastante danificada, pode-se perceber o traçado duplo das paredes e aberturas, indicando passagens. No entanto, como não há nenhum outro documento que comprove

Figura 02 o uso de desenhos para a construção, supõe-se que as representações de construção e de cadastro possam ser confundidas entre si. Por ser uma civilização de atividade comercial, era muito freqüente o uso de desenhos para cadastros e inventários de casas e propriedades. Novamente supõem-se desenhos cadastrais, por apresentarem referências

Figura 03 como textos de dimensões, espécie de cotas. O simbolismo esteve e continua presente em toda a história do desenho. No caso da Mesopotâmia, temos o exemplo de uma estátua de

Figura 04 Gudea , onde o artista procurou mostrar que o personagem representado dedicava-se à arquitetura, o que era considerada uma atividade intelectual, de domínio de poucos, principalmente de sacerdotes.

Assim como na Mesopotâmia, o Egito também deixou resquícios sobre o uso de desenhos de construções. No entanto, esse material que chegou até nós é mais abundante, 

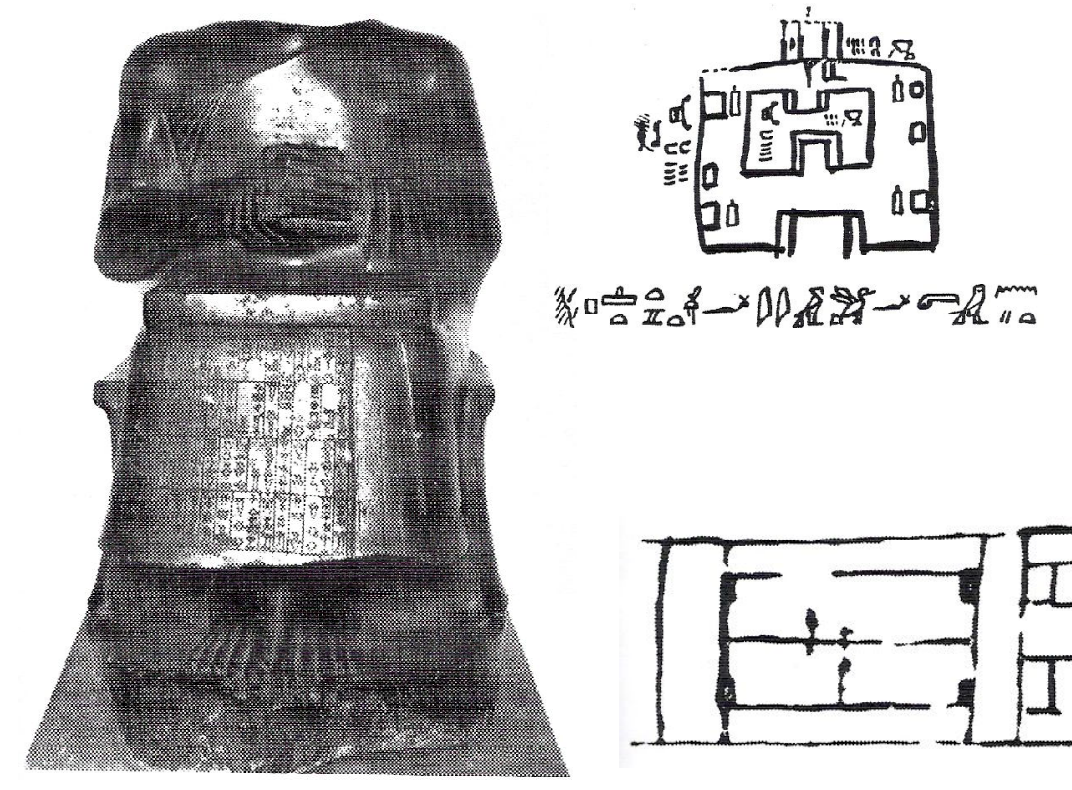

igura 04 (esquerda) - Estátua de Gúdea. (OLIVEIRA, 2002, p.184).

Figura 05 (ao lado) - Planta de Capela Períptera. (OLIVEIRA 2002, p.188).

Figura 06 (abaixo) - Planta de capela. Museu do Cairo. (OLIVEIRA, 2002, p.184

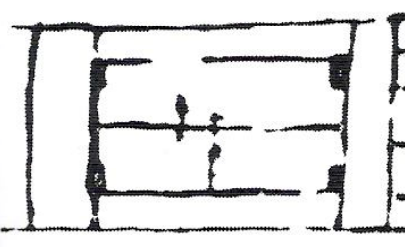

ILसUII IIITIII

quer por motivos da cultura - de grande tendência para a comunicação visual, quer pelas condições climáticas favoráveis à conservação. Os exemplos de desenhos de arquitetura se referem ao período entre o Médio Império até a Baixa Época, que culmina com a ocupação romana. Novamente podem ser classificados os desenhos encontrados: execução de projetos, inventários, mapas com itinerários de viagens e monumentos. A maior finalidade do desenho de representação era a de arquitetura, ou seja, para a construção. O sistema utilizado também era de projeções ortogonais, porém com uma característica muito interessante, o rebatimento de portas e elementos importantes para a representação da construção. Figuras 05 e 06

Os desenhos eram feitos sobre pedra - "ostraca", cerâmica, e principalmente o papiro, cuja invenção se atribui ao Egito. $\mathrm{O}$ pergaminho procurou substituir o papiro, mas seu alto custo dificultava sua utilização. O exemplo de maior riqueza em técnica e execução do Egito é o projeto de um "naos", ainda que não represente um edifício. Trata-se de uma elevação frontal e lateral para a execução de um objeto, feito sobre papiro, encontrado em Ghorab, e provavelmente realizado no

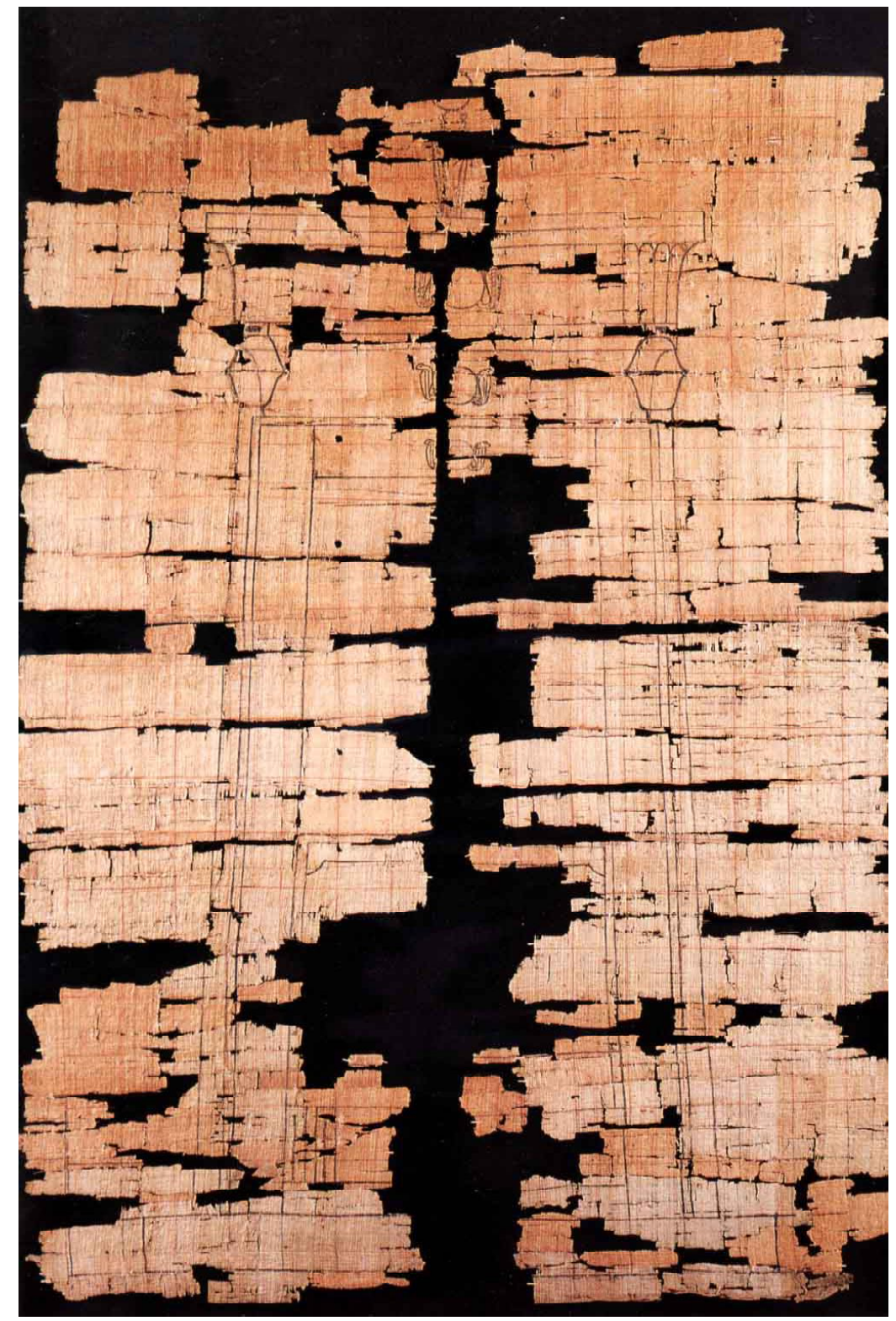

Figuras 07 e 08

Novo Império. Nesses desenhos há a presença da quadrícula, o que se acredita estar presente em todas as formas de desenhos no Egito, quer para modular o projeto, objeto ou figura; quer para auxiliar em ampliações e reduções. A malha de apoio ao desenho era feita em tinta vermelha e o desenho em tinta preta. A linha central da retícula também era utilizada como eixo de simetria, outro grande artifício utilizado nas construções do Egito.

Como seqüência na referência do uso de desenhos de arquitetura no Mundo Antigo, colocamos a Grécia e Roma 


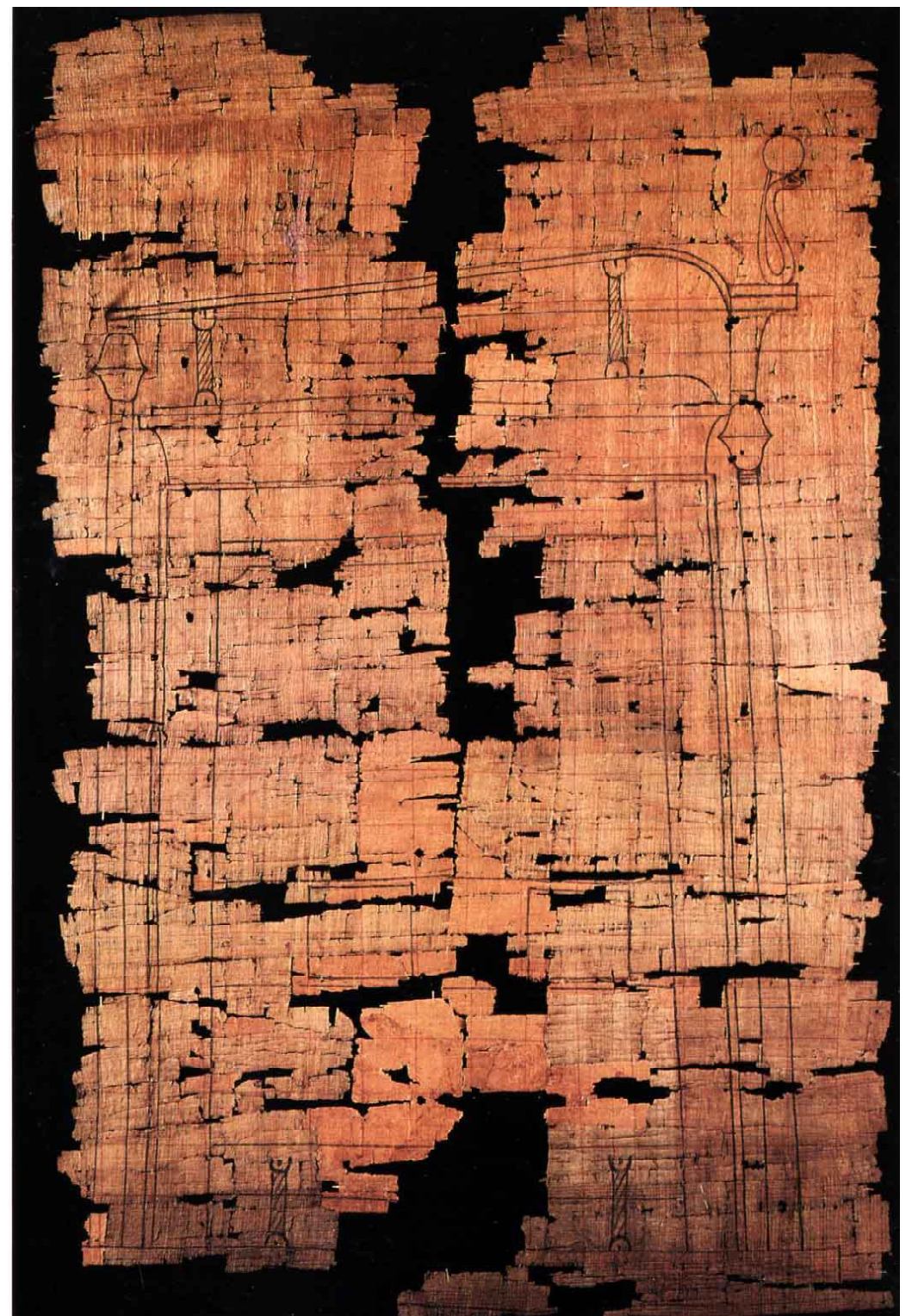

juntos, seguindo o único documento que se conhece sobre a arquitetura do período, a obra de Marcus Vitruvius Pollio, Dez Livros de Arquitetura, supostamente escrita no século I d.C. Em sua obra, Vitruvio refere-se às duas referências, escolhendo a melhor para exemplificar cada tipo de construção. Embora considerado como tal durante muitos anos, a obra de Vitruvio não se constrói especificamente como um tratado; nela, o autor procura estabelecer e descrever a função do arquiteto e o modo de se conceber e executar a arquitetura na Antiguidade. Alternando entre Grécia e Roma, seu legado nos deixou influências das duas civilizações, o que mais tarde, irá orientar
Figura 08 - Desenho lateral de Ghorab. (MILLON

LAMPUGNANI, 1994, p.20) a arquitetura e todos os estudos a ele referentes na Renascença, no período conhecido como Humanismo.

Arquiteto da Antiguidade que será melhor apresentado durante o texto, devido a importância adquirida no Renascimento

${ }^{2}$ Medida de escala utilizada na época e que refere-se a 0,5236 $\mathrm{cm}$, segundo os estudos de Mario de Mendonça de Oliveira (2002)

Além da obra de Vitruvio $^{1}$, muitos são os relatos da prática da arquitetura na Grécia e Roma Antigas.

Quando se pretendeu fazer em 448 a.C. uma construção comemorativa na Acrópole de Atenas, pensou-se, inicialmente, em convocar Calícrates para seu projeto e construção, mas um dos membros do conselho (boule), propôs uma emenda no sentido de se fazer um concurso público do projeto e os desenhos'não menores do que um cúbito' deveriam ser expostos por do que um cubito' dez dias, para serem julgados pelo voto popular. (OLIVEIRA, 2002, p.88).
Dando continuidade aos tipos de suportes encontrados na Mesopotâmia e no Egito, os desenhos da Grécia e de Roma também se valeram de papiro, pergaminho, tabuletas pintadas ou enceradas, e lápides. Acredita-se que os desenhos de maior riqueza de detalhes fossem feitos em papiro, ainda em vantagem ao pergaminho, por causa de seu elevado custo. Há também indícios de desenhos em tabuletas de madeira, porém, com características de "croquis", já que o suporte rígido não era apto a receber traçados mais finos e precisos. No entanto, o que se tem de herança de desenho de representação está em lápide de mármore, compreensível devido a sua durabilidade, como é o caso da famosa "Forma Urbis Roma", de grandes dimensões, medindo no total 13 x 18,10m, onde foram cadastrados todos os edifícios principais de Roma, no

Figura 09 e 10 período de Sétimo Severo. Esse painel da planta cadastral de Roma estava montado em uma das paredes do "Fórum de Paz". Infelizmente, muitos de seus fragmentos estão 


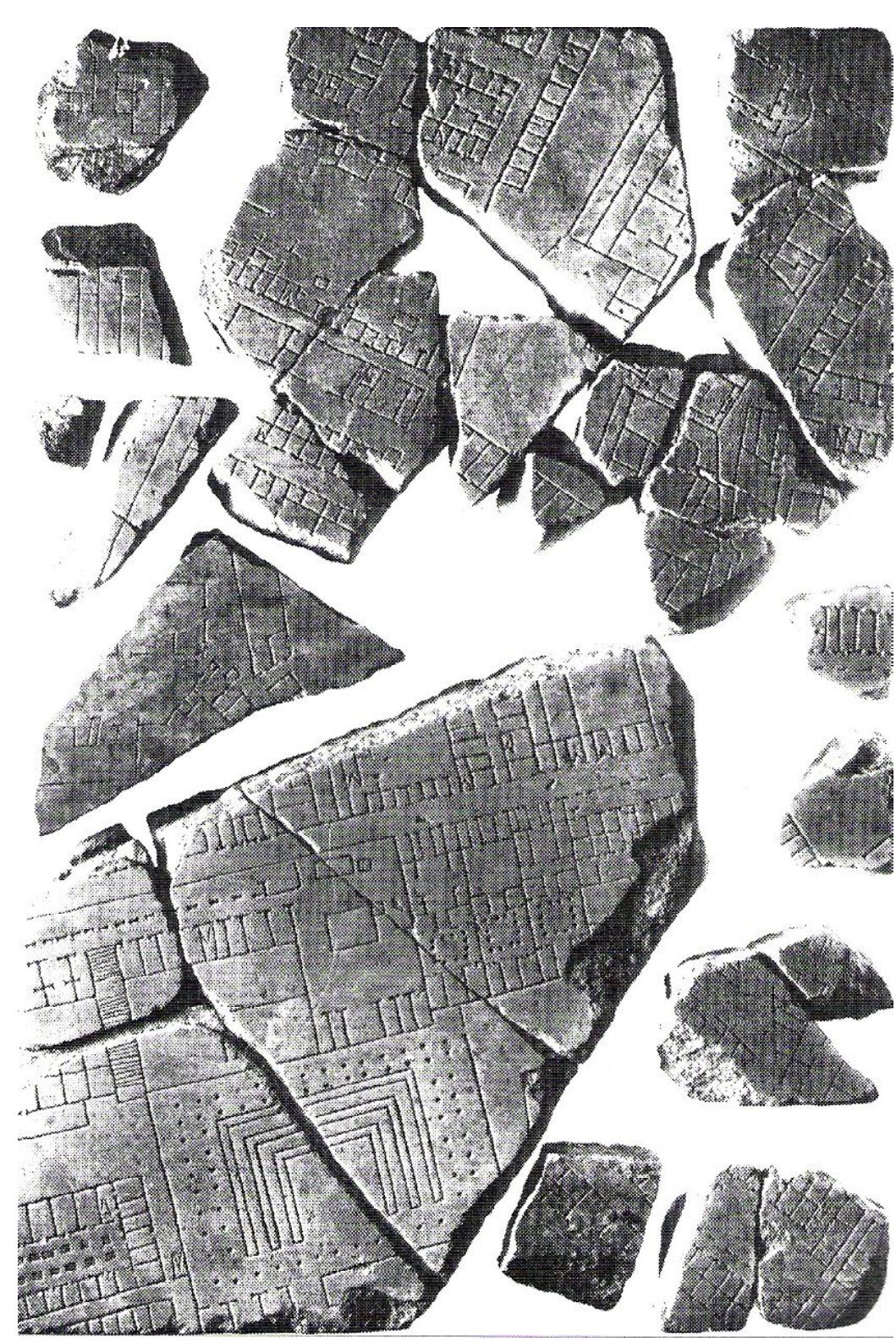

desaparecidos. Calcula-se que os fragmentos encontrados não ultrapassem um décimo da planta completa.

Vitruvio deixa claro nos Dez Livros de Arquitetura, entre outras premissas, a necessidade de domínio técnico na formação do arquiteto, indicando a importante presença do desenho na sociedade greco-romana. Com base nessa afirmação e nos documentos que chegaram até nós, pode-se dizer que os desenhos de representação para essas duas civilizações se apresentavam como: arquitetônico (tanto para contratação de profissional apto, como para a execução de
Figura 09 - Fragmentos da "Forma Urbis Roma". (OLIVEIRA, 2002, p.202).
Figura 10 - Fragmentos da "Forma Urbis Roma". (OLIVEIRA, 2002, p.203).

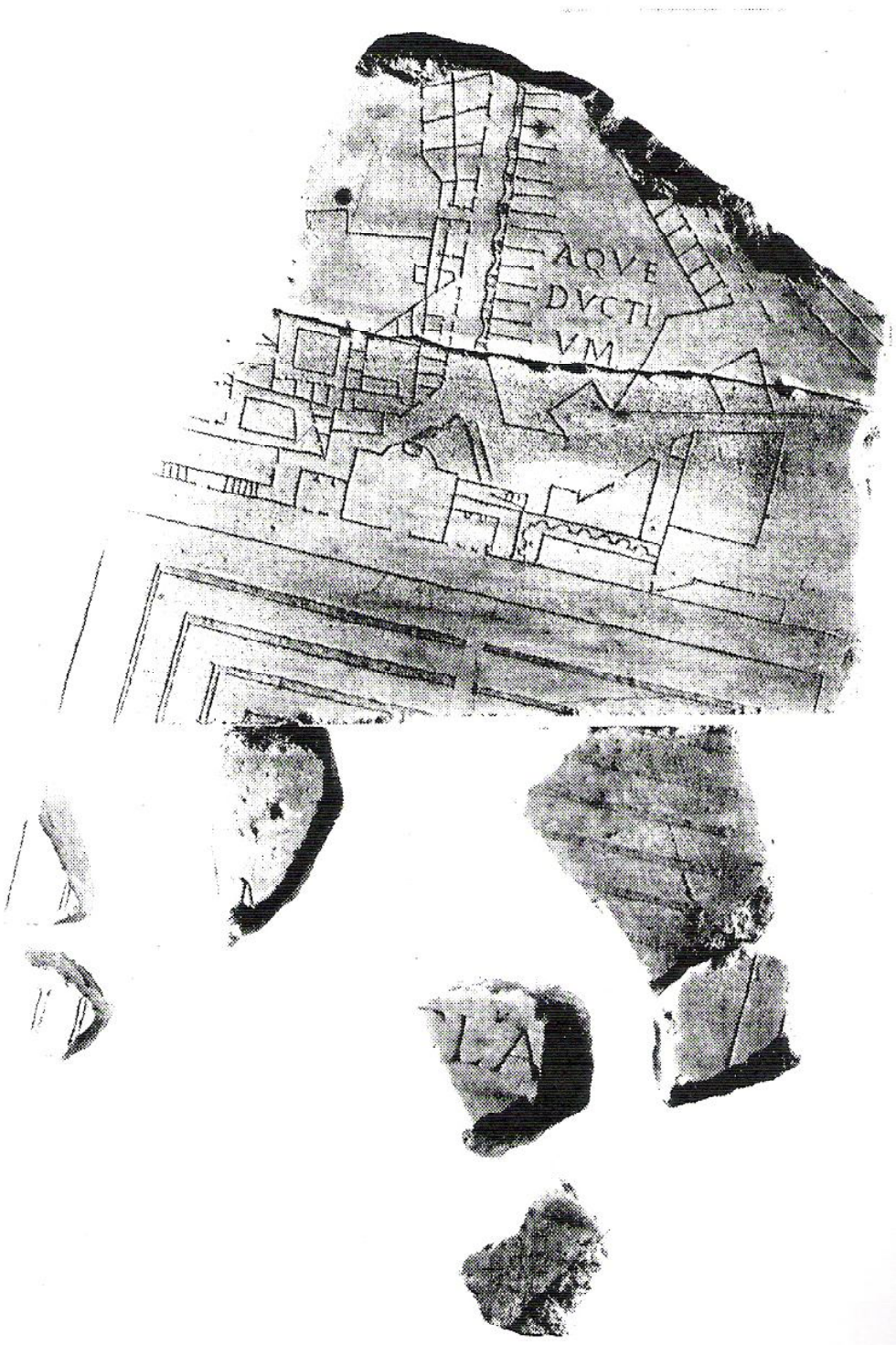

edifícios); de documentação - cadastro; decorativo; de cartografia (muito presente nas civilizações antigas); gráficos auxiliares e desenhos de máquinas e instrumentos (engenhosidades gerais e militares).

Um outro exemplo de desenho de representação que resistiu ao tempo é a planta apresentada na pedra tumular, atualmente no Museu de Perúgia. É um exemplar que demonstra a grande habilidade técnica de seu projetista, com cotas em algarismos romanos e talvez três andares ou pisos Figura 11 diferenciados, cada qual desenhado em escala diferente. 


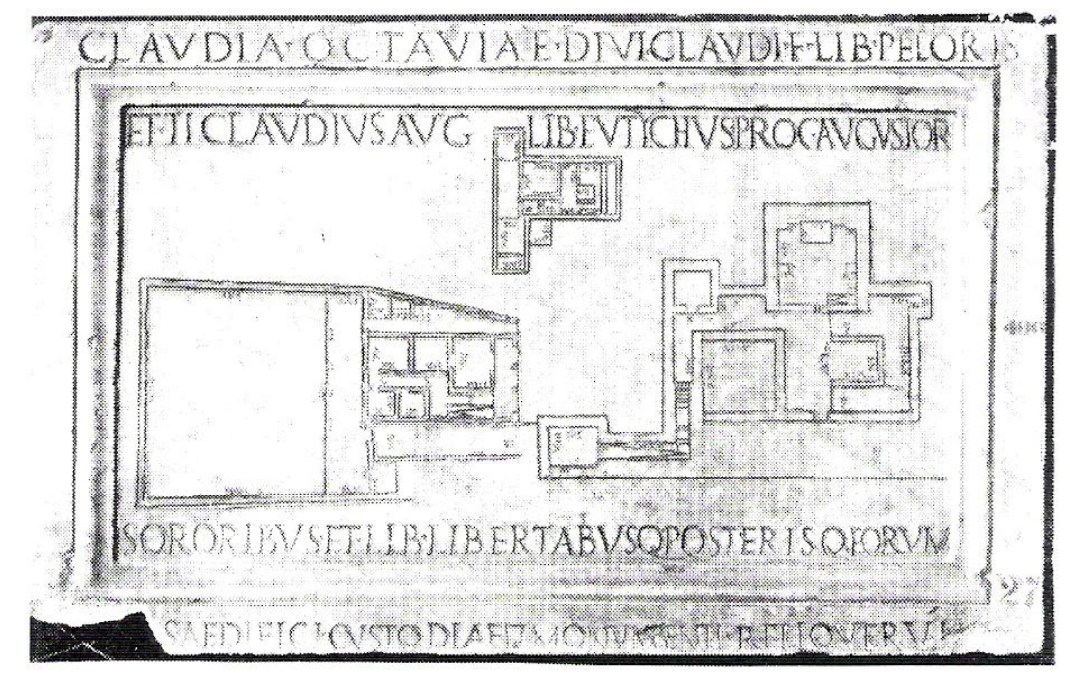

Figura 11 - Pedra tumular. Museu de Perúgia. (OLIVEIRA, 2002, p.204)

de arquitetura proposta. É difícil prever qual foi o antecessor, os instrumentos de representação possibilitaram a execução de determinada arquitetura ou o contrário? Talvez ambos se relacionem sem nenhuma pretensão de vantagem, a necessidade cria o instrumento, mas o instrumento também possibilita novas criações. Como em outras civilizações antigas, o desenho greco-romano também se consolidou através de estiletes, pincéis, penas de cana e até penas metálicas (em bronze, comum entre os romanos), compassos, réguas e esquadros, entre outros. Os mais interessantes são os compassos de redução ou ampliação, com proporção fixa de 1:2 "ou as escalas de um pé de comprimento divididas em quatro palmos e dezesseis dedos" (OLIVEIRA, 2002, p.105).

A escala e a modulação são características dos desenhos de representação na Antiguidade. Embora na Grécia faltem provas demonstrativas sobre esse processo de apresentação, pode-se também considerar que a prática da coordenação modular partiu do desenho para a arquitetura, também sempre pautada nas medidas humanas, ou seja, um sistema antropométrico. Também como as outras civilizações antigas, os desenhos de Grécia e Roma também se construíam através das projeções ortogonais (inclusive descritas na obra de
Vitruvio, e que veremos posteriormente).

Um assunto bastante estudado e ainda sob grandes indagações é o uso da perspectiva na representação artística e principalmente arquitetônica. A própria definição de perspectiva é difícil, pois está vinculada ao entendimento de cada período que pretende utilizá-la. Assim como sugere Mário Mendonça de Oliveira, a definição do termo em latim

$$
\begin{aligned}
& \text { (...) significa ver através de ou mesmo ver } \\
& \text { claramente. A própria significação etimológica } \\
& \text { da palavra, como se vê, admite uma semântica } \\
& \text { deveras elástica e é por isto que a perspectiva } \\
& \text { sensu lato confunde-se ou pode ser confundida, } \\
& \text { como toda forma de indicação de profundidade } \\
& \text { na representação bidimensional. (OLIVEIRA, } \\
& \text { 2002, p.111). }
\end{aligned}
$$

Embora os gregos e romanos não utilizassem a perspectiva como a conhecemos hoje, a indicação de profundidade fazia-se presente nas linhas de fugas de seus desenhos, mesmo não representando um ponto de vista unificado. No momento, limitar-nos-emos a considerar a perspectiva grega e romana como uma correção ótica sofrida pelo desenho, para se aproximar da visualização mais fiel do pretendido edifício. Ainda que no decorrer do texto a perspectiva apareça em cada momento da história, julgamos necessário apresentar algumas considerações sobre esse tema, no capítulo três, quando abordaremos algumas discussões sobre as teorias desenvolvidas no Renascimento, inclusive sobre as principais alterações entre a perspectiva "medieval e renascentista".

OMundo Medieval aparece para nós como um período 
diferente do que apresentamos até agora, tanto pela quantidade de desenhos descobertos da época, quanto pelos tipos de desenhos de representação que se julga freqüentes na profissão do arquiteto medieval. No entanto, o material iconográfico é abundante a partir do século XI. Anterior a esse momento, são raras as representações documentadas.

As bases utilizadas para os desenhos eram as mesmas presentes nas civilizações do período anterior. Contudo, há uma mudança interessante na Idade Média: tanto o terreno quanto as paredes também serviam como suporte para o desenho. Era uma espécie de desenho em escala real, onde o arquiteto representava seu projeto no local que deveria ser realizado. Esse pode ser um dos motivos da ausência de desenhos resultantes do início do Mundo Medieval. Pode-se destacar também o alto custo de pergaminho, grande entrave da representação até então; e ainda "a manutenção do sigilo sobre os processos de traçados que permitiam a passagem da planta à elevação e outros procedimentos não divulgáveis no exercício da profissão do arquiteto" (OLIVEIRA, 2002, p.131), como um segredo pertencente aos homens cultos. Assim, supõe-se que a comunicação do desenho entre arquitetos e construtores era feita oralmente ou através de algum modelo ou objeto.

A partir da necessidade de representar edifícios mais complexos, de diferentes soluções, e ainda com maior disponibilidade de pergaminho, os desenhos de arquitetura tornaram-se mais numerosos.

Também como nas civilizações antigas, o arquiteto medieval deveria ter uma formação de homem culto, com grande desenvolvimento técnico de suas habilidades em
Figura 12 - Monastério de St. Gallen (SAINZ, 1994, p.78)

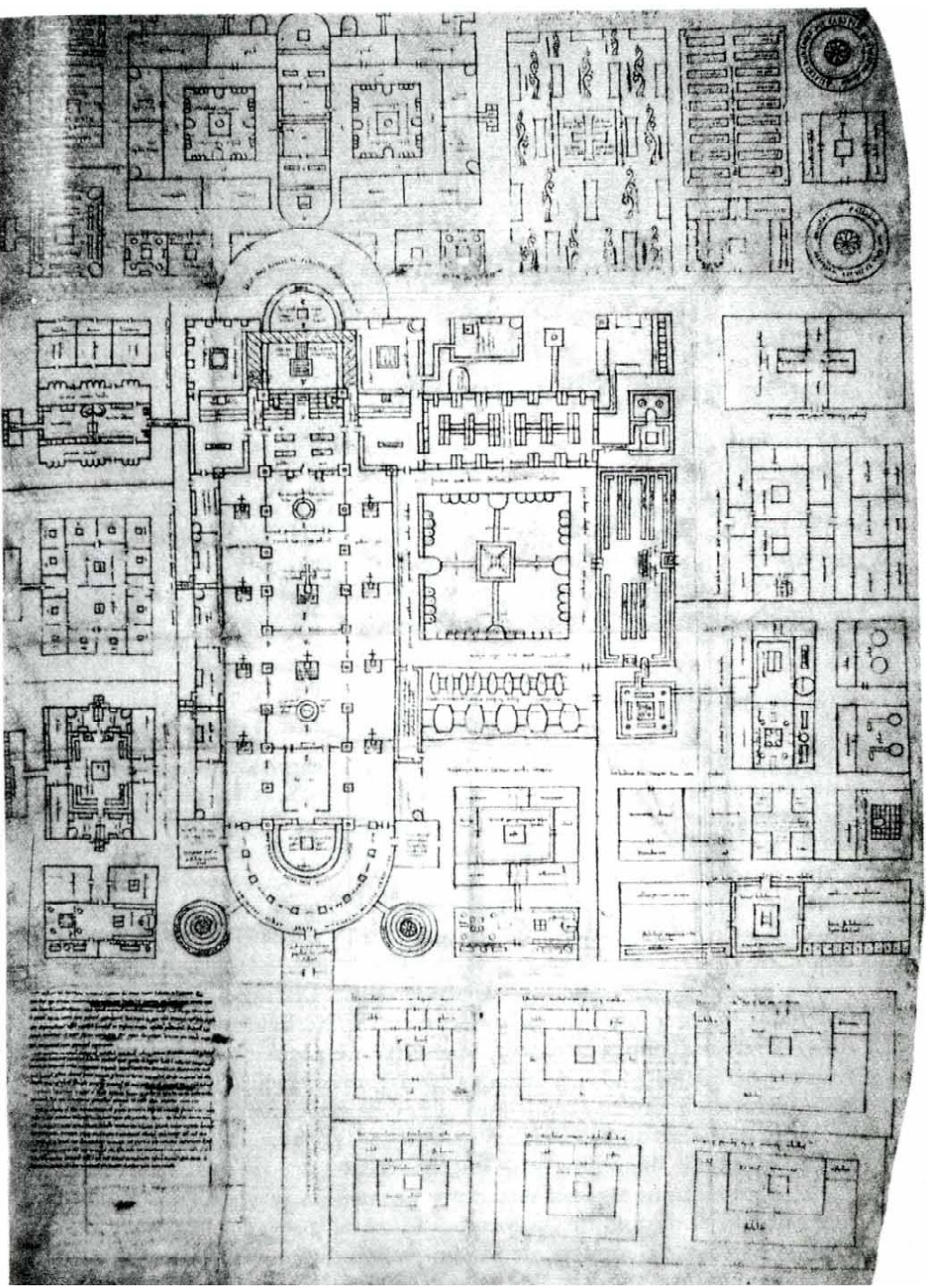

representação gráfica, principalmente em relação aos ensinamentos de procedimentos geométricos para organização de seus traçados.

Apesar da arquitetura aparecer como tema em diversas pinturas, o primeiro desenho de arquitetura, representando um projeto como algo que se pretende construir, é a planta do

Figura 12 monastério de St. Gallen na Suíça, de 820, século IX. Essa planta é um esquema. Nela estão representadas todas as divisões dos espaços através de linhas, sem diferenciar em muitos lugares as espessuras das paredes. O que torna essa representação curiosa é o uso de nomes e mobiliário para rotular os ambientes, tal como são representados nos projetos 
atualmente. Esse esquema parece um modelo que serviria também para a construção de novos mosteiros. Talvez por isso, não houvesse cortes e elevações. Cada novo projeto poderia adotar suas alturas, materiais e técnicas construtivas da melhor forma possível, segundo os costumes de construir na Alta Idade Média.

Sainz, como alguns outros pesquisadores, afirma que,

As representações de temas arquitetônicos anteriores à planta de St. Gallen não podem ser consideradas autênticos desenhos de arquitetura. A verdadeira história do sistema gráfico arquitenico não teminílo antes de 820 gráfico arquetonico nao teminicio antes de 820 deixando de fora as grandes culturas antigas e boa parte da arquitetura medieval. Depois deste, os seguintes desenhos conservados já são praticamente do século XIII; com isso, os séculos intermediários também não podem ser considerados em termos de comparaça o entre arquitetura e sua representação gráfica. (SAINZ, 1990, p.199).

Portanto, além dessa “única” comprovação do desenho como instrumento de projeto, outros desenhos realizados na Idade Média podem ser classificados como: desenhos de apresentação para clientes; concursos; como cadastros; esboços de elementos exemplares; caderno de estudos; engenhos, principalmente militares; detalhes; etc. Os mais numerosos eram os desenhos para clientes ou mesmo concursos, os quais eram feitos normalmente em tinta preta sobre pergaminho.

Os primeiros projetos representados com o sistema mais próximo ao atualmente empregado datam do século XIII, e se referem a loggias medievais de catedrais góticas. Eram retratadas elevações muito elaboradas se comparadas às

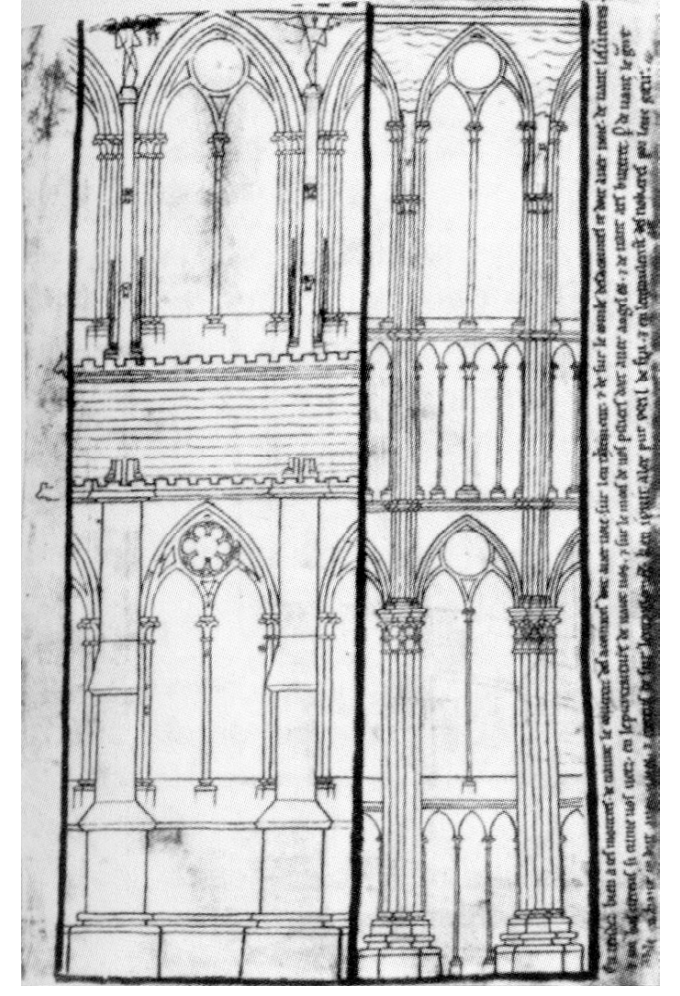

onnecourt, interior do co da catedral de Reims, 1230 (ACKERMAN, 2003, p.35).

plantas, e os desenhos em planta de edifícios completos eram mais escassos. Enquanto na Alta Idade Média, para os construtores era suficiente uma planta simples, esquemática, que em geral já correspondia a um tipo de elevação definido, no século XIII, os construtores góticos começaram a realizar ${ }^{3}$ Arquiteto francês da Idade Média, que realizou um desenhos muito detalhados e de muita qualidade. caderno de desenhos - Álbum de Villard de Honnecourt referentes às suas duas áreas de interesse: Escultura Arquitetura. Nesse caderno Honnecourt ${ }^{3}$, datados de início do século XIII, podem ser encontram-se algumas considerados um marco inicial para a convencionalização do ilustrações animais edeconstruçōes, todas desenho de arquitetura. Seus desenhos podem ser inseridas em esquemas geométricos, como uma considerados cadastrais e de estudos, feitos de maneira ntativa de facilitar sua representação. Segundo informal, sobre suas viagens pelos diversos canteiros da Wittkower (1989), Honnecour parecia desenhar a partir da Europa Medieval. observação de esculturas.

No álbum de Villard de Honnecourt está retratado em um desenho único, a elevação e o corte de uma arcada do coro Figura 13 da catedral de Reims, separados apenas por uma linha vertical, porém mantendo uma correspondência entre si; um 
tipo de representação que mais tarde será muito utilizado pelos renascentistas italianos.

Antes da invenção e difusão do papel, ocorrida no século XIV, os arquitetos tinham dificuldades para desenvolver suas idéias a partir de esboços, ou mesmo para registrar suas concepções projetuais. Até o aparecimento do papel, o pergaminho servia como um plano para os registros gráficos, porém, eram muito difíceis de preparar, e, portanto, de custo alto para o uso comum. Por isso, poucos foram os desenhos sobre pergaminho que sobreviveram, como é o caso, de uma série de desenhos para a catedral de Reims, os quais parecem ter sido realizados sobre várias camadas de uma mesma folha, através de uma raspagem parcial dos anteriores.

O álbum de imagens de Villard de Honnecourt tratase de um livro originalmente de 63 páginas, porém oito se perderam no tempo. Seu conteúdo refere-se à construção arquitetônica e mecânica, dimensionamentos, levantamentos e também a escultura arquitetônica. Os textos que acompanham os desenhos sugerem que o volume era uma tentativa de construir um manual de instruções, útil mais a leigos interessados em maquinarias, do que a artesãos e projetistas.

O desenho em elevação e corte apresentado é o único exemplar desse tipo de representação presente no álbum. Ackerman (2003) sugere que Villard de Honnecourt tenha seguido essa forma de representação de algum projetista da própria catedral, por causa da suposta deformação que o desenho tenha sofrido, para ser encaixado na folha. Além disso, a catedral não tinha sido totalmente erguida no período da visita de Villard de Honnecourt.
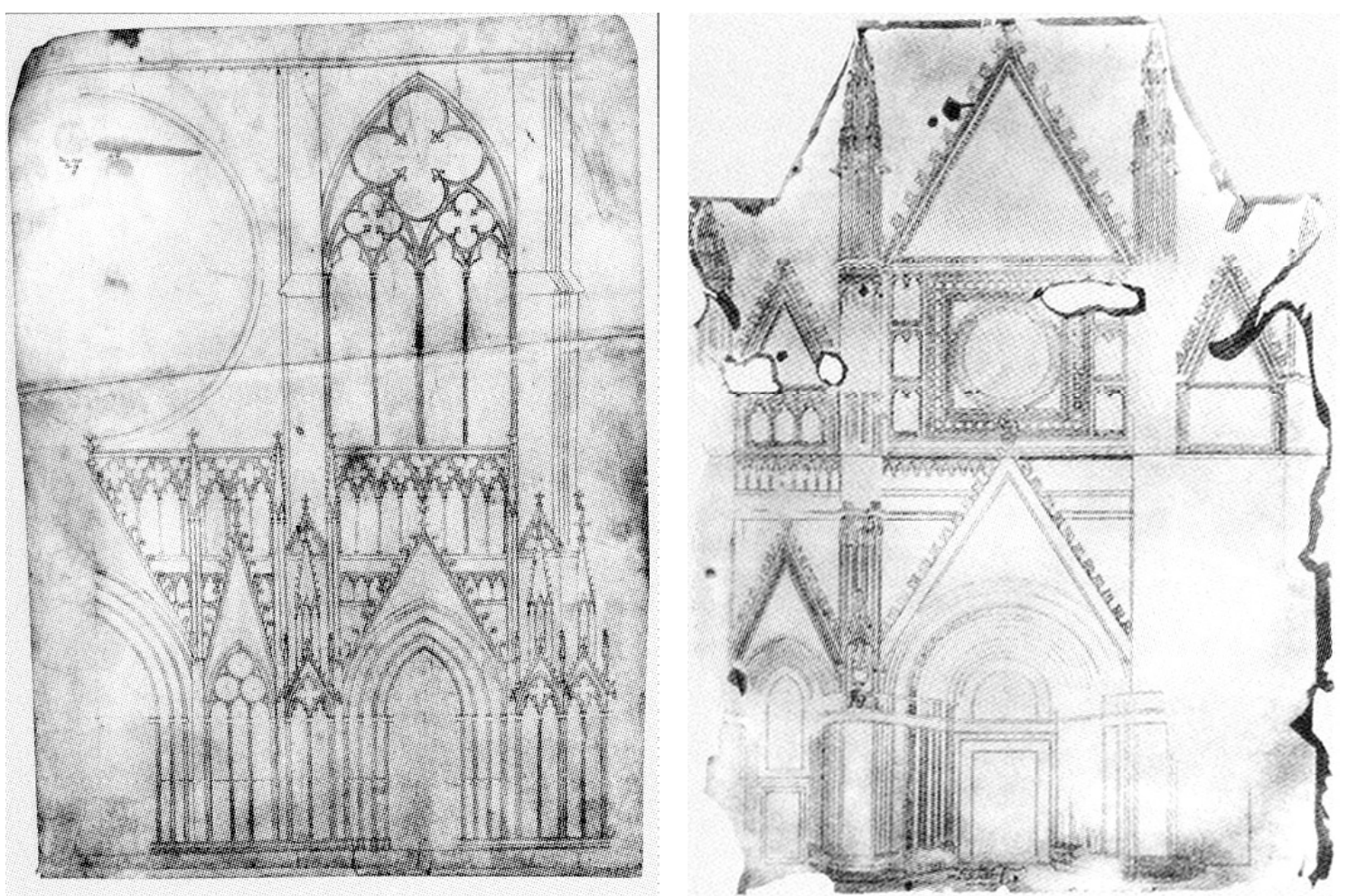

Figura 14 (acima) - Elevação da fachada da catedral de

No século seguinte aos desenhos da catedral de Reims, Strasburgo, século XIV. os mestres góticos criaram uma técnica elegante e mais atua (ACKERMAN, 2003, p.41).

Figura 15 (direita acima) - Propara representar as elevações arquitetônicas, próprias para eto para a fachada de Orvieto, descrever os detalhes mais complicados e as variações de nível 1320. (ACKERMAN, 2003, mais complexas. O exemplo mais notável é constituído por p.43). uma série de desenhos sobre pergaminhos da fachada da

Figura 14 catedral de Strasburgo, datados da década de 30 do século XIV. Nenhum desenho do gênero foi feito na Itália. O desenho da elevação do campanário da catedral de Florença, de 1334, mostra diversos elementos representados em uma perspectiva subjetiva. Para exemplificar, nesse desenho, os consoles que sustentam a cornija na passagem da base quadrada ao piso octogonal estão inclinados para a esquerda sobre o lado esquerdo e à direita sobre o lado direito, criando um efeito de perspectiva. O desenho da elevação da fachada para a catedral

Figura 15 de Orvieto, executado em 1320, mostra elementos perspectivos ainda mais enfatizados no portal de entrada e nas torres.

Na Europa Setentrional, o Gótico substituiu a solidez 


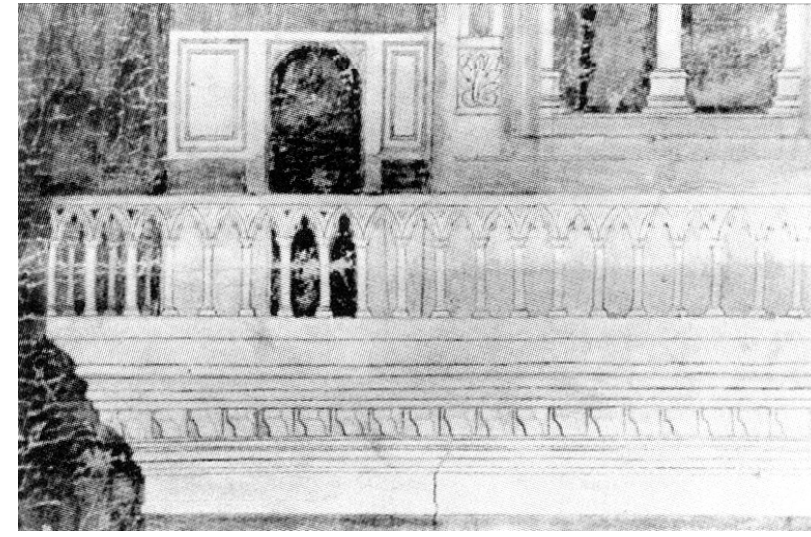

Figura 16 (direita) - Giotto (?), projeto para o campanário da catedral de Florença, elevação, século XIV. (ACKERMAN, 2003, p.44).

Figura 17 (esquerda) - Detalhe do projeto de Giotto ença. (ACKERMAI p.42)

do Românico com uma estrutura e uma expressão sempre mais essenciais, que se prestavam a uma imagem gráfica linear e ortogonal. A utilização da representação em perspectiva e do claro-escuro para recriar a profundidade foi muito mal empregada na apresentação de edifícios góticos. Os grandes desenhos das elevações da catedral de Strasburgo demonstram o refinamento da representação ortogonal. Para estes projetos do tardo gótico, com seus elementos superficiais admiravelmente sutis, esta técnica parecia inevitável.

Na mesma época, entretanto, os arquitetos italianos perseguiam objetivos completamente diversos, como exemplificam os desenhos do projeto para a fachada da catedral de Orvieto, onde se pode observar em uma cópia, feita a mão livre, do fim do século. O famoso desenho atribuído a Giotto para o campanário de Florença pode ser indicado como o primeiro desenho ortogonal realizado na Itália, mesmo que, ao representar os consoles sobre as cornijas e balaustrada dos balcões, o seu autor não tenha resistido à sugestão da profundidade.

Segundo Henri Focillon em um estudo, essas diferenças são compreensíveis porque em cada época e em cada lugar dominava uma forma artística: no norte da Europa tratava-se de arquitetura, enquanto na Europa meridional era a pintura.

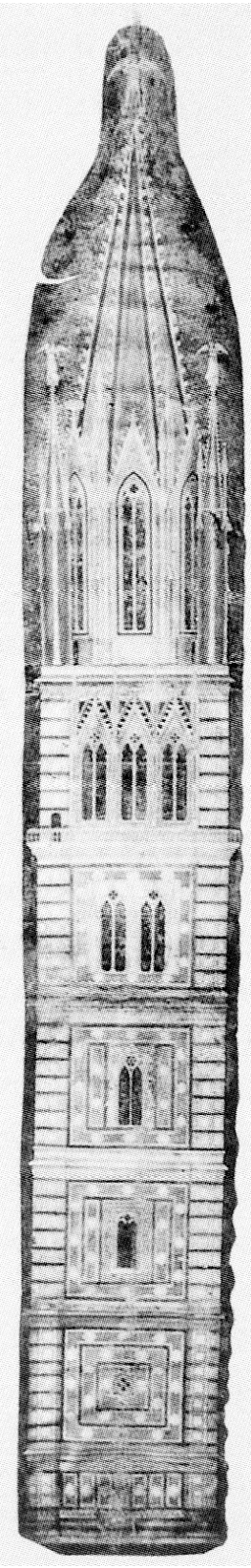

Figura 18 - Antonio di Vicenzo, planta e corte parcial da nave da catedral de Milão, 1390 (cópia moderna). (ACKERMAN, 2003, p.46).

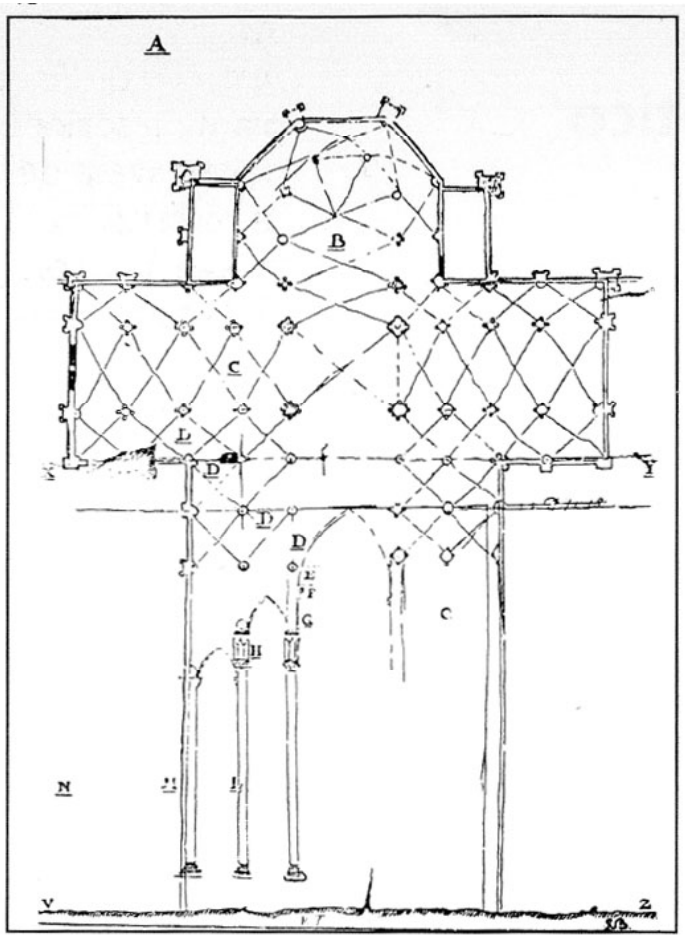

Os mestres do norte formavam-se em oficinas de construtores, enquanto os italianos iniciavam como pintores ou escultores.

Um desenho realizado em 1390, de autoria de Antonio da Vincenza, referente a catedral de Milão, apresenta Figura 18 simultaneamente as diferentes técnicas de representação italiana e nórdica na construção arquitetônica. Nesse desenho em corte, nota-se a representação em perspectiva dos capitéis e bases das colunas, ainda que a planta esteja construída logo acima, servindo como guia para a elaboração desse corte.

Alguns anos depois à realização desse desenho, o Renascimento italiano começou a se impor sobre a tradição gráfica do Gótico norte-europeu. Mesmo que os desenhos nórdicos do século XV ainda conservados evidenciem a representação das estruturas em estilo gótico, pode-se notar que o estilo gráfico italiano começou a influenciá-los com seu impulso pictórico ou perspéctico, como mostra o Musterbuch 


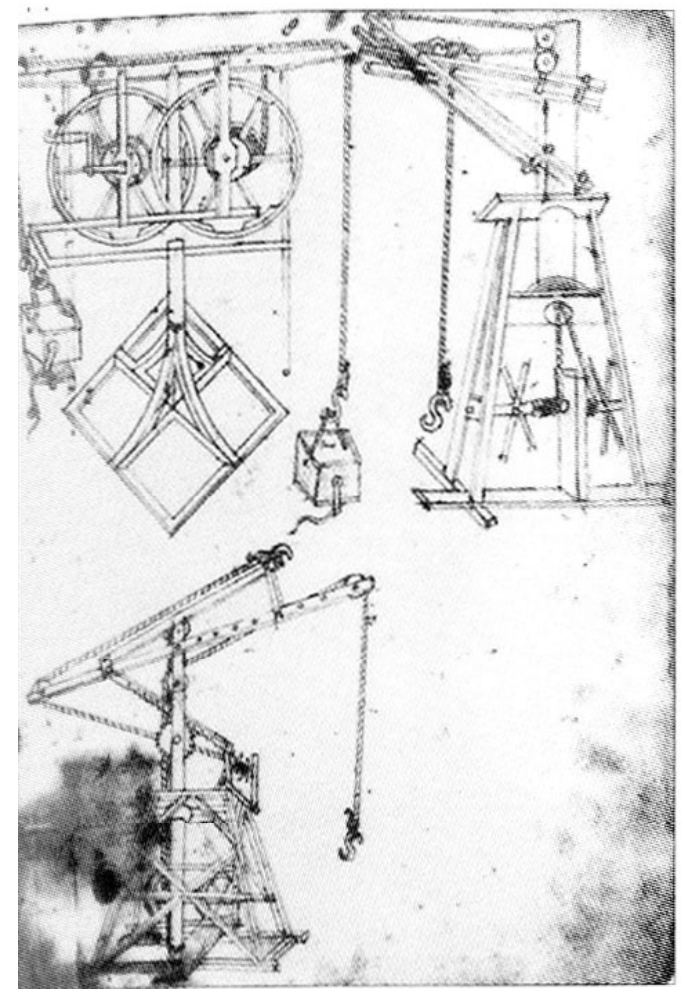

de Hans Hammer, proveniente da biblioteca de Wolfenbüttel e compilado no fim do século XV.

Segundo Ackerman (2003), entre as outras 33 folhas desse livro, que representam "máquinas para construção", esse documento torna-se especial por apresentar uma característica bastante interessante sobre a incorporação do desenho pictórico italiano na representação freqüentemente ortogonal gótica do norte europeu. O uso da perspectiva, tal como Brunelleschi fazia para representar também suas "máquinas de construção", tornou-se muito importante na representação de algo tão minucioso que só com as projeções ortogonais não seria facilmente compreendido. Para isso, serviu-se de um tipo de "modelo gráfico", a axonometria.

Embora seja possível encontrar ocasionalmente exemplos de um detalhe em perspectiva ou com sombra para sugerir a profundidade em um desenho do tardo gótico no norte da Europa, isto não anula a representação fundamentalmente ortogonal que caracteriza aquele estilo.
Aqui a passagem de um para o outro é documentada em uma só folha. Deste momento em diante, o desenho de arquitetura do norte da Europa será progressivamente invadido pela perspectiva pictórica italiana.

No século $\mathrm{XV}$, enquanto o Gótico era suprimido pelo retorno à arquitetura à antiga, a concepção da perspectiva dos arquitetos italianos permanece fundamentalmente a mesma: ressaltos e recuos não vinham representados com a projeção geométrica da perspectiva "artificialis", mas ainda à maneira medieval. Ainda que os arquitetos nórdicos necessitassem de desenhos exatos e precisos para representar seus projetos (máquinas, arquitetura, topografia, cartografia), a perspectiva dos italianos começou a permear esses desenhos, de forte tradição em projeções ortogonais.

A predileção medieval italiana pelo desenho em perspectiva foi consolidada no século XV (Quattrocento) através da interpretação feita de um texto que por todo o Renascimento foi considerado a máxima autoridade: o texto de Vitruvio conhecido durante toda Idade Média, mas que sofreu algumas revisões ao longo do tempo. $\mathrm{O}$ tratado do arquiteto romano Marcus Vitruvius Pollione, De Architectura, escrito no séc. I a.C, apresenta uma primeira referência escrita sobre a forma de representar um edifício sobre uma superfície. Considerado uma compilação de um saber arquitetônico presente da Grécia e Roma Antiga, o tratado de Vitruvio caracteriza um sistema de projeção geométrica para representação, atribuído aos ensinamentos gregos. Esse sistema aparece em um dos princípios universais de arquitetura, propostos por Vitruvio, a dispositio, que pode ser definida como a colocação adequada dos elementos na obra (concordância), e a elegante execução do edifício nas várias 
composições para alcançar a qualidade.

As figuras da dispositio são três, icnografia, ortografia, scenografia, ou seja, planta, elevação e desenho em perspectiva. A icnografia consiste no justo uso do compasso e da régua e apresenta o desenho das formas sobre o plano. A ortografia é a imagem da fachada, e da obra futura desenhada segundo as proporções. A scenografia é o esboço da fachada e dos lados vistos em ângulo, com a convergência de todas as linhas ao centro do compasso. (FERRI, 2002, p.115)

Pode-se ressaltar ainda o incentivo que Vitruvio faz ao uso de perspectivas, mesmo que essa só tenha sido utilizada em arquitetura a partir do século $\mathrm{XV}$, quando os arquitetos começaram a vê-la como um instrumento necessário para "visualizar e controlar tridimensionalmente os seus projetos, e também torná-los compreensíveis aos clientes, que freqüentemente ficavam confusos com as abstrações das convenções analisadas". (ACKERMAN, 2003, p.252). No entanto, alguns arquitetos do Renascimento não concordavam com Vitruvio. A representação em arquitetura não poderia usar a perspectiva porque nesse tipo de desenho poderia acarretar uma ilusão (nesse caso, um engano) da obra proposta. Esse pensamento era defendido por Alberti - tratadista renascentista que teorizou a pintura, arquitetura e escultura. Essa é a razão pela qual esse estudioso do Renascimento fez distinção entre instrumentos do arquiteto e do pintor para alcançar a magnitude de suas respectivas obras.

Não há indícios de textos que comprovem uma sistematização no uso do desenho em arquitetura nos períodos após Vitruvio até Alberti. Portanto, tudo que se sabe sobre sistemas de representação anteriores ao século XV acabaram sendo deduções feitas sobre as imagens conservadas.

O período que inicia a construção de uma teoria de representação gráfica é o Renascimento. O tratado de Leon Battista Alberti, De re aedificatoria, de 1485 diferenciou didaticamente o conceito de desenho e de construção. Em sua concepção, o desenho traduzia-se como um conjunto de operações estabelecidas pela mente humana, como desígnio, desejo, antes mesmo de ser um conjunto de linhas traçadas sobre um pedaço de papel. Não se trata de algo imaterial, mas de uma forma exata estabelecida antes mesmo de ser concretizada em forma de linhas e ângulos sobre um plano. $\mathrm{O}$ desenho para Alberti pode ser traduzido em um símbolo que transmite as idéias do arquiteto, ou seja, é apenas um meio adequado para uma possível realização física posterior.

Alberti estabeleceu uma nítida diferença entre o uso do desenho para um arquiteto e para um pintor:

Há uma diferença entre o desenho de um pintor e o de um arquiteto: aquele se esforça em dar relevo ao quadro por meio de sombras, linha ângulos agudos; o arquiteto, com seu desprezo ângulos agudos; o arquiteto, com seu desprezo
pelas sombras, representa o relevo por meio do desenho da planta, e os espaços e as formas de cada elevação os mostra em separado mediante linhas invariáveis e ângulos verdadeiros, como alguém que não quer que sua obra seja julgada por impressões visuais, e sim refletida por por impressões visuais, e sim refletida por
dimensões determinadas e racionais. (JAVIER, 1991, p.95).

Alberti criticava os princípios então prevalecentes entre os arquitetos italianos de representar em perspectiva alguns elementos elevados ou rebaixados de um edifício, já que a 
perspectiva utilizada não era a de projeções geométricas, e sim subjetiva e variável. Por isso, a teoria e a prática da perspectiva aparecem em seu livro De pictura, dedicado à arte da pintura.

Para Alberti, a característica mais importante do desenho de arquitetura era sua veracidade. Sua distinção entre os desenhos de pintores e arquitetos procurava apresentar um sistema de representação em arquitetura, usando a planta, composta por linhas, para refletir o edifício tal como deveria ser e não como deveria ser visto.

Alberti foi o primeiro a opor-se ao uso da perspectiva ou do claro-escuro para recriar a profundidade, já que o uso desses artifícios eram técnicas pictóricas, portanto, contrárias às exigências da construção arquitetônica. Segundo Alberti, para assegurar a clareza do desenho de um edifício existente ou futuro, os arquitetos deveriam usar somente desenhos nos quais todas as suas partes (que se distanciam ou que avançam) fossem projetadas sobre um plano, ou seja, o que se conhece hoje como projeções ortogonais. Porém, esse sistema de representação não se mostrava verdadeiro nos desenhos onde os elementos mais próximos ao observador apareciam maiores daqueles mais distantes, ou ainda, os elementos circulares em suas bases e capitéis viessem desenhados como curvilíneos, o que eram muito comum naquele momento. Grande parte dos desenhistas do século XV ignorou as indicações de Alberti. As elevações desenhadas pelos arquitetos dos primeiros vinte anos do século XVI continham elementos em perspectiva, e as vistas em perspectiva subjetiva eram comuns.

Pode-se dizer que, a partir do tratado de Alberti, De Pictura, onde foi considerada perspectiva pictórica, começou

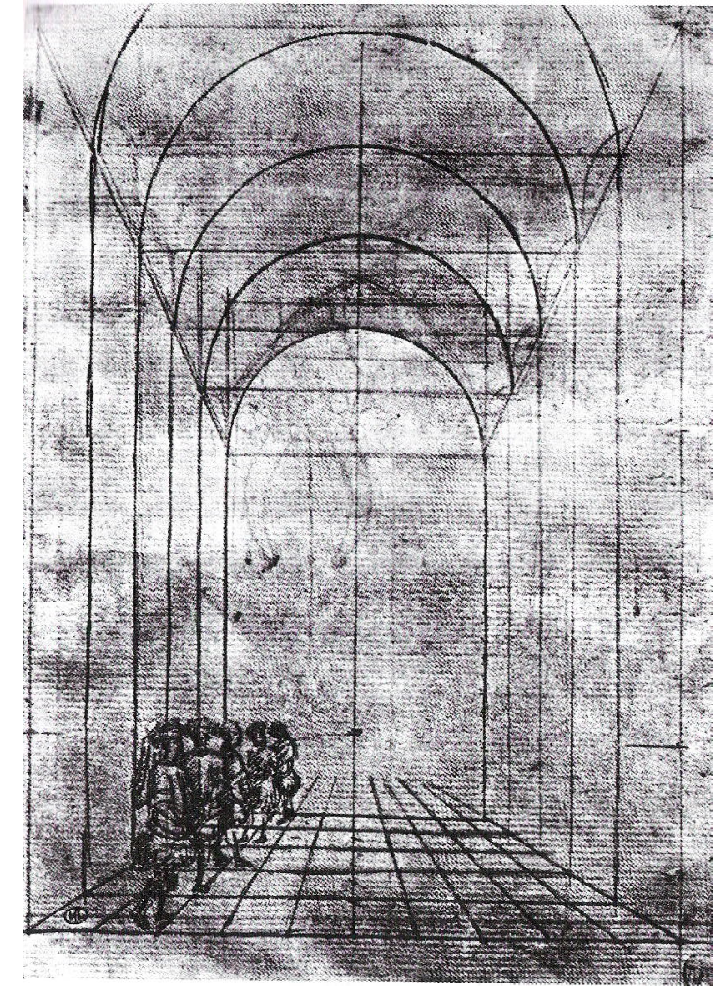

Figura 20 - Pisanello, primeirior com figuras; perspectiva. (LOTZ, 1985, p.42).

a aparecer representações de caráter arquitetônico em perspectiva. O primeiro desenho desse tipo, que retrata o interior de um edifício, é atribuído a Pisanello, mas aqui não se define mais que a construção geométrica do espaço. Esse desenho mostra uma sala coberta com abóbada de canhão, e

Figura 20 algumas figuras humanas. "O desenho de Pisanello mostra claramente as vantagens que oferece este método para estabelecer a escala e a colocação das figuras dentro de um espaço definido arquitetonicamente". (LOTZ, 1985, p. 05).

Foi graças a Bramante (com formação de pintor antes de arquiteto) que se disseminou o uso de perspectivas. A ele, deve-se o desenvolvimento do corte em perspectiva, uma combinação de corte e visão interior (perspectivada) do edifício projetado.

A perspectiva desenvolvida pelos arquitetos apresentava diferente linha do horizonte em relação à da pintura. Enquanto para os pintores, a linha do horizonte era na altura do olhar do observador, defendido por Alberti no tratado, para os arquitetos o ponto de vista se situava bem 
acima, na tentativa de distorcer o menos possível a perspectiva e garantir o entendimento da planta, através do desenho. Pode-se dizer que havia uma tentativa de criar uma perspectiva geométrica, propriamente arquitetônica.

A qualidade da perspectiva é seu caráter visual, ou seja, sua semelhança com a imagem que se forma na retina. Essa característica, antes do Renascimento, fazia com que ela se beneficiasse somente de leis visuais, e que, portanto, não continha nenhuma propriedade geométrica. A perspectiva, antes de sua teorização matemática, não garantia a justa visualização das dimensões de superfícies, nem de ângulos e não permitia a interpretação exata das proporções.

Por essa razão, Alberti incentivava claramente o uso da planta como documento gráfico para a arquitetura e deixava as representações de caráter visual ou ilusório (a perspectiva) para os pintores. Para ele, a representação ideal em arquitetura se traduzia em três elementos: planta, corte e o modelo tridimensional, no qual poderia ser visto toda a relação métrica precisa e compositiva da obra que se pretendia realizar. Ainda nesse momento, nem todos conheciam a perspectiva como um meio preciso, geométrico, e, portanto, apenas acabavam utilizando-a para gerar uma visualização de como seria o espaço projetado. Por isso que Alberti tinha receio de indicar a perspectiva para os arquitetos. Esse elemento poderia, ainda, apresentar-se como um artifício enganoso na representação de um projeto.

A representação em planta significava uma continuação da tradição medieval, onde essa projeção horizontal era o único guia para o desenvolvimento de projetos. A partir da planta, poderiam ser deduzidas as elevações e cortes. Na Idade Média,

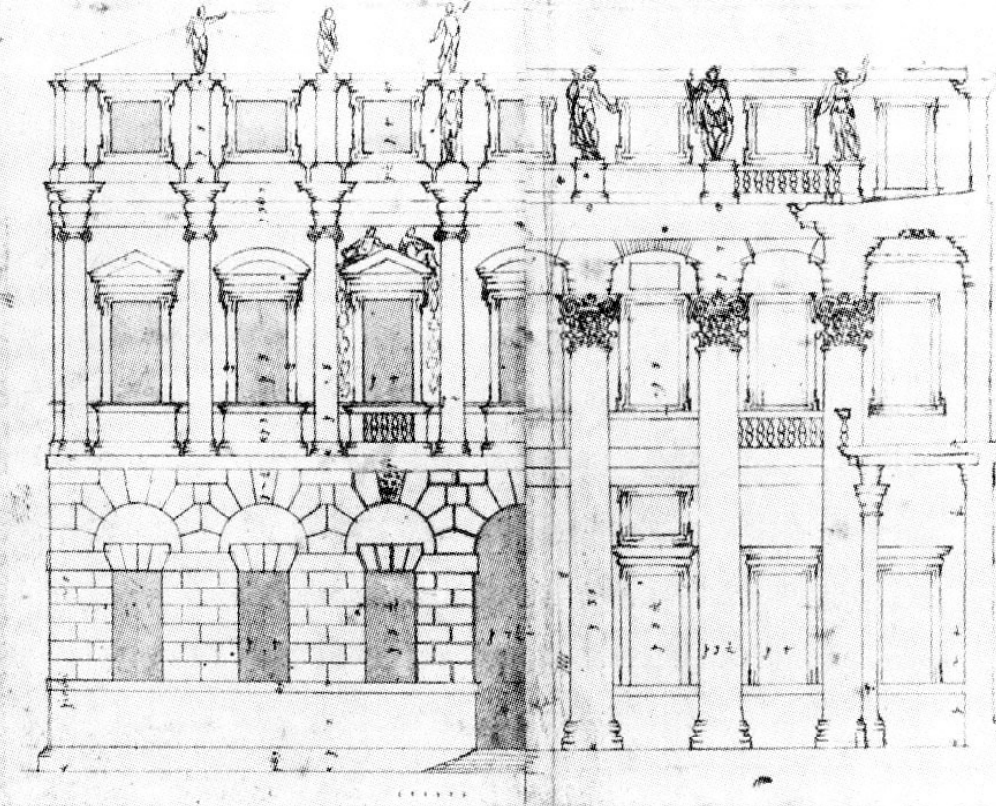

os procedimentos gráficos faziam parte da sabedoria de poucos, e sua violação poderia ser punida até com a morte.

Na Itália, apenas no século XVI, com Antonio da Sangallo, o Jovem, teve início essa busca pela veracidade da representação em arquitetura, "os primeiros [desenhos] capazes de satisfazer os desejos de Alberti" (ACKERMAN, 2003, p.30). Até então, todos os arquitetos ainda estavam impregnados pelo olhar do pintor, já que muitos deles também atuavam como tal.

Após Antonio da Sangallo, o Jovem, alguns outros arquitetos procuraram desenhar segundo projeções ortogonais, como Baldassarre Peruzzi e Andrea Palladio, que usavam esse sistema tanto para representar seus projetos, como os edifícios Figura 21 existentes.

Após o tratado de Alberti, o segundo momento em que se desenvolveu a teoria de uma representação gráfica em arquitetura, foi em 1519, com a carta de Raffaello Sanzio (14831520) ao papa León X. A carta de Rafael ao papa Leone X pode 
ser considerada dividida em duas partes. A primeira refere-se à lamentação de Rafael às condições de abandono que se encontram as ruínas dos antigos edifícios romanos, na qual aconselha o papado a fazer um levantamento de Roma, separando os edifícios construídos em três períodos considerados por Rafael: das construções antigas, da época dos godos e dos modernos, isto é, de seus contemporâneos. Na segunda parte, Rafael descreve cuidadosamente os métodos de levantamento dos edifícios, e segue definindo e pontuando o que se entenderia por planta, elevação e corte, finalizando com uma comparação entre esse sistema de projeções ortogonais e a perspectivas.

Abaixo é apresentado o trecho da carta que revela a descrição do sistema de projeção ortogonal na construção de um desenho de representação arquitetônica, entendido por Rafael, e muito provavelmente, utilizado por todos seus contemporâneos.

E porque o modo de desenhar que é mais apropriado ao arquiteto é diferente ao do pintor, assim direi por parecer mais conveniente para se entender todas as dimensões e saber encontrar todos os elementos dos edifícios sem erros. O desenho, portanto, dos edifícios pertinentes ao arquiteto se divide em três partes, das quais a primeira é a planta, ou-como dizem - o desenho plano; a segunda é a parede de fora ["parete di fuora" significaria atualmente a elevação], com seus ornamentos; e a terceira é a parede de dentro ["parete di dentro" seria o corte atualmente], também com seus ornamentos. A planta é a que reparte todo o espaço plano do lugar a edificar, ou - quero dizer - o desenho da fundação de todo o edifício, ao nível da terra. E o espaço, ainda que elevado, necessita ser reduzido ao plano, e fazer com que a linha da base da elevação posta em plano seja paralela a todos os pisos do edifício, (...) e sobre aquela caiam em prumo e em perpendicular todos os muros do edifício, e chama-se este desenho- como é dito - 'planta' (...).

Desenhada esteja a planta, compartimentada com seus membros, com as larguras desses, en círculo, ou em quadrado, ou a forma que seja deve-se construir abaixo, desenhando sempre desce constrit at largura da base de todo o edifício, e a partir do ponto central da base, deve-se construir uma outra linha reta a qual faça com uma extremidade e a outra, dois ângulos retos, e assim esta será a linha do meio do edifício. Das duas extremidades da linha da largura do edifício, constroem-se duas linhas paralelas e perpendiculares à linha da base, e estas duas linhas serão do comprimento que deverá ser a altura edifício. Assim, entre as suas linhas extremas, que fazem a altura, tomam-se as medidas das colunas, das pilastras, das janelas e dos outros ornamentos desenhados na todo sempre projetando, de quaisquer pontos das extremidades das colunas, pilastras, vãos, ou o que se queira, linhas paralelas àquelas duas extremas. E depois com uma linha transversal se coloca a altura da base das colunas, dos capitéis, das arquitraves das janelas, frisos, cornijas, e outras coisas. E isso tudo se faz com linhas paralelas à linha do plano do edifício. [aqui Rafael descreveu a construção da elevação]. E em tais desenhos não se diminui nas extremidades, mesmo que o edifício seja circular, ou mesmo de planta quadrada, para mostrar, ou mes duas faces. [ou seja, esses des ão poderiam ter ponto de fuga, isto é, não seriam perspectivas]. Porque o arquiteto, da linha diminuída [característica da perspectiva] não pode pegar medidas justas, tornando necessário para isso, que investigue todas a proporções perfeitas de fato, e tire-as a partir das linhas paralelas, e não com aquelas que parecem, mas não são; e se, as proporções feitas sobre a planta de forma redonda aparecem cortadas em elevação, ou diminuídas, no mesmo instante podem ser lidas no desenho da planta, e aquelas que aparecem cortadas [distorcidas em relação à sua 
verdadeira forma] na planta, como abóbadas, arcos, frontões, são então perfeitas em suas elevações. E, por isso, é sempre necessário ter prontas e certas as dimensões corretas em palmos, pés, dedos e grãos, até suas partes mínima". (RAFAEL, 1978, p.476).

Até aqui Rafael comentou sobre as propriedades da projeção ortogonal da elevação em comparação com a perspectiva. Nota-se que, como Alberti, Rafael também considera a perspectiva como um artifício que pode transmitir falsas informações ao projeto. E assim segue descrevendo a elevação interna.

\begin{abstract}
A terceira parte deste desenho é aquela que dissemos e chamamos 'parede de dentro', com seus ornamentos. E esta é tão necessária quanto as outras duas, e é feita igualmente a partir da planta com linhas paralelas, como a parede de planta com linhas paralelas, como a parede de
fora; e mostra a metade de dentro do edifício, fora; e mostra a metade de dentro do edifício,
como se esse estivesse dividido ao meio: mostra como se esse estivesse dividido ao meio: mostra
o pátio interno, a correspondência da altura das cornijas de fora com os elementos de dentro, a altura das janelas, das portas, dos arcos e das abóbadas, circulares ou em cruz, ou de qualquer outra forma que apareça. Em suma, com estas três ordens - ou modos - podem ser consideradas todas as partes de cada edifício, dentro e fora. (RAFAEL, 1978, p.477).
\end{abstract}

A partir desse trecho, Rafael descreve a construção da perspectiva segundo a reprodução do cone visual. Conta que, definido o plano da perspectiva, os objetos que aparecessem à frente desse, estariam aumentados e os que estivessem depois pareceriam diminuídos. E segue, afirmando, quanto maior o ângulo do cone visual, maior será a distorção que o objeto sofrerá. Caberá ao arquiteto ou pintor, escolher o que e como representar. Porém, reforça que esse modo de desenho é próprio do pintor, ainda que conveniente ao arquiteto.

Porque, como ao pintor convêm representar a arquitetura para saber fazer seus ornamentos bem dimensionados e com suas devidas proporções, assim ao arquiteto interessa saber a perspectiva para que com esse exercício imagine methor todo o dificio fornecido com seus ornamentos. (RAFAEL, 1978, p.480).

Para Rafael, seguindo e completando o pensamento de Vitruvio e Alberti, o desenho deveria ser elaborado para garantir uma relação real com o edifício, portanto deveriam ser precisos e representar o objeto de todas as maneiras possíveis para garantir seu total entendimento.

O acréscimo da elevação do interior às duas propostas por Alberti (planta e corte "simplificado") não alterava o sistema de representação. Todavia, se Rafael imaginou como parte do terceiro tipo uma seção das paredes que indicasse a espessura ou a relação entre o interior e o exterior, isto representou uma significativa evolução em relação ao seu predecessor, tornando possível "considerar minuciosamente todas as partes de cada edifício" (ACKERMAN, 2003, p.51).

Até Rafael se tornar encarregado das obras da Basílica de São Pedro, na Itália, a planta e o modelo tridimensional eram considerados os únicos documentos necessários e suficientes para poder construir um edifício.

A novidade na carta de Rafael a Leone X, em 1519 , reside em sua separação sistemática de planta, elevação e seção - bem respaldada pela 
teoria - mas também em sua definição da projeção ortogonal. É difícil crer que as idéias que expressava não estivessem sujeitas a discussões e provas práticas no canteiro de São Pedro. (...) Peruzzi e Giuliano da Sangallo [também] se valeram do novo método, ao princípio, com a singular combinação de alguns elementos da perspectiva. (LOTZ, 1985, p.28).

A permanência de Rafael em São Pedro durou seis anos. Não é coincidência o fato de que seus projetos para a basílica, datados precisamente nesses anos, sempre tenham sido considerados obras mestras da arte gráfica. Para Rafael, que era antes de tudo pintor, o desenho sem dúvida era o meio natural tanto para projetar como para executar um projeto. Para conseguir compreender todas as medidas e saber como encontrar todas as partes do edifício sem erros, os métodos antigos, graças aos quais, todavia, tinham sido necessários para representar os edifícios mais simples de Brunelleschi e Bramante, agora pareciam necessariamente insuficientes para Rafael. Somente a projeção ortogonal poderia reproduzir um edifício semelhante ao que era, e em relação ao que se havia projetado. Dessa forma, pode-se perceber que sua explicação sobre a projeção ortogonal a Leon $X$, trazia a síntese de muitos estudos teóricos relativos também à sua atividade em São Pedro.

Atarefado como estava por numerosos encargos, Rafael teve de estabelecer um método que pudesse determinar suas intenções arquitetônicas, e que ainda assegurasse a continuidade do trabalho inclusive durante sua ausência. Para conseguir este objetivo necessitaria de outro arquiteto, ou alguém que pudesse interpretar os planos e supervisar sua execução na obra.
Figura 22 - Antonio d Sangallo, o Jovem. Projeto para São Pedro, Roma. (LOTZ $1985,64)$.

$$
\text { H. }
$$

O primeiro a usar coerentemente a projeção ortogonal descrita por Rafael, para representar um espaço interior por meio de uma seção foi Antonio da Sangallo, o Jovem, em sua condição de colaborador assistente, ou seja, a mão direita de

Figuras 22 e 23 Rafael no canteiro de São Pedro, nos últimos anos de sua vida.

Sangallo foi o único arquiteto importante do Renascimento que veio da linha de artesãos construtores, e trabalhou exclusivamente de arquiteto. Ao contrário de Bramante, Rafael e Peruzzi, que começaram como pintores,

Sangallo não havia aprendido o desenho em perspectiva como parte de sua formação profissional. Por tanto, era mais receptivo às novas idéias de Rafael que Peruzzi, que tinha a mesma idade. Talvez fora esta a razão pela qual Sangallo foi proposto por Rafael para o cargo de Coadjutore. Peruzzi, o pintor, pode ter considerado que a projeção ortogonal oferecia menos possibilidades para a visualização, mas Sangallo, o artesão, deve ter reconhecido suas vantagens de maior clareza e legibilidade. Também deve ter recebido esse método de representação, com satisfação como solução definitiva ao problema de representar um espaço interior por meio de desenho e, por tanto, aderiu-se a ela de modo mais consciente, enquanto que Peruzzi - mais introspectivo "com suas inclinações e seu talento para os 


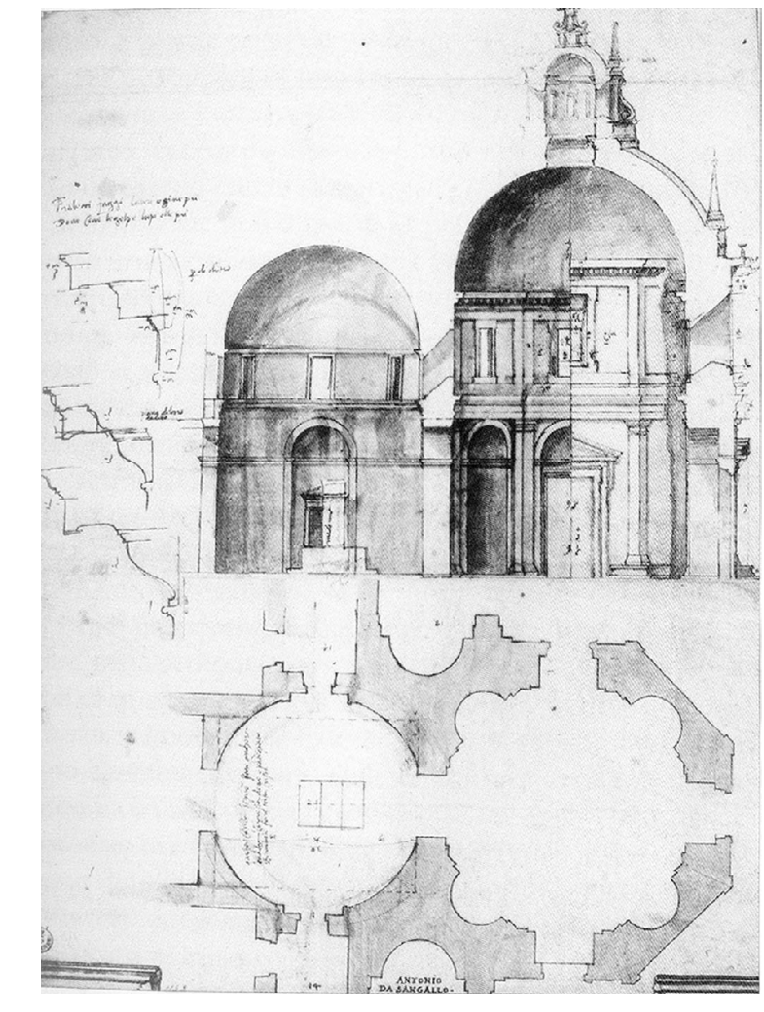

temas teóricos", tentou reconciliar as vantagens de uma representação perspectiva do espaço interior - mais rica, mais visual e de caráter mais pictórico- com as de projeção ortogonal. (LOTZ 1985, p.30).

Ao representar as elevações curvilíneas e poligonais, os desenhos italianos do século $\mathrm{XV}$ mostram um efeito de perspectiva mais sofisticado, ainda que irracional. $\mathrm{O}$ volume em pergaminho de Giuliano da Sangallo, datado dos primeiros Figura 24 anos do século XVI é o equivalente renascentista de uma coletânea de fotografias de arquitetura. Considerado como obra de consulta e lazer perseguia um objetivo diferente dos desenhos indicados por Alberti. Esses documentos apresentam uma visão própria de seu autor e garantem ainda a relação entre seus elementos, mesmo que não fossem utilizados para a construção de uma obra, ou seja, sem a necessidade de um rigor técnico.

Os desenhos relativos a edifícios históricos
Figura 23 - Antonio da Sangallo, o Jovem. Projeto para um edifício centralizado. (LOTZ, 1985, p.64).
Figura 24 - Giuliano da Sangallo. Tumbas romanas, nterior (ACKERMAN, 2003, p.52)

(levantamentos e estudos) constituem um tipo de representação diferente daqueles realizados para um projeto. Enquanto alguns exemplos renascentistas de desenhos para construção eram destinados somente aos desenhistas, a maior parte desses documentos históricos deveriam ser vistos por outros, e, portanto, teriam que satisfazer as expectativas e a capacidade de leitura do observador. Por este motivo são geralmente conservadores e avessos às mudanças significativas, seguindo sempre o uso de perspectivas.

Figura 25

A ilustração de Serlio sobre a cúpula de San Pietro resolve o problema de Giuliano da Sangallo na representação ortogonal em uma única imagem unindo interior e exterior de uma estrutura esférica segundo as indicações de Alberti e Rafael. Essa ilustração, de 1540, aparece quando essa técnica já era mais difundida; portanto Thoenes, em seu estudo Vitruv, Alberti, Sangallo, considera que se trata de uma cópia do 


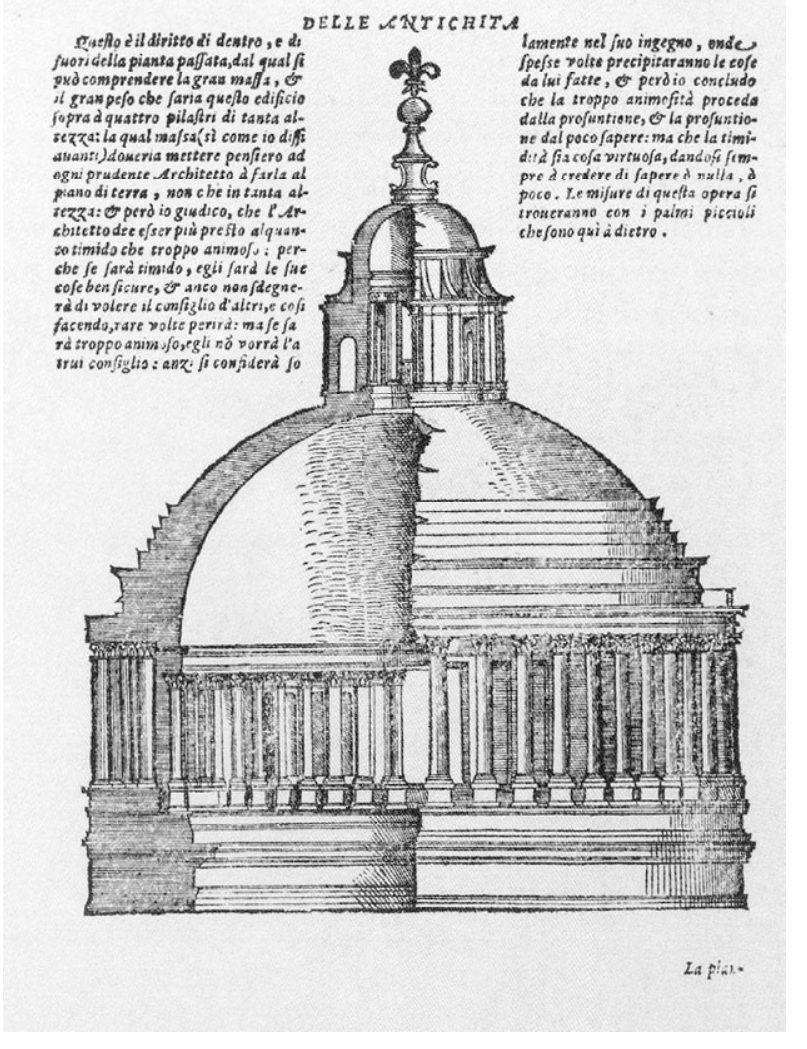

desenho original de Bramante para a cúpula, talvez de 1505-06, quase contemporânea ao desenho de Giuliano da Sangallo. Considerando-se esse fato, este desenho poderia ser indicado como o primeiro desenho verdadeiramente ortogonal italiano de um edifício não retilíneo, traçado a partir de uma planta. Bramante e seus auxiliares na construção de San Pietro (em particular Antonio da Sangallo, o Jovem) inauguraram uma nova era, na qual os arquitetos passariam a requisitar desenhos mais precisos e completos tanto para testemunhar os vestígios clássicos quanto para desenvolver novos projetos.

Porém, entre os observadores leigos e os mecenas, o efeito pictórico continuou a prevalecer sobre a exatidão das medidas, como aparece em uma representação do Pantheon, presente em um volume da década de vinte do século XVI no qual eram representados os principais monumentos de Roma, antigos e modernos. O autor, Bernardo della Volpaia, mostra a metade de um interior e uma seção predominantemente Figura 26
Figura 25 - Sebastiano Serlio. Projeto de Bramante para a cúpula de São Pedro, Roma 1514. (ACKERMAN, 2003, p.53.

Figura 26 - Bernardo della Volpaia. Corte em perspectiva do Pantheon, 1515. (ACKERMAN, 2003, p.54)

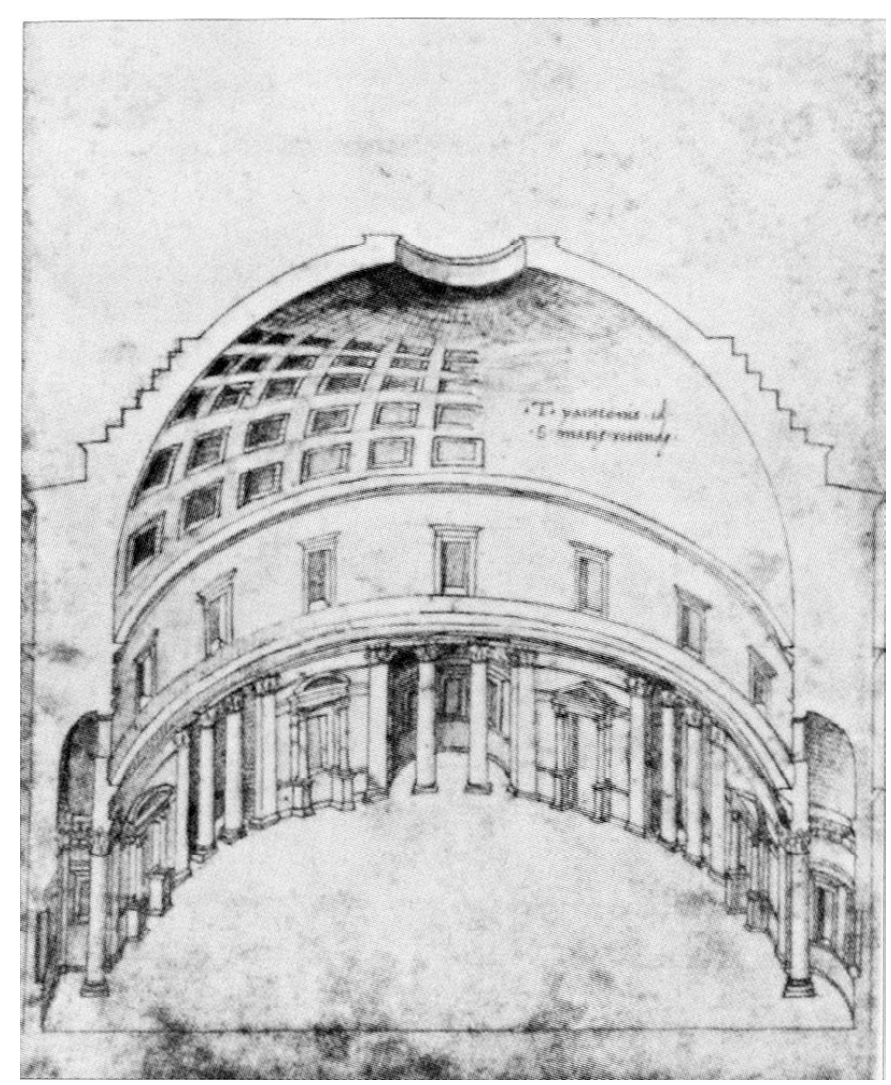

imaginada do Pantheon; a ilustração não é projetada de maneira sistemática e constitui um exemplo de perspectiva subjetiva.

É importante ressaltar que as perspectivas de caráter visual, isto é, as que representam a imagem obtida por um observador, mesmo tendo alcançado um nível autêntico de qualidade gráfica, não eram consideradas documentos de projeto. Nesse momento, eram utilizados também, os cortes perspectivados, que, na verdade, eram mais próximos de uma variação de corte do que uma busca por visualizar o aspecto final da obra. E que visavam representar as formas mais complexas do edifício, como as cúpulas.

A representação não se restringe mais a uma planta e uma maquete, um sistema gráfico começa a se regularizar, embora tenha sido praticado intuitiva e coerentemente antes mesmo do Renascimento. 


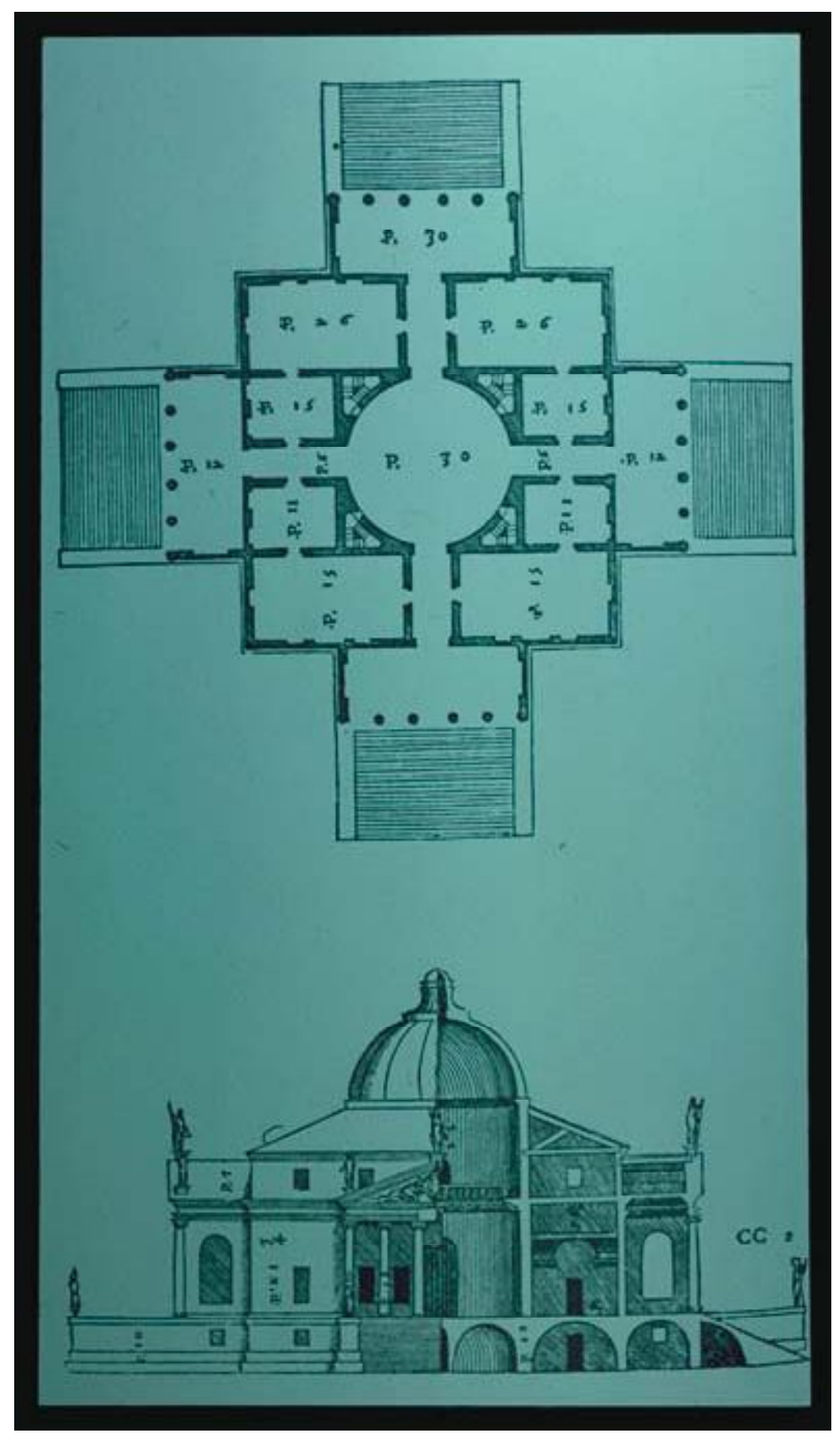

Figura 27 - Andrea Palladio. Planta, corte e elevação. Villa Rotonda, Vicenza, 1567 (HEYDENREICH, 1998 p.156).

Federico Zuccari, presidente da Academia di San Luca, em Roma, no século XVI, desenvolveu em sua obra teórica o conceito de desenho arquitetônico, considerando a dupla significação que Alberti já havia mencionado. Em seu livro L'idea de'scultori, pittori e architetti, Zuccari definiu o disegno em duas componentes: disegno interno, ou seja, a idéia que o artista tem em sua mente e que pretende transmiti-la ao mundo; e o disegno esterno, que significa a representação gráfica propriamente dita, isto é, a forma concreta de materialização das idéias do artista.

Ainda que o sistema de projeções não havia sido desenvolvido cientificamente e nem universalizado no âmbito da arquitetura, podem ser encontrados muitos exemplos de usos dos vários tipos de projeções no século XVI, cada um expressando o que considerava a melhor forma de representação de projeto. Entre eles, Jacques-Androuet du Cerceau, com Les plus excellents bastiments de France, e Andrea Palladio, em I quattro libri. O primeiro apresenta todos os sistemas de projeção geométrica utilizadas em seu tempo, e o segundo aplica a teoria de Rafael e apenas utiliza-se de projeções ortogonais. Em todo o tratado, rico e amplamente ilustrado, somente dois desenhos são perspectivas - quando apresenta uma ponte e faz uma ilustração do muro. Enquanto Cerceau, como desenhista, procurava o melhor sistema para Figura 27 representar o objeto; Palladio, como construtor, procurava o rigor das medidas.

O tratado de Palladio, com grande aposta na imagem, pressupõe que o projeto de arquitetura, enquanto desenho, não deveria fazer referência ao real, mas ao ideal. $O$ projeto deveria se apresentar em uma série de esquemas convencionais, os quais deveriam ser traduzidos e executados por pessoas de igual conhecimento e competência para interpretá-lo. A partir de então, esses ficariam responsáveis por escolher e construir modelos sobre o que fosse necessário ou mais importante para a construção.

Os projetistas que souberam vencer a atração pela perspectiva na representação dos elementos recuados e avançados foram os primeiros a ter uma formação de 


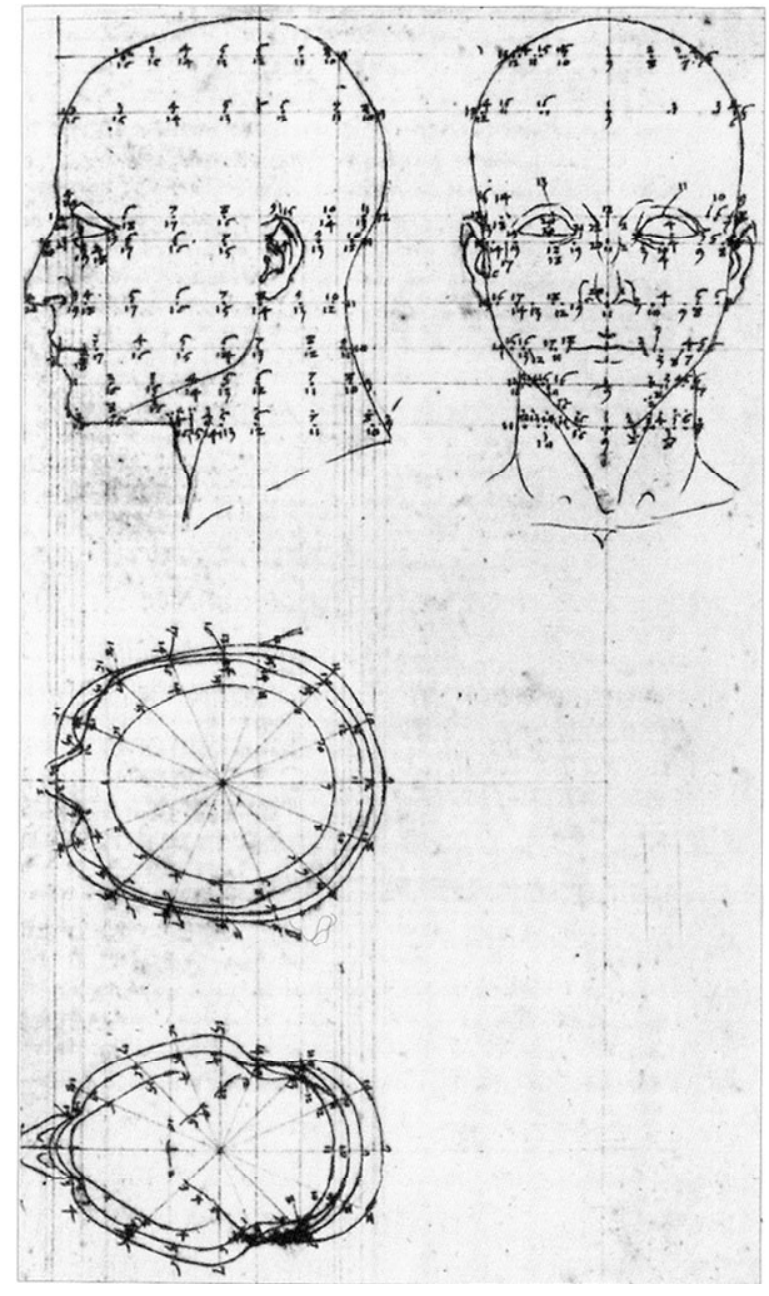

arquitetos e não de artistas figurativos: Antonio da

Sangallo, o Jovem, e Palladio. O desenho do primeiro para uma igreja em Monte Moro coloca em prática o princípio de Alberti (salvo pelo uso de sombra), com a maior clareza ao apresentar a seção à esquerda, e a elevação a direita. Por uma questão didática e de fácil leitura, o desenho foi alinhado verticalmente à planta do edifício dado que a projeção ortogonal deveria ser construída a partir da planta com uma régua T ou um esquadro, e assim poderia, depois, ser lida adequadamente se associada a esta. A técnica de transferência de um plano a outro é fundamentalmente a mesma da construção das figuras na obra De prospettiva pingendi de Piero della Francesca, na qual o resultado se dá a partir das paralelas necessárias às mudanças de planos. Paradoxalmente, foram as avançadas pesquisas de Piero della Francesca sobre perspectiva pictórica que forneceram aos arquitetos a oportunidade de vencer a paixão pela perspectiva subjetiva. Palladio colocava quase sempre os desenhos do interior e do exterior provenientes de volumes curvilíneos ortogonalmente em relação à planta, e assim como Alberti, raramente usava o recurso de sombreamento para representar algum relevo.

Uma outra forma de representação em arquitetura que surgiu nesse mesmo momento foi a axonometria, considerada um sistema intermediário entre a projeção de uma imagem de um objeto arquitetônico sobre uma série de planos ortogonais e sua reprodução, segundo as leis da percepção visual. Esse tipo de representação permite incluir as três dimensões sem perder suas propriedades geométricas.

O caminho desse elemento de representação seguiu paralelo ao da perspectiva com um ponto de fuga. A descrição científica da axonometria é atribuída ao matemático francês Gérard Desargues (1591-1662), que desenvolveu sua geometria projetiva um século e meio antes do seu desenvolvimento em leis de geometria descritiva, por Monge. Essa representação também tem pequena presença na Idade Média, onde era construída de forma intuitiva, enquanto não teorizada, assim como outras formas de representação empregadas.

Porém a axonometria era mais utilizada por profissionais ligados a grandes máquinas e invenções.

No século XVII, engenheiros militares e experientes em mecânica definiram a técnica do desenho axonométrico, o qual permitia a representação tridimensional do edifício e, ao mesmo tempo, garantia a exatidão das medidas projetadas sobre o plano de fuga. (ACKERMAN, 2003, p.254). 


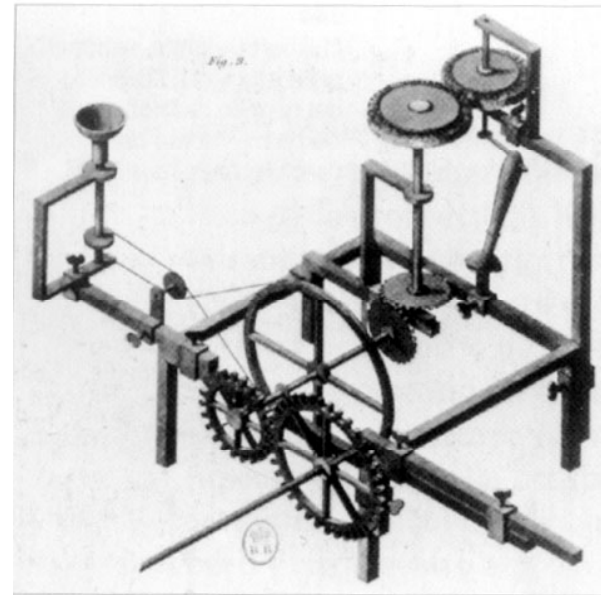

Embora trouxesse uma relação fiel às dimensões do objeto, o desenho axonométrico não foi uma forma de representação muito utilizada na história do desenho arquitetônico, talvez porque a primeira vista causasse estranheza, por não apresentar um caráter visual ou a expressão do arquiteto para o espaço idealizado.

Um exemplo de axonometria empregado no século XVI, é de Baldassare Peruzzi, que o utilizou em alguns de seus Figura 30 desenhos construídos geometricamente. A ele atribui-se o uso de axonometria a seu interesse por projetos de cenografia teatral ilusionista, e não por conhecer uma base cientifica do uso dessa representação.

A axonometria tem caráter intermediário por não se caracterizar como uma vista que permite apreender o edifício assim como será e tampouco serve como um objeto guia para construção, porém revela-se como um instrumento para apresentar a idéia do conjunto, de forma muito técnica, científica e impessoal, onde qualquer pessoa acostumada à técnica consegue compreender o projeto.

No século XVIII, Auguste Choisy apresentou um desenho em axonometria que possibilitava apreender a planta, o interior e o exterior de uma abóboda romana. O método 


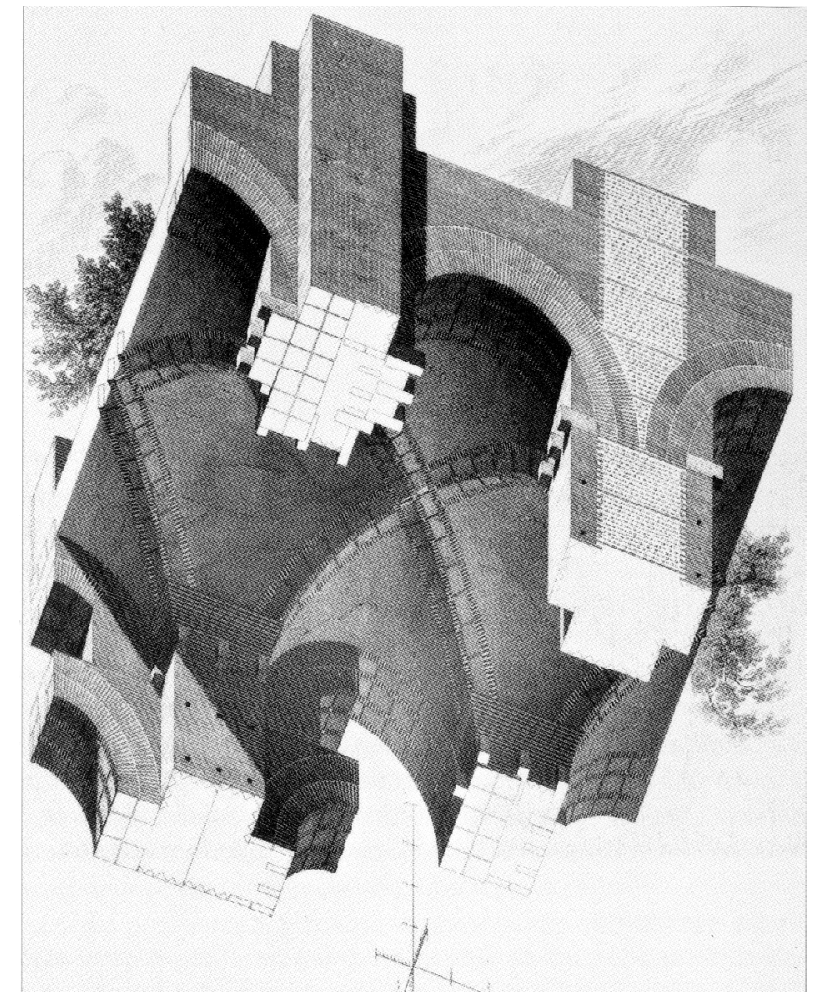

reconhecimento permitiu aos arquitetos e artistas considerarem seus desenhos como produtos individuais e pessoais, o que acarretou uma grande valorização da representação gráfica de arquitetura, agora, tanto por seu valor arquitetônico, quanto por seu valor artístico.

No século XVIII houve novamente uma revisão dos Figura 31 conceitos sobre o desenho de arquitetura. Essas novas definições vieram das mãos dos franceses a partir da segunda metade do século.

Em 1755, Augustin-Charles D'Aviler definiu o desenho como a representação geométrica ou perspectiva daquilo que se tem projetado, em seu Dictionnaire d'architecture civile et hydraulique. Essa definição incluiu o uso da perspectiva como representação de arquitetura. Para D'Aviler, não apenas as projeções ortogonais eram consideradas desenho arquitetônico, contrapondo seu pensamento ao de Rafael, até então considerado a base científica mais atual e desenvolvida.
Figura 32 - Filippo Juvarra. Vista do Castelo de Rivoli, 1721. (SAINZ, 1990, p.26).
Figura 31 - Auguste Chois

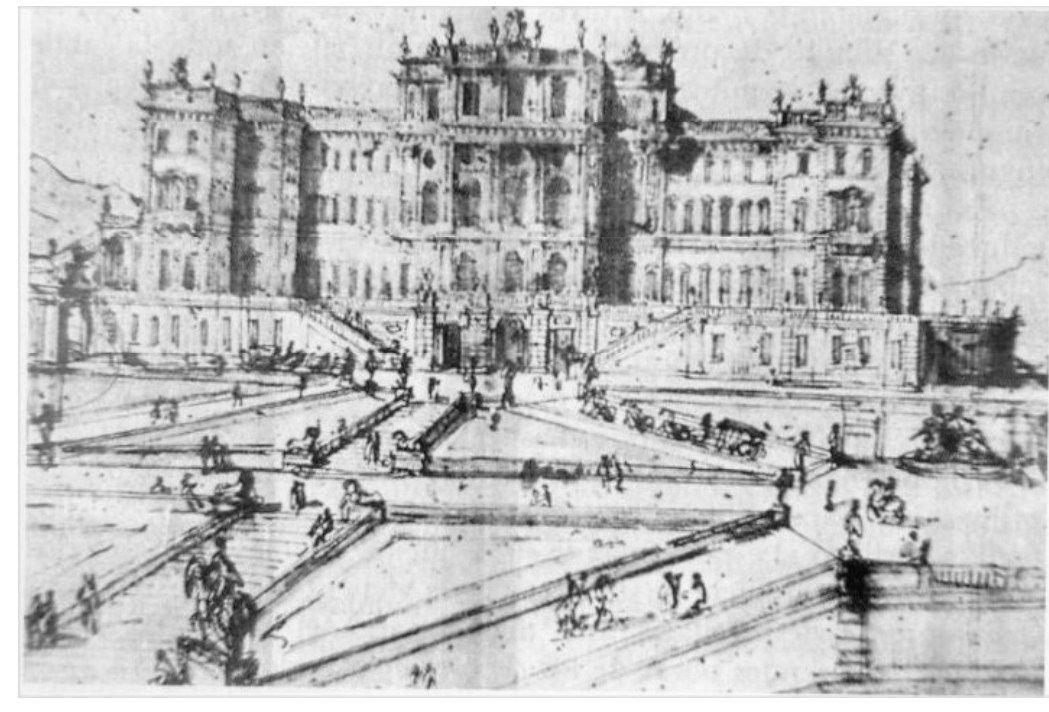

A perspectiva no âmbito de arquitetura só passou a ser documento de projeto no século XVIII, ainda assim, apenas como uma forma de visualizar o objeto construído e não como

Figura 32 garantia de uma relação métrica verdadeira, como nas obras de Filippo Juvarra e Johann Bernhard Fischer Von Erlach. Porém, esse costume só se desenvolverá no século XIX, com os "perspectivistas" ingleses e suas grandes obras.

Em 1770, há uma generalização ainda maior sobre o termo desenho, por parte de Roland Le Virloys, em Dictionnaire d'architecture civile, militare et navale, que define desenhar como expressar, ou representar alguma coisa, com lápis ou de outro modo qualquer. Essa definição torna-se importante por ser a primeira vez que o desenho é considerado mais do que representar algo, incluindo a partir de então, o conceito de forma de expressão de idéias, como uma atividade criativa do arquiteto.

A teoria sobre o desenho arquitetônico, conforme se apresenta hoje, é fruto do estudo do matemático Gaspard Monge, em 1798, presente em sua obra Géométrie descriptive. Monge estabeleceu as bases da geometria descritiva e codificou cientificamente todos os sistemas de representação utilizados 
em arquitetura até o período: projeções ortogonais, perspectivas e axonometria. E ainda acrescentou o estudo de projeções obliquas, necessárias para o cálculo de sombras. Assim, Monge estava gerando e comprovando uma base científica para um sistema de representação que há tempos vinha sendo utilizado de forma intuitiva.

O estudo de Monge tornou possível a criação de um Figura 33 sistema de comunicação no meio arquitetônico. A partir de então, a produção arquitetônica em geral passaria a ter uma base cientifica de apoio, onde os desenhos deveriam ser plenamente descritivos e de significado unívoco. Assim sendo, o mesmo objeto deveria ser representado igualmente por todos que estivessem usando o mesmo sistema de projeções, o que tornaria os desenhos impessoais e de linguagem universal.

Sob o ponto de vista de Ackerman, em seu estudo sobre instrumentos e a representação arquitetônica, o papel transparente, ou vegetal, introduzido no século XVIII, trouxe novo desenvolvimento das idéias de projeto. A partir de então, não era mais necessário despender tempo para transferir de uma superfície opaca para outra. E isso permitiu uma maior interação entre planta, corte e elevação.

Seguindo esse raciocínio proposto por Ackerman, pode-se supor que o desenvolvimento de novos instrumentos para o desenho também acompanhou novas características na arquitetura representada em cada período. De pergaminhos para papel, de pontas de aço para penas, aquarelas, e outros materiais que enriqueceram a representação gráfica ao longo dos tempos.

Durante todo o século XIX, o conceito de desenho

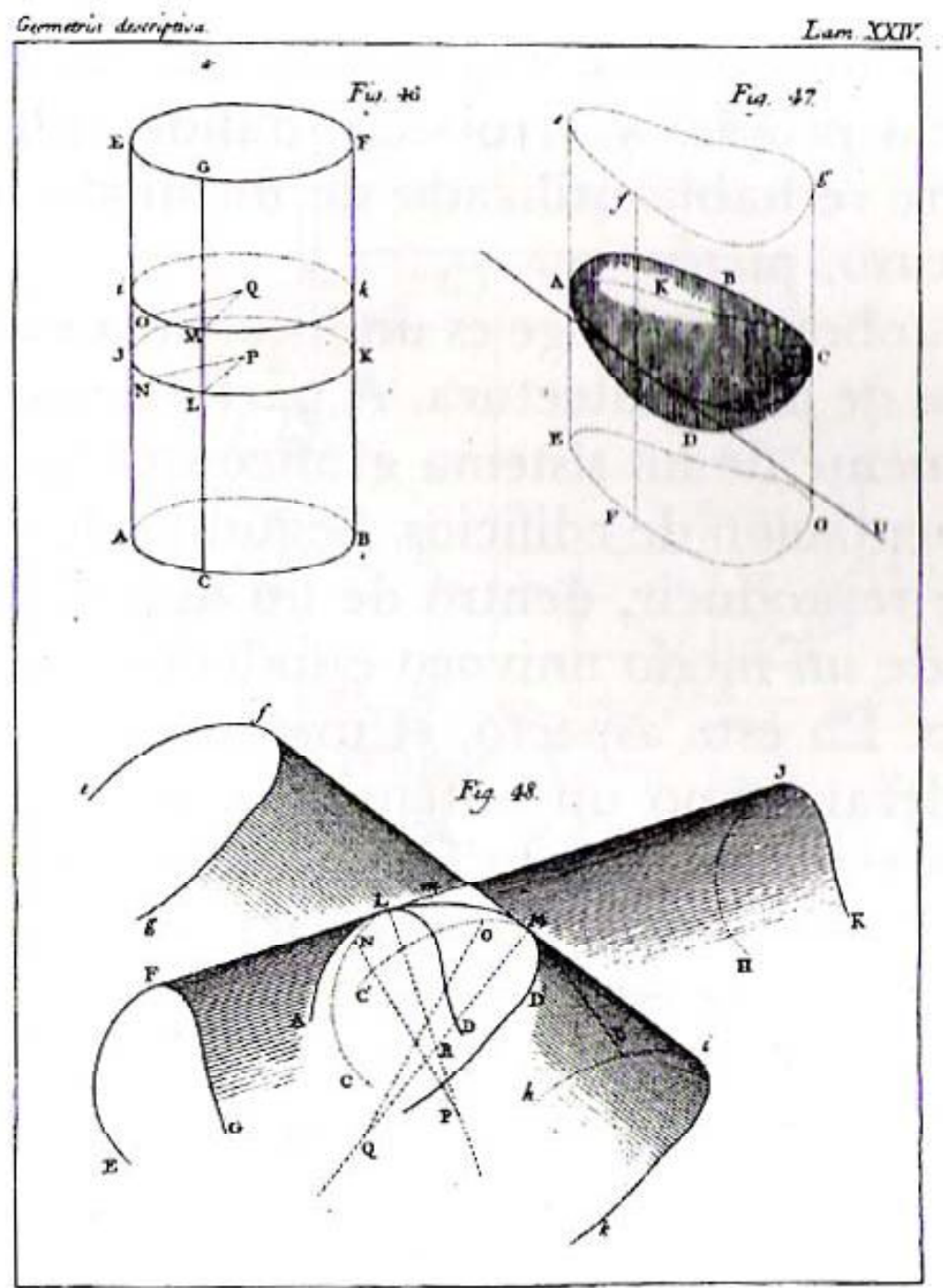

arquitetônico começou a buscar sua autêntica essência e encontrou um lugar próprio dentro do esquema estrutural da arquitetura. A partir de então, haveria diferenças entre desenhos sobre arquitetura e desenhos para arquitetura.

O conceito de desenho arquitetônico deixou de estar vinculado unicamente aos conceitos de representação ou de expressão para abarcar o campo mais extenso de comunicação das idéias arquitetônicas. Pela primeira vez, o desenho tornouse importante na transmissão do raciocínio dos arquitetos, entre eles ou com pessoas ligadas ao processo de edificação.

Em 1902, século XX, Guédy, em Dictionnaire 
d'architecture, elaborou uma definição para desenho de arquitetura que resume todas as definições anteriores sobre representação de arquitetura.

Em arquitetura o desenho é o pensamento mesmo do arquiteto; éa imagem de um edifício futuro. Antes de elevar-se sobre o terreno, o monumento se desenha e se forma na mente do arquiteto; este o copia desse modelo premeditado, ideal, e sua cópia se converte, por sua vez, em um modelo que deverá ser repetido em pedra, mármore ou granito. O desenho é, portanto, o princípio gerador da arquitetura; é sua própria essência. (SAINZ, 1990, p.56).

Sainz deixa claro que a representação de um projeto depende muito do próprio arquiteto, assim como a época em que está inserido e o que pretende ressaltar em sua arquitetura.

Desde uma elevação em linha pura até uma perspectiva de caráter quase fotográfico, as variações são quase infinitas. Nenhuma destas variáveis gráficas faz um desenho melhor ou pior. Cada procedimento tem suas vantagens e seus inconvenientes. As vezes, a escolha corresponde a uma determinada opção pessoal de quem desenha, mas em outras ocasiões, as qualidades da própria arquitetura a ser representada, favorecem certos métodos gráficos. O mesmo edifício pode ser representado de muitos modos diferentes, e por sua vez, distintos edifícios podem ser desenhados com o mesmo procedimento gráfico. (SAINZ, 1990, p.169).

A arquitetura, enquanto objeto construído, apresentase em três dimensões, e o seu plano de atuação é o espaço. O desenho arquitetônico, como representação e comunicação de uma arquitetura, apresenta-se em duas dimensões, e se constrói sobre o plano do papel, portanto bidimensional. Inicialmente, o que se pode questionar é como fazer uma representação bidimensional de algo que possui três dimensões. Para tentar resolver essa dificuldade de representar a terceira dimensão da arquitetura foi desenvolvida a representação através de maquetes, ou seja, a partir da construção de um objeto reduzido, de igual proporção, composição e estruturação ao edifício que se pretende realizar.

Nem todos os autores e historiadores de arquitetura reconhecem a importância do uso de modelos tridimensionais para representar a arquitetura. Para Sainz, esses modelos significam um meio de representação insuficiente. Segundo o autor da obra El Dibujo de Arquitectura, apesar do modelo permitir observar a composição global do edifício e de seus elementos arquitetônicos, ele não consegue trazer a visualização do projeto para o olhar do observador, ou seja, a visão do edifício em maquete nunca se equivale a do observador dentro da obra, tornando o modelo um meio de representação falso, irreal. Para esse historiador, o uso da maquete física só se torna mais próximo de uma visualização real do edifício nos dias de hoje, onde a macrofotografia permite gerar a sensação de se estar dentro da obra em estudo.

Não se pode negar a estreita relação entre desenhos de representação e modelos tridimensionais. Ambos podem representar um mesmo objeto, cada qual respeitando sua peculiar técnica de execução. O desenvolvimento das técnicas de desenho, tanto em instrumentos, quanto em estudos sobre a geometria, trouxe uma diminuição no uso de modelos para representar a arquitetura. $\mathrm{O}$ desenho começou a se tornar $\mathrm{o}$ 
meio mais rápido e pessoal no processo de projeto. Pode-se arriscar dizendo que a perspectiva foi o instrumento de desenho que passou a substituir a execução de modelos, não por alguma falha, mas pela rapidez e expressão pessoal que o desenho assume sobre o modelo. Alguns historiadores da arquitetura, como Sainz, consideram a perspectiva mais importante que o próprio modelo, porque sua representação é capaz de fornecer uma maior apreensão do espaço tridimensional do ponto de vista do observador.

Vale ressaltar que a perspectiva desempenha uma função importante de caráter figurativo, e além de garantir a aparência que a obra terá depois de construída, também serve como um instrumento de trabalho, que, continuamente, controla o processo de projeto nos aspectos visuais e compositivos, assim como o modelo era usado no Renascimento, porém com muito mais velocidade e sem custos maiores.

Com a convencionalização de um sistema de representação em arquitetura, iniciada no Renascimento e construída ao longo dos tempos, pode-se dizer que, o sistema gráfico de planta, elevação e corte garante uma maior possibilidade de compreensão construtiva do que quando se faz apenas o uso de modelos tridimensionais. Porém, o caminho percorrido entre o entendimento da planta, elevação e corte para se conceber novamente o edifício em forma tridimensional na mente do observador, é muito mais longo e passível de erros que a simples observação de uma maquete. Vale lembrar que realmente, a visão de uma maquete física é completamente diferente da visão de uma perspectiva sobre o projeto. Na perspectiva há a inclusão no espaço representado e na maquete física, a observação traduz-se como um sobrevôo ao edifício idealizado. Com o advento da informática na produção de arquitetura essa afirmação torna-se inválida. $\mathrm{O}$ modelo, não mais físico, mas virtual, confunde-se com a geração de perspectivas. O observador passa a ser sempre incluído no espaço que está sendo projetado. Porém, esse será um assunto discutido no segundo capítulo dessa dissertação. 
Capítulo 02. O modelo tridimensional em arquitetura: noções gerais Por isso sempre me convencerá o velho hábito que tem os melhore construtores, que consiste em meditarmos e considerarmos uma e outra vez a obra em sua totalidade, e cada uma das medidas de todas as partes do edifício, tendo em conta o conselho das pessoas mais experientes, por meio não só do projeto e do desenho, mas também com a ajuda de modelos e reproduções de madeira ou de qualquer outro material, antes de iniciarmos uma empresa que requer gasto e esforço.

(ALBERTI, Livro II, Cap. 1). 
Enquanto mediador entre uma idéia arquitetônica e a obra realizada, o desenho de arquitetura traduz-se em símbolos próprios, definidos por uma convenção universal, teorizada no Renascimento, e consolidada ao longo dos anos, com adaptações e aprimoramento através das novas técnicas e ferramentas desenvolvidas, sem, contudo, perder a essência de seu sistema de representação.

Embora o desenho seja o meio de expressão e comunicação mais utilizado pelos arquitetos, não se pode ignorar a presença do modelo tridimensional, como uma outra ferramenta também importante para a representação em arquitetura.

O uso da maquete significa parte determinante no nascimento e consolidação do arquiteto como figura diferente e contrária àquela do mestre de obras medieval, principalmente na arquitetura italiana. Para Maldonado (1987), a exigência de comunicar o projeto e de satisfazer a necessidade de ver o projeto antes da construção, originou a profissão de arquiteto.

Goldthwaite, grande historiador sobre o Renascimento Italiano, afirma que essa origem da profissão de arquiteto, como alguém capaz de visualizar e interpretar o projeto, com o auxílio de um objeto, desenvolveu-se segundo o interesse de quem os encomendava.

Na ânsia de ver a obra encomendada, antes mesmo do início de sua construção, a fim de garantir que fosse feita a seu gosto, muitos mecenas e figuras nobres do Renascimento, passaram a exigir um modelo tridimensional como forma de apresentação de um projeto. Essa exigência contribuiu para a 
contratação de artesãos (ligados a atividades artísticas), com maior habilidade técnica, na produção de modelos em escalas reduzidas.

A partir de então, esses artesãos assumiram grande importância no âmbito da construção. Não é por acaso, que os grandes arquitetos da época eram de origem artesã, como ourives, carpinteiros, entalhadores, e outros que tivessem habilidade específica para o trabalho preciso em maquetes. “(...) em Florença, Brunelleschi, Ghiberti e Michelozzo provinham originalmente de ourivesarias." (MALDONADO, 1987, p.58).

É interessante perceber também uma relação entre os escultores e os arquitetos na busca pela antecipação da obra, mediante o uso de modelos tridimensionais. Aliás, muitos arquitetos renascentistas também tinham formação em escultura. Dessa forma, pode-se questionar se a origem do modelo em arquitetura não tenha advindo dessa prática em escultura, ou ainda, tenha, no mínimo, andado paralelamente a esta.

O uso de modelo e desenho em escultura advém dos gregos em fase bastante primitiva de sua arte (por volta do século V a.C. - período clássico). Anterior a eles, a escultura era feita direto na pedra, sem um estudo preparatório preciso.

Além da existência de modelos e desenhos preparatórios, segundo Wittkower (1989), acredita-se na presença de "uma inteligência dominante, cuja função seria dirigir a execução coordenada, da qual se encarregava um grande número de trabalhadores" (WITTKOWER, 1989, p.24). Para o autor essa atividade de supervisão e planejamento já
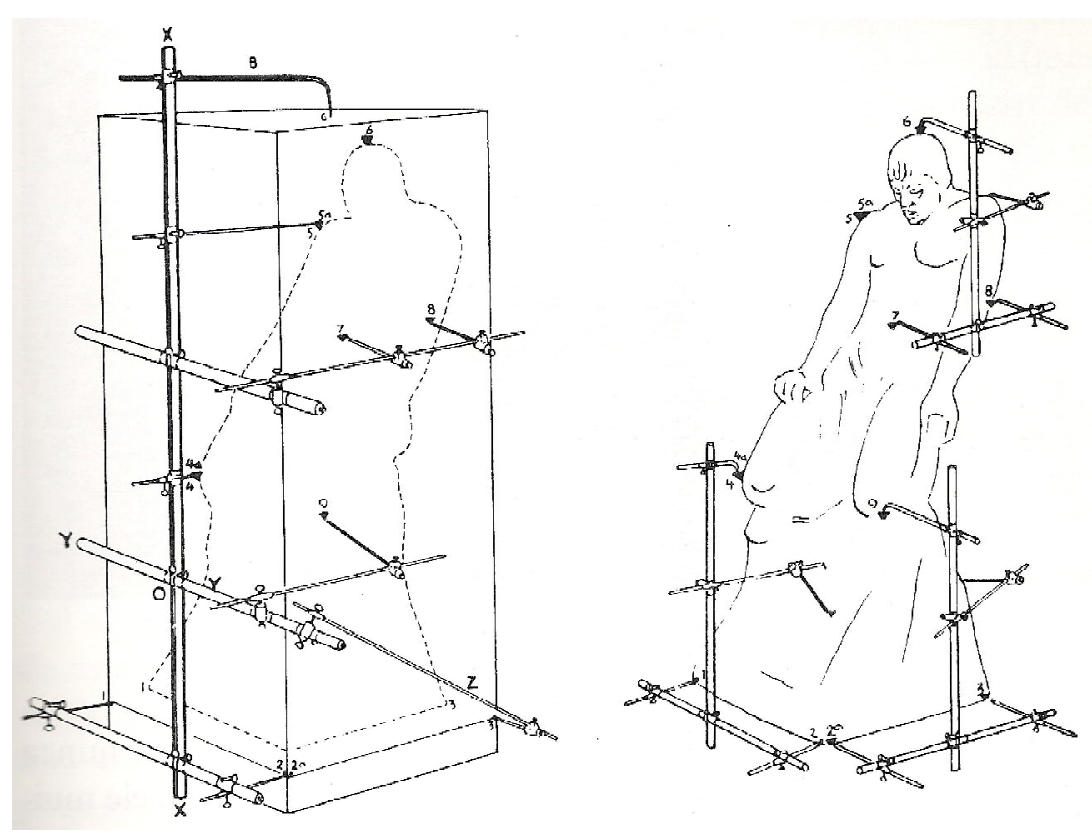
tear (WITTKOWER, 1989, p.25)

acontecia no período clássico grego, na construção de templos gregos, como o Templo de Olímpia e o Partenon.

O método de usar modelos tanto para o planejamento geral das esculturas, quanto para servir de guia em sua execução, são mais antigas do que "as primeiras tentativas de se obter um traslado fiel do modelo para o mármore" (WITTKOWER, 1989, p.24). Anteriormente, os modelos eram apenas usados como forma de averiguação e aperfeiçoamento da idéia do artista.

Para essa transferência do modelo ao bloco de pedra,

Figura 34 os gregos desenvolveram uma máquina de pontear que "consistia em estabelecer, com a maior precisão possível, uma série de pontos paralelos no modelo e no bloco de mármore" (WITTKOWER, 1989, p.25)

Em seu livro Escultura, Wittkower descreve a atividade de escultura a partir das ferramentas presentes em cada período analisado. A ferramenta e o método utilizado em cada momento histórico e cada local sinaliza as características de uma escultura, ou seja, a própria escultura reflete seu método 
de execução, a ferramenta utilizada e até um certo estilo vigente na época de sua criação.

Pode-se dizer que assim como os estilos de escultura e arquitetura caminham paralelos, a presença e forma de criação de seus modelos e desenhos preparatórios também o fazem.

O modelo tridimensional (ou maquete), assim como o desenho, assume um valor de meio de comunicação da idéia arquitetônica, e pode ser definido em três características principais: como um objeto de riqueza própria, quando separado da sua função de representação; como um objeto de registro histórico, que revela hoje a forma de criação e a concepção de alguma arquitetura do passado, não construída ou que não tenha sobrevivido ao tempo; e ainda, como uma ferramenta de estudo, para conceber, representar (e apresentar) um projeto.

As maquetes interessam, principalmente, por sua função de concepção e representação de uma obra, servindo ao mesmo tempo como cristalização de um pensamento e antecipação de uma realidade construtiva. Construído em escala reduzida, o edifício se expõe pela primeira vez ao juízo público.

Para definir este objeto, a palavra maquete tem uso recente. Segundo Pierre-Alain Croset (1987), esse vocábulo deriva da palavra "macchieta", de pequena "macchia", do latim, e designa esboço, rascunho, revelando sua dimensão técnica de processo ideativo, pronto para verificações e correções. A palavra maquete aparece no século XVIII, no vocabulário de belas artes para definir a primeira materialização de uma idéia, da intenção formal do artista.
Em italiano há uma outra palavra que serve para designar maquete: plastico. E para esse termo, Maldonado (1987) revela uma etimologia bastante interessante:

O termo plastico pressupõe a idéia de uma construção física maleável, assim como quando um escultor trabalha com um material como argila. O que traz o termo plastico como sinônimo de maquete, não é um objeto pronto, feito de uma só vez, mas como um processo feito de uma só vez, mas como um processo
aberto e contínuo, que espera intervenções sucessivas do artista, através da modelagem e de novos pensamentos. (MALDONADO, 1987, p.61)

Principalmente por esse termo não ter nascido no âmbito da arquitetura, os arquitetos preferem o uso da palavra 1 Mímesis - igual à imitação,porén diferente de cópia fiel. A mimesis simplifica e extrai a essência da natureza.

modelo. Sob a base da teoria da imitação, literalmente objeto de mimesis ${ }^{1}$, o modelo se coloca para a arquitetura segundo uma função ideal. Derivada do latim modulus e modus, a palavra modelo evoca uma noção de dimensão, de norma, de ritmo, de forma, de limites, até assumir o senso platônico de forma ideal, de paradigma sobre qual se regularizam as existências materiais (CROSET, 1987).

É inútil considerar a maquete como uma reprodução fiel, literal e absoluta da realidade, e crer que o controle de projeto possa reduzir-se à análise crítica da qualidade e dos defeitos de uma maquete. No entanto, o uso simultâneo e complementar dos dois principais tipos de representação desenho e modelo, permite ao arquiteto controlar efetivamente o seu projeto.

A relação entre representação e arquitetura fica clara na interpretação que Perrault faz sobre o tratado de Vitrúvio: “Representar quer dizer concretizar, materializar o pensamento do arquiteto: prever, imaginar, projetar um 


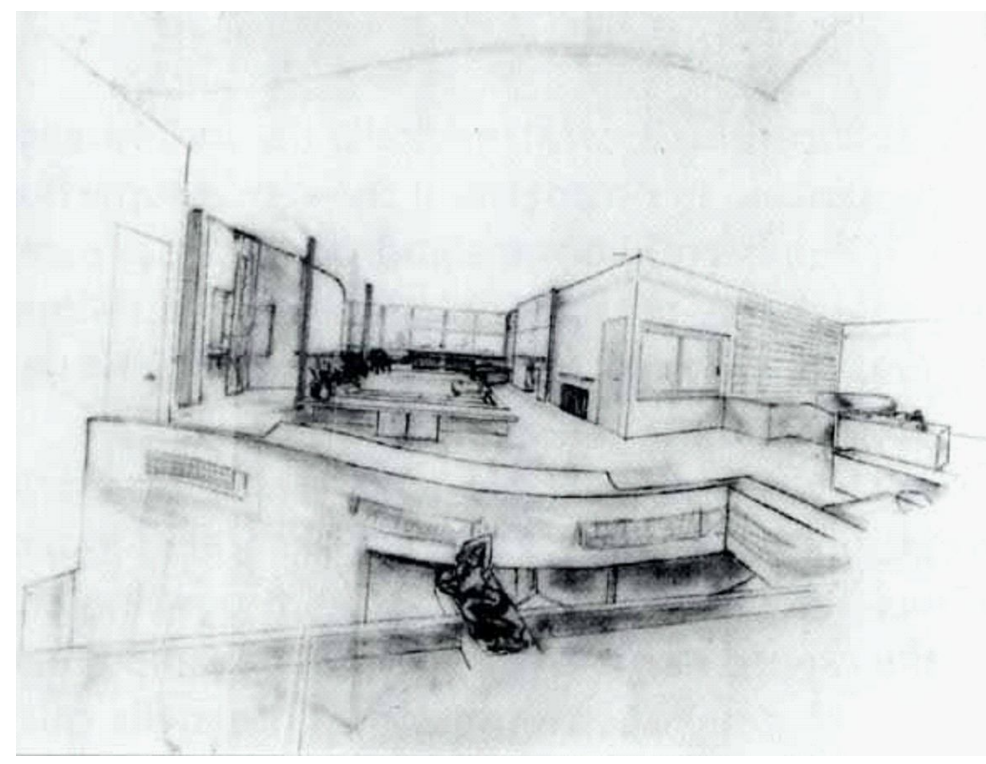

\section{projeto para o interior da casa "Les Terrasses", em Garches (ACKERMAN, 2003, p.253).}

Figura 35 - Le Corbusier,

edifício" (CROSET, 1987, p.48), ou seja, sem o sistema de representação arquitetônica, seja desenho ou modelo, não há arquitetura.

Apesar da rica e variada gama de métodos bidimensionais para representar a arquitetura, nem sempre o sistema gráfico, cuja principal componente é a linha, torna-se o mais adequado. Conforme a arquitetura proposta, principalmente as de elaboradas composições volumétricas, o modelo tridimensional aparece como a melhor forma de representação do todo, transparecendo suas características de cheio/vazio e a relação entre seus componentes.

Ali onde a 'caixa mural' não se divide em planos, em paredes simples e autônomas entre si, mas é projeção do espaço interior, quer dizer cada vez que esta caixa sugere temas predominantemente volumétricos, a técnica representativa deve ser substancialmente diferente. Encontramo-nos perante um fato meramente volumétrico-plástico que apenas pode ser representado com a técnica de maquetes. (ZEVI, 1978, p.40)

Le Corbusier, em seu projeto para a casa em Garches, Figura 35 mostra ser necessária apenas a representação bidimensional.
$\mathrm{O}$ arquiteto usa a perspectiva como instrumento de uma interpretação retórica do espaço que pretende concretizar, insinuando sua visão, frente ao que estava buscando na época. "A perspectiva interna de Le Corbusier, para o projeto de uma residência, tende a exagerar a profundidade do espaço e o jogo de planos abstratos, enfatizando o revolucionário contraste com as salas de estar da classe média do final do século XIX". (ACKERMAN, 2003, p.253).

Segundo Migliari, em Geometria dei modelli (2003), podese dizer que as perspectivas, presentes principalmente na produção da arquitetura moderna, são os mais simples modelos de arquitetura. A elas, o autor atribui o nome de modello grafico. Para Migliari, "Se este suporte é o papel, o modelo, desenhado com o lápis ou com a caneta, é um modelo gráfico" (MIGLIARI, 2003, p.16). O autor ainda acrescenta que a perspectiva de arquitetura difere muito de qualquer outra, porque sua representação se ocupa em apresentar a obra e seu entorno, de forma que a mente do observador consiga reconstruí-la no espaço, e assim entender a presente proposta de arquitetura, ou seja, o conceito arquitetônico.

No decorrer da história sobre o desenho como representação de arquitetura, pode-se perceber que a representação gráfica foi sendo pautada sobre bases científicas muito bem desenvolvidas e justificadas. Acredita-se que a partir do momento em que o desenho de representação se estabilizou e adquiriu um completo conjunto de informações necessárias e suficientemente claras e objetivas para representar um edifício, o modelo tridimensional passou a se apresentar como um objeto de estudo (e não mais necessariamente de apresentação), colocado a serviço de uma representação mais específica e universalizada, isto é, o 


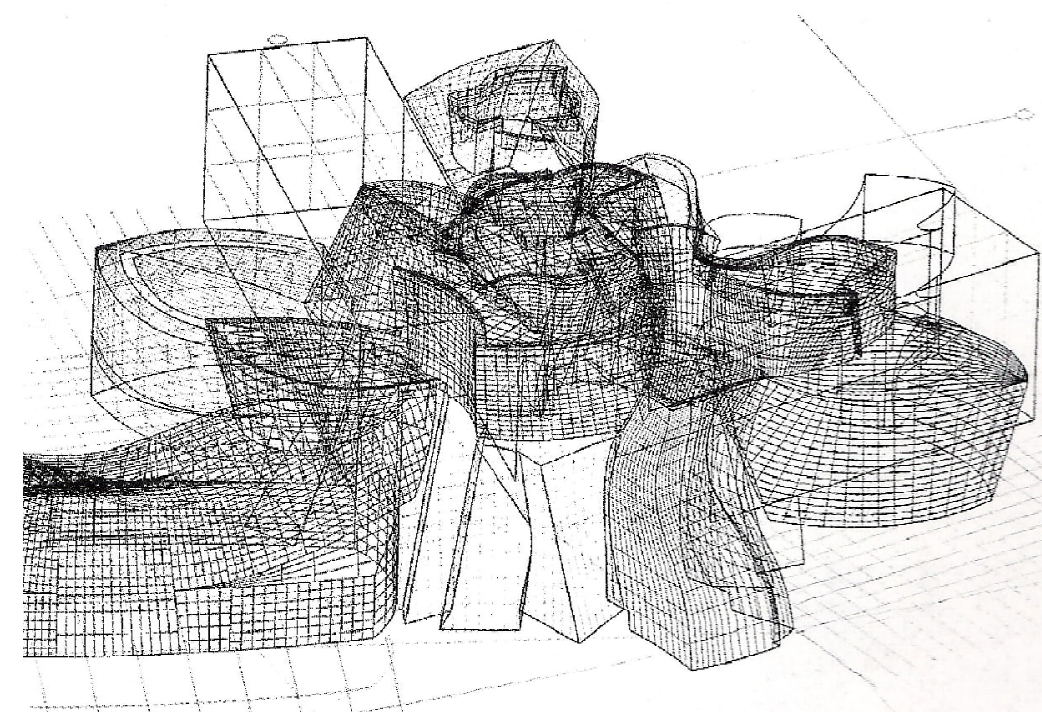

desenho arquitetônico

A partir do momento em que o desenho arquitetônico encontra-se completamente desenvolvido, conforme seu sistema atual de representação, arrisca-se dizer que a arquitetura moderna utilizou-se mais desse sistema gráfico para representar sua arquitetura, talvez até abandonando um pouco o uso de maquetes. A presença da perspectiva de um ponto de fuga e da axonométrica, pode ter sugerido aos arquitetos modernos a representação gráfica da leitura e do estudo que o modelo tridimensional proporcionava ao arquiteto renascentista.

Nesse momento, com base em algumas informaç̃es sobre a existência de maquetes nas décadas em que se projeta a arquitetura moderna, pode-se apontar uma ligação entre o uso do modelo e a indústria, que se apropria desse como protótipo ou como um objeto utilizado no processo de verificação de alguma ação que se pretende analisar, como iluminação, ventilação, ações da natureza, entre outros. É uma representação do construído e não uma forma de estudo do que se pretende construir, ou seja, parece ser retirado do modelo uma importância maior de estar ligada à essência
Figura 36 - Frank Gehry estudo para o muse Guggenheim de Bilbao, Espanha. (ACKERMAN, 2003, p.263).

Figura 37 - Frank Gehry, museu Guggenheim de Bilbao, (www.artlex.com)

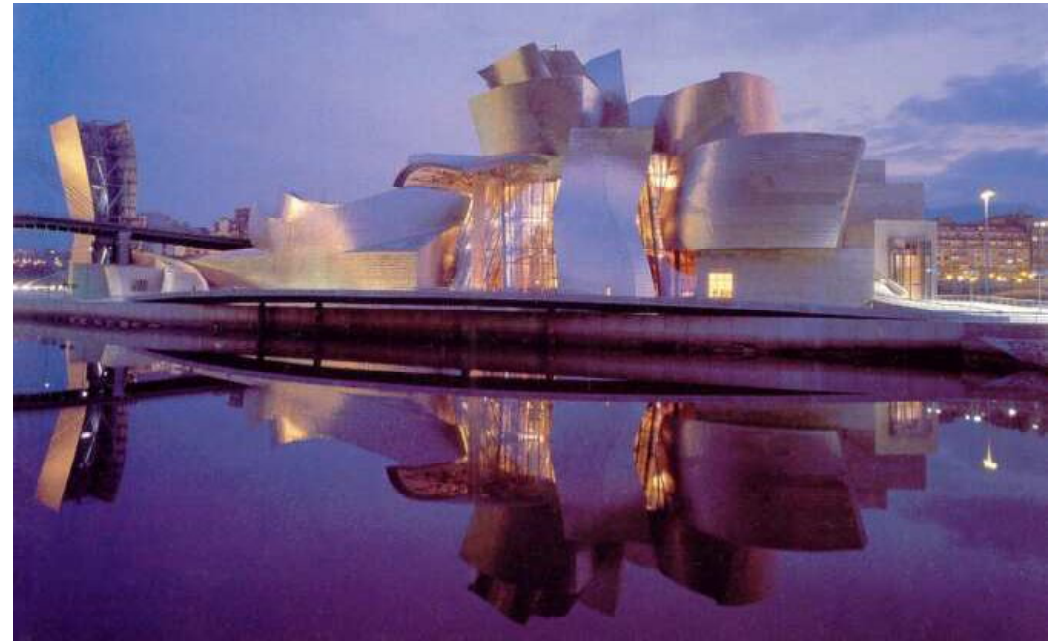

própria da criação da arquitetura. Segundo Marco Gaiani, no texto Del disegno e del modello: rappresentazioni per il Disegno Industriale, a partir desse momento, raros são os arquitetos que necessitam do modelo para projetar sua arquitetura. Apenas se utilizam dele quando o desenho não é o meio mais apto para representar claramente o que estão projetando, como fo o caso de Le Corbusier na Capela Nôtre Dame de Ronchamp, e como se apresenta atualmente, com muitos arquitetos que se lançam em uma arquitetura de complexas composições

Figuras 36 e 37 volumétricas, como Frank O. Gehry. Atualmente, pode-se falar da presença de modelos virtuais para a arquitetura. Embora se apresente com uma nova forma, digitalizada, informatizada, o modelo aos poucos vem retomando a importância e a prática comum que lhe era atribuída no Renascimento, ou seja, conforme suas origens. 
Nesse estudo há a busca por um panorama sobre o Renascimento, evidenciando os enfoques que perpassaram o campo da arquitetura, como por exemplo, o estudo da natureza, as relações de proporção entre os corpos, a noção de beleza e o resgate da arquitetura grega e romana da Antiguidade, além da grande oposição à Idade Média, período cronologicamente precedente.

O Renascimento, período que abrange os séculos XIV ao XVI, nasce com esse termo por ser considerado um retorno às tradições clássicas - as bases da civilização Greco-romana. Os artistas do Renascimento se consideravam pares daqueles que viveram na Antiguidade, e por isso, a partir de suas disciplinas e conhecimentos, poderiam fazer obras como aqueles.

Considerando a Idade Média como um período de trevas (ainda que equivocado), os renascentistas se enalteciam pela possibilidade de retomar a glória das artes e arquitetura no Renascimento. Retornaram, portanto, à "fonte do saber" a antiguidade Greco-romana, e adaptaram seus ensinamentos a essa nova época que estava se iniciando. As ordens arquitetônicas presentes na arquitetura da Antiguidade foram muito estudadas e revisadas no Renascimento. Muitos tratados desse período, como De Re Aedificatoria, de Leon Battista Alberti; Trattato di architettura, de Filarete; Tutte l'opere d'architettura et prospetiva, de Serlio; Regola delli cinque Ordini d'archittetura, de Vignola, entre outros, traziam a interpretação dessas ordens, de acordo com a visão e o estudo do próprio autor. Cada um procurava afirmar ser a sua, a versão mais próxima da "verdadeira" (a Antiga).

O tratado de Vitruvio Pollione, De Arquitectura, escrito 
no século I a.C., norteou a visão que os renascentistas adquiriram sobre a Antiguidade. Esse documento reúne as áreas de atuação do arquiteto, definindo e fundamentando sobre uma base sólida e racional essa profissão no mundo antigo, através de duas atividades: fabrica e ratiotinatio, ou seja,

(...) a prática ou construção, a intelectual ou exposição teórica. A construção consiste no prático exercício contínuo ou consumado, através do qual, com as mãos, a matéria assume a forma desta ou daquela obra que se deseja, segundo o projeto. A exposição explica e dá razão às coisas construídas a partir da preparação teórica com o cálculo das proporções. (FERRI, 2002, p.89).

Esse tratado apresentava edifícios da arquitetura grega e romana, sem uma cronologia, apenas escolhidos por sua essência ou solução ótima aos olhos de Vitruvio. Na arquitetura grega havia uma grande preocupação com as ordens e proporções. Essa arquitetura nasceu da observação da natureza, através da retirada e aplicação da symmetria (harmonia, proporção entre as partes) na edificação. A harmonia, para os gregos, gerava a beleza dos seres, e estava presente na natureza e na música, através de sua proporcionalidade. A proporção da natureza estava presente nos seres e era algo natural, sem convenções; a da música, a escala harmônica de Pitágoras, pautava-se em uma relação fixa retirada dessa mesma natureza, segundo uma ordem matemática, que deveria ser sempre respeitada. Em suma, a beleza e essa ordem matemática inscrita na natureza era uma só. Essa relação criada pelos gregos, para Vitruvio, tornou-se sagrada; e será também objeto de estudo para os renascentistas.

Baseado no Humanismo, o Renascimento voltou todo seu pensamento ao homem. Criaram, portanto, um sistema intelectual caracterizado pelo conhecimento do homem sobre a natureza e pela rejeição das estruturas mentais impostas pela religião medieval. O homem renascentista queria realizar a natureza plenamente. A intenção do humanismo era desenvolver no homem o espírito crítico e a plena confiança em suas possibilidades, condições que the haviam sido proibidas durante a época medieval. O anseio pelo conhecimento e o espírito científico do homem renascentista provocaram uma verdadeira revolução

Revolução essa que já vinha se manifestando no fim do período da Idade Média, principalmente com a aparição inicial e crescente de uma burguesia urbana, que procurou se estabelecer e firmar seu poder também através da busca pelo conhecimento e por uma cultura que os ascendesse.

No Renascimento, há uma enorme crença nas leis matemáticas, onde seu uso se faz necessário para construir, justificar e dar razão às obras desse período. Para os renascentistas, a arquitetura apresentava-se como uma ciência exata, na qual cada elemento do edifício projetado, fosse no interior ou exterior, deveria pertencer a um mesmo sistema de quocientes matemáticos. Segundo Wittkower, esse sistema deveria adequar-se às concepções de uma ordem superior, apresentando-se relacionadas assim como as proporções de um corpo humano. "Assim como o homem é imagem de Deus e as proporções de seu corpo provêm da vontade Divina, as proporções da arquitetura devem abranger e expressar a ordem cósmica". (WITTKOWER, 1968, p.102). 
Principalmente Alberti e Palladio, em seus tratados, De Re Aedificatoria e I Quattri Libri, respectivamente, trataram da harmonia matemática entre as partes componentes de um edifício.

(...), para Alberti, na música se revelam os quocientes harmônicos inerentes à natureza. $\mathrm{O}$ arquiteto que se baseia nestas harmonias não estará transladando relações musicais à arquitetura, mas estará dando forma a uma harmonia universal que se evidencia na música. (WITTKOWER, 1968, p.111).

A ligação com a natureza se dava através do estudo rigoroso de suas partes, que, observando as relações entre si e com o todo, poderia se chegar à beleza dada pela perfeição divina. A beleza vinha da proporção, da harmonia (no sentido de relação entre as partes) e da multiplicidade de coisas criadas sob as mesmas leis matemáticas que também regiam a música, que, por sua vez, era baseada no estudo e na interpretação matemática (realizada pelos gregos) da natureza.

Pode-se dizer que a História da Arte, que descreve as teorias vivenciadas no Renascimento, nasceu em Florença, na Itália, como reflexo da intensa atividade intelectual ocorrida nessa cidade no final do século XIV e século XV. Tal atividade se dividia em duas vertentes, relacionadas entre si: as teorias das artes, com base na ciência, e o começo da história da história da arte.

Para conseguir consolidar esse espírito de renovação, os florentinos tiveram que vencer dois obstáculos: transformar o individuo medieval, de paciente para agente da história; e reverter a pouca consideração que se tinha pelo artista, herança da Antiguidade.

O homem da Idade Média não pensava em construir a história, em ser um agente da humanidade, pois para ele, os cristãos tinham de viver a história que Deus lhes desejasse.

A Idade Média herdou da Antiguidade o desprezo por aqueles que trabalhassem com as mãos, principalmente os artistas. Esse sentimento vinha dos romanos para com os gregos, já que a esses cabiam o trabalho manual, mesmo que fossem obras de arte, e àqueles estava reservada a arte da guerra, ou seja, nas palavras de Virgílio: "Romano, lembra-te de comandar o mundo. Tuas artes, ei-las: impor a paz, perdoar os vencidos e dominar os soberbos". (BAZIN, 1989, p. 05).

As artes conhecidas na Antiguidade se dividiam em duas vertentes: as servis ou mecânicas e as liberais. As artes servis correspondiam a todo o trabalho artístico manual, sem distinção entre seus objetivos. As artes liberais eram subdivididas em duas outras (que serão muito consideradas na Idade Média, em suas instituições de ensino): trivium e quadrivium. À primeira estavam reservadas as disciplinas de gramática, dialética e retórica; e a segunda eram a geometria, a aritmética, a astronomia e a música. Embora essa última fosse considerada uma arte (atualmente, enquanto o restante participa do campo da ciência), desenvolvida pela mão do homem, a música ganhou seu lugar nas artes liberais por ser julgada como decorrente da aritmética.

Pode-se dizer que as artes servis eram próprias dos escravos, o que justifica o seu desprezo, já que o escravo não era considerado um homem da sociedade, ou cidadão. Em 
contraposição, as artes liberais eram consideradas próprias dos homens cultos, que compunham uma minoria (muitas vezes, eclesiásticos).

Esse desprezo pelas artes mecânicas pesara por muito tempo sobre os artistas. Apenas quando conseguiram tornálas liberais é que nasceu a história da arte, já que também foram iniciadas as biografias dos artistas.

Pela pouca consideração aos artistas, devido à crença de suas origens serem de escravos, ou artesãos, que nada tinham de estudo, mas de prática, era normal o anonimato dos artistas medievais. Apenas, por volta do século XII e XIII é que começam a aparecer textos que discutiam a natureza do belo, com Santo Agostinho, Santo Ambrósio, São Boaventura e São Tomás de Aquino, sempre seguindo o platonismo e neoplatonismo. Além dessas fontes, o texto de Vitruvio, única herança escrita sobre as antigas obras arquitetônicas, também foi consultado na Idade Média. Os filósofos medievais acreditavam que a beleza das coisas materiais era própria da beleza invisível presente em Deus, único criador, e que por isso, os artistas deveriam imitar o mestre.

Os escritos mais ilustres da Idade Média eram livros de receitas e tratados técnicos, sem nenhuma intenção de indicar o passado, a história de seus homens. Ainda que tratassem de alguma técnica artística, era em caráter de missão espiritual, como se fossem enviados para apresentar a beleza que Deus emana, relacionado sempre a um mundo ideal, atemporal.

Bazin (1989) considera Filippo Villani como o primeiro historiador da arte. Apresentou em seu livro Líber de origine civitatis Florentiae et eiusdem famosis civibus, escrito em latim no começo do século $\mathrm{XV}$, a história das origens da cidade de Florença e a biografia de seus mais célebres cidadãos, o que não causa estranheza por ter vivido em uma civilização onde qualquer fato tinha a marca do gênio individual. No entanto, Villani relatou em seu livro apenas a vida de cinco pintores: Cimabue, Giotto, Maso, Stefano Fiorentino e Taddeo Gaddi; privilegiando, com isso, a pintura sobre as outras artes. De certa forma, exalta os pintores que retomaram a semelhança das coisas, em um súbito de retroceder à Antiguidade como tentativa de garantir uma continuidade e assim desenrolar um progresso na civilização que começava a aflorar. Para os homens do Humanismo, a Idade Média podia ser considerada um hiato entre a Antiguidade e o momento que se inicia, um entrave ao progresso que se imaginava para aquele período áureo.

As artes figurativas começam a se transformar em artes liberais, ou seja, ganhar força como ciências. Os artistas humanistas passam a reivindicar a pintura, escultura e arquitetura como artes liberais, pois antes do trabalho manual, próprio de sua expressão, o artista deveria realizar uma operação mental criativa (il disegno para os italianos).

A perspectiva, que gerou toda uma discussão específica, passou a garantir ao pintor uma base sólida científica, já a partir do século XV. Nesse mesmo século, a escultura uniu-se à pintura como mais uma arte liberal, devido ao seu conhecimento necessário da teoria das proporções do corpo humano. A arquitetura, assim que começou a se inspirar na Antiguidade, através de estudos, para realizar seus edifícios, passou também a fazer parte das artes liberais. 
Como forma de teorização e, conseqüentemente, divulgação e ensinamento da prática de arquitetura, pode-se destacar a marcante e fundamental presença dos tratados arquitetônicos do Renascimento, realizados por arquitetos do período. A aparição do tratado De Arquitectura, de Vitruvio, incentivou a produção desse tipo de texto durante todo o Renascimento. Pode-se atribuir a esses documentos uma grande importância na separação entre concepção e execução de arquitetura, teoria presente em todo o Renascimento. A figura do arquiteto torna-se fundamental nesses dois momentos, garantindo que sua obra saia do jeito em que foi concebida. Outro ponto de importância dos tratados renascentistas é a inicial definição do sistema gráfico de comunicação da arquitetura, até hoje empregado.

Leon Battista Alberti (1404-1472) foi um grande teórico e humanista do Renascimento. É sem dúvida o de maior domínio da cultura no Quattrocento. E será mais tarde substituído por Leonardo da Vinci, artista genial, conhecedor do saber técnico e da capacidade do homem sobre a natureza, e que realizou ou idealizou muitas invenções atualmente importantes.

Alberti apresentou as discussões do período e norteou a profissão de arquiteto na Renascença nesse seu tratado De Re Aedificatoria, de 1452. Essa obra apareceu como um manual de construção de arquitetura no período, revelando como deveria ser a profissão de arquiteto e seu método de trabalho no Renascimento. $\mathrm{O}$ arquiteto deveria ser completo, conhecer um pouco de tudo, assim como todos os homens do Renascimento, pintores, escultores, etc.

O tratado de Alberti procurou revisar e suprir algumas deficiências presentes no tratado de Vitruvio. Por ter sido escrito aos poucos e revisto ao longo de sua concepção, o tratado de Vitruvio tornou-se muito eclético e descosturado, no qual muitas vezes, teorias contraditórias foram colocadas como consonantes. Assim como uma preocupação geral em todo Renascimento, Alberti procurou estabelecer em seu tratado uma visão unitária da arquitetura, contrapondo-se a Vitruvio. Para Alberti, aquele tratado visava a beleza em todas as coisas e não exclusivamente a arquitetura. No Renascimento, há uma enorme racionalização do texto de Vitruvio. Esse colocou os motivos das escolhas para a elaboração da arquitetura, já Alberti definiu o objeto Arquitetura, segundo seus elementos de concepção. Portanto, a partir do Renascimento há um tratado que constitui um objeto sem se afastar do repertório formal clássico. Constitui o objeto e uma concepção de Arquitetura muito bem amarrada, estruturada. Esse é o elemento novo em relação a Vitruvio

Alberti foi um grande arquiteto em seu tempo. Esteve muitos anos em Roma, onde conseguiu um emprego na Cúria de 1431 a 1464, e era protegido pelos papas humanistas Nicolau V e Pio II. Fez sua arquitetura em Mântua e Florença, onde exerceu mais como mentor do que propriamente executor. Ao longo de sua vida, em cada visita a Roma atinha-se a medições de monumentos para levantar uma planta da cidade antiga.

Por volta de 1433-34, escreveu o tratado De família, no qual expunha o seu ideal: "a ordem humana corresponde à ordem universal, que a engloba, e o dever de cada um é tornarse um 'homem universal', possuidor de todas as ciências e que procura realizar em si o equilíbrio que haverá de assegurar sua felicidade". (BAZIN, 1989, p. 14). 
Escreveu sobre todas as artes em seus tratados: De statua, conhecido em 1568, em versão italiana; Da pintura, de 1450, e Da arquitetura, conhecido por De re aedificatoria, de 1485, publicado após sua morte.

Deu primazia à arquitetura, porque esta era para ele essencialmente a arte da vida social, que permite ao indivíduo o desabrochar de seu ser no quadro doméstico e regula a vida harmoniosa dos cidadãos; e, como para os costumes e a vida, éo antigo que deve servir de modelo. (BAZIN, 1989, p. 15).

A noção única que aparece em todos os tratados do século $\mathrm{XV}$ é o de que o artista deveria imitar a natureza, para alcançar a beleza, a qual deveria ser obtida pela escolha do que parecesse mais belo segundo a Idéia, conceito correspondente às teorias platônicas.

A noção de perspectiva, a arte de representar o mundo em profundidade, é bem simbólica do olhar dirigido para frente, para o futuro, substituindo essa visão da Idade Média em que o mundo se desdobrava perante o artista como o teatro dos mistérios, onde tudo se apresentava no mesmo plano. (BAZIN, 1989, p. 15).

A semente do ensinamento de Alberti germinou totalmente após 1500. Todavia mesmo que não soubesse nada dos métodos de representação de Brunelleschi e de Alberti, o seu efeito era legível já nas mudanças da arte toscana a partir de 1430 . O reflexo mais direto se encontra talvez no escultor florentino Filarete (1400 ca.- 1469 ca.). Filerete referia-se a

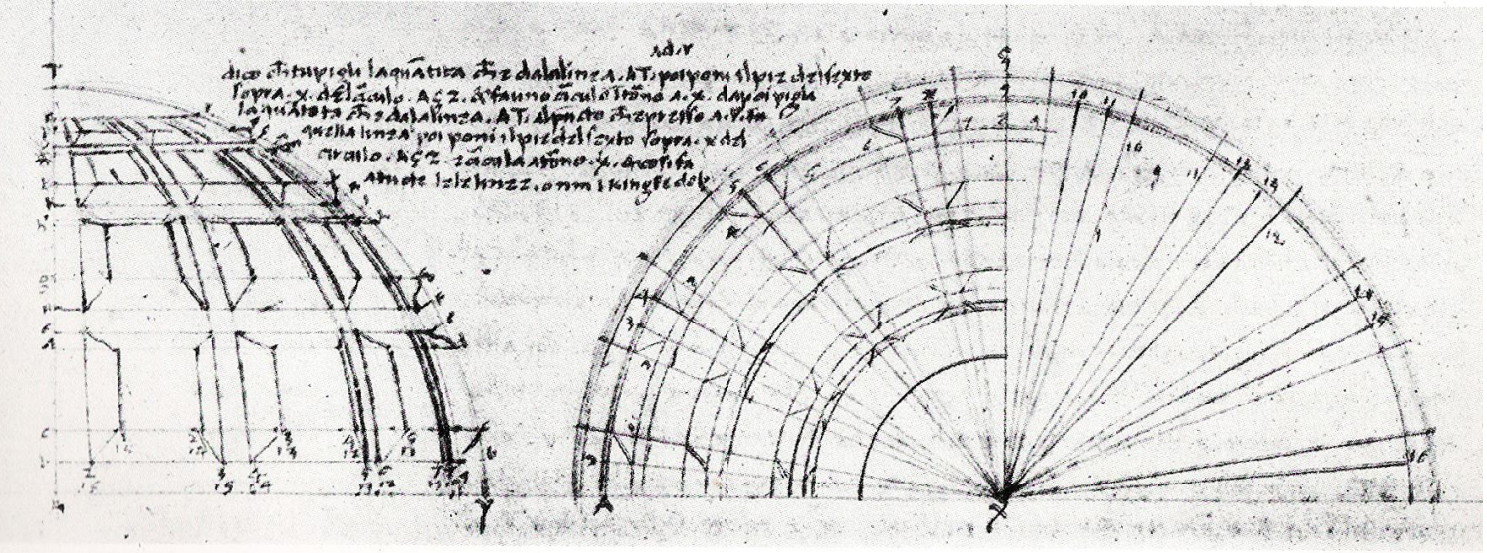

Figura 38 - Piero della

Alberti em seu tratado, em seus textos, mostrando claramente

Francesca. Vista em perspec-

tiva de uma cúpula. (MILLON

e LAMPUGNANI, 1994,

p.111).

sua influência. Em seu tratado, Filarete procurou convencer seus patronos da Itália do Norte sobre a superioridade do estilo renascentista florentino frente ao estilo gótico da Idade Média.

Bramante (1444-1514) era formado no círculo de Piero della Francesca, de Melozzo da Forlì e de Mantegna, onde acabou conhecendo Alberti, que virou seu maior inspirador. Como os três precedentes fundadores da arquitetura renascentista, Giotto, Brunelleschi e Alberti, também Bramante se aproximou da construção indiretamente passando através do espaço pictórico. O seu presumível mestre, Piero della Francesca, por volta de 1480, seguindo os ensinamentos de Alberti, havia fornecido no seu tratado De prospectiva pingendi indicações detalhadas sobre a representação perspéctica da arquitetura.

Nos “anos romanos" de Bramante, isto é, no período compreendido entre 1499 a 1514, poucos desenhos foram conservados. Segundo Vasari, Bramante se dedicou em um primeiro momento ao estudo do antigo, que até agora havia conhecido somente através de Brunelleschi, Alberti e os seus outros mestres. Com rapidez se apropriou não só de ordens antigas e da linguagem antiga formal, mas também dos antigos sistemas e tipologias ou do ensinamento de Vitruvio e Alberti, 
o que pode ser testemunhado em seus edifícios dos primeiros anos de sua atividade como arquiteto: o Tempietto, Palazzo Caprini e o Cortile Del Belvedere.

A primeira monografia escrita na arte foi dedicada a Brunelleschi, e atribuída a Antonio di Tuccio Manetti (14231497), um famoso matemático, perito durante a construção do Duomo da Catedral de Florença, e que, conseqüentemente, teve bastante contato com Brunelleschi. Para Manetti, Brunelleschi corresponde na arte da arquitetura, em importância ao retorno ao Mundo Antigo, o mesmo que a Giotto na pintura. Esse texto, apesar de conhecido apenas em 1812, foi utilizado por Vasari, para o seu livro, de biografias, Vidas.

O livro conta que: seguiram seu estilo, retratando artistas contemporâneos e de sua região. Um cronista desconhecido relatou a vida de 14 artistas florentinos (I XIV uomini singhulary in Firenza Del 1400 innanzi), entre eles o arquiteto Brunelleschi, os escultores Donatello, Ghiberti, Luca Della Robbia, os pintores Masaccio, Fra Angélico, Paolo Uccello, Filippo Lippi.

Cristoforo Landino também identificou uma lista dos artistas florentinos, julgados por ele mais eminentes, começando com Cimabue e terminando com Rosellini, em seu Comentário sobre Dante, publicado em 1481.

Apesar de Florença ser o grande pólo artístico da Itália nesse período, algumas outras cidades e regiões italianas também relataram os feitos de seus ilustres cidadãos. Bartolomeu Faccio (1403-1457), em Homens Ilustres, texto original em latim, descreveu interessantes testemunhos sobre artistas da corte de Nápoles, na época do rei Afonso. Entre eles, citou pintores como Gentile da Fabriano, Pisanello, os flamengos Jan van Eyck e Rogier van der Weyden (considerado aluno do anterior); como escultores importantes Lorenzo e seus filhos Vittorio Ghiberti, Donatello, e outros artistas toscanos.

E em 1494, surgiu a Crônica rimada das empresas do duque Frederico de Urbino, escrito por Giovanni Santi (pai de Rafael), que vivia na corte de Urbino. Nessa obra foram enumerados os pintores e escultores da Toscana, Vêneto e da Itália central, e ainda de alguns outros lugares (como van Eyck e van der Weyden), consolidando, portanto, a lista mais completa de artistas do período.

No século XVI, o pólo artístico de Florença se deslocou 
para Roma, sob os pontificados de Julio II e Leão X. Nesse momento, as figuras mais ilustres tornaram-se Bramante, Rafael e Michelangelo, que dando continuidade ao pensamento clássico já teorizado no século anterior, aplicaram sua expressão na nova igreja de São Pedro e do Vaticano reconstruído.

Dificilmente um século ou período se encerra em uma data certa; toda aquela confiança empregada pelos humanistas em si mesmos, de serem os pioneiros de uma nova civilização em oposição ao período das "trevas" (Idade Média), abalouse e teve seu fim por volta de 1530, ou seja, meados do período Cinquecento.

Em 1527, o saque de Roma estremeceu a fé dos italianos. Por três meses, Roma (Cidade Eterna ou Santa), cidade dos imperadores e sede da igreja italiana, ficou à mercê dos saqueadores estrangeiros, composto em grande parte por hereges. Nesse período, os romanos viveram um constante terror. Os historiadores modernos nomearam o período que se iniciou após esse saque de Maneirismo, no qual foi gerada uma inquietude intelectual.

Esse sentimento de angústia que se instaura no Maneirismo muito provém da revolta dos artistas de estarem imitando os imitadores da natureza. Isso quer dizer que, da mesma forma que o princípio do período anterior (Quattrocento) era a imitação da natureza, nesse momento, chegando ao ideal proposto, a ordem era a imitação de seus mestres. Portanto nessa inquietude, os artistas sentindo sua alma se rebelar a essa sujeição, empregaram sua expressão pessoal à obra, distorcendo-a, deformando-a como se fosse um desafio. Isso se refletiu em todas as artes, inclusive arquitetura,

com suas formas serpenteantes.

Assim como o início do "novo mundo", foi em Florença que nasceu o maneirismo. Aos poucos foi cedendo sua liderança a Roma, da qual saiu seu mais ilustre artista: Michelangelo Buonarroti. Criado pelos florentinos, o maneirismo se espalhou por toda Itália, ganhando força principalmente em Bolonha e Parma. A arte passou a se construir sobre a própria arte e não mais sobre a natureza.

Quando esse sentimento de um passado glorioso tomou conta dos italianos, Vasari escreveu seu livro Vite (Vidas), na tentativa de não esquecer ou até mesmo reviver os artistas que criaram e elevaram a arte italiana, ou seja, os pais do Renascimento. Segundo Bazin (1989), foi nesse momento que nasceu a história da arte, a partir da história de Florença, de seus artistas.

A paixão trazida à pesquisa do passado numa espécie de ressurreição dos mortos traduz sempre algum instinto de fim de civilização, como se observa em nossa época, na qual o menor testemunho deixado pelos homens de outrora, quando se vê ameaçado pelas obras dos homens de hoje, suscita protestos como se o patrimônio da humanidade devesse ser feito da totalidade daquilo que os homens produziram. (BAZIN, 1989, p. 21).

Vasari nasceu em 1511, em Arezzo de Pallastra, onde conheceu as bases do Humanismo. Em 1521, foi para Florença continuar seus estudos, onde Michelangelo lhe ensinou a arte do desenho e da pintura. Em seu manuscrito deixa claro que, para ele, a Itália tinha somente dois centros culturais: Florença 
e Roma, que a sucedeu.

Vasari afirmava em seu livro Vidas que a pintura, a escultura e a arquitetura eram filhas de um mesmo pai, a arte do Desenho.

Essa obra de Vasari apresentou-se em duas edições, a primeira em 1550, dedicada ao grão-duque Cosme I e impressa por Lorenzo Torrentiano, um editor flamengo, residente em Florença. A segunda edição saiu em 1568, impressa por Jacopo Giunti, em Veneza, trazendo alguns acréscimos, principalmente de artistas ainda vivos em seu tempo, além de outros provenientes de outras cidades, como por exemplo, Veneza, lugar estudado por Vasari em 1566; acrescentou ainda uma autobiografia, a primeira da história.

Vasari, atento à elevação das artes figurativas e arquitetura a condição de ciências, nas artes liberais, procurou colocar os conhecimentos necessários a cada arte antes de iniciar sua biografia. Para isso, introduziu uma explanação intitulada Introdução às três artes do desenho, arquitetura, escultura e pintura. Nesse momento, Vasari, indiretamente separou as artes maiores, das quais tratou em seu livro, das artes menores, que pouco abordou, e considerando-as ainda artes mecânicas, portanto servis: entalhos, medalhas, camafeus, ourivesaria, mosaico, etc
A obra é mais densa, tem mais unidade. Ao querer completar seu livro por um acréscimo documentário, Vasari lhe alterou de certa forma harmonia. (BAZIN, 1989, p. 31).
${ }^{1} \mathrm{O}$ termo maniera muito utilizado por Vasari em seu características pessoais da vida de seus artistas e, em geral do período, foi substituído há pouco tempo pelo vocábulo estilo.

dizer melhor, renascimento" discurso, relacionado às construção sem ordem, sem coerência, com tratamento livre de suas formas decorativas, entre outras observações.

A concepção histórica da arte, de Vasari, era uma teoria da evolução, em que seu progresso deveria passar em três estágios pré-determinados:

[o primeiro] estado primitivo em que as três artes se acham na infância e existem, por assim dizer, apenas em 'esboço grosseiro' (abozzo); [o segundo], estado de transição, comparável à adolescência, em que se fizeram progressos consideŕais, masque não pode ainda atingir consider a absoluta peresço; e fin de plena maturidade, no qual a arte 'subiu tão alto que se pode temer uma recessão em lugar de esperar maiores progressos'. (PANOFSKY, 1979, p. 281).
Vasari definiu em seu livro o que seria a maniera ${ }^{1}$ greca (bizantina), a maniera tedesca (gótico) e a maniera moderna, que significava o combate às duas primeiras para elevar a arte, ou e depois, Giotto começarem a contestá-la, iniciando um novo período conhecido por Renascimento (primeira vez empregado por Vasari) - "restaurazione delle arti e per dire meglio A maniera greca esteve presente na Itália até Cimabue,
Se a edição dita Giustiniana [2a . edição] nos traz um quadro mais completo e colorido da arte considerar a Torrentiniana [1 $1^{\text {a }}$. edição] como superior do ponto de vista literário. A linha de evolução da arte que Vasari quer ressaltar émais clara aqui que na edição mais compacta de 1568 
A essa primeira idade, Vasari exemplificou colocando Cimabue como pintor e Arnolfo di Cambio como arquiteto. Considerava ambos como precursores de um período importante e belo que se iniciou no final do século XIV; e conferiu-lhes importância por estarem apresentando melhorias ao sistema em vigência, a "maneira tedesca" (gótico).

Após esses três estágios, Vasari ainda arriscou um quarto, mais presente na $2^{a}$ edição, que era o declínio já instaurado na angústia de seus artistas contemporâneos.

Ainda que a vontade fosse sempre de aplicar a maniera moderna, os italianos, por vezes, depararam-se com edifícios em construção, inicialmente ao estilo gótico, o que gerava um problema de unidade estilística, comprometendo o princípio de conformità, definido por Alberti como uma tentativa de não justapor elementos dissonantes, para garantir a uniformidade da obra - o que realmente interessava para a beleza do edifício. Ainda que muitos arquitetos italianos (dependendo da região em que estavam inseridos) não conhecessem claramente o estilo gótico, ao seguir essa regra, acabavam terminando a obra como um gótico puro, muitas vezes, mais "genuíno" do que os realizados conscientemente pelos arquitetos nórdicos.

Para os italianos, esse problema de conformità poderia seguir três caminhos em sua execução: sobrepor um revestimento "moderno" à estrutura existente; seguir a obra com um estilo goticizante; ou ainda, alternar entre as duas possibilidades, sempre visando a uniformidade geral da obra.

Esse primeiro método pode ser visto na obra de Alberti, no templo Malatestiano (S. Francesco) de Rimini; nos conselhos de Sebastiano Serlio, para a "modernização" dos palácios Figuras 39 e 40

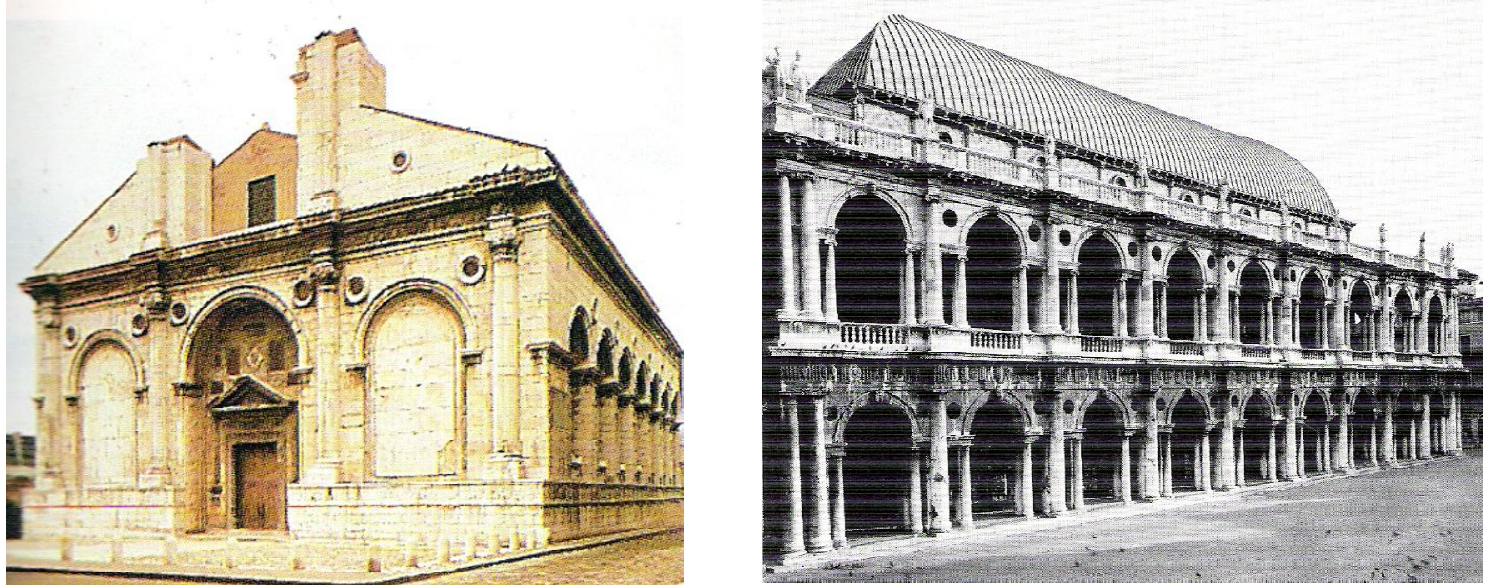

Figura 39 (acima) - Leon góticos; e em algumas obras famosas como na remodelação da Battista Alberti. Fachada do Santa Casa de Loreto, de Bramante (comentada por Andrea Templo Malatestiano de LAMPUGNANI, 1994, p.83).

Figura 40 (direita) - Andrea Palladio. Basílica de Vicenza, iniciada em 1549. (LOTZ, 1998, p.153)

Quanto ao segundo método, pode-se citar a passagem em que Francesco di Giorgio Martini e Bramante propuseram em seus projetos e memoriais que a construção do tiburio (torre principal) seguisse o estilo adotado na estrutura da Catedral Figura 41 de Milão.

A terceira solução pode ser exemplificada através da fachada de Santa Maria Novella de Alberti, de 1455 aproximadamente, além do modelo do projeto proposto por Gherardo Silvani para o concurso da fachada da Catedral de

Figura 42 Florença, no qual o arquiteto colocou motivos góticos na sua composição, como por exemplo: as torres laterais octogonais, como referência ao campanário existente ao lado da catedral; a balaustrada composta de hexafólios no segundo pavimento; pilastras incrustadas ao lado de outras caneladas; e o símbolo

Figura 43 incrustado no frontão

Seguindo uma solução gótica para edifícios de estrutura já iniciada em estilo gótico, os arquitetos apenas endossavam o estilo. Quando podiam seguir seus próprios 


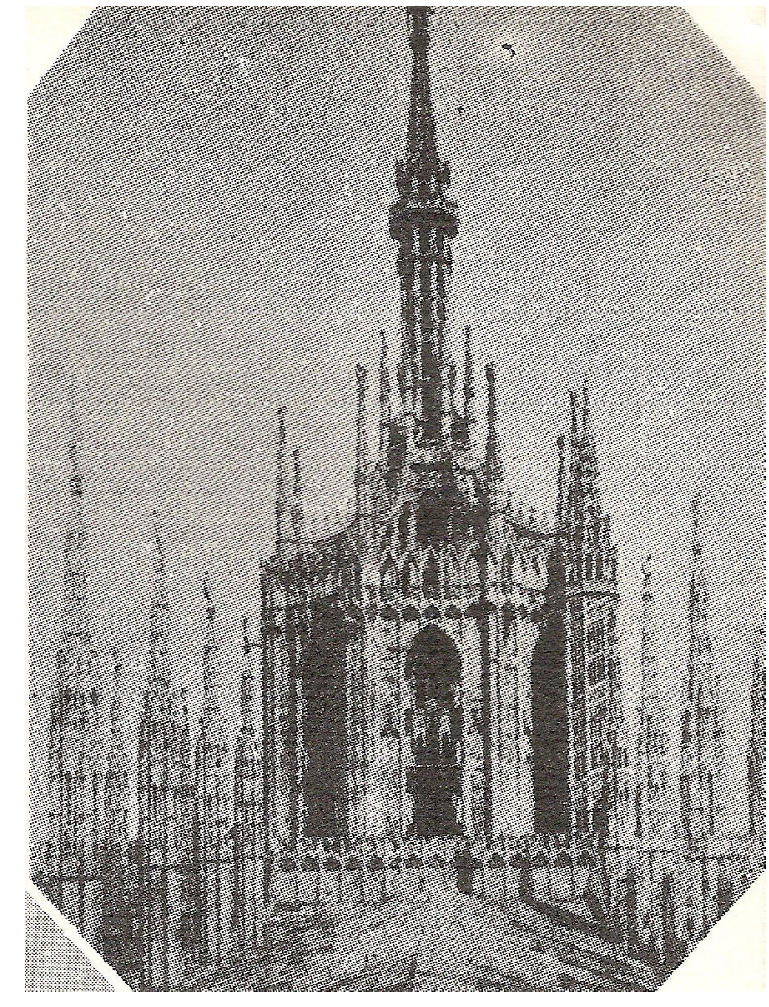

projetos, optavam por fazê-lo à "maniera moderna". Às vezes, os mesmos problemas, como a realização de lanternim em catedrais já em construção, podiam seguir diferentes soluções, ora optando pela unidade da construção, ora pela conjunção de estilos, feita de forma coerente, sujeitando-se ao princípio da conformità.

Na catedral de Florença, o lanternim proposto por Brunelleschi, em 1446, através de pilastras coríntias, claramente clássicas, disfarçava a conformação de pilares compostos góticos. Acima desses pilares, as volutas espirais, símbolos de força, transformavam em clássica a estrutura de arcobotante tipicamente gótico.

Pode-se comparar o tibúrio da Catedral de Milão com o Duomo da Catedral de Florença, em relação à sua identidade com o restante do edifício. O tibúrio de Milão foi executado de "maniera moderna" em sua estrutura (prismas octogonais encaixados entre si), com motivos góticos em sua ornamentação
“Silvani, então, produziu este modelo, compondo-o de duas ordens; e nos cantos propôs construir duas torres redondas, semelhantes a campanários, não apenas como um traço terminal do sistema gótico, com o qual a igreja é incrustada mas também para evitar um súbito afastamento do antigo estilo". (PANOFSKY, 1979, p 258).
Figura 41 - Catedral de Milão. Tibúrio. (PANOFSKY, 1979, p.257).
Figura 42 - Gherardo Silvani. Modelo para a fachada da Catedral de Florença. (PANOFSKY, 1979, p.263).

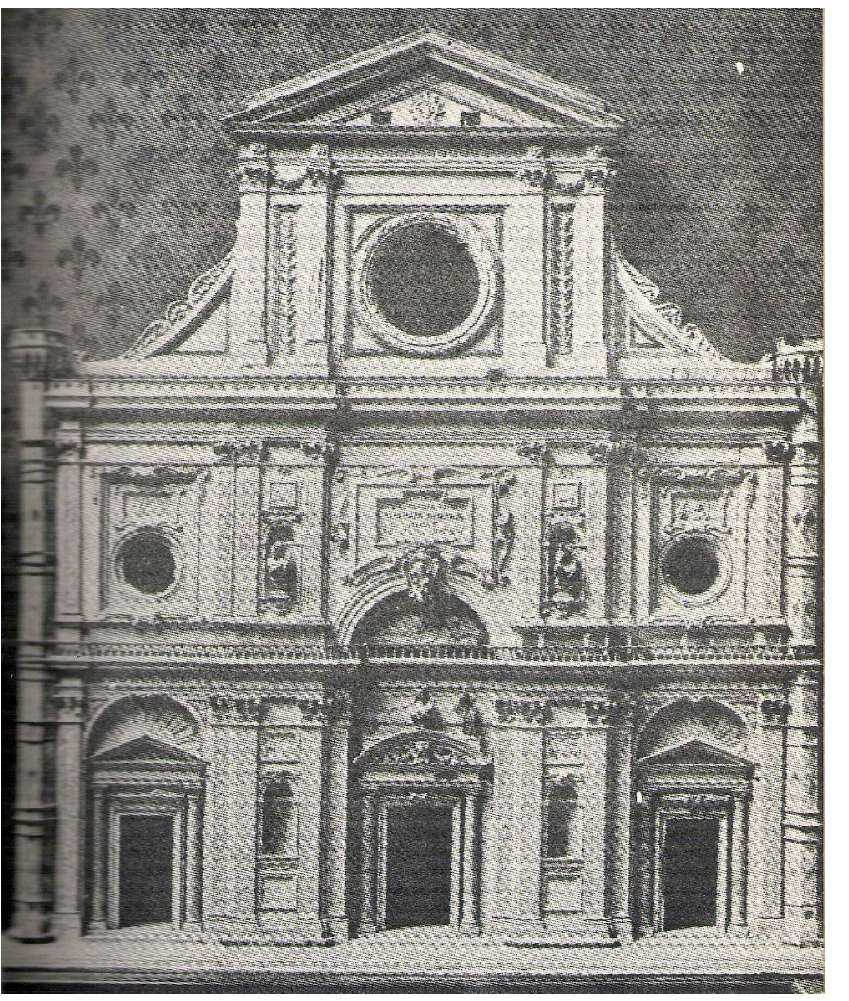

externa; ao passo que o domo de Florença tem sua estrutura com essência gótica, mas aparência "moderna", ou seja, clássica. Essa diferença pode ser explicada pelo fato de estarem em regiões diferentes da Itália. A parte norte da Itália sentia-se mais próxima do espírito que rodeava a arquitetura gótica, enquanto na região da Toscana, principalmente em Roma pouco se via dessa herança da Idade Média. Essa discussão entre as regiões vai além da disputa de gostos, chegando a refletir os antagonismos culturais, sociais e políticos existentes na Itália.

Bolonha considerava mais fácil honrar Dürer, um teórico alemão, do que os teóricos de Roma e Florença, como Michelangelo e Rafael. E essa divergência se refletia, muitas vezes, na própria arte: em cenas de nobres, ao fundo era possível identificar edifícios de estilo renascentista, ou clássicos; e em cenas do povo, era comum encontrar o estilo gótico.

Essa discussão entre a melhor forma de terminar um 


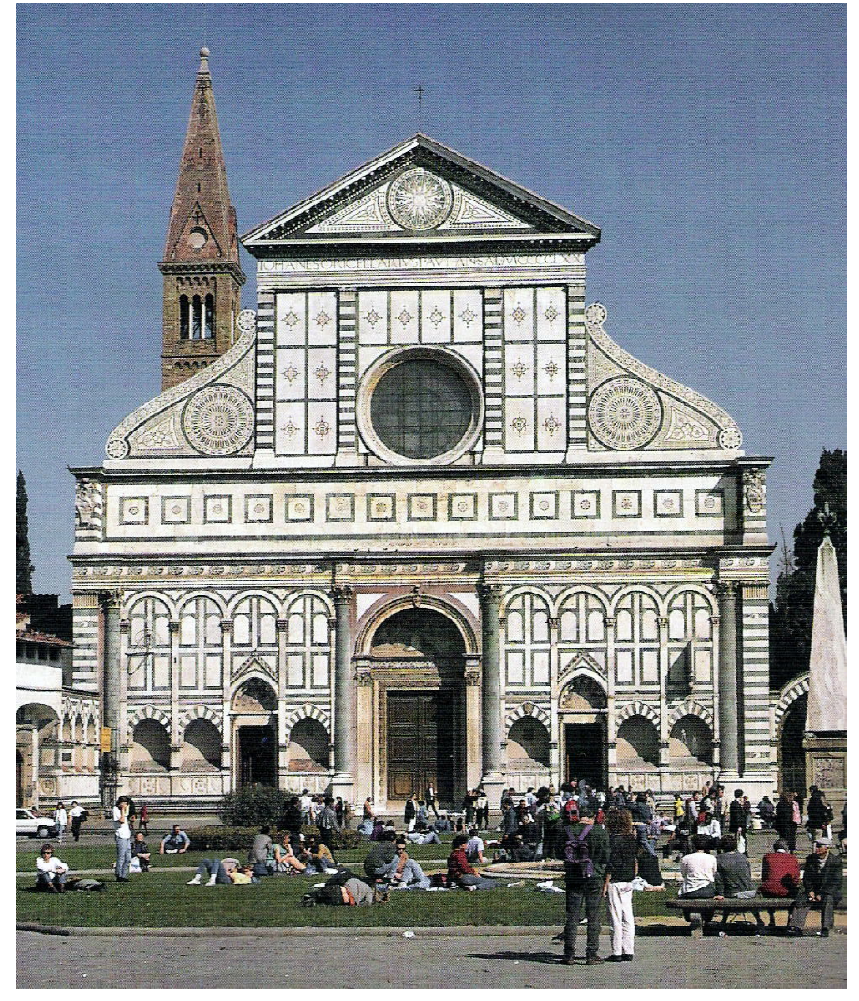

edifício iniciado em estilo gótico, apresentou seu momento mais crítico nos planos para a fachada da catedral deS. Petrônio, em Bolonha. Foram feitos três tipos de projetos: um para dar continuidade ao estilo gótico, outro para unir o gótico ao clássico, e mais outro que tornavam a igreja em estilo clássico. Essa querela somente finalizou com um memorial do arquiteto milanês Pelegrino de' Pellegrini, no qual defendia a pureza estilística. Para ele, deveria haver uma remodelagem total da igreja ao estilo clássico, que era a única forma de chegar à beleza. Porém, se os bolonheses ainda sim defendessem a continuação do gótico, esse deveria ser seguido severamente para não haver mistura entre as ordens.

Já nesse momento a pintura, escultura e arquitetura não eram mais consideradas artes mecânicas. E para reforçar essa afirmação, os artistas não se organizavam mais em corporações de ofícios, mas em academias, afirmando sua qualidade intelectual. Embora as primeiras academias do século XV tenham sido filológicas - estudo da língua grega e de filosofia, no século XVI houve uma grande disseminação de academias por toda a Europa, incentivada por grão-duques que queriam ver a aristocracia ociosa envolvida com obras literárias ou artísticas para garantir a vigilância de suas opiniões e mantêlas longe do poder.

O objetivo das academias era de assegurar o nível das artes e prover seu ensino. Nesse momento, os artistas não mais se formavam aos pés de um mestre, mas através das academias, onde tinham o exemplo de diversos mestres.
Figura 43 - Alberti. Santa Maria Novella, Florença, 1458 (HEYDENREICH, 1998, p.39).
Em 1562 Vasari solicitou a proteção do grão-duque para a criação da Accademia Del Disegno, em Florença, a primeira academia artística bem estruturada. Foi composta por trinta e seis artistas escolhidos pelo grão-duque, tendo por objetivo ministrar o ensino das artes.

Em 1593, foi aberta em Roma a Accademia di San Luca, reunindo pintores, arquitetos e escultores, sob o signo de um instituto de ensino, como uma verdadeira universidade de artes.

Como citado no início do capítulo, todas as artes, ou melhor, toda a teoria de estética, que passou a reger as representações artísticas, inclusive a arquitetura, no Renascimento, está baseada em uma teoria das proporções. A proporção, entendida como uma relação entre elementos ou objetos, remete-se a tempos bem remotos.

O modelo tridimensional em arquitetura também estava inserido nessas teorias, não só em sua execução, mas como elemento de composição dessas discussões. Dessa 
forma, consideramos interessante aprofundar um pouco mais sobre as premissas da teoria das proporções, não só pensando na criação e representação do modelo, mas também na teoria da perspectiva, que será apresentada após.

Pode-se dizer que a teoria das proporções tem algumas subdivisões, que estão relacionadas com os seres que a elas se relacionam, isto é, em diversos momentos da história da arte, a representação aparece pautada segundo uma proporção, ora com as medidas humanas, ora com figuras geométricas, ora com aritmética, e etc. Tentaremos, nas próximas linhas, apresentar as proporções que eram vigentes em cada período, na tentativa de mostrar em que elementos a sua arte estava pautada.

A teoria das proporções humanas sempre esteve presente na arte figurativa, e mais tarde também na arquitetura, apresentada de forma objetiva (antropometria) ou técnica (teoria das construções).

Os egípcios desenhavam uma malha ${ }^{3}$ precisa de quadrados iguais em suas pedras ou murais, quando desenhavam figuras humanas ou animais. Empregavam essa técnica com o objetivo de auxiliar na construção do desenho, como, por exemplo, ao representar uma figura humana (cabeça e pernas em perfil e tronco em elevação frontal), sabiam que na primeira linha horizontal deveria estar o tornozelo da figura e na sexta linha, o joelho. Essa forma de construir a imagem apresentava diferentes malhas para cada tipo de figura, como por exemplo, a imagem humana, que tinha um cânone preciso de altura de 22 unidades, ou seja, 22 módulos (quadrados). Essa afirmação pode ser comprovada ao observar um desenho preparatório que contém três diferentes elementos colocados

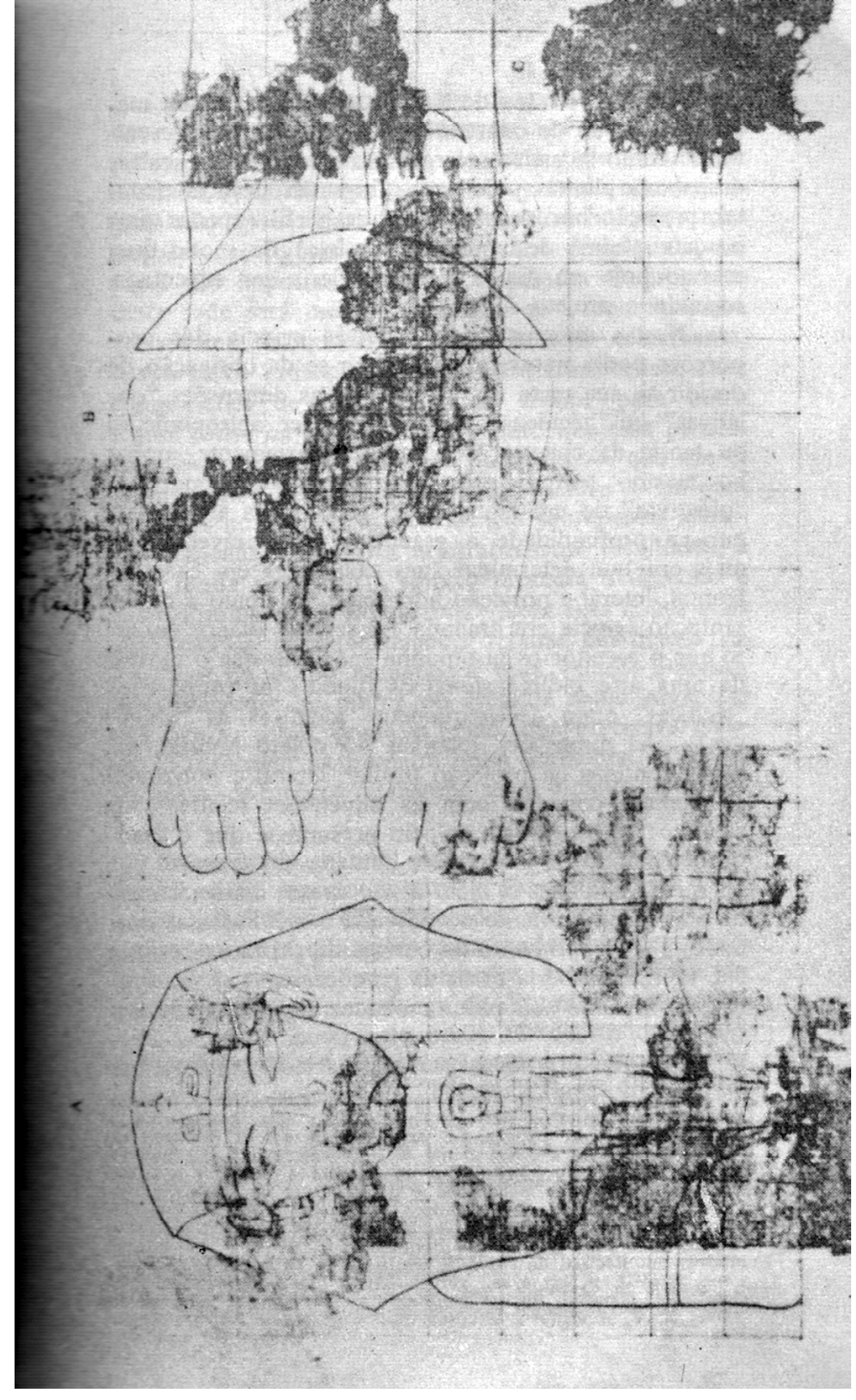

em composição: a esfinge com corpo de animal e cabeça humana, protegendo a deusa, figura humana. O corpo de animal apresenta-se sobre uma malha distinta da desenhada para a cabeça humana, seguindo um esquema conhecido como

Figura 44 Cabeças Reais; e a deusa, com a malha própria do corpo humano. Apesar de ser uma composição, os três elementos aparecem dentro de seus respectivos cânones de representação. 
Essa forma de representação egípcia confere ao objeto uma intenção de reconstrução da imagem, como uma apresentação imediata da figura, sem o simbolismo de recriar a realidade, mas de exprimi-la de maneira coerente com a espera da reanimação daquele mesmo mundo. Diferentemente da arte grega, onde há uma idealidade estética, com a mimesis, que pretendia simular uma vida própria, ideal.

O Egito e a Babilônia também apresentaram um sistema de proporção em sua arquitetura, no século III a.C., como reflexo da condição de estarem subordinados a uma ordem encontrada nas estruturas sociais desenvolvidas em suas civilizações urbanas, que eram baseadas em uma hierarquia bem organizada. Os sacerdotes eram os guias espirituais, portanto, os edifícios sagrados deveriam seguir a ordem por eles estabelecida.

Ao contrário da malha quadriculada do artista egípcio, onde a figura era inserida através apenas do estabelecimento de alguns pontos definidos (tornozelo, joelho, ombros), o grego começava seu desenho pela figura, dividida em tronco, membros e partes desses membros, tentando uma relação entre cada um e com o todo. Dessa forma, seguindo o chamado cânone de Policleto, que define relações entre os dedos, o dedo e a mão, essa e o antebraço e assim por diante (sistema das frações ordinárias, que será mais tarde adotada por Vitruvio como a relação presente na Antiguidade), o artista grego procurava relações não claramente construtiva, mecânica (malha fixa), mas de diferenciação orgânica.

A arte grega diferenciou as dimensões objetivas e técnicas da representação de figuras e considerou principalmente

(...) a mudança das dimensões como resultado do movimento orgânico; a perspectivação decorrente do processo visual; e a necessidade de corrigir, em certos casos, a impressão ótica do espectador através de ajustamentos 'eurrítmicos'. (PANOFSKY, 1979, p. 99).

A Grécia (das cidades-estado) apresentou uma diferença muito importante em relação ao Egito: uma nova classe formada por cidadãos livres iniciava uma investigação racional da natureza do universo, convertendo a sua conhecida matemática em teorias que interpretavam essa natureza observada.

Pode-se considerar Pitágoras o fundador das teorias da geometria. Aplicou seus métodos teóricos à natureza e descobriu que a estrutura do universo estava pautada sobre proporções e razões conhecidas. Uma de suas provas dessa afirmação era a relação observada entre o comprimento das cordas de um instrumento e as notas que delas derivavam, o que possibilitava, portanto, averiguar uma relação fixa e invariável presente na música.

Através do estudo do sistema harmônico grego da música, descrito pelas razões de 1:2:3:4, Pitágoras acreditou ter encontrado a harmonia universal que rege o mundo. Essa

4 Nesse momento necessário saber distinguir razão de proporção: razão a relação entre duas unidades, e proporção é a igualdade de razões entre dois pares de unidade (WITTKOWER, 1979). era a explicação geométrica do sistema harmônico (baseada no comprimento das cordas de um instrumento e o som por elas produzido).

Pitágoras e seus discípulos estudaram a escala musical grega e chegaram a três tipos de proporções ${ }^{4}$ : geométrica, onde 


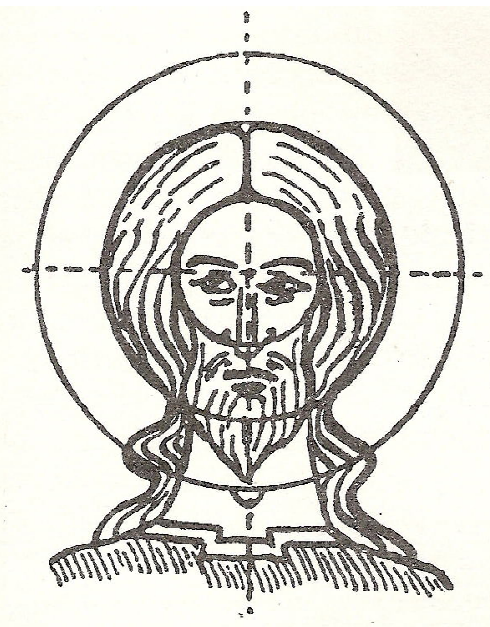

o primeiro está para o segundo, assim como esse está para o terceiro (1:2:4); aritmética, no qual o segundo termo excede o primeiro, assim como o terceiro excede o segundo (2:3:4); e harmônica, quando os dois termos extremos relacionam-se com o do meio, a partir de uma mesma fração de sua quantidade (6:8:12, onde 8 é $1 \beta$ de $6+6$, e é $12-1 \beta$ de 12).

Platão, em seu Timeo, expressou a matemática de Pitágoras e o misticismo matemático, por meio de um ilustre mito cosmológico, que seguirá sendo a base de muitos estudos, inclusive na Idade Média, que estava sob a influência de Aristóteles. No Renascimento, essa teoria pitagórico-platônica receberá uma nova intenção, com a busca pela ligação entre essa teoria e o cristianismo.

A arte medieval, embora tenha apresentado como característica geral a esquematização planimétrica, dividiu-se entre duas tendências em sua história: a bizantina e a gótica. A Figura 45 tendência bizantina baseava-se sobre o chamado "esquema bizantino dos três círculos", que procurava identificar a proporção entre as partes da cabeça do homem, tomando como elemento de composição primário a dimensão do nariz. Com
Figura 45- Esquema de Três Círculos da Arte bizantina e bizantinesca. (PANOFSKY, 1979, p.117).

isso, a anatomia do cérebro acabava muito distorcida, o que poderia deixar dúvidas quanto a representação frontal (ou superior?) do topo da cabeça. Ainda que a medida base fosse o comprimento do nariz (parte humana), a maior preocupação estava em racionalizar a figura, a partir de dimensões técnicas (ou seja, de técnicas de construção do desenho).

A tendência gótica era ainda mais radical. Estava relacionada puramente às formas geométricas, que eram colocadas sobre o desenho como um aramado independente. As linhas eram tidas mais como condutoras, do que mensuradoras do objeto representado.

Seguindo as teorias de Platão, podem ser encontrados estudos sobre figuras geométricas que definiram as bases da estética medieval: triângulo eqüilátero, isósceles reto, quadrado e o pentágono, além de suas derivações, o octógono e o decágono. Isso explica o motivo da maioria das igrejas medievais serem construídas ad quadratum ou ad triangulum, ou seja, a partir de quadrados ou de triângulos.

Casos importantes, que afirmam o uso desse sistema de proporções na Idade Média, podem ser verificados nos estudos sobre a catedral de Milão, e a igreja de San Petrônio, em Bolonha. Ambos seguem premissas que podem ser relacionadas com as teorias de Pitágoras (principalmente em relação ao triângulo pitagórico de lados relacionados a 3, 4 e 5); e Platão, inclusive contidas e devidamente explicadas no tratado de Vitruvio.

Essas relações eram utilizadas tanto na arquitetura, quanto na pintura, escultura e inclusive em objetos comuns. 
correntes, a interpretação cosmológica da teoria das proporções (presente na Idade Média), com o conceito clássico de simetria, que também significava proporção (relação entre as partes e dessas com o conjunto todo), como princípio fundamental da perfeição estética. Como procuravam fazer com que a escultura, pintura, arquitetura passasse de artes mecânicas para artes liberais, havia a necessidade de revestir a teoria das proporções de um significado metafísico, considerando que para a criação artística era preciso conhecer as proporções do homem, as quais correspondiam à harmonia preestabelecida entre o microcosmo e o macrocosmo, ou seja, o homem e o universo. Seus teóricos procuraram interpretar essa grande harmonia criada por Deus através das ordens numéricas platônicas. Para os artistas do Renascimento, toda obra deveria seguir essa harmonia universal, para alcançar a verdadeira beleza.

Essa afirmação toma força nos tratados renascentistas, como por exemplo, em Alberti, que se referia a Pitágoras, dizendo que o "os números pelos quais a concordância dos sons afeta prazerosamente a nossos ouvidos são os mesmos que agradam nossos olhos e nossa mente" (WITTKOWER, 1979, p. 530). Por essa razão, durante os séculos XV e XVI, muitos foram os tratados e obras que seguiram essas proporções presentes na escala musical grega.

As proporções do corpo humano foram relacionadas com a harmonia musical, reduzidas a princípios aritméticos e geométricos gerais, principalmente à seção áurea, além de atribuídas aos deuses clássicos. A observação da obra de Vitruvio proporcionou ainda a relação dessas proporções humanas com as partes das construções, empregando,

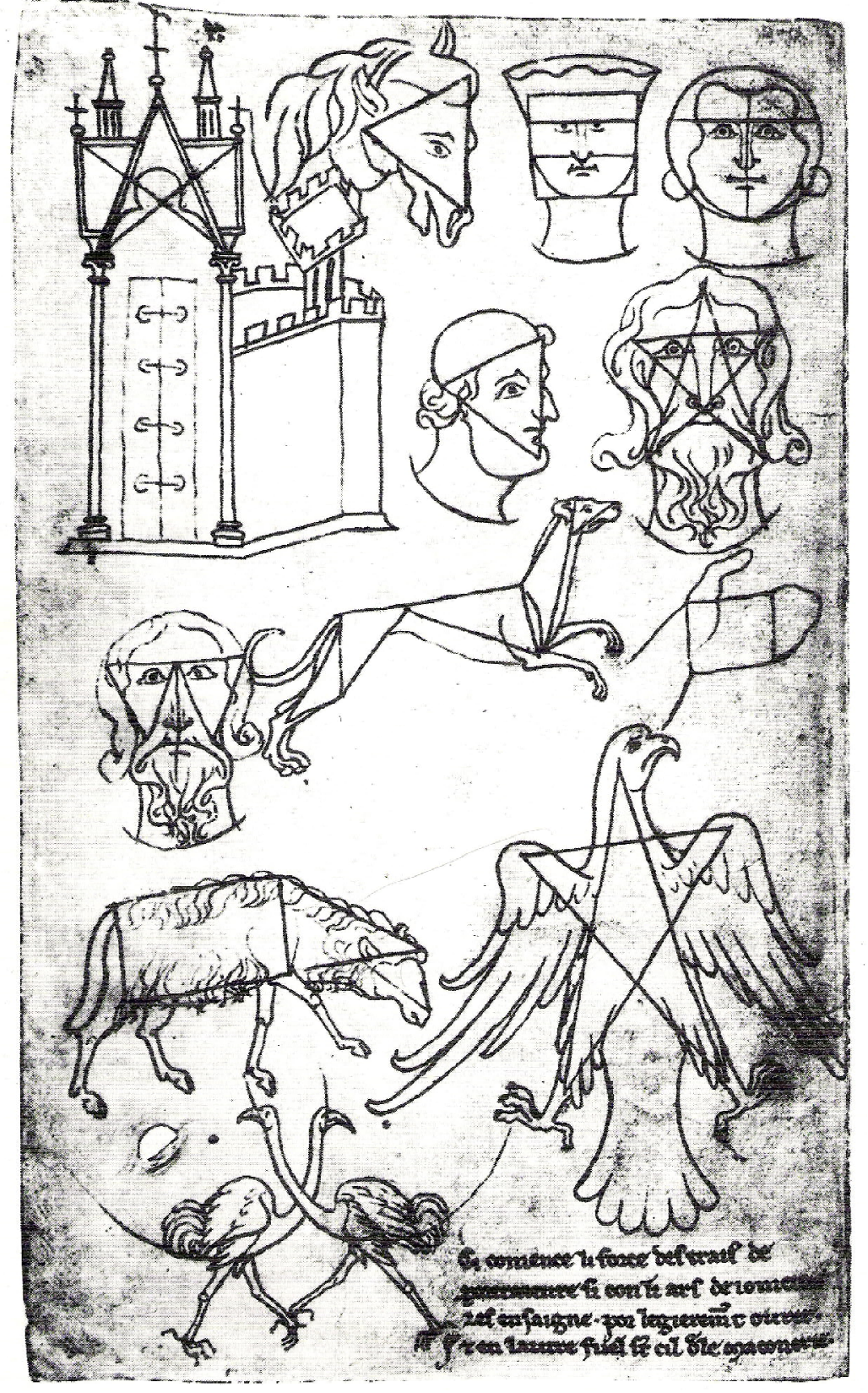

portanto, uma simetria arquitetônica ao homem, ou uma antropometria à arquitetura.

Pode-se dizer que dois grandes artistas renascentistas italianos foram responsáveis pela consolidação de novos passos da teoria das proporções além da época medieval: Leon Battista Alberti e Leonardo da Vinci, cada qual com sua importância e em seu momento, 
(...) deixaram de determinar o tipo ideal com base numa metafísica harmonística ou aceitando os dados de autoridades santificadas: aventuraram-se a arrostar a própria natureza e abordaram o corpo humano vivo com compasso e régua, sendo que de uma enormidade de modelos selecionaram aqueles que, a seu próprio juízo e na opinião de conselheiros competentes, foram considerados os mais belos. (PANOFSKY, 1979, p. 134).

Vale ressaltar aqui que a arte ocidental européia seguiu as duas proporções derivadas das teorias pitagórico-platônicas. A Idade Média se valeu da geometria dessas teorias, enquanto o Renascimento e os períodos clássicos escolheram o lado aritmético esses estudos. A proporção geométrica pode ser irracional, ou melhor, incomensurável, já que se apresenta através de relações entre figuras ou sólidos geométricos. A proporção aritmética dessa tradição está relacionada com a escala grega musical, onde números inteiros ou frações simples criaram sua base, ou seja, está baseada em razões Figuras 46 e 47 comensuráveis.

Essa predileção do Renascimento pela proporção aritmética pode ser justificada pelo fato de que no retorno à observação e medição da natureza, por seus artistas, implicava em encontrar relações métricas, ou seja, numéricas, entre suas partes; estudo que na proporção geométrica não era possível precisar.

Assim como não era possível imaginar uma relação diferente senão a métrica no Renascimento, devido à necessidade de conhecer e estabelecer a proporção entre as partes e entre essas e o corpo; na Idade Média era impossível pensar da mesma forma. Imbuída na lógica Aristotélica, a Idade

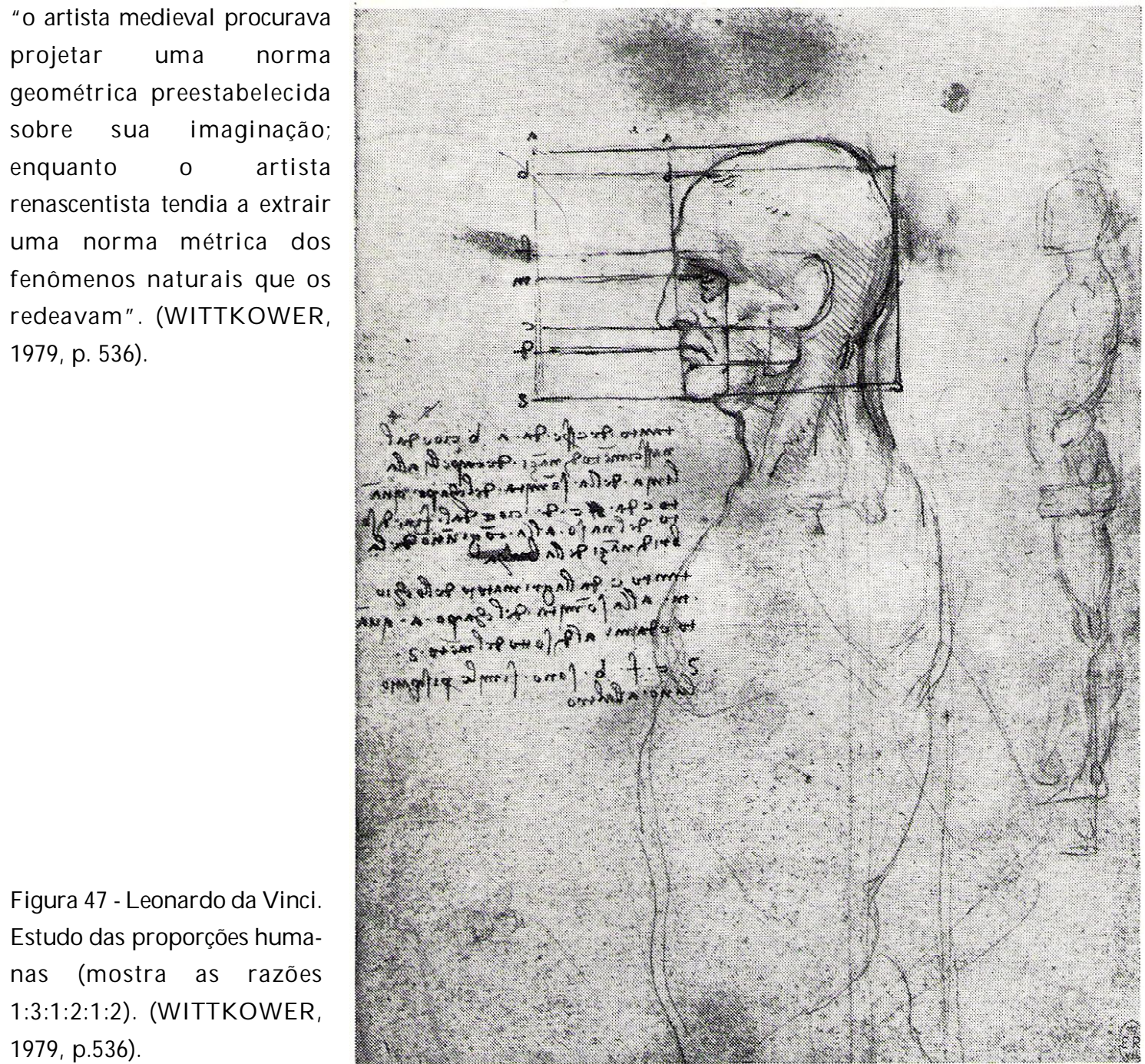

Média, apesar de conhecer as razões numéricas do conceito pitagórico-platônico sobre a escala musical grega, não consentia sua aplicação a nenhuma arte ou arquitetura. Muito pelo contrário, a procura pela verdade da forma, no período medieval, satisfazia-se com a geometrização da natureza.

Não se pode dizer que não havia relação métrica na Idade Média. Segundo Wittkower, essa relação poderia ser de ordem prática, como a relação entre o diâmetro de um pilar e sua altura, não interferindo no esquema geométrico proposto para o edifício. Já no Renascimento, a relação métrica era o princípio gerador do edifício, que garantiria a harmonia entre 
suas partes e com o todo. Por isso, os renascentistas adotam o sistema modular de Vitruvio, a fim de assegurar a relação numérica racional em toda a obra.

E ainda também não se pode dizer que o Renascimento não tenha se valido ou ao menos interpretado os sólidos e figuras geométricas de Platão, porém atribuindo diferente importância, e extraindo-lhes relações métricas, coerentes com o pensamento da época.

Assim como a teoria das proporções reflete o pensamento artístico, científico da arte, a perspectiva também o faz.

O desenvolvimento dos cortes em perspectiva (e depois sua "evolução", em perspectiva) e, em sua contraposição, dos cortes com projeção ortogonal, "estão intimamente ligados à concepção e à configuração do espaço interior" (LOTZ, 1985 , p.01).

Não existe um conceito de perspectiva somente. Os métodos que os homens elaboraram para "colocar em perspectiva" são tão diversos quanto as sociedades que a usaram ou usam-na. A perspectiva 'artificialis' teve origem no Quattrocento, isto é, no Renascimento italiano, e vinha justamente se opor à perspectiva 'naturalis', baseada na teoria da visão, presente durante a Idade Média.

Os primeiros estudiosos (pintores e arquitetos renascentistas) estavam bem conscientes de que as hipóteses necessárias para afrontar com sucesso tal problema (olho fixo e único, plano imóvel) contrastavam com as condições naturais da visão (binocular, com olhos e plano móveis)

Atribui-se a origem da perspectiva a Brunelleschi, embora sua teorização tenha sido iniciada mais tarde por Alberti, no tratado sobre a pintura, Da Pintura, de 1436. Na Idade Média, a perspectiva estava relacionada com ótica, ou seja, com as leis da visão, o que poderia ocasionar diversas formas de representar o mesmo espaço, considerando que a visão manifesta-se diferentemente em condições diversas.

A teorização da perspectiva no Renascimento procurava criar um sistema de representação único, ou seja "quando a imagem espacial percebida pela vista se identifica com a imagem espacial concebida pela mente". (ARGAN, 1987, p. 104).

O nascimento da perspectiva 'artificialis' implicou uma profunda transformação, que assinalou a passagem da cultura medieval à renascentista, na forma de considerar o espaço: de 'espaço dos corpos' a 'um lugar que existe antes dos corpos estarem nele, e por isso o desenho deveria ser definido antes (Pomponio Gaurico, 1504). Esta transformação foi importante na atividade dos práticos geômetras e na experiência adquirida nas medidas a distância.

Portanto, a perspectiva no Renascimento inverteu sua ordem de concepção com a da Idade Média. Na Idade Média, o artista concebia o espaço representado após sua apreensão visual, e no Renascimento, o artista apreende o espaço em sua mente, para depois percebê-lo com os olhos.

Todavia, inicialmente, prevalecia o entusiasmo gerado pela possibilidade de reproduzir o real, imitar a natureza, e ao mesmo tempo criar novos mundos. A vontade de poder (a 
centralidade) do sujeito era exaltada pela convicção de controlar as leis que governam o universo das aparências e de poder assim comunicar valores absolutos de harmonia ebeleza. Além disso, promover a escultura, a pintura, a arquitetura das artes mecânicas às artes liberais, através da racionalização e objetividade científica de métodos empíricos, tinha conseqüências não insignificantes na cultura do tempo, possibilitando o favorecimento de homens de poder, reconhecimentos sociais, ou retribuições elevadas. Somente em seguida, no tardo Renascimento (ou para alguns Maneirismo), com a crise do indivíduo, a atenção começou a se desdobrar sobre as deformações que as regras geométricas poderiam gerar.

Também em relação ao seu desenvolvimento, a perspectiva 'artificialis' se apresentou como um emaranhado indissolúvel de reflexões rigorosas e práticas empíricas nas quais, não só pintores, ilustradores, mas também engenheiros, geógrafos e militares contribuíram para elucidar. A criação de "máquinas de perspectivas" (usadas às vezes em levantamentos topográficos e em observações astronômicas) se enquadrava perfeitamente no complexo projeto cultural que agora se conhece por 'primeira revolução científica'.

E foi sobre esse terreno de exercícios impregnados de problemas concretos que se produziu gradualmente a cisão entre a perspectiva como fato puramente artístico (anterior ao Renascimento - uma tentativa de ver o objeto tridimensional no plano bidimensional) e perspectiva matemática (teoria das projeções).

A perspectiva matemática ${ }^{5}$, principalmente sobre seu uso em arquitetura, não apareceu de uma só vez. A constante
Figura 48 - Giuliano da Sangallo. Santa Sofia, Rom (LOTZ, 1985, p.43).

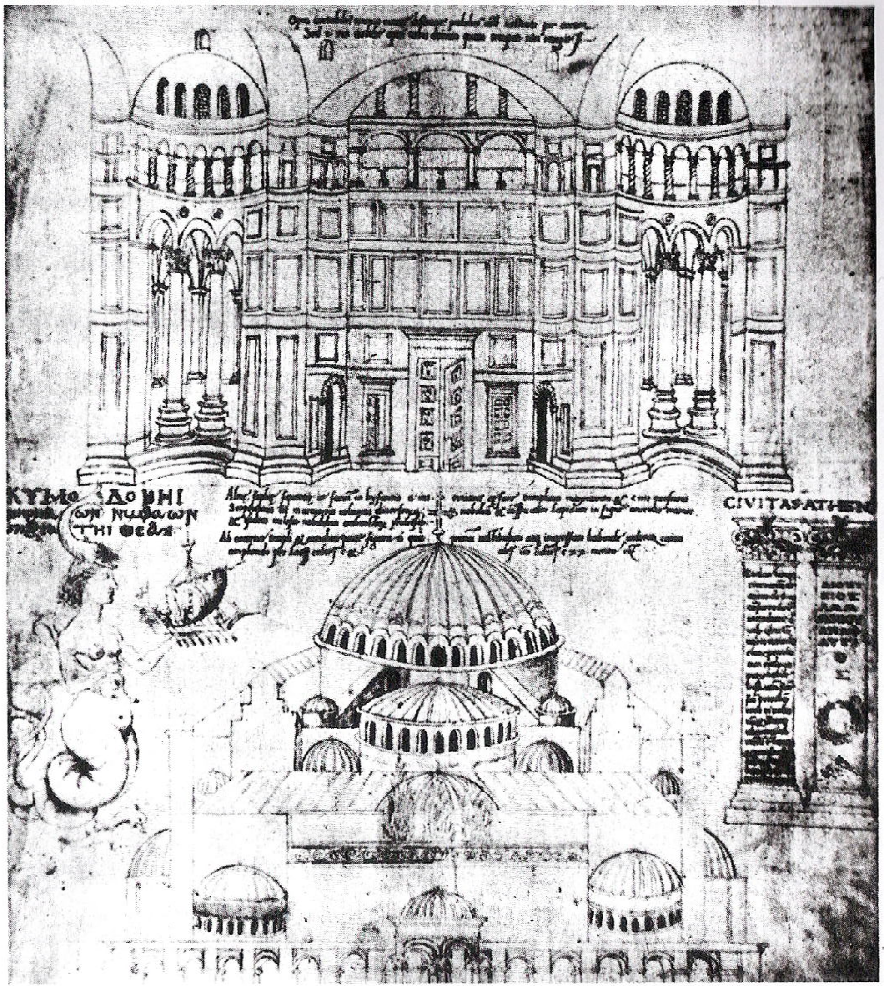

alteração na representação das seções foi sugerindo uma tridimensionalidade aos poucos. Inicialmente foi empregada uma pequena distorção visual na representação de vistas, tendendo para um ponto de fuga, para empregar uma noção de espaço. A partir de então, esse tipo de representação foi se distanciando da concepção de corte em projeção, e conseqüentemente, desenvolvendo-se em perspectiva.

Embora no final do século $\mathrm{XV}$, a perspectiva tenha se Figura 48 consolidado segundo regras precisas, Giuliano da Sangallo, ao representar o interior de Santa Sofia, desenhou-o com algumas distorções e sombras, assim como fazia Villard de Honnecourt, na Idade Média.

${ }^{5}$ Perspectiva matemática será denominada nesse estudo como a perspectiva baseada nas regras matemáticas, en contraposição com perspectiva realizad anteriormente, sob leis
O tratado de Filarete, sofrendo influências de Alberti, apresenta também a forma de representar um projeto de arquitetura. Para ele, uma vez desenhada a planta, e essa aceita pelo "cliente", era necessário construir uma maquete, que em suas palavras era "também um desenho em três dimensões" (LOTZ, 1985, p. 06). Apesar de somente apresentar como 
elementos fundamentais de representação, a planta e a maquete, o tratado de Filarete enuncia o que seria o primeiro desenho de interior em perspectiva, feito por um arquiteto renascentista - uma representação de um projeto imaginário "Casa das Virtudes" - "uma construção de muitos pisos, de planta circular, que se compõe de uma escada caracol central em forma de torre, rodeada por dois anéis concêntricos de loggias". (LOTZ, 1985 p.06). Filarete explica que as duas loggias somente poderiam ser vistas em seção: o poço, isto é, a escada caracol, "não poderia desenhar-se a menos que se fizesse com saliências, como deve ser, pois é necessário que a mente compreenda o modo e a forma que tem" (LOTZ, 1985, p.07). Essa observação esclarece até que ponto o desenho era um substituto insuficiente da maquete tridimensional. Esse tipo de perspectiva, presente no tratado de Filarete, não pode ser considerado como uma representação cientificamente correta dos edifícios, indispensáveis para o arquiteto, e nem ser visto como um desenho próprio de trabalho.

“As ilustrações de Filarete são aparentemente obra de um amador, mas em sua forma peculiar vão mais além das perspectivas de Pisanello e Jacopo Bellini, e também, (...) das de Alberti" (LOTZ, 1985, p.08). Ele representava o espaço partir de um ponto de vista não ao nível do solo, mas em um plano imaginário mais elevado, podendo ser comparado, inclusive, com a perspectiva cavaleira que será desenvolvida somente no último quarto do século XV.

Não se pode atribuir nenhuma data e nenhum arquiteto específico na criação da seção em perspectiva no Renascimento. Tanto Leonardo, quanto Francesco di Giorgio Martini e até Bramante usaram tal método de representação. Sabe-se apenas que surgiu entre os arquitetos da corte de Ludovico, o Mouro,

em Milão.

Nem os desenhos ideais de Leonardo, nem os esboços arquitetônicos de Francesco di Giorgio são desenhos de trabalho no mais estrito senso dos sentidos. Até final do século XV, os espaços interiores maiores e mais complexos se desenharam e visualizaram unicamente por meio de maquetes. Até 1500 aproximadamente não começam a aparecer indicações de sua substituição por desenhos de espaços interiores. (LOTZ, 1985, p. 09)

Um exemplo dessa mudança pode ser interpretado na coleção de desenhos de arquitetura, conhecido por Codex Córner, de Thomas Ashby, e atribuído ao círculo de Bramante, principalmente por evidenciar a própria forma com que Bramante criava seus espaços interiores. Por exemplo, Santa Maria presso San Satiro, em Milão, era um espaço para ser Figura 49 visto em perspectiva.

Esse volume inclui além do Panteão, desenhos de edifícios contemporâneos como o Tempietto de Bramante, apresentados em corte em perspectiva como vôo de pássaro, que consistia em elevar a linha de horizonte, e acabava privando o observador de captar o tamanho real do edifício.

Os primeiros desenhos em perspectiva "vôo de pássaro" apareceram na de Leonardo. Os desenhos de Leonardo apresentavam diferenças em relação aos do Codex Córner de Bramante. Enquanto o primeiro cortava o edifício e colocava o desenho em planta no solo para dar idéia de continuidade do edifício, no segundo havia uma linha de limite do solo, como se fosse um corte no edifício, onde tudo 


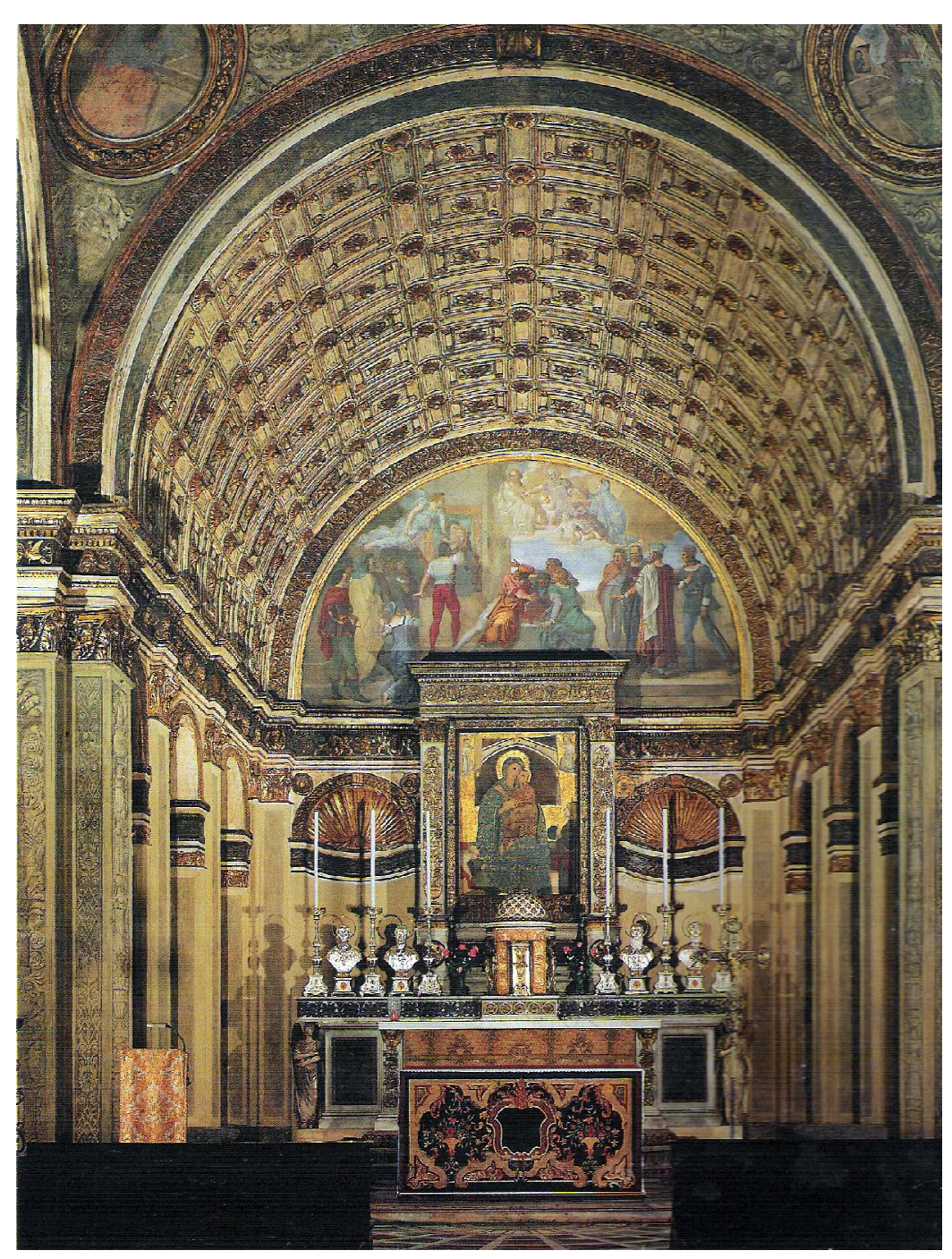

que existisse anterior a ela era desprezado. Com isso, Leonardo se esforçava para obter clareza em sua representação, e fazer essa abstração do edifício mais facilmente inteligível para o observador, ao passo que, o artista do Codex Córner não tinha nenhuma intenção de disfarçar o caráter ilusório da seção.

Já não estamos mais frente aos planos ininterruptos de princípios e meados do Quattrocento, como as que aparecem com clareza no desenho de Pisanello; a norma para compor um espaço já não constitui a ratio, isto é, os planos simples, e as figuras estereométricas que acabam. O espaço interior de Bramante está definido pelas reentrâncias e saliências da parede, pelas luzes e as sombras que criam, e pelo perfil tridimensional e o relevo do muro. Esta éa razão
Figura 49 - Bramante. Santa

Maria presso San Satiro.

(MILLON e LAMPUGNAN

1994, p.153)

pela qual encontramos o mesmo conceito de espaço, baseado na forma eno volume, no relevo em perspectiva do falso presbitério de Santa Maria e nos desenhos do Codex Córner. Em ambos casos o espaço está indicado por sua relação com o relevo da parede que rodeia. (LOTZ, 1985, p.12)

Os desenhos de arquitetura feitos por pintores eram tão freqüentes durante o Quattrocento (século XV), que quase foram considerados uma regra geral. Porém, para atividade de construção de um edifício era muito difícil seguir apenas os desenhos de um pintor.

Essas formas de representar o espaço em perspectiva influenciavam os arquitetos sobre o próprio jeito de conceber o espaço arquitetônico, como pode ser visto no Tempietto de Bramante. Uma construção sem escalas coerentes, mas com uma representação em perspectiva excepcionalmente perfeita. Um edifício para ser apreendido segundo o ponto de fuga, ou seja, a visão do observador.

A intima relação entre o método de representação usado no Codex Córner e os princípios de configuração inerentes aos espaços interiores de Bramante, provavelmente podem explicar com muita facilidade o feito de que o arquiteto, embora não tenha sido o verdadeiro criador da seção em vista de pássaro, criador da seçáo em vista de passaro, aperfeçoou-a uso-a sistematicamente (LOTZ 1985, p.15).

${ }^{6}$ Redução de uma figura segundo as regras da perspectiva. Figura reduzida m relação ao seu tamanho natural.
Segundo os renascentistas, para obter o 'escorço' ${ }^{\prime}$ era necessário interceptar com um "vidro" (um plano) a pirâmide visual constituída por raios que, seguindo trajetórias retilíneas, iam do objeto ao olho ou do olho ao objeto, resultando em 
um problema de geometria, o qual deveria ser resolvido para representar a correta proporção entre os elementos reais e os desenhados em perspectiva. Esse era o princípio básico para o desenvolvimento das teorias da perspectiva linear, ou com um ponto de fuga.

É importante ressaltar que a perspectiva no Renascimento trouxe a possibilidade de racionalizar o espaço, ou seja, criar um espaço ótico de dimensões mensuráveis, dispondo matematicamente os objetos tridimensionais em um plano bidimensional.

Os artistas do Renascimento descobriram que essa mesma lei rege a relação entre qualquer ponto do espaço e o olho de um observador e, conseqüentemente, o problema da racionalização do espaço coincidiu desde 0 primeiro momento com o problema de harmonização do espaço. (WITTKOWER, 1979, p. 543).

Para Panofsky (1979), a perspectiva matemática no Renascimento não servia apenas para garantir a correção visual, mas também como um instrumento que assegurasse a perfeição estética da obra.

As correções também eram interpretadas segundo proporções. Para Manetti, em sua biografia sobre Brunelleschi, esse grande arquiteto é que inventara a perspectiva para expressar proporcionalmente os objetos mais próximos, que apareciam maiores, e mais distantes do observador, que se revelavam menores. Esse aumento e diminuição estavam relacionados com a distância entre o observador e o objeto analisado. Piero della Francesca, em sua obra, De prospectiva pingendi, chama essa perspectiva de commensuratio, que significava a relação entre a distância que o objeto está do observador e sua dimensão aparente na seção transversal (plano de intersecção) da pirâmide visual.

Leon Battista Alberti, em seu livro dedicado à arte da pintura, De Pintura, descreve o que seria a pirâmide visual e coloca a pintura como um plano de intersecção na pirâmide visual entre o observador e o objeto observado. E, seguindo o teorema de Euclides de semelhança de triângulos, afirma que a proporção resultante da representação bidimensional com a observação do objeto poderia ser cientificamente embasada pela relação matemática, ou mesmo proporção, entre o triângulo formado pela pirâmide visual e o "outro" triângulo formado pelo cone visual do plano da pintura com o observador

Em outras palavras, Alberti discorre sobre o método de semelhança de triângulos de Euclides para garantir aos pintores que a perspectiva era fruto de uma relação matemática existente entre o objeto e o observador. A relação existente entre cada parte no objeto real deveria apresentar-se também no objeto representado, ainda que a dimensão fosse outra, deveria Figura 50 assim mesmo, ser proporcional.

O termo proporzionalità indicava no Renascimento, a relação entre proporções, assim como a proporção significava a relação entre razões. Esse termo apareceu no comentário feito por Daniele Bárbaro ao texto de Vitruvio, ao afirmar que o segredo da arte estava na proporcionalidade, o que poderia ser entendido como um sistema de proporções que regulasse 


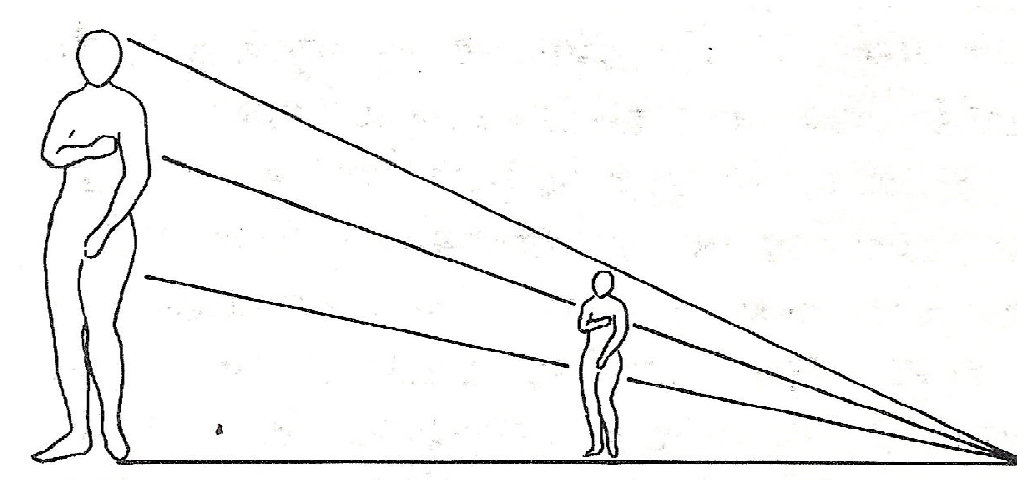

50 - Esquema da perspectiva a partir de ângulo visual. (WITTKOWER, 1979, p.545)

toda a arquitetura, ou mesmo, toda obra de arte.

Esse sistema poderia ser decodificado tanto em um sistema métrico, em números, quanto em geometria, pela semelhança de triângulos. De qualquer forma, em ambos os sistemas, deveria haver uma correspondência entre suas partes e delas com o todo para garantir essa proporcionalidade.

Alberti, em seu tratado De re aedificatoria, aconselha os arquitetos a trabalhar com desenhos e maquetes na concepção da obra. E, segue dizendo, que não deveriam fazer perspectivas sem medidas absolutas, isto porque, para ele, o arquiteto deveria conhecer, além de outras disciplinas, matemática e pintura, que o aproximaria das regras da perspectiva que estavam sendo desenvolvidas.

Piero Della Francesca, na sua obra De prospectiva pingendi, reformula a teoria de Euclides da semelhança de Figura 52 triângulos já estudada por Alberti, recorrendo a números para sua demonstração. O estudo de Piero preocupava-se também com a diminuição dos objetos no espaço, na representação em perspectiva.

A grande dúvida nesse momento era: a diminuição do objeto variava segundo a distância ou com a posição do observador?
Figura 51 - Santa Maria del Popolo, Roma, por Thiersch. (WITTKOWER, 1979, p.546)

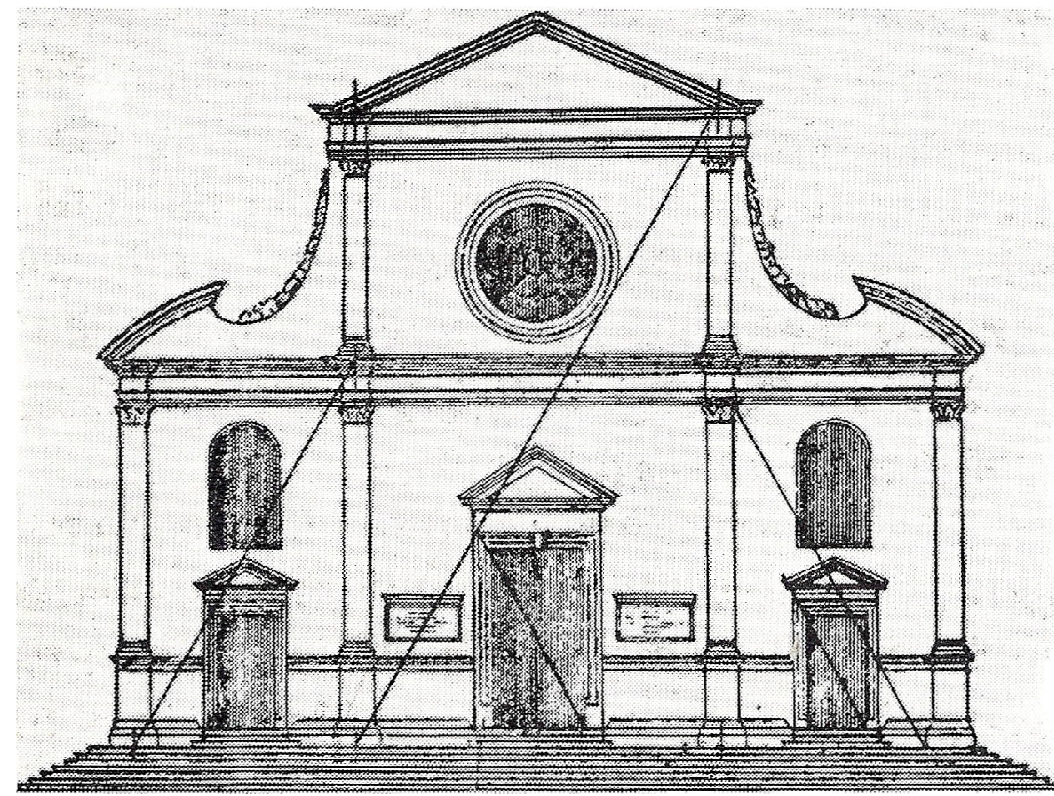

Os teóricos do Renascimento sabiam muito bem que a ótica clássica e medieval, baseada na medição do ângulo visual definido pelo olho e o objeto, não permitiria uma determinação matematicamente correta das razões entre a distância e a diminuição. (WITTKOWER, 1979, p.547)

ou seja, o objeto pequeno e próximo poderia ser visto sob o mesmo ângulo que um grande e distante. Para resolver esse problema, Piero definiu um elemento muito importante, a intersecção da pirâmide visual, que segundo ele, era o único artifício que possibilitava projetar os objetos observados em proporção e prever sua diminuição a partir de seu distanciamento. Com esses dados, procurou estabelecer uma única lei para essa relação.

Ao observar esse processo, resta uma segunda indagação: estaria contida nessa mesma lei a possibilidade de haver proporções entre as diversas projeções de diferentes objetos, na intersecção da pirâmide visual? Ou seja, ao retratar 


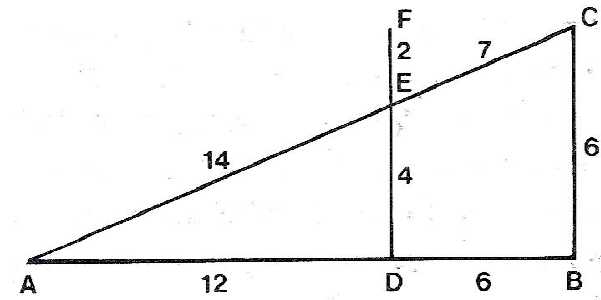

uma cena, os elementos guardariam alguma proporção entre si? Para isso, a premissa era que os objetos deveriam estar paralelos entre si e dispostos em iguais distâncias. Piero começa sua investigação dizendo que as projeções desses objetos não seguem nenhuma progressão, nem geométrica, nem qualquer outra. A partir de então, descreve a relação existente entre a projeção dos objetos sobre a intersecção e a distância entre o olho e a intersecção, deixando nítido que essa distância fazia diferença na diminuição aparente dos objetos. Nesse estudo, pode-se dizer que Piero usou novamente a semelhança de triângulos para formular essa "lei universal" das projeções, que nada mais é que uma proporção decrescente, onde a razão decrescente entre a altura dos objetos sobre a intersecção é inversamente proporcional à sua distância ao olho.

Leonardo, em notas datadas de 1490, relaciona as proporções em perspectiva com as consonâncias musicais, mostrando de maneira diferente, através de progressão aritmética, o que Piero havia demonstrado em suas progressões decrescentes. Leonardo determinou a razão entre cada projeção e a altura que cada objeto teria, considerando, porém, a distância do olho à intersecção em uma unidade e a distância da intersecção ao primeiro objeto em mais uma unidade, e desse ao segundo objeto mais uma unidade, e assim por diante; além de ter considerado a relação entre a altura do objeto, ou seja, no plano vertical.
Figura 52 - Esquema de SemeIhança de Triângulos. Estudos de Piero della Francesca. (WITTKOWER, 1979, p.547)
Piero, ao fazer sua progressão, já previa essas alterações e por isso, procurou por uma lei que fosse universal, independente da distância do olho à intersecção, e de sofrer diminuição vertical ou horizontal, como em um piso.

Está claro, portanto, que naquele momento concreto, o interesse de Leonardo se centrou em demonstrar o vigor das harmonias pitagóricoplatônicas no espaço ótico. No entanto, Piero parecia desejar a formulação de uma lei geral e infalível sobre as razões na perspectiva. (WITTKOWER, 1979, p.551)

Brunelleschi, cronologicamente analisando, deveria conhecer essas teorias da proporção na perspectiva, pois segundo Manetti, que escreveu sua biografia, Brunelleschi representava o tamanho dos objetos em relação com sua distância. Portanto, acredita-se que ele deva ter descoberto que as projeções dos objetos sobre a intersecção do cone visual são proporcionais a esses objetos, devido à semelhança de triângulos, principalmente, por se saber que esse arquiteto era grande conhecedor de matemática.

Não há indícios certos sobre Brunelleschi ter procurado explicar essas relações detalhadamente, como Piero e Leonardo, porém sabe-se que em seu círculo, os artistas deveriam ter conhecimento de tais técnicas também.

Pode-se afirmar claramente que "Brunelleschi havia descoberto que a projeção bidimensional era o único método para aplicar as leis das razões entre o olho do observador e a diminuição dos objetos no espaço" (WITTKOWER, 1979, p.551). 


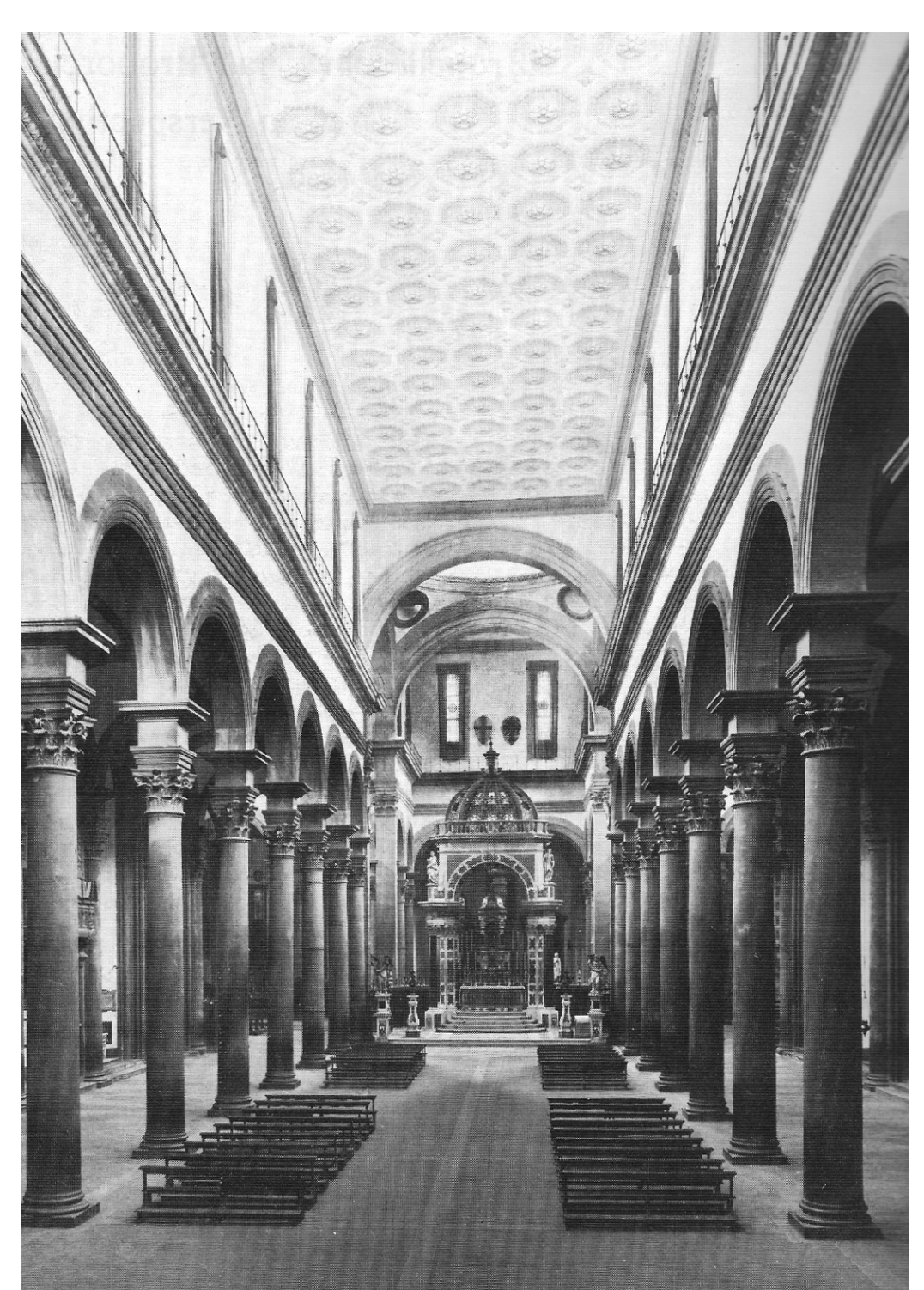

A arquitetura de Brunelleschi reflete esse pensamento sobre a proporção na perspectiva, através de uma homogeneidade de muros, espaço, luz e articulação. "Essas homogeneidades são as condições necessárias não só para garantir um desenvolvimento métrico coerente em planta e elevação, mas também para assegurar razões contínuas na perspectiva". (WITTKOWER, 1979, p.552).

Os interiores das igrejas de San Lorenzo e de Santo Figuras 53 e 54 Spirito indicam esse pensamento de Brunelleschi. A diferença de Brunelleschi em relação a Alberti e Piero della Francesca, quanto ao uso de perspectiva linear, baseia-se no fato de que o primeiro reconhecia que os teoremas matemáticos da
Figura 53 - Interior de Santo Spirito, Florença. Brunellesch (WITTKOWER, 1979, p.542).
Figura 54 - Interior de San Filippo Brunelleschi. (HEYDENREICH, 1996, p.16)

semelhança de triângulos garantiam a proporcionalidade em um edifício metricamente coerente, tanto em suas elevações, como em suas vistas perspécticas. Essa proporcionalidade total do edifício era, para ele, dependente do postulado de uma intersecção imaginária da pirâmide visual, o que descarta a hipótese de movimento na obra, ou seja, o espectador deveria apreender essa arquitetura como uma tela. Com a perspectiva linear, Brunelleschi reforçou a certeza renascentista de que o olho do observador aprenderia a ordem métrica e a harmonia em todo o espaço.

Além de apresentar uma relevante diferença entre a arquitetura antiga e a renascentista, esse pensamento, mais tarde, refletiu o desenvolvimento da pintura ilusionista e a súbita prosperidade da arte dos intarsiatori. 
"A pintura ilusionista do Renascimento constitui um caso inverso ao da arquitetura. A idéia de pintar a realidade como se fosse real não é menor que a de construir em três dimensões e perceber o resultado como se estivesse pintada". (WITTKOWER, 1979, p.555).

Pode-se dizer que a historia da construção da Basílica de São Pedro refletiu as diferentes formas de concepção de perspectivas interiores, podendo representar, inclusive, uma seqüência, ou uma "evolução". Desde aquelas feitas como no Codex Córner, do círculo de Bramante, assim como as de Peruzzi, com uma mistura de perspectiva com projeção ortogonal, e ainda as de Giuliano da Sangallo, com sua também perspectiva mista, onde alguns elementos se encontravam em perspectiva sobre uma base quase totalmente ortogonal, sem a presença do piso da catedral, tão claramente desenhado nas vistas em vôo de pássaro.

Após a morte de Bramante, Rafael ficou encarregado da construção da basílica de São Pedro. Alguns anos depois, Rafael descrevia para o papa Leone $X$, sua teoria sobre as projeções ortogonais na representação gráfica da antiga Roma. Nessa carta, como visto anteriormente, Rafael estabeleceu o método da representação dos desenhos arquitetônicos e insistia na apresentação de planta, elevação e corte, separados.

Voltando a olhar um momento as seções em perspectivas do Codex Córner pode-se notar que o método de Rafael para representar um edifício consiste em uma ruptura com a perspectiva central e seu conceito espacial subjacente que consiste em uma seção através da pirâmide ótica, tal como foi definido por Alberti e concretizado por Bramante em seu

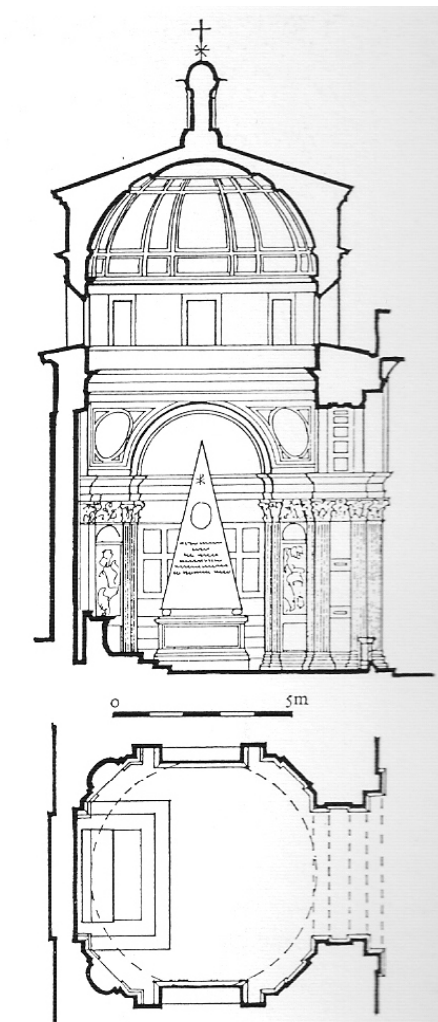

Figura 55 (acima) - Capela Chigi, S. Maria del Popolo, Roma, 1513. Corte e planta. Rafael. (LOTZ, 1998, p.28).

Figura 56 (direita) - Capela Chigi, S. Maria del Popolo, Roma, 1513. Rafael. (LOTZ 1998, p.28).$$
\text { seus }
$$
fechado.

Rafael separou as vistas das paredes de fora e de dentro. Essa separação refletiu também na concepção do espaço. Agora, o observador não conseguiria mais apreender o edifício de uma só vez, teria que percorrer o espaço. Como por

Figuras 55 e 56 exemplo, em sua obra da Capela Chigi, que se contrapunha ao falso presbitério de Bramante, onde os ornamentos das paredes eram considerados em primeiro plano, como algo que deveria prender a atenção do observador. Com Rafael, a necessidade de apreender o espaço como um todo, fez com 
que o ornamento ficasse em segundo plano, não menos importante, porém secundário em relação à impressão espacial.

As alterações na forma de representar a arquitetura não somente vieram dos ensinamentos de Alberti, como da necessidade de se apropriar de novas formas para apresentar o espaço da catedral de São Pedro, da qual Rafael se encarregou por seis anos.

Não se pode afirmar com certeza, porém, devido a casos isolados, pode-se crer que após a carta de Rafael em 1519, adotou-se a projeção ortogonal como instrumento de projeto, e também se alterou a forma de conceber o espaço. Agora não mais feito para uma perspectiva central, mas para um percurso no edifício, com várias vistas necessárias.

Antonio da Sangallo, assistente de Rafael, seguiu os passos do mestre e acabou desenvolvendo o tipo de desenho para arquitetos no sentido mais exato do termo. O método de projeções ortogonais representava para os pintores (ou arquitetos-pintores) uma forma estritamente profissional de arquitetura, e muito menos visual. Nesse momento, começou a ocorrer a separação entre os dois ofícios, que só se concretizou após 1530, aproximadamente.

Ainda assim,

Somente mesmo nos séculos XV e início do XVI, em uma época em que a perspectiva matemática era garantia não só de correção, mas inclusive de "satisfação estética", os métodos para desenhar um espaço interior poderiam se colocar como um problema artístico de tal magnitude, e com tal força para anunciar uma mudança no conceito de espaço.

E é sob esse panorama, no início da teorização das regras da arte e da arquitetura, que o modelo tridimensional mostra-se um instrumento de grande importância e eficácia no desenvolvimento e amadurecimento da idéia ${ }^{7}$ do arquiteto.

7 O termo Idéia teve um grande desenvolvimento evolução. O conceito adotado nesse texto segue o entendimento que Alberti azia desse termo: existência de um juízo ou idéia de beleza impressa no espírito do artista, que deveria ser contestada ou assegurada através da observação e estudo da natureza, do mundo exterior
A partir de estudos e documentos referentes ao período renascentista, acredita-se que tenham sido construídos centenas ou até milhares de modelos tridimensionais, porém somente poucos resistiram ao tempo, devido aos seus materiais e dimensões. A maioria dos existentes ainda hoje são modelos para igrejas do século XV e XVI, dentre os quais alguns se apresentam em grande escala. "Por várias vezes na construção das catedrais, tanto em Florença quanto em Bolonha, os modelos eram feitos de tijolos e eram tão grandes que se tornavam construções próprias."(GOLDTHWAITE, 1980 p.372) 
Não se pode afirmar que os renascentistas foram os primeiros a utilizar modelos tridimensionais na arquitetura, mas, ao que se tem notícia, foram os que os fizeram com maior riqueza em sua metodologia e regularidade. A maneira que os homens da Renascença seguiam para gerar uma obra arquitetônica era a mesma na execução de um modelo, sempre com rigor técnico e mantendo profundamente suas proporções, para não deixar que se escapasse a beleza idealizada pelo artista.

Ligado a um pensamento de regularização e racionalização da arquitetura e da profissão do arquiteto, o modelo também foi idealizado segundo o pensamento científico e rigoroso do Renascimento. À medida que a arquitetura passa a ser considerada arte liberal, e com isso, ter seus próprios fundamentos teóricos, a figura do arquiteto começa a ganhar nobreza, garantindo o respeito justo às suas criações, tanto no desenvolvimento de um projeto, quanto na qualidade de execução de uma obra.

A prova que se tem da presença de modelos na Antiguidade vem de escavações em antigos locais da Mesopotâmia, Egito, Roma e Grécia, onde foram descobertos alguns pequenos modelos de habitações e templos.

A civilização mesopotâmica tinha como característica o trabalho em barro. A argila, mesmo queimada, não é capaz de suportar choques, portanto, foram poucos os indícios de modelos que chegaram até hoje. Um exemplo da presença de Figura 57 modelos é a "casa redonda", proveniente de Mari, e registrado 


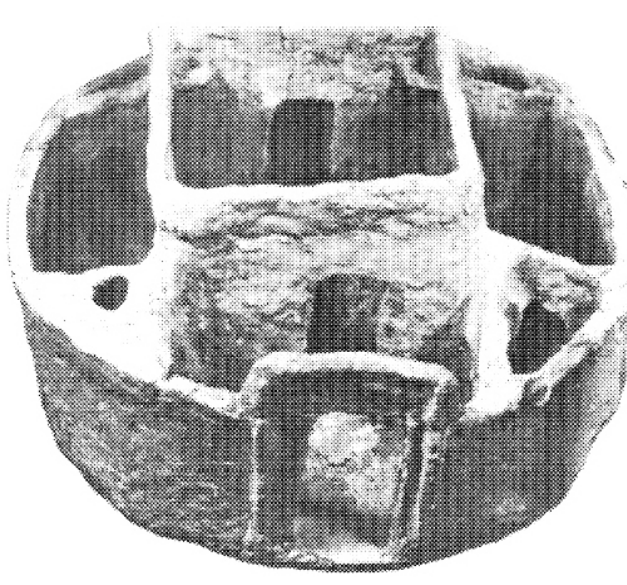

como uma grande raridade. Outras peças, também de habitações, foram encontradas no templo de Istar, em Assur. Embora seja comprovada a existência desses modelos na Mesopotâmia, não é possível afirmar seu uso próprio para a execução da arquitetura. Baseado nas características dessa civilização, alguns historiadores (como Hamann) apenas confirmam o caráter simbólico-religioso empregado a essas peças.

No Egito, a presença de modelos é abundante. Em cada túmulo encontrado, entre outros objetos funerários, havia um modelo de habitação, que segundo a arqueologia, eram conhecidas como "casas da alma". Além desses, outros modelos também foram encontrados nas escavações do Egito, que se acreditava ter uma finalidade recreativa ou de adorno, pois eram peças em pedra, madeira ou marfim, como miniaturas de casas e torres.

Se, por um lado, entre os modelos que abundam com diversas finalidades, não podemos apontar quais os que poderiam ter servido como apoio na criação da arquitetura, por outro, pode-se presumir que não havia motivo para que não fossem, conhecendo o custo elevado do papiro
Figura 57 - Modelo de cas encontrado em Mari. (OLIVEIRA, 2002, p.188)

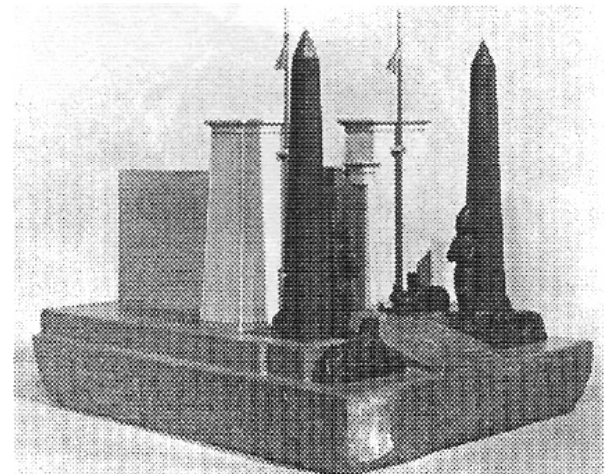

Figura 58 - (acima) Reconstituíção de maquete de um templo. (OLIVEIRA, 2002, p.191).

Figura 59 (direita) - Maquete de jardim de um nobre. (OLIVEIRA, 2002, p.191).

O modelo de um pequeno templo egípcio, exposto atualmente no Museu do Brooklyn, embora reconstruído

Figura 58 recentemente, ainda guarda as informações que estavam presentes no original. Essas informações referem-se a detalhes da construção que representa, como por exemplo, a descrição de que a porta tinha sido revestida de cobre.

Outro modelo também interessante desse mesmo Figura 59 período representa um jardim nobre, que embora se apresenta atualmente sem a suposta vegetação (provavelmente de material mais perecível que a base de pedra), ainda mantém os pequenos orifícios onde estavam "plantadas". Além disso, podem ser vistas algumas depressões escavadas na pedra, que muito provavelmente representavam lagos - elemento paisagístico bem em voga na época.

Os modelos mais antigos eram feitos em argila cozida, como era o caso das casas da alma, do Antigo e Médio Império. A partir do Novo Império, novos materiais foram incluídos: como madeira, pintada ou natural, marfim, pedra (calcáreo) e em alguns casos, metal. 
Na Grécia e em Roma, não se pode afirmar o uso de modelos para a construção. Vitruvio, em seu texto, não expressou nenhuma evidência concreta sobre as regras dessa atividade. Porém, mesmo não tratando de modelos diretamente, indiretamente, Vitruvio contou uma passagem que levantou dúvidas sobre a existência de modelos na profissão do arquiteto. Segundo ele, "o arquiteto Callias quase desbanca, na cidade de Rhodes, o prestígio de Diognetus, o arquiteto oficial, mediante a apresentação de uma maquete que mostrava uma fortificação e máquinas de guerra para a defesa da cidade". (OLIVEIRA, 2002, p.117). A dúvida em relação a essa passagem refere-se às diferentes interpretações que o texto de Vitruvio sofreu ao longo dos séculos. Em algumas traduções o termo usado por Vitruvio foi traduzido como desenho e em outros como modelo.

No entanto, há outros textos que provam o exercício da modelagem na construção, como é o caso das especificações de Philon de Eleusis para o Arsenal do Pireu:

\begin{abstract}
(...) (347-346 a.C.) Tudo isto deverá ser executado por aqueles que forem contratados de acordo com as especificaç̃os e as medidas e o modelo, como recomenda o arquiteto, e deverão fazer a entrega nos prazos previstos em contrato para cada tarefa. (OLIVEIRA, 2002, p.92).
\end{abstract}

Em outro texto, de Delos, há a descrição de um modelo feito em madeira de palmeira, ou seja, madeira balsa, um flexível material, porém frágil e de pouca durabilidade.
Figura 60 - Modelo romano em pedra. (OLIVEIRA, 2002, p.208).

Esses antigos textos se referiam a maquetes não apenas da volumetria de edifícios, mas também de detalhes de fundação até de cobertura, ou mesmo de ornamentação.

Enquanto tem-se somente literaturas que apontam a possibilidade do uso de maquetes na construção, os modelos

Figura 60 de característica votiva são numerosos, tanto na Itália, como na Grécia, reforçando o costume de modelagem exercido pela civilização greco-romana.

Ainda como forma de representação de arquitetura, não pareciam modelos para a realização de alguma construção, como evidencia William MacDonald sobre o uso dos modelos feitos pelos romanos:

Existiam alguns modelos arquitetônicos embora não fossem feitos para serem mostrados a algum cliente, mas para serem colocados nas tumbas de arquitetos, ou na 
tumba de quem tivesse encomendado um templo ou alguma outra construção; esses modelos parecem ser grandes evidências de modelagem na época." (MacDONALD, 1977, p.31).

Na Grécia, segundo Spiro Kostof, não há dúvida que modelos de cera, ao menos para detalhes, eram certamente praticados no século $\mathrm{V}$ a.C., e com isso, também era inevitável a presença de alguns desenhos. Porém, concretamente, pouco se sabe desses modelos na Grécia: “A conta de Erechtheion mostra pagamentos para o (...) entalhador Neseu, que fez um modelo para as rosáceas do teto." (KOSTOF, 1977, p.15).

O uso de plantas como anotações de desenhos arquitetônicos na Antiguidade também acabaram recebendo a mesma função de seus pequenos modelos. Talvez o desenho, de Ghorab (citado no capítulo 01), por sua enorme precisão, Figuras 07 e 08 tenha sido a mais antiga evidência do uso de desenhos no "projeto" de arquitetura

Na Idade Média também há poucas indicações que evidenciam a existência e o uso de modelos arquitetônicos, sendo mais abundantes, principalmente na Itália, quase no final do período, ou seja, século XIII (transição para o Renascimento).

Assim como na Grécia e Roma, a quantidade de desenhos que fazem referência ao modelo na Idade Média é imensa, porém a iconografia deles não é tão vasta assim. Dos poucos sobreviventes restaram: a pedra tumular de Huges Libergier, o qual não apenas serve como epígrafo para

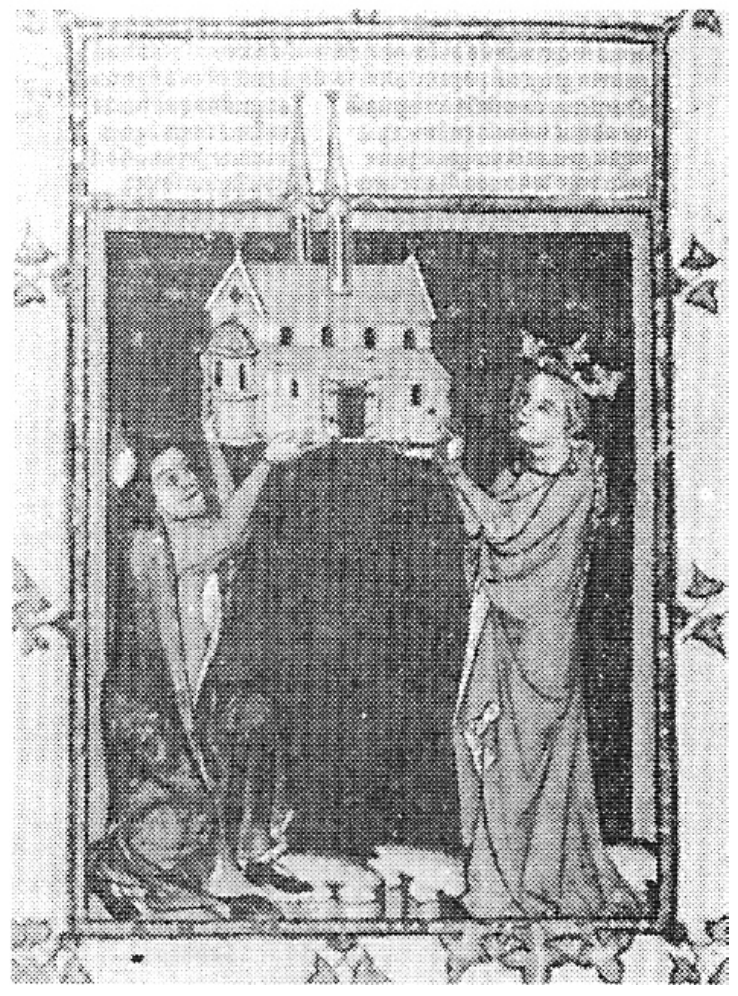

Figura 61 (direita) - Retrato do arquiteto Hugh Libergier, 1267. (KOSTOF, 1977, p.78)

(...) demonstrar a dignidade e a importância do arquiteto de então (século XIII), como também esclarece alguns processos usados pelo profissional de arquitetura. Libergier segura na mão direita uma pequena maquete, na esquerda a "virga geométrica" e a seus pés estão o compasso e o esquadro. Evidentemente, a maquete está entre os seus instrumentos de trabalho. (OLIVEIRA, 2002, p.168).

Figura 62

A ausência de modelos conservados da Idade Média pode ser justificada pelo uso de materiais frágeis como gesso e cera, e a execução de objetos de grande dimensões que eram demolidos após sua utilização na construção, uma vez que não havia nenhuma preocupação museológica para sua manutenção (que será apenas considerada na Idade do 
Humanismo).

Segundo Robert Branner, na Idade Média houve um abandono por parte de seus arquitetos à dependência do desenho na execução de um projeto. Grandes estudiosos como Branner, Harvey, Bucher, afirmam que os desenhos só eram apresentados em ocasiões especiais, devido ao alto custo para sua execução. Portanto, os métodos utilizados na Idade Média eram práticos e diretos, diferentemente da Antiguidade que, relatado por Vitrúvio em seu tratado De Architectura, seguia as três convenções gráficas de representação clássica, a saber: iconographia (plano, planta), orthographia (elevação) e scaenographia (perspectiva, mas não como a conhecemos atualmente).

Na Idade Média o arquiteto volta-se apenas para si próprio e sua experiência para servir de condução à realização da obra. Um esquema é concebido pelo arquiteto, e esse vai ao lugar e o projeta no solo, em escala natural. Dessa forma, o uso do modelo também se torna incerto nesse momento:

(...) a evidência de modelos arquitetônicos é ambígua. O modelo da igreja de St. Maclou em Rouen é o único exemplo que há no período medieval (...). Mas o modelo de St. Maclou parece representar um estágio posterior à construção da igreja e não anterior; isto é, não foi usado como um auxílio no processo de projeto, mas como um memorial subseqüente.(KOSTOF, 1977, p.74).

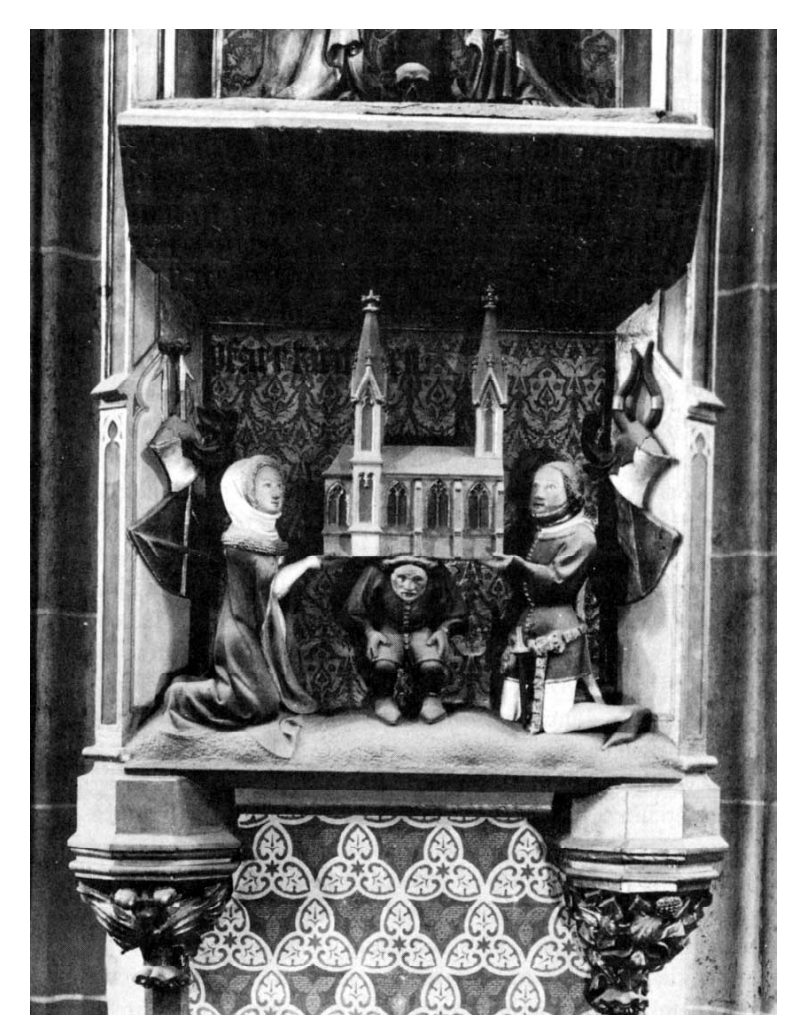

Apenas no século XIII, fim da Idade Média é que se volta a ter as instâncias de representação da arquitetura conhecidas até hoje, e que foram teorizadas e regularizadas no período seguinte, o Renascimento. “O uso de modelos e desenhos como função adicional na comunicação das idéias dos arquitetos a seus auxiliares marcou um avanço sobre o uso de modelos naturais em madeira ou gesso, tradicionais à Figura 63̧rática medieval." (GOLDTHWAITE, 1980, p.376).

Ohistoriador Goldthwaite afirma que no Renascimento a prática do modelo arquitetônico era muito habitual por fazer parte do desenvolvimento natural na concepção de arquitetura. Em alguns estudos, como os de Saalman, Lorenzoni, PaatzPaatz, entre outros, relata-se que na Itália do século XIV foram realizados inúmeros modelos para as catedrais de Milão, Firenze e Bologna, e ainda para edifícios de menor porte. "A palavra 'modelo' ocorre constantemente em documentos adjuntos à construção de catedrais durante o século XIV e à construção de cúpulas no século seguinte." 
(ETTLINGER, 1977, p.108).

Destaca-se também a herança de inúmeros desenhos provenientes de supostos canteiros de obra e que em boa parte tiveram que ser reproduzidos, comprovando mais uma vez, a coexistência de desenhos e modelos na representação de arquitetura no Renascimento.

Além de estabelecer uma fundamentação teórica sobre a essência intelectual do arquiteto, enquanto profissional, os tratados de arquitetura renascentistas também se pautavam sobre como deveria ser concebido e representado o produto de arquitetura, ou seja, o projeto. Em muitos desses textos, encontram-se teorias sobre a necessidade de representações gráficas pertinentes à atividade arquitetônica, além da inclusão de um objeto importante em seu estudo e comunicação: o modelo tridimensional.

Se anteriormente ao Renascimento há indícios de modelos tridimensionais para representar a arquitetura, podese dizer que, é apenas nesse instante que essa atividade passa a receber uma maior significação e importância na concepção da arquitetura e não só em sua representação.

No tratado De Re Aedificatoria de Leon Battista Alberti é possível verificar a importância e o incentivo à prática do modelo tridimensional: de modelos feitos de madeira ou de outros materiais, (...). (ALBERTI, 1989, Livro II, p. 96).

Alberti mostrava-se a favor de modelos sem seus elementos decorativos, visto que esses eram capazes de mostrar claramente a simplicidade das partes da obra, o real motivo do arquiteto, e não a riqueza de representação pertinente ao modelo. No Livro II, capitulo 1 do tratado, Alberti esclarece as potencialidades no uso de modelos, mostrando como na prática do projeto eram claramente observados os elementos teóricos explicitados no Livro I:

O uso de tais modelos permite olhar de modo claro, a disposição ordenada de todos aqueles elementos que descrevemos no Livro anterior: a posição em relação ao ambiente, a a delimitação da área, o número das partes do edifício e as suas disposições, a conformação das paredes, a solidez da cobertura, etc.,

e segue mais adiante, sugerindo, o que para ele faz parte da execução do projeto, a programação geral da obra nos seus vários aspectos, inclusive para determinar, além de sua

Além disso, poderá ser calculada a quantia necessária a ser gasta na construção - coisa muito importante - considerando, em todas qualidade, a quantidade dos materiais necessários à execução. me canso de recomendar o que deve fazer para compreender sua complexidade e as medidas das suas partes singulares, servindose não só de desenhos e esboços, mas também 
Alberti ressalta ainda o valor do modelo como uma forma de averiguar um desenho $\left(\right.$ disegno $\left.^{1}\right)$, fruto de uma idéia $\quad{ }^{1}$ Aqui se abre um parêntese pré-estabelecida pelo arquiteto. Essa idéia, ainda sem a sua $\begin{gathered}\text { para considerar que para } \\ \text { Alberti, disegno, que acaba }\end{gathered}$ exteriorização, era considerada por ele, imperfeita, e assim, só $\quad \begin{aligned} & \text { sendo traduzido por desenho, } \\ & \text { tem uma significação muito }\end{aligned}$ teria validade se fosse estudada através do desenho, com o maior (que esse termo en

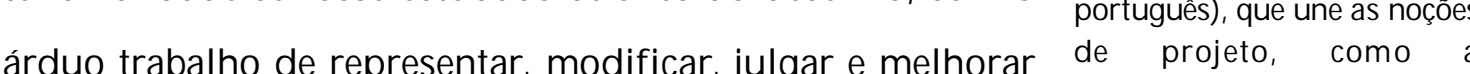
materialização de uma idéia sua intenção. O modelo, também componente desse trabalho, de representação gráfica deveria ser realizado parte por parte para garantir as apresentar essa idéia proporções de cada uma e de sua relação com o todo, primeira. Com isso, pode-se procurando sempre a harmonia do conjunto. dos séculos uma limitada apreensão dos termos, o que levou a um maior estudo da representação gráfica enquanto desenho do que importância do modelo como objeto também de formação de um projeto arquitetônico Talvez, por isso, não se tenha facilidade em encontrar literatura específica sobre modelos e nem os próprios, resgatados e recuperados $n$ atualidade.

Ao que me cabe, devo dizer que muito freqüentemente concebi obras que em um primeiro olhar pareciam louváveis, no entanto, uma vez desenhadas, revelavam erros, e gravíssimos, próprios daquelas partes que mais me davam prazer; e depois voltando a pensar sobre o que tinha desenhado, e corrigindo suas proporções, reconhecia e lastimava o meu p.36 descuido; enfim, após fabricar os modelos, ainda, examinando separadamente os elementos, ocorria de me enganar também sobre
"The problem of interpretation derives in part from the meaning of disegno as both a drawing and a general design idea that can be represented in either two or three dimensions, and in part from the meaning of modello as something that incorporates a design idea be it a model or a drawing". p.369). criação da obra de arquitetura, um meio de chegar a mais bela solução para um devido programa arquitetônico. Era uma matéria que deveria sofrer acréscimos, diminuições, mudança de proporções, antes de ser apresentada como um produto final para a apresentação da obra. Enquanto o arquiteto construía o modelo, ele poderia se certificar do que estava propondo, aclarando as idéias e reforçando cada parte proposta, sempre visando à perfeição de sua obra como um todo.

Assim como Alberti, vários outros artistas do Renascimento escreveram seus tratados. Era uma forma de estudar suas fontes, construir sua teoria, relatar seus próprios projetos e registrar sua produção. Entre eles, há os que também se referiram ao uso do modelo.

Antonio Averlino, conhecido como Filarete, discorre sobre a construção de modelos em seu tratado Trattato di Architettura, escrito entre 1460-1465. Neste, documenta o uso de modelos para aprovação de projeto e explicita a necessidade de modelos (e desenhos) em escala, construídos através de malhas reticulares de várias dimensões.

Em uma passagem do Livro VII, Filarete descreve a construção de um modelo em madeira de uma fundação, feito na mesma escala do desenho, que sobreposta e esse último, confirmava a relação direta entre o uso de desenho e de modelo na avaliação de uma idéia (MILLON e LAMPUGNANI, 1994, 
p.32)

Francesco di Giorgio (1439-1501), inicialmente pintor e escultor em Siena, também relatou seus feitos em um tratado. Desse tratado há muitas versões, todas muito bem ilustradas. Apesar de se ter documentado que Francesco di Giorgio fez alguns modelos para edifícios, como por exemplo, para Santa Maria Del Calcinaio (1450), Giorgio não discursa sobre modelos arquitetônicos em seu tratado, apenas sobre desenhos.

Mais precisamente na Itália, norte e centro, ao final do período Quattrocento (século XV), e início do Cinquecento (século $\mathrm{XVI}$ ), foram muito procurados documentos atestando o pagamento a arquitetos, carpinteiros, torneiros e entalhadores para registrar as atividades desses, na construção da obra e também de modelos. Há registros de pagamento feitos a carpinteiros e entalhadores para os modelos da torre da galeria transversal do Duomo de Milão, feitos a partir de desenhos de Francesco di Giorgio, Bramante (1444-1514), Leonardo (14521519), entre outros. Outros documentos como esse também afirmam a construção de modelos para a catedral de Pavia e Bologna, para Santa Maria delle Carceri em Prado, obra de Giuliano da Sangallo, para a fachada de San Lorenzo em Firenze, para Santa Maria di Loreto e para a Santa Casa, ambos de Bramante, para Santa Maria della Consolazione em Todi e para San Biagio em Montepulciano de Antonio da Sangallo, o Velho (MILLON e LAMPUGNANI, 1994).

O modelo tridimensional foi assumindo novas perspectivas no decorrer do Renascimento. Tornou-se um objeto representativo da materialização de uma idéia já consolidada pelo artista e que deveria ser expressa para apresentar a obra a quem o tivesse encomendado. E ainda, poderia funcionar como guia para os mestres e artesãos que iriam construí-la. E nesse contexto, os modelos parciais encontram seu lugar, como representações de algum detalhe para uso no canteiro.

Os modelos tridimensionais do Renascimento podem ser divididos em algumas categorias, reconhecidas atualmente, e catalogadas segundo sua funcionalidade, tanto na concepção, quanto na execução de uma obra. Pode-se dizer que, no Renascimento, o uso mais comum do modelo era para a apresentação e, conseqüentemente, aprovação ou alteração de projeto. “Modelos - assim como desenhos - eram preparados em um primeiro momento para a aprovação do patrão, embora raramente fossem seguidos." (ETTLINGER, 1977, p.109).

No entanto, alguns documentos ou mesmo exemplares de modelos mostram diferentes visões em relação à finalidade do uso de modelos. Alberti incentivava o uso do modelo por todos que quisessem estudar um projeto, Filarete acreditava ser usual o uso de modelos para a apresentação do projeto a quem o encomendou.

Além dessas duas principais categorias: modelos para estudo de projetos, modelos para aprovação de projeto; há ainda os modelos para concursos, que eram numerosos no Renascimento; os modelos chamados de definitivos, que eram aqueles que serviriam de guia durante a construção do edifício; e os modelos de detalhes ou particularidades da obra, que, também numerosos nesse período, constituíam os modelos em escala e os moldes em tamanho natural, feitos de madeira, argila ou pedra. 
Nessa última categoria foram acrescidos também os modelos específicos que reproduziam uma parte existente do edifício, como um capitel ou uma cornija, os quais poderiam depois, mantendo a dimensão original ou modificando-a, serem adaptados ou reproduzidos em um novo projeto.

Fillipo Brunelleschi (1377-1446), grande arquiteto do início do Renascimento e um dos pais da perspectiva (outro importante instrumento na representação de arquitetura), também confiava na prática de modelos para a arquitetura.

Ao desenhar o projeto para a igreja de Santo Spirito, Brunelleschi apenas entregou um desenho em planta, ou melhor, das fundações, sem levar nenhum outro instrumento. Em sua apresentação do projeto, somente contou verbalmente o que pretendia. Porém, após a discussão e decisão final do projeto, Brunelleschi recebeu o "encargo para fazer ou mandar fazer, uma maquete de madeira em pequena escala". (LOTZ, 1985, p. 04).

Em 1419, Brunelleschi e outro arquiteto do período, Lorenzo Ghiberti (1378-1455), prepararam alguns modelos para o concurso da construção do complemento do tambor e da cúpula do Duomo de Firenze (Catedral de Florença - Santa Maria dei Fiori). O modelo vencedor veio substituir um outro, de 1367, construído em tijolos, que representava o projeto da cúpula, feito pelos mestres-artesãos responsáveis pela construção da catedral.

Durante a construção da catedral Santa Maria Del Fiori, surgiram algumas dificuldades técnicas na execução da cúpula, resultando na paralisação da obra até Brunelleschi propor um novo projeto através de seu modelo, no concurso de 1418. O
Figura 64 - De Giorgio Vasari. Brunelleschi apresentando o modelo para Cósimo de' Médici. (KOSTOF, 1977, p.110).

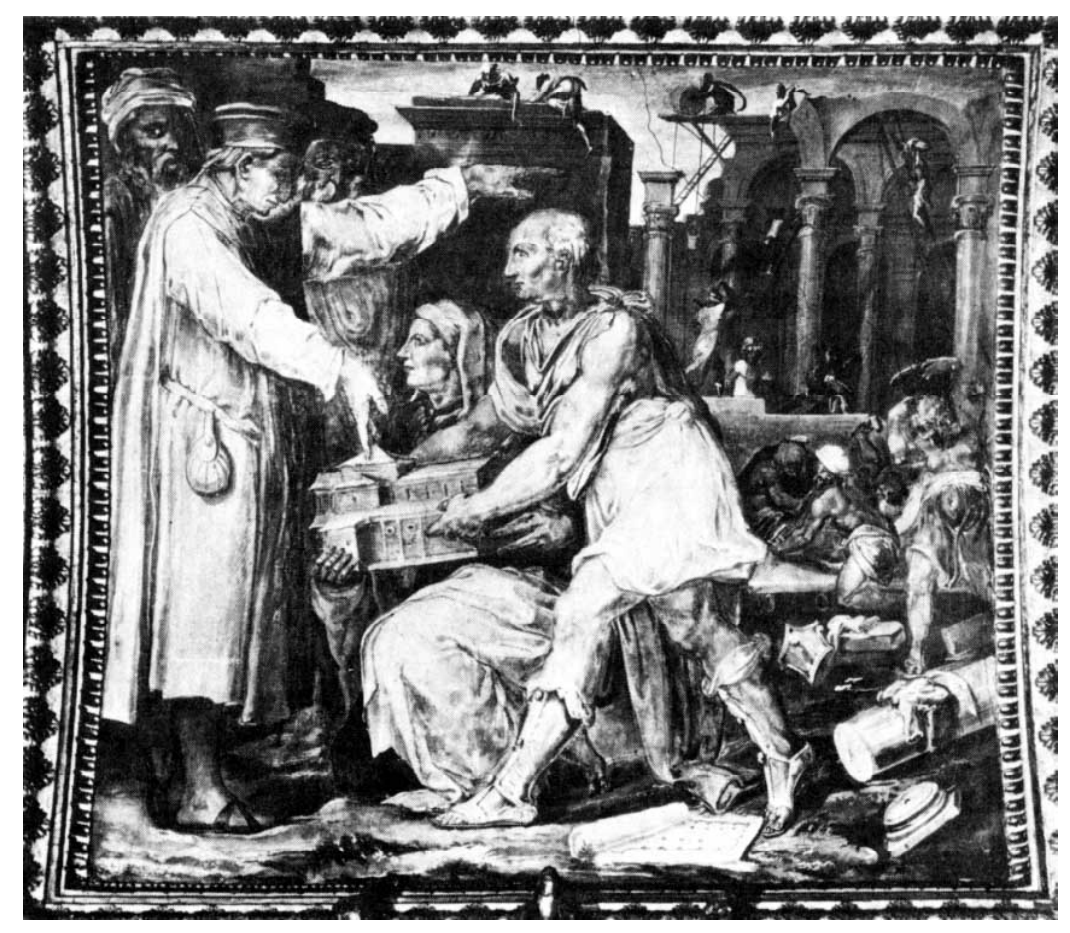

historiador Leopold Ettlinger, conta que para a solução de sua cúpula ser seguida, Brunelleschi fez diversos modelos, mostrando-a passo a passo.

O modelo de Brunelleschi era feito em madeira e tijolos e ele pretendia construir a cúpula sem nenhuma armação. Para isso, recorreu a desenhos e pequenos modelos parciais, esculpidos em argila, cera, madeira, e outros materiais usados na época.

Em 1436 a cúpula foi completada, e em um novo concurso, Brunelleschi e Ghiberti fizeram um projeto e modelo para o lanternim que iria completá-la.

Há outros documentos que confirmam também a existência de modelos realizados por Brunelleschi para "Santa Maria degli Angeli, per la Cappella dei Pazzi a Santa Croce (...), per San Lorenzo e Palazzo Medici" (MILLON; LAMPUGNANI, pp.22, 1994), no qual esse último foi recusado por Cosimo de' Médici, segundo afirmações de Vasari, que também relata pedidos de modelos para fortes em Vico, Pisano, Pisa e Pesaro, 
feitos pelo próprio Brunelleschi.

Em algumas obras menores, conta Manetti, que Brunelleschi não realizava modelos. No máximo um desenho para explicar aos construtores, embora esse não fosse o procedimento mais usual, já que em muitos casos houve erros de interpretação por parte dos construtores, sem a presença do arquiteto na obra ou de algum modelo como base. O pórtico para o Ospedale degli Innocenti foi para o canteiro como um desenho em pequena escala, com indicação de medidas.

A Basílica de São Pedro em Roma traz uma história inteira de modelos arquitetônicos durante sua construção, através dos séculos. Modelos feitos por Bramante; Rafael (14381520); Peruzzi (1481-1536); Antonio da Sangallo , o Jovem (14841546), que fez dois modelos, no qual um é completo e existente até hoje; Michelangelo, que fez quatro modelos principais, no qual o quarto teve uma modificação feita por Della Porta (15321602) e existe também até hoje; e Della Porta.

O Modelo de Michelangelo para a cúpula da Basílica de São Pedro gerou muita discussão sobre seu projeto final para a igreja. Embora tenha sido conservado até os dias de hoje, esse modelo foi reaproveitado por Della Porta, que lhe inclui seu novo projeto para a cúpula. Essas alterações tornaram-se fruto de grande investigação para tentar diferenciar o que seria de autoria de Michelangelo e de Della Porta. Essa discussão aparece nesse estudo no capítulo a seguir.

Michelangelo também utilizou modelos tridimensionais em outros projetos. Como, por exemplo, para a Fachada de San Lorenzo, em Florença - modelo mencionado em uma carta do artista a Domenico Buoninsegna, em 2 de

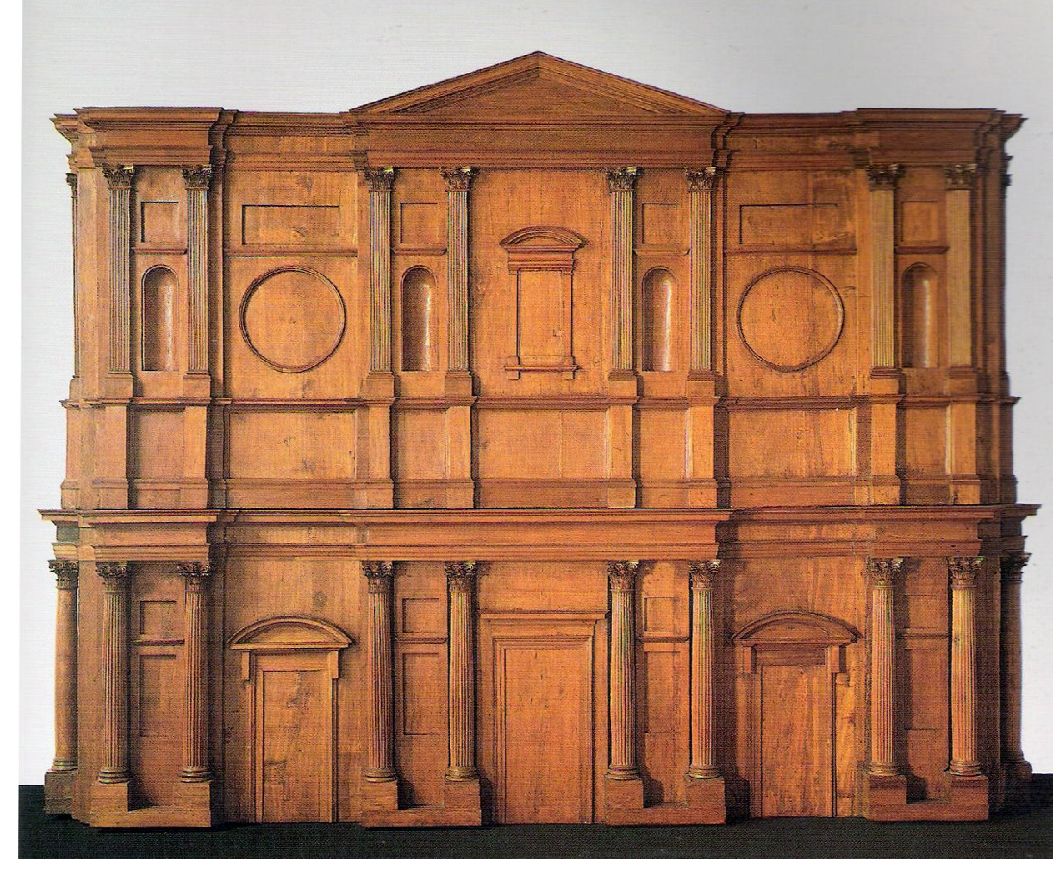

maio de 1517; para a escadaria de entrada à sala de leitura da Biblioteca Laurenziana - relatado também em carta, em 16 de dezembro de 1558, a seu sobrinho Leonardo; e para San Giovanni dei Fiorentini, em Roma.

A história de Michelangelo e seus desenhos para a Figuras 65 e 66 fachada da igreja de San Lorenzo tornaram-se quase incompreensíveis, devido ao grande envolvimento de arquitetos e inúmeras mudanças feitas no programa, dentro de um curto espaço de tempo. Michelangelo ganhou a comissão e dedicou, aproximadamente, dois anos supervisionando a pedreira de blocos de mármore, mas, no fim, Clemente VII anulou seu contrato e o projeto praticamente desapareceu.

Dessa história conhece-se apenas algumas informações sobre seus modelos que sobreviveram ao longo do tempo. O esplêndido modelo em madeira para a fachada de San Lorenzo é o maior dentre os definitivos, oriundos de uma série de 


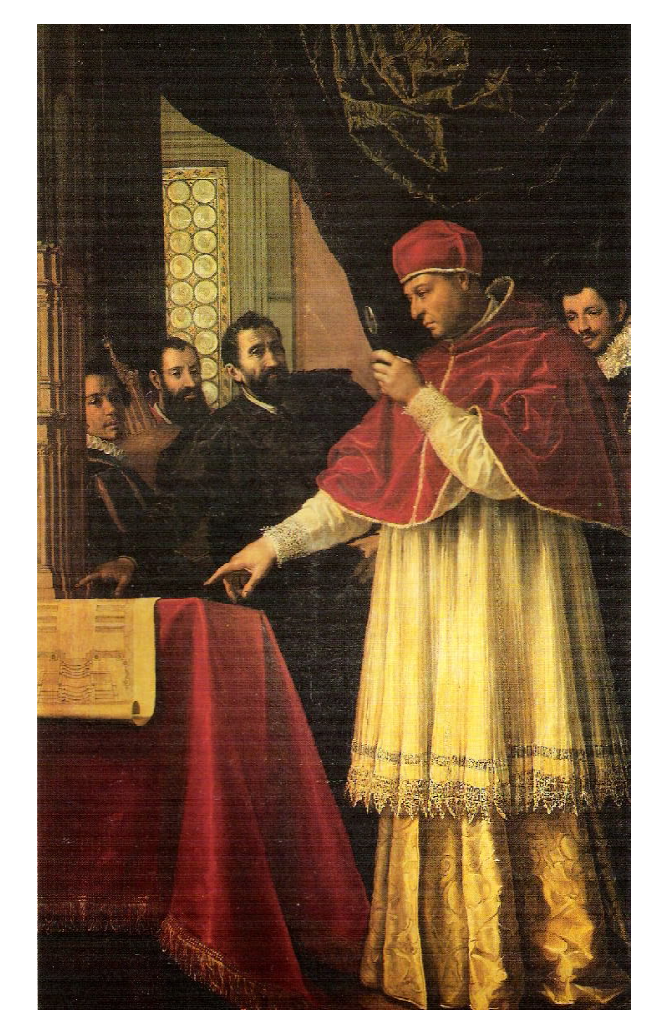

modelos preliminares, um dos quais de argila.
Figura 66 - Michelangelo apresent a ao papa Leone $X_{0}$ modelo para a fachada de San Lorenzo. (MILLON e LAMPUGANI, 1996, p.46).

O menor dos dois modelos finais, desaparecidos, mas documentados por Giovan Battista Nelli, no século XVII, quando ainda apresentavam decoração escultórica (MILLON, 1988, p.64), talvez tivesse sido construído para a apresentação a Leone X, a fim de garantir a aprovação do pontífice. O modelo maior, ainda existente, possuía uma outra função, a de servir de guia para a construção.

O uso de modelos no Renascimento, pouco a pouco, tornou-se mais intenso com os concursos que eram lançados. A forma de comparação e avaliação era sempre feita através de modelos, permitindo aos avaliadores apreender o projeto final.

Os modelos de concurso muitas vezes serviam também para guiar as construções. “Uma vez escolhido o vencedor do concurso, o modelo tornava-se uma garantia do produto final, assegurando que o patrão tivesse entendido as intenções do

arquiteto e tornando o arquiteto o responsável pela execução da obra." (GOLDTHWAITE, 1980, p.373).

Nos anos seguintes, surgiu uma nova prática, a revisão de modelos já construídos, como forma de estudar alguma obra anterior, ou para a colocação de um elemento novo, posterior à execução da obra, ou até para a complementação de algum projeto ainda em execução.

Observando os exemplos dos modelos de Brunelleschi e Michelangelo, pode-se perceber que houve uma passagem a um nível mais alto de habilidade executiva. A inclusão de elementos escultóricos e a tentativa de simular materiais a serem utilizados em obra, mostram esse refinamento que começa a aparecer nos modelos do século XVI.

Os modelos do século XIV e XV eram realizados sob um outro conceito, com menor inclusão de detalhes de ornamentação e sem incluir cor para representar os materiais. Para Brunelleschi, construir o modelo de forma mais "simples" significava manter o controle sobre a obra, assim também para Alberti, o qual afirmava que os elementos escultóricos poderiam chamar mais a atenção do que a verdade da obra. Para ambos, os modelos deveriam ser "simplificados", evidenciando somente a disposição dos elementos principais. A beleza da obra deveria vir da estrutura da imagem, a qual deveria estar em equilíbrio através de concordância (harmonia) entre suas partes e entre essas com o todo. E é essa beleza primeira que deve ser alcançada no modelo, não sendo necessária a colocação de seus ornamentos. 
da aparência da obra e da escala da construção, e pareciam carecer de detalhes. Estes, e muitos outros, foram causa de discussões entre os desenhistas e os responsáveis pela execução dos projetos. É bastante claro que Brunelleschi e outros eram invariavelmente esperados para dar instruções constantemente nos canteiros de obra. (ETTLINGER, 1977, p.109).

Ao contrário desse pensamento, os modelos mais correntes no século XVI se caracterizavam pelas relações entre as mínimas particularidades de ornamento e a apresentação do conjunto final, procurando sempre atentar aos detalhes do todo e das pequenas partes compositivas. Nesse momento houve uma predileção por se fazer modelos completos, a fim de garantir o menor risco de falta de definição e de alteração durante a construção do edifício. Por serem completos, também era possível a interferência de quem encomendou antes mesmo do início da obra, tanto no conjunto, quanto em suas particularidades.

No final do século XVI, a prática comum do uso de modelos na concepção e execução de uma obra começou a mudar, ainda que a utilização dos modelos de particularidades e reprodução de edifícios existentes (levantamento, estudos) tivesse continuado durante os séculos XVII e XVIII, tanto na Itália, quanto no restante da Europa.

A presença constante do arquiteto na obra e a individualização de sua profissão permitiu maior uso de desenhos como premissa para a construção. A partir de então foram sendo mais utilizadas as formas de representação gráfica em arquitetura, considerando-se apenas duas dimensões, como planta, elevação, seções e até mesmo perspectivas. O desenvolvimento apurado de desenhos de detalhes e de etapas da construção, foi tornando desnecessário o uso de modelos na execução da obra. O surgimento da perspectiva geométrica, com dimensões exatas e bem proporcionadas trouxe um esquecimento da prática de modelos físicos, que se tornaram escassos, mas nunca foram definitivamente abandonados.

A prática de modelagem não chegou à sua extinção, mas foi se transformando ao longo dos tempos, assim como as tecnologias e técnicas presentes na profissão de arquitetura. 
Brunelleschi e a cúpula de Santa Maria del Fiore A Basílica de São Pedro e a cúpula de Michelangelo 
Nesse capítulo serão apresentados dois exemplos do uso de modelos tridimensionais na arquitetura renascentista italiana. O primeiro é o projeto para a cúpula de Santa Maria Del Fiore, a catedral de Florença, do arquiteto Filippo Brunelleschi. O segundo relata a história da construção da Basílica de São Pedro, dando ênfase, principalmente à sua intensa atividade construtiva, e, conseqüentemente, ao desenvolvimento de técnicas de desenho e modelagem que a acompanharam. O exemplo de maior significação nessa atividade é a cúpula de Michelangelo, que, devido ao fato da sobrevivência de um grande modelo em madeira, suscitou dúvidas em relação à autoria do projeto executado.

A escolha de dois arquitetos italianos reflete uma maior documentação existente sobre o modelo no Renascimento Italiano, tanto em textos, quanto em imagens ou mesmo objetos que resistiram ao tempo e ainda se apresentam quase inalterados. Não se discute aqui a maestria e as características da arquitetura dos dois arquitetos, mas a importância do primeiro, por ter sido um dos precursores da Renascença e do uso do modelo; e do segundo, por ter realizado grandes e pequenos modelos, com diferentes materiais e detalhes. 
Filippo Brunelleschi, arquiteto, engenheiro, escultor e pintor, é considerado o pioneiro do Renascimento italiano. cúpula de Sant Maria Del Fiore

Brunelleschi nasceu em 1377 e era filho de um rico e respeitado homem de Florença, Brunellesco di Lippo, talvez como o que conhecemos hoje como diplomata ${ }^{1}$, e Giuliana di Giovanni degli Spini. Procurando criar o filho para sua Também foi um dos juízes substituição em um cargo semelhante, o pai de Brunelleschi concedeu-lhe uma educação muito remota aos jovens de mesma idade, da qual fazia parte o ensino de artes liberais. Quando sentiu atração pelas artes visuais, seu pai o levou à oficina de um famoso ourives, para que pudesse treinar, aperfeiçoar seus sentidos.

Brunelleschi ainda terminou seus estudos teóricos, principalmente matemática e mecânica, anos mais tarde, quando uniu técnica - conhecimento científico e teórico à prática, desenvolvendo, assim, "autodidaticamente as faculdades intelectuais que são tão peculiares à criatividade de sua obra como arquiteto". (HEYDENREICH, 1998, pág. 14).

Esse espírito humanista tão forte em Brunelleschi, do homem com conhecimento técnico e prático, e também sua autodidática, asseguraram-lhe o título de pai da perspectiva central, ou seja, com ponto de fuga. Embora Alberti tenha teorizado a perspectiva, foi Brunelleschi quem primeiro descobriu uma aplicação prática à teoria ótica da Idade Média.

Diferentemente de Alberti, que descreve essa teoria em seu tratado Da Pintura, Brunelleschi descobriu essas regras da perspectiva, tendo em mente, aplicá-las na arquitetura. “O uso

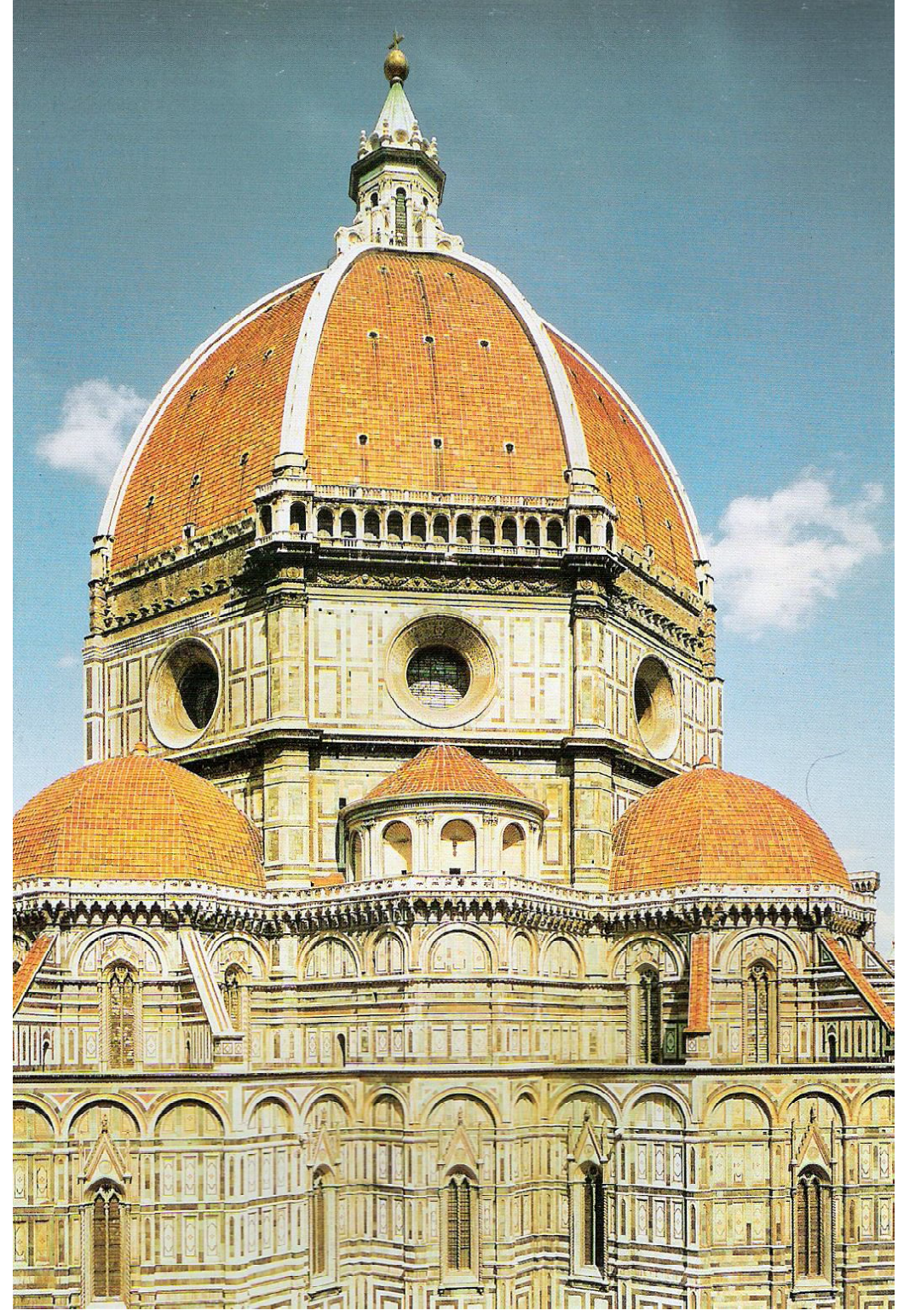

da perspectiva linear no desenho de arquitetura é um componente do estilo de Brunelleschi e um fator essencial em suas inovações". (HEYDENREICH, 1998, pág. 14).

Figura 67

A catedral de Florença idealizada e inicialmente executada por volta do século XIII, representava a sociedade de sua época, e estava inserida em um modelo de cidade (regime comunal) então vigente, bem diverso daquele (século $\mathrm{XV})$ que estava se instaurando no momento da construção de sua cúpula (regime senhorial, onde a cidade pretendia ser a capital do Estado que estava se consolidando). 
Para a construção do Duomo de Florença, no século XIV, havia sido concebido um projeto, aceito por uma comissão de oito arquitetos, que vinculava toda a obra futura. Para garantir sua integridade, todo mestre que se tornasse responsável pela construção, deveria realizar um juramento em respeito a esse projeto, inclusive Brunelleschi, posteriormente.

Em 1367, a construção da catedral estava completa até o tambor da cúpula, obra do mestre Arnolfo di Cambio, que deixou um modelo em alvenaria, da cúpula, próximo ao campanário de Giotto. Tal modelo ainda existia na época de Brunelleschi. Essa cúpula de Arnolfo não foi construída porque a técnica empregada (cimbramento) já havia desaparecido, devido à crise $^{2}$ que atingiu os canteiros de construção medievais.

Nos mesmos anos de construção da catedral de Florença, também estava sendo construída a catedral de Milão, um projeto programaticamente gótico e que pretendia unir o gótico alemão, francês e italiano, na tentativa de criar um estilo que futuramente seria o gótico internacional

Brunelleschi, e seus contemporâneos, Masaccio e Donatello procuravam responder sempre a essa tentativa de europeizar a Itália. Afirmavam a unidade formal contra a multiplicidade de gostos presente no gótico internacional, cuja representação em Florença era de Gentile da Fabriano (ARGAN, 1999).

Quando instaurado o concurso para um projeto e execução da cúpula, em 1418, as condições políticas e sociais estavam ainda mais diferentes que aquelas do século anterior.
E isso gerava um conflito muito grande na concepção do projeto. Poderiam ser consideradas três formas de completar a construção da catedral: a continuação, a partir do projeto deixado por Arnolfo; reinterpretá-la segundo suas características e alterando-a, de vez, com as novas idéias que estavam surgindo.

Figura 68

Além de o grande modelo tridimensional anunciar a majestosa forma da cúpula, os planos para a construção forneciam grande entendimento do problema e garantiam sua plena execução. Esse foi o motivo de o projeto vencedor ter sido o de Filippo Brunelleschi e Lorenzo Ghiberti. Embora fosse um projeto realizado em conjunto, Brunelleschi levou todo o mérito, devido ao seu grande conhecimento de mecânica e matemática, empregado na construção. Dessa forma, ficou como o superintendente da obra, desde seu início - 1420, até o fim - 1436, e depois, na construção do lanternim da cúpula, até sua morte em 1444.

Brunelleschi e Ghiberti resolveram conceder à catedral 3 Moderno era sempre tribuído a algo que rompe o que era feito considerasse sua história, ou seja, respeitasse sua construção relaciona-se sempre com o existente. Era necessário criar uma cúpula que desse um que era feito antes. Será usado termo nesse sentido, sem considerar a existência atual de um movimento que leva esse nome. significado para as novas aspirações político-sociais, apresentando-se como o emblema de uma cidade que estava ampliando seus limites, assim como um marco sobre a cidade medieval.

Em 1418, ano do concurso, a construção da cúpula representava um problema que poderia ser dividido em dois aspectos mais importantes: técnico e estético.

O aspecto técnico representa o que fez da cúpula um 


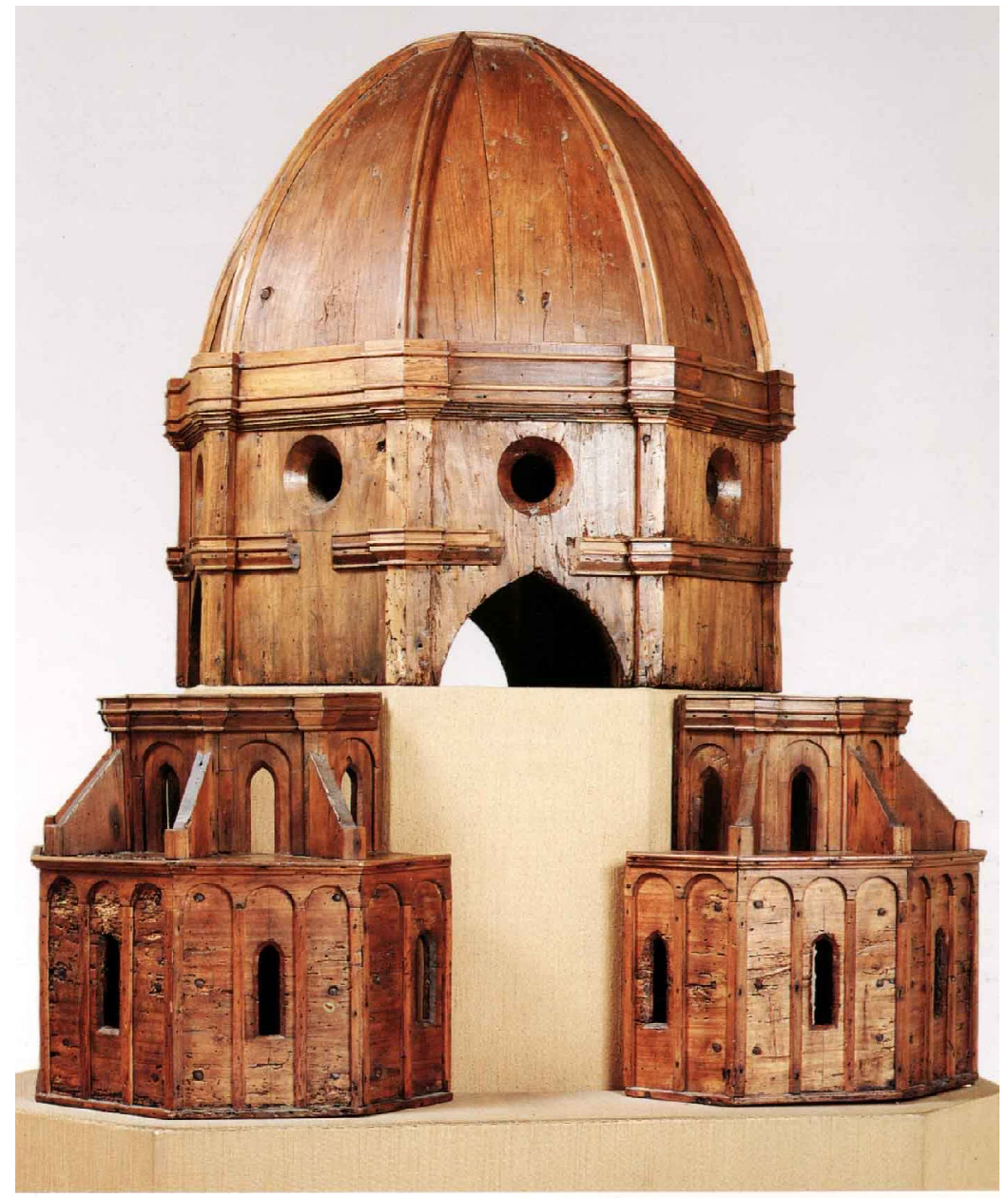

símbolo de modernidade e de inspiração para os novos artistas, isto é, a elevação da cúpula sem a necessidade de cimbramento $^{4}$. Brunelleschi, ao invés de procurar a técnica usada até o século XIII, por muitos carpinteiros, propôs uma nova invenção que garantisse que a cúpula fosse executada se auto-sustentando durante a construção, ou seja, sem a ajuda de qualquer cimbramento.

A genial solução de Brunelleschi foi a de construir duas cúpulas, uma interna e outra externa. A cúpula externa apóia seus vinte e quatro suportes elevados sobre os "dentes" da cúpula interna.

Essa nova invenção de Brunelleschi não possibilitava o uso de velhas técnicas de construção e nem de antigos mestres

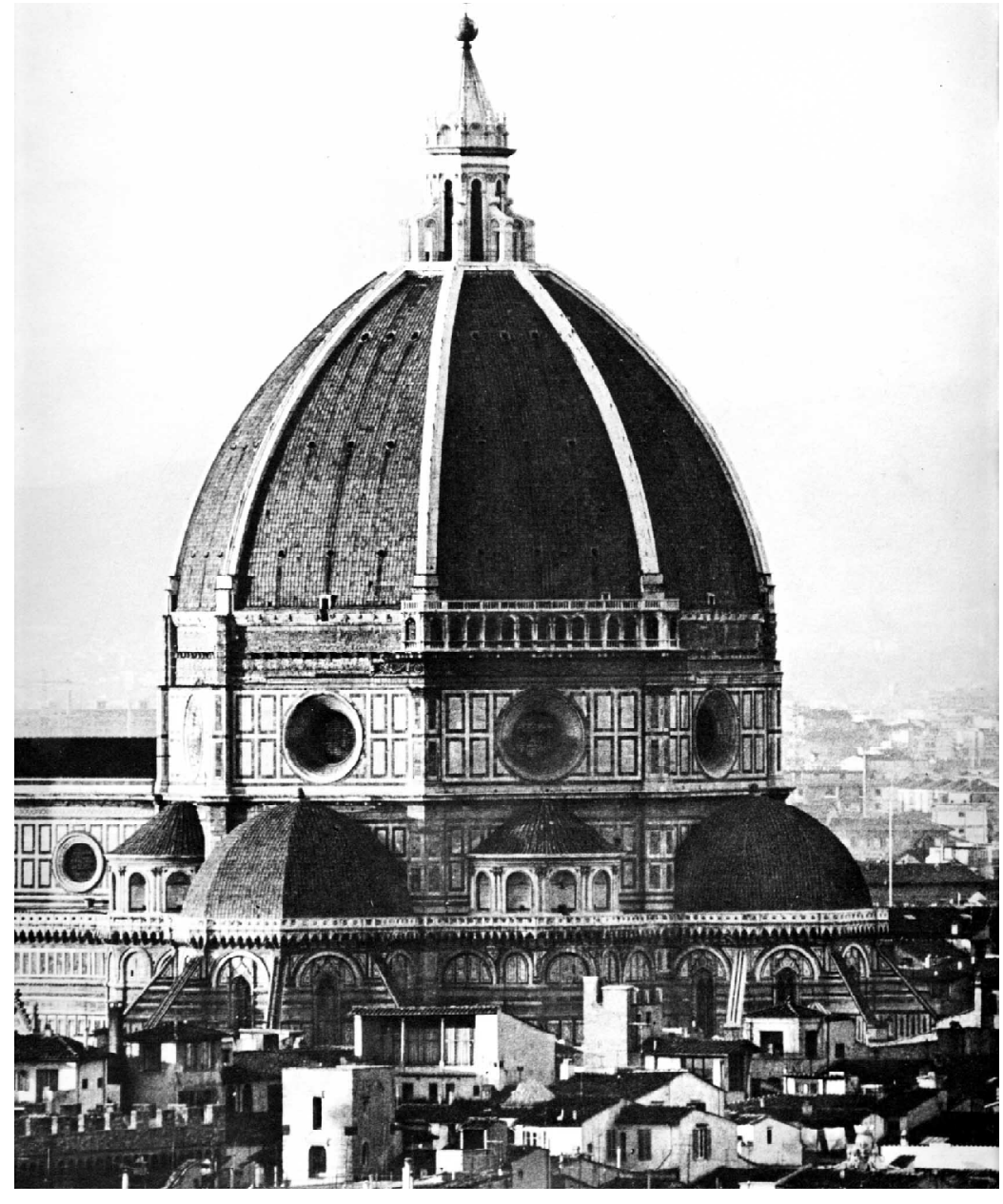

possibilitar o movimento, em caso de terremoto, sem gerar danos à estrutura.

${ }^{4}$ Cimbramento era um lécnica de construção usada que para erguer uma cúpula randes peças de madeir (cimbres), que serviam como ma sustentação da cúpula té seu fechamento final. pós a construção esta ta, esse madeiramento

69 - A cúpula da catedral de Florença. (MURRAY, 1972, p.23).

Quanto à estética, a cúpula não se limita a completar a obra, mas a garantir sua coerência, sua unidade com o que já estava executado, além de assegurar à obra total uma nova significação, conforme o desejo da nova sociedade. Brunelleschi apresenta toda essa característica em seu projeto. Estuda o edifício, a fim de estabelecer proporções e equilíbrio entre o que estava construído e a cúpula. "Com o amplo corpo da cúpula coordena e conclui os espaços radiais do coro, enquanto que com o perfil ogival equilibra em altura o espaço longitudinal da nave e com a convergência das nervuras define as formas da cúpula (...)" (ARGAN, 1987, p. 121)

Havia ainda um simbolismo na cúpula de Brunelleschi. 


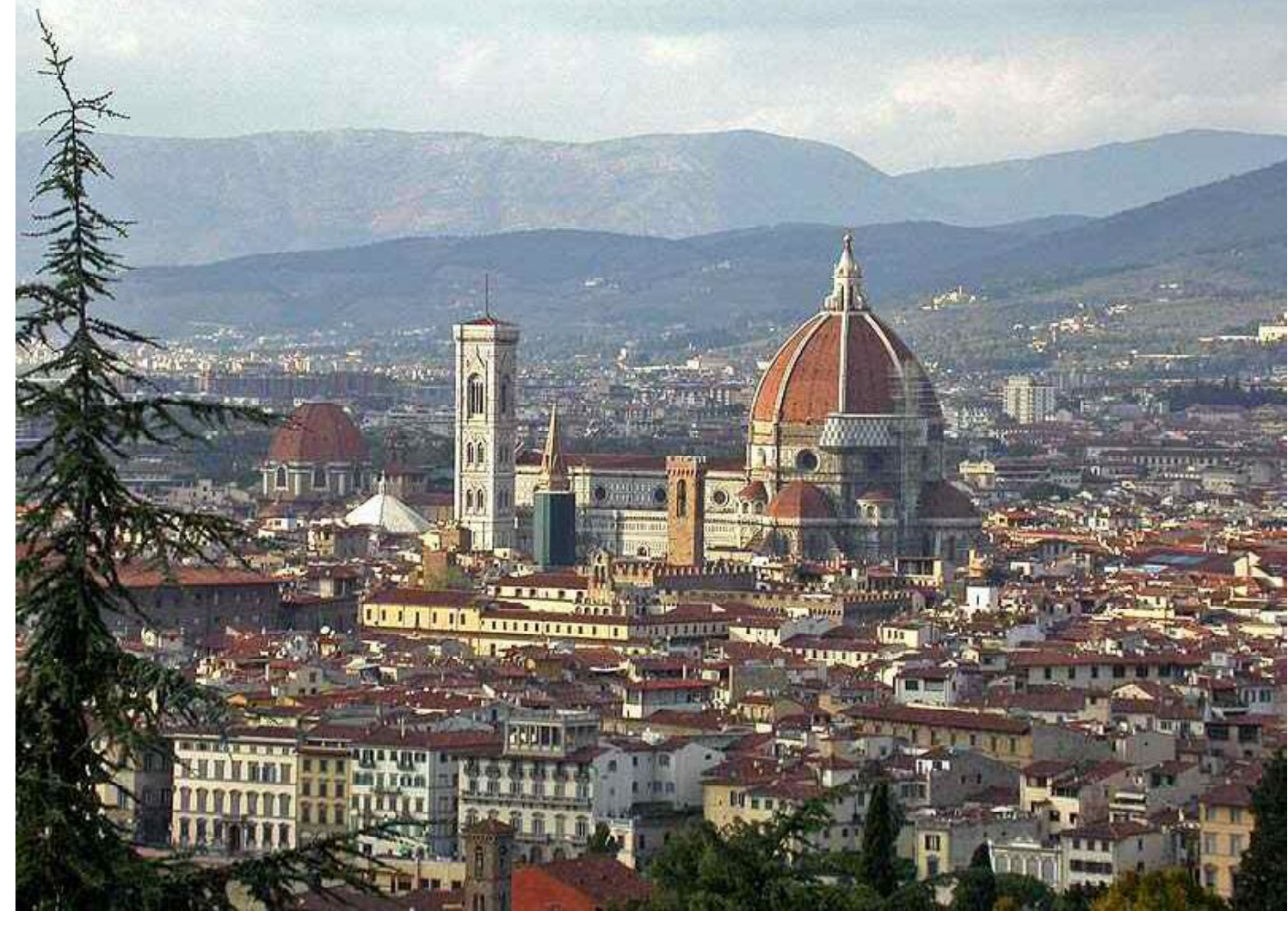

Era uma espécie de coroação da Virgem, o qual era Figura 70 - Vista panorâmica dedicado o Duomo de Florença. A cúpula, que poderia ser vista ao longe, foi descrita por Alberti, como uma obra que parecia cobrir com sua sombra todo o povo toscano.

Interessante o fato de que a cúpula proposta por Arnolfo di Cambio fosse clássica (hemisférica, pesando sobre o tambor), enquanto a de Brunelleschi fosse de seção ogival, lembrando o gótico. Na verdade, a cúpula de Brunelleschi não representava o gótico, principalmente porque sua técnica nada tinha de medieval, mas buscava um significado preciso, que Figura 71 através da forma havia sido revelado: elevou a parte central do edifício, deixando a nave longitudinal com menor importância, além de ter conseguido imprimir à cúpula, uma leveza, que a tornava claramente apoiada sobre o edifício. As linhas de força das nervuras, que correm para o lanternim, evidenciam essa transferência de forças que Brunelleschi queria apresentar, como se a abóbada da cúpula fosse um meio
Figura 71 - Catedral de Florença - construção da cúpula. (HEYDENREICH, 1998, p.13)

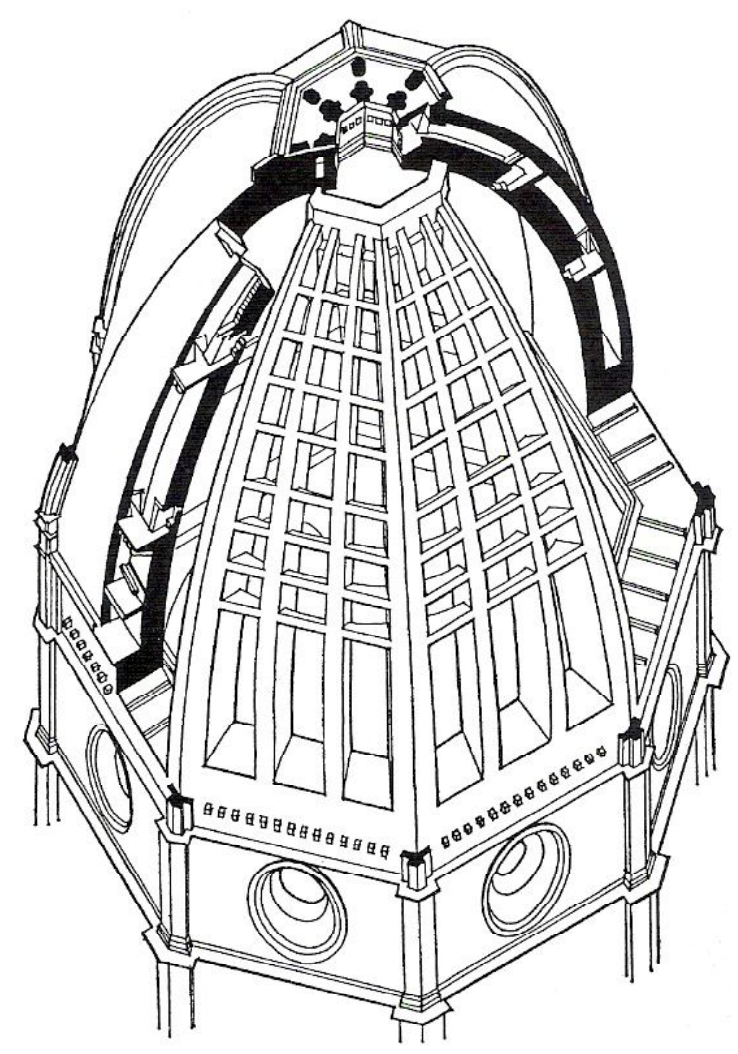

para o caminho dessas tensões. A convergência das linhas das nervuras também pode ser interpretada segundo a perspectiva central, que Brunelleschi mesmo anunciou.

${ }^{5}$ A cúpula tinha 46 metros de diâmetro e 56 de altura até a base do lanternim.

${ }^{6}$ Fato importante porque coloca a figura do arquiteto no canteiro de obras, diferente da Idade Média quando somente eran responsáveis os "mestres de
Uma cúpula 'perspectiva' não é um objeto colocado no espaço, mas uma forma que representa o espaço inteiro e que, portanto, possui uma capacidade teoricamente ilimitada; por isso, a cúpula é a cobertura ideal da cidade inteira, que é posta em relação com o horizonte dos morros circundantes, sobre os quais parece apoiar-se a cúpula natural do céu. (ARGAN, 1999, p.66).

A grande dimensão da construção ${ }^{5}$ fazia com que Brunelleschi tomasse conta de toda a construção ${ }^{6}$, onde escolhia as melhores pedras, uma a uma, para assegurar sua 
perfeição, mantinha-se na obra todo o tempo, fornecendo modelos tridimensionais em cera ou argila e desenhos para explicar aos "operários", inclusive em como amarrar as pedras, ou seja, o travamento em espinha de peixe (uma técnica utilizada pelos romanos e de seu conhecimento devido às investigações que fazia nas ruínas).

A postura de Brunelleschi é uma afirmação típica de individualismo, uma invenção fundada numa escolha cultural (...). Brunelleschi substituiu a experiência operacional da tradição gótica pela experiência cultural, substituiu a continuidade da tradição pelo julgamento histórico. Sua invenção é, portanto, tecnológica, mas claramente inserida no âmbito da cultura humanista, que buscava uma relação contínua com a história (...). (ARGAN, 1999, p. 49).

O historiador Goldthwaite conta-nos que segundo Manetti

Brunelleschi frequentemente fazia modelos de detalhes para seus trabalhadores, um deles refere-se a um contrato de Innocenti com um escultor para a arquitrave, cornija, e oculum da 'loggia, embora (Manetti acrescenta) ele algumas vezes relutasse em fazer isso, com receio de ter suas idéias roubadas. (GOLDTHWAITE, 1980, p.376).

Há também uma passagem interessante no texto de

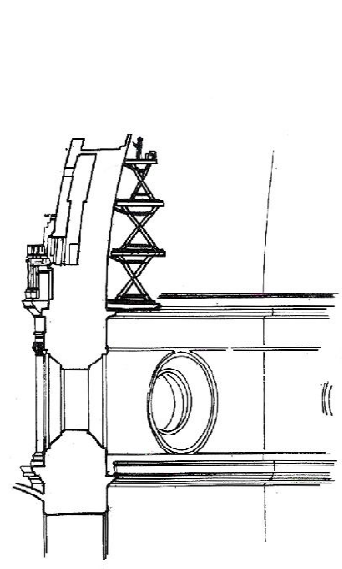

Figura 72 (acima) - esquema da fixação dos andaimes projetados por Brunelleschi, para o início da cúpula.
(MONDADORI, 1988, p.251).

Figura 73 (direita) - esquema da fixação dos andaimes projetados por Brunelleschi, para o comeco da curvatura da cúpula. (MONDADORI, 1988, p.251)
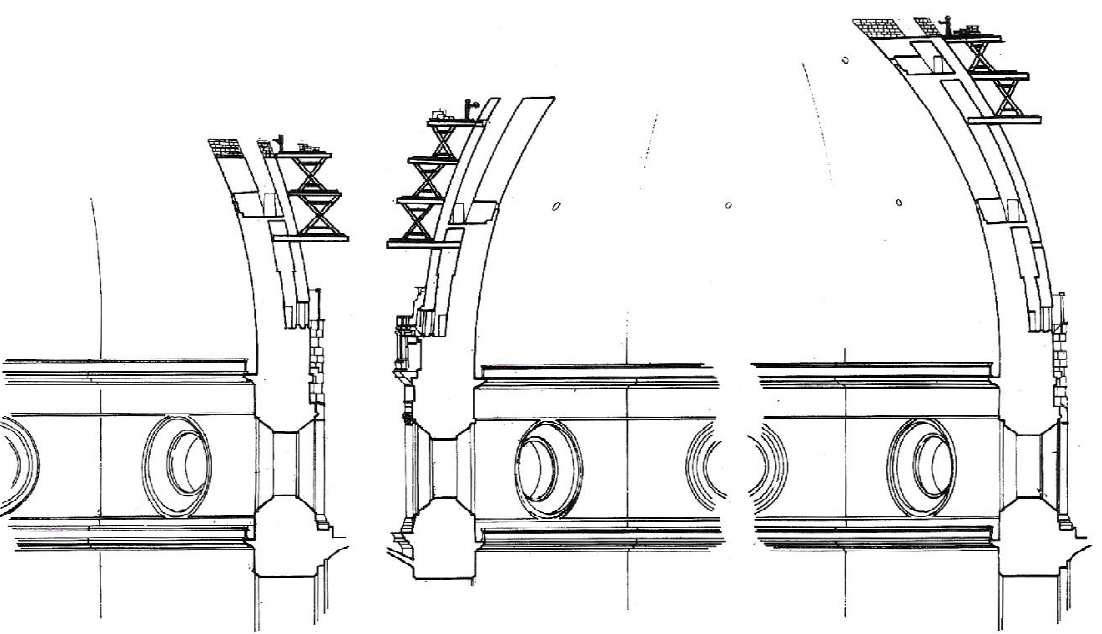

Vasari que conta que quando a construção já estava bem avançada, bem alta, os trabalhadores perdiam muito tempo descendo para comer e beber, principalmente pelo incômodo gerado pelos dias quentes. Para resolver essa situação, Brunelleschi mandou abrir uma taverna com cozinha na úpula, e também servir vinho a todos os trabalhadores. Dessa forma, conseguiu que todos somente fossem embora no final da tarde. Apesar de estranha, essa atitude foi de grande utilidade na obra.

Odomínio de técnicas era tão presente em Brunelleschi

Figuras $72,73,74$ e 75 que, quando solicitado por um andaime que fosse seguro para construir a parte final da cúpula, já em forma bem angulosa, ele próprio projetou e mandou executar um tipo de andaime que ficasse solto do chão e preso em apoios na cúpula interna. Para a elevação de pedras e outros materiais necessários, Brunelleschi também projetou uma espécie de instrumento que, funcionando como um relógio (baseado em sua primeira profissão), havia um centro, com um tronco na vertical e outro atravessado na horizontal, como um braço, que rotacionado por um par de cavalos, gerava movimentos para frente e para trás, que garantia a elevação e descida de um suporte que 

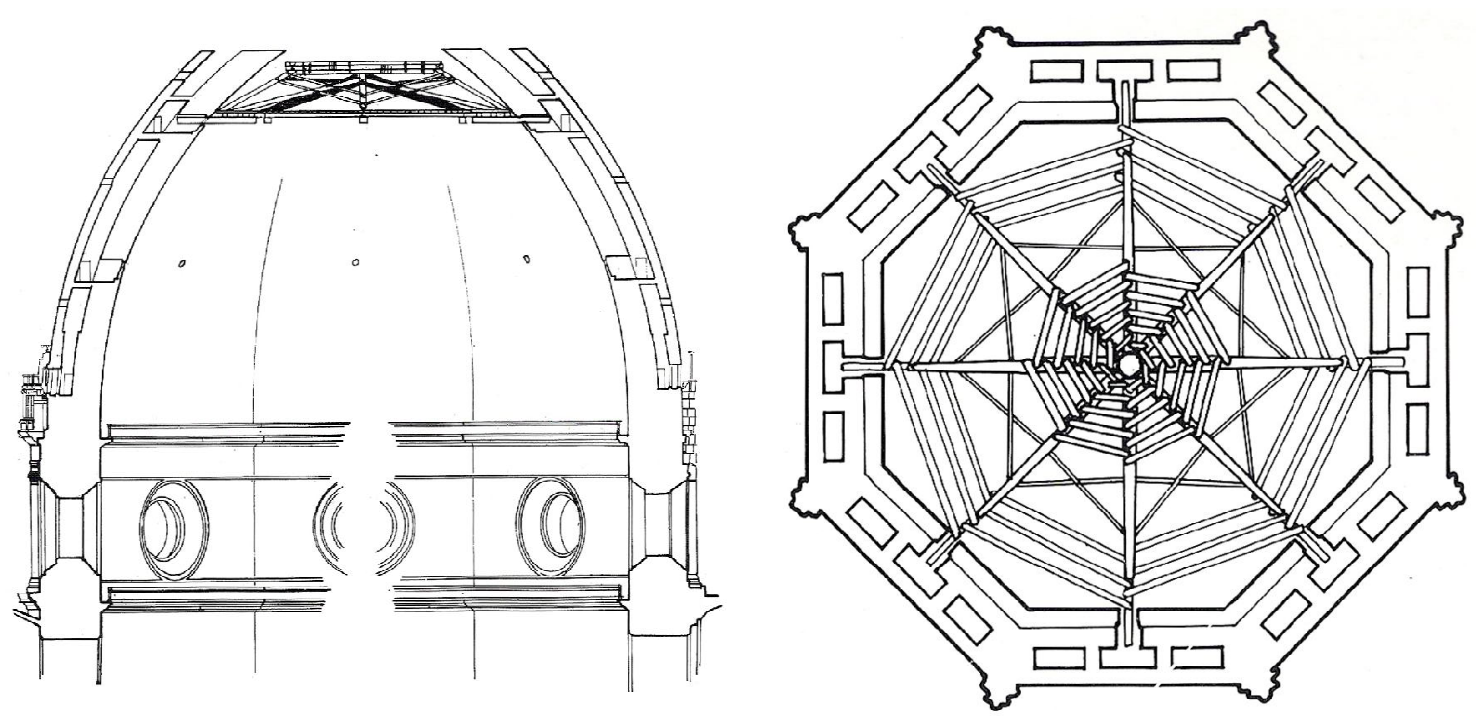

carregava esses materiais, de dez em dez metros.

A construção da cúpula terminou em 1436. Por causa da inveja que os construtores de ofício sentiram pela ascensão de Brunelleschi com a construção da cúpula, houve um novo concurso para a construção do lanternim que iria coroá-la.

Nesse mesmo ano, Brunelleschi, Ghiberti e muitos outros arquitetos da época fizeram modelos para o lanternim da cúpula. O projeto escolhido, incrivelmente, foi novamente o de Ghiberti e Brunelleschi, que faleceu sem ver o término de sua obra.

O lanternim da cúpula apresenta duas funções, uma Figuras 76 e 77 estática, técnica, na qual significa o fechamento superior, necessário ao travamento de toda cúpula; e outra figurativa (ARGAN, 1999), que simboliza o ponto central da cúpula, ou mesmo, o seu eixo. E, como dito anteriormente, reforça a idéia de convergência das linhas perspectivas.

Com exceção desse lanternim para o Duomo de Firenze, a maioria dos modelos de Brunelleschi eram feitos de forma incompleta, sem os elementos decorativos, para

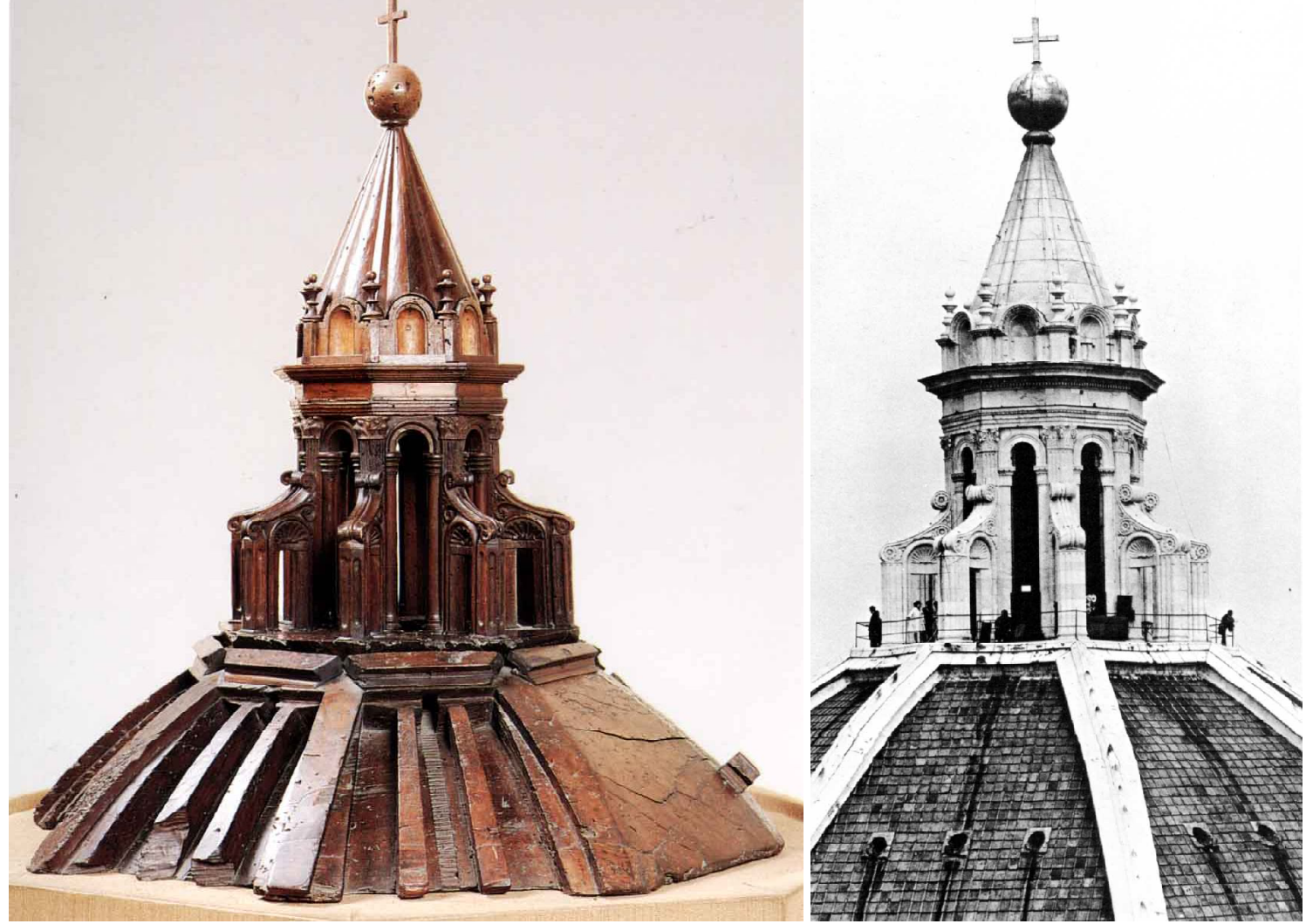

Figura 76 (acima) - Modelo intencionalmente mostrar apenas as informações e relações construtivas entre as paredes e seus elementos principais. em madeir da cúpula. Brunelleschi. (MILLON e LAMPUGNANI, 1994, p.22).

Manetti, em sua biografia sobre Brunelleschi, quando ainda

Figura 77 (direita) - o

anternim da cúpula da cate-

dral de Florence (MURRA

ral de Florenca. (MURRAY,

1972, p.34)

A natureza de Fillipo, ou melhor, seu costume em relação aos modelos, após ele ter alguns anos de experiência em arquitetura, era de que os modelos para suas construções eram feitos revelando pouco sobre suas dimensões, mas ele preocupava-se com a construção das paredes, em mostrar a relação entre alguns membros, sem ornamentos, capitéis, arquitraves, frisos, cornijas, etc. (ETTLINGER, in: Kostof, 1977, p.109). 
Nesse segundo exemplo percorreremos a construção da Basílica de São Pedro, no Vaticano, em Roma. Importa-nos a história de seus arquitetos e construtores, enquanto trabalharam nessa obra. Embora saibamos das alterações presentes em cada projeto, bem como a intenção de cada arquiteto, não nos deteremos a descrever profundamente os projetos concebidos, pois nosso maior interesse é a seqüência na história da representação gráfica e tridimensional da arquitetura, que se revela por traz desses longos anos de construção e de tão gloriosos projetos. No projeto para a cúpula, proposto por Michelangelo, faremos uma explanação sobre suas principais características e mudanças sofridas por Della Porta, que acabou por executá-la assim como se encontra hoje.

A Basílica de São Pedro conforme se encontra

A Basílica de São Pedro

atualmente no Vaticano é resultado de um processo longo de construção. Sob o poder do papa Julio II, a antiga construção Constantina, sofreria uma renovação para "provê-la, em decoroso estilo, de capelas e outras dependências necessárias".(LOTZ, 1998, pág. 17).

A construção da Basílica de São Pedro tem uma história muito rica de projetos dos melhores arquitetos do período Cinquecento (século XVI). Sua execução foi iniciada por Bramante, por volta de 1506, sendo substituído após sua morte, por Rafael, em agosto de 1514, tendo Antonio da Sangallo, o Jovem, por assistente. Nessa mesma época, Baldassari Peruzzi, também trabalhou na obra até 1520. Após a morte de Rafael, em 1520, Antonio da Sangallo, o Jovem tornou-se o encarregado por mais de vinte e cinco anos, até sua morte em 
setembro de 1546. Michelangelo foi designado seu sucessor em novembro do mesmo ano, sendo oficializado apenas em janeiro de 1547, e ficou no cargo até sua morte, em fevereiro de 1564. Por dezessete anos, essa construção foi a maior preocupação de Michelangelo. Em seguida, foi substituído por Pirro Ligorio, rapidamente destituído do cargo em outubro de 1565, pelo fato de ter tentado alterar o projeto de Michelangelo. Após sua saída, Vignola assumiu a responsabilidade até sua morte, em julho de 1573, quando Giacomo Della Porta encarregou-se do término da construção da Basílica, de sua cúpula (1586-90), e de seu lanternim, encerrando a obra em 1593.

Apesar da planta executada não corresponder exatamente a nenhum projeto conhecido, acredita-se que seu mentor, e primeiro executor, tenha sido mesmo Bramante, devido à escolha pelo arquiteto, feita por Julio II.

Em 1514, Bramante faleceu e deixou a construção da basílica em curso. Sua maior preocupação era o término da igreja conforme havia sido planejada por ele, principalmente a cúpula. Deixou modelos e especificações a seus alunos e sucessores quanto às vistas externas e internas que a cúpula deveria resultar. O projeto de Bramante uniu idéias antigas a um novo repertório que havia aparecido recentemente. “Bramante fundiu a força expressiva da arquitetura da Antiguidade com a tradição da liturgia cristã e dos edifícios memoriais, e o resultado foi uma forma que permaneceu como o ideal de construção eclesiástica até a era do classicismo". (LOTZ, 1998, pág. 20).

Acredita-se que a única planta, de forma central, desenhada a Figura 78 mão por Bramante seja a do pergaminho, presente em Florença.
Figura 78 - Donato Bramante. Projeto para a basílica de São Pedro, planta. (LOTZ, 1998, p.18)

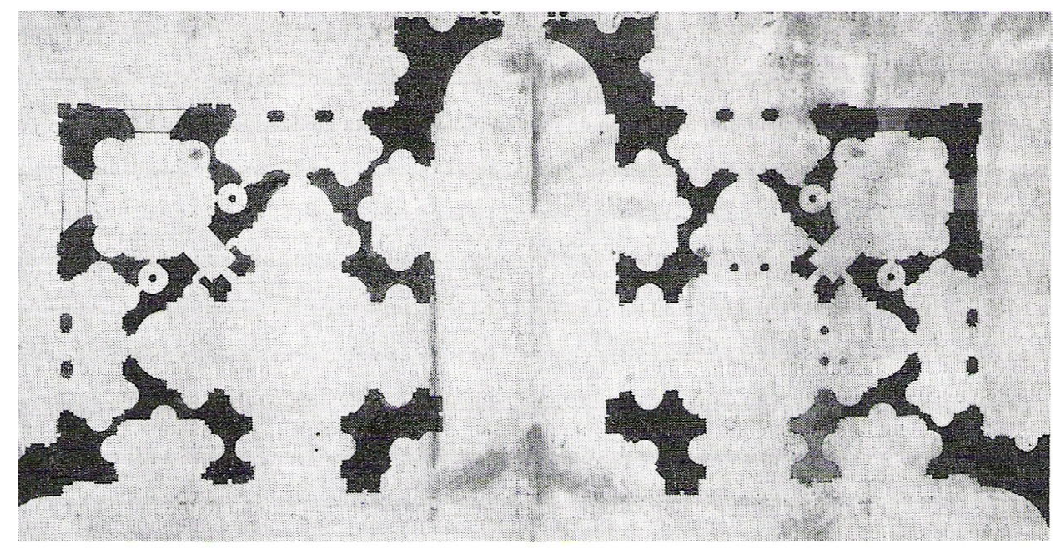

Os sucessores de Bramante tinham alguns problemas como herança na obra, rachaduras nos pilares e deslocamento de alicerces, devido ao terreno instável. Além da morte de Bramante, o papa Julio II também havia morrido, um ano antes. Em seu lugar, assumiu o papa Leone $\mathrm{X}$, que sem nenhum projeto para servir de guia na continuação da Basílica, ordenou a primeira tarefa de Rafael, conceber um modelo em madeira, que, infelizmente, perdeu-se. Além desse primeiro projeto, outros vários seguiram nessa fase de confusão que reinava entre os arquitetos após a morte de Bramante.

Figuras 79 a 83

Embora o interesse do papa Leone X pela construção da basílica fosse menor do que do papa Julio II, o que fazia com que a obra andasse lentamente, durante seu pontificado foi definido um método de trabalho que permaneceu até o fim da construção, em 1590. Antes desse momento, o projeto e a supervisão da obra ficavam sob o poder de uma só pessoa, com o papa Leone $X$, foi criado o cargo de assistente, o qual ficaria responsável pelo planejamento e pela execução dos desenhos na obra. Esse cargo era ocupado por Antonio da Sangallo, o Jovem, enquanto Rafael era o superintendente de projetos. Após a morte desse último, Antonio da Sangallo foi promovido a seu cargo. 


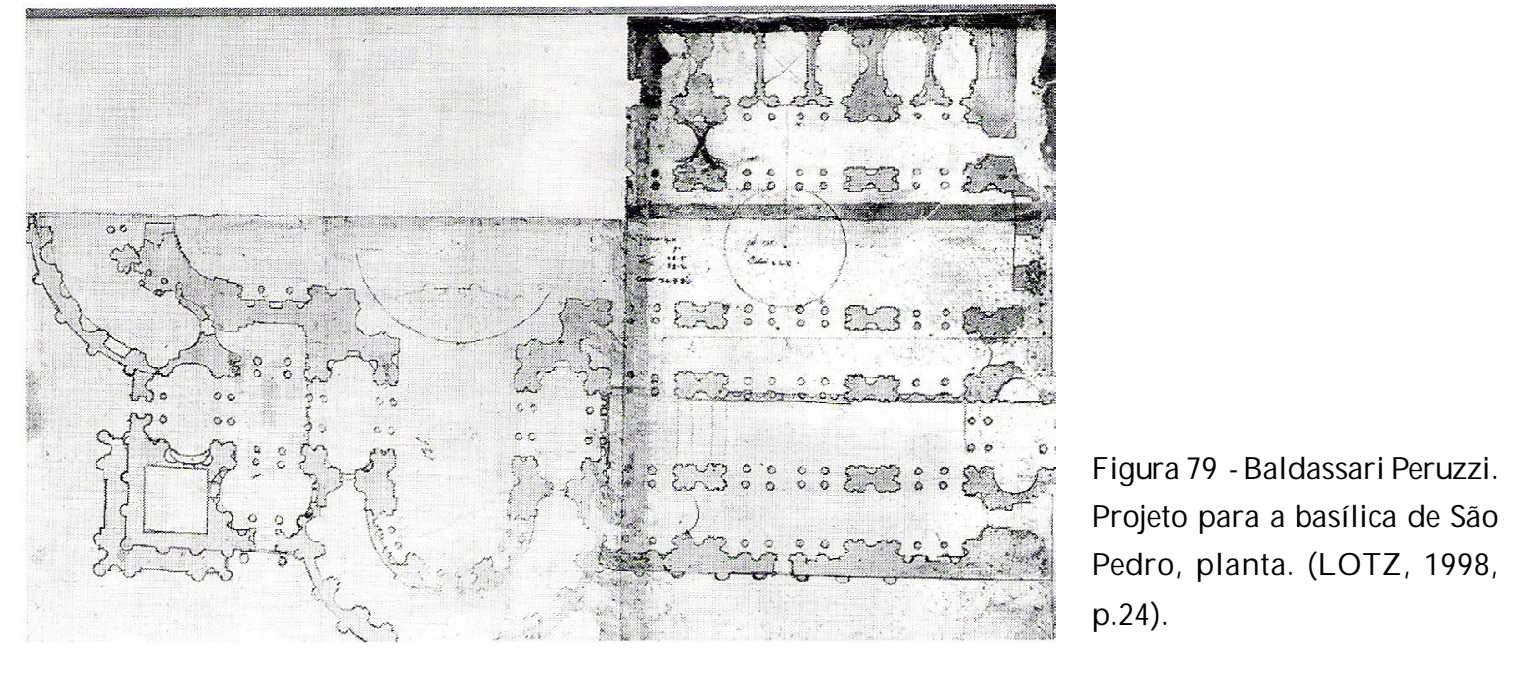

O método de projeto e construção utilizado por Bramante era baseado em um modelo tridimensional do edifício, que era apresentado para o papa e depois para os mestres, pedreiros e entalhadores, para então marcar a planta no local (mistura entre o método medieval e o uso de maquetes, preconizado no Renascimento). O arquiteto explicava todas as informações aos seus trabalhadores e em caso de necessidade, fazia pequenas maquetes de detalhes, até em tamanho natural, de capitéis, molduras, e outros. No início do século XVI, alterou-se esse método de projeto, além de maquete e planta, aumentou-se o uso de elevações para o planejamento e para a execução.

“Rafael, que planejava suas pinturas em desenhos sistemáticos e precisos, deve ter concluído que o projeto para o edifício, recebido por Bramante, não podia ser executado apenas com uma maquete uma planta."(LOTZ, 1998, pág. 31).

Rafael defendia o uso do sistema de representação gráfica de planta, elevação vertical e corte com projeção ortogonal. Para ele, esse era o método necessário do arquiteto para representar seu projeto e garantir as corretas dimensões e proporções para seus executores. Rafael, como visto

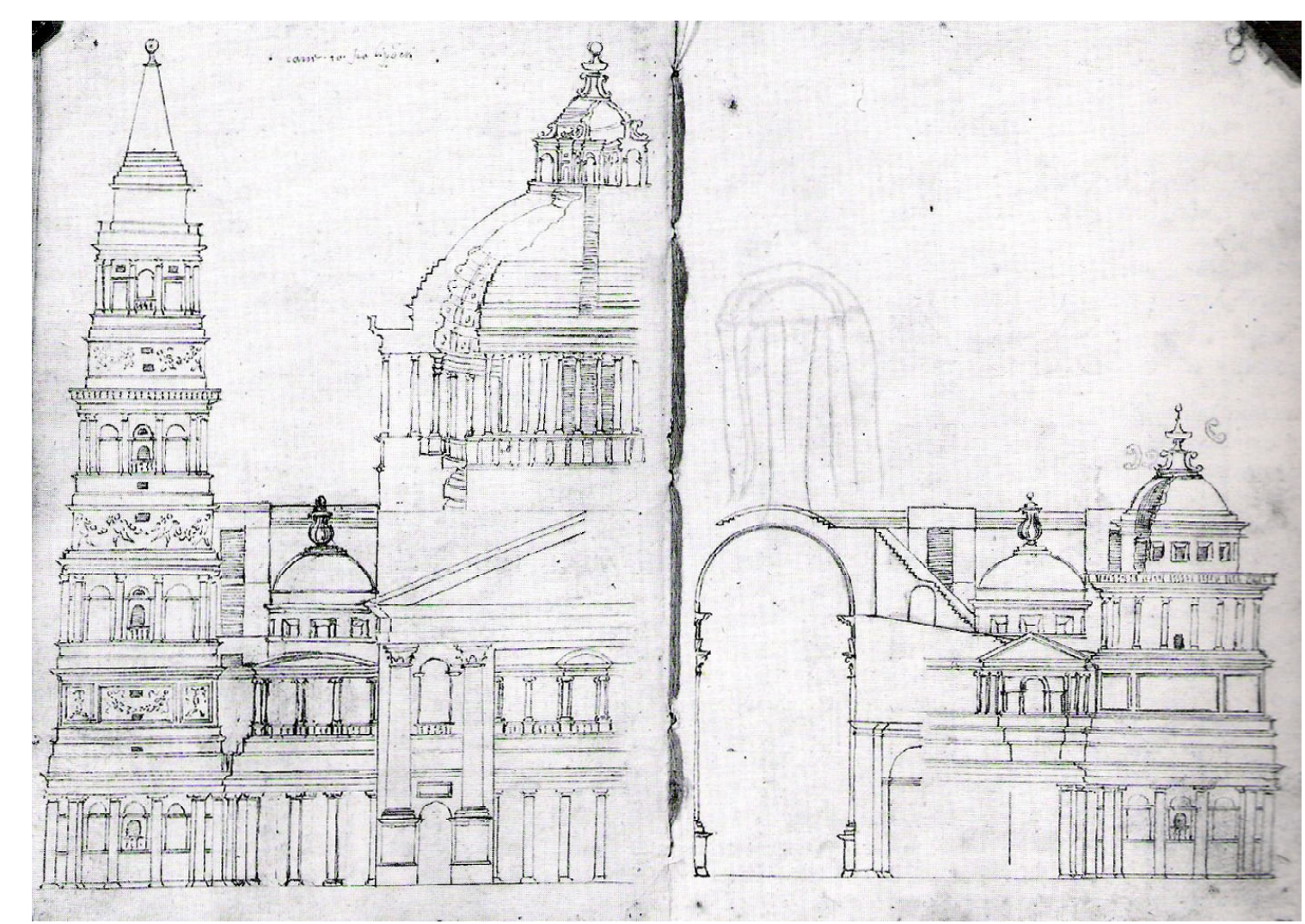

Figura 80 - Rafael (cópia). Pro- anteriormente, formulou nesse período uma carta ao papa jeto para a basílica de São
Pedro, elevação e corte. Leone $X$, explicando seu novo método de projeto, justificando (LOTZ, 1998, p.24). e especificando cada etapa. Esse documento não só define o sistema gráfico mais próximo do atual, como também evidencia a vontade de Rafael de abandonar a configuração perspectivada do espaço de Bramante (o qual queria repetir na Basílica sua forma de representar do Tempietto). Para Rafael era necessário dar importância a cada elemento em separado, apreendendo-o totalmente, claro, sem se distanciar de seu conjunto. Porém, para ele, a visão única do espaço deveria ter seu fim. Isso pressupôs que, com os desenhos definidos, não era mais preciso ir ao canteiro e explicar o projeto aos executores. O desenho e a execução encontram, portanto, sua dissociação.

Apesar de muitas diferenças, o projeto de Rafael conformou-se à planta final do projeto de Bramante, contudo, empregou-lhe uma forma final em $\mathrm{T}$, configurando uma forma 

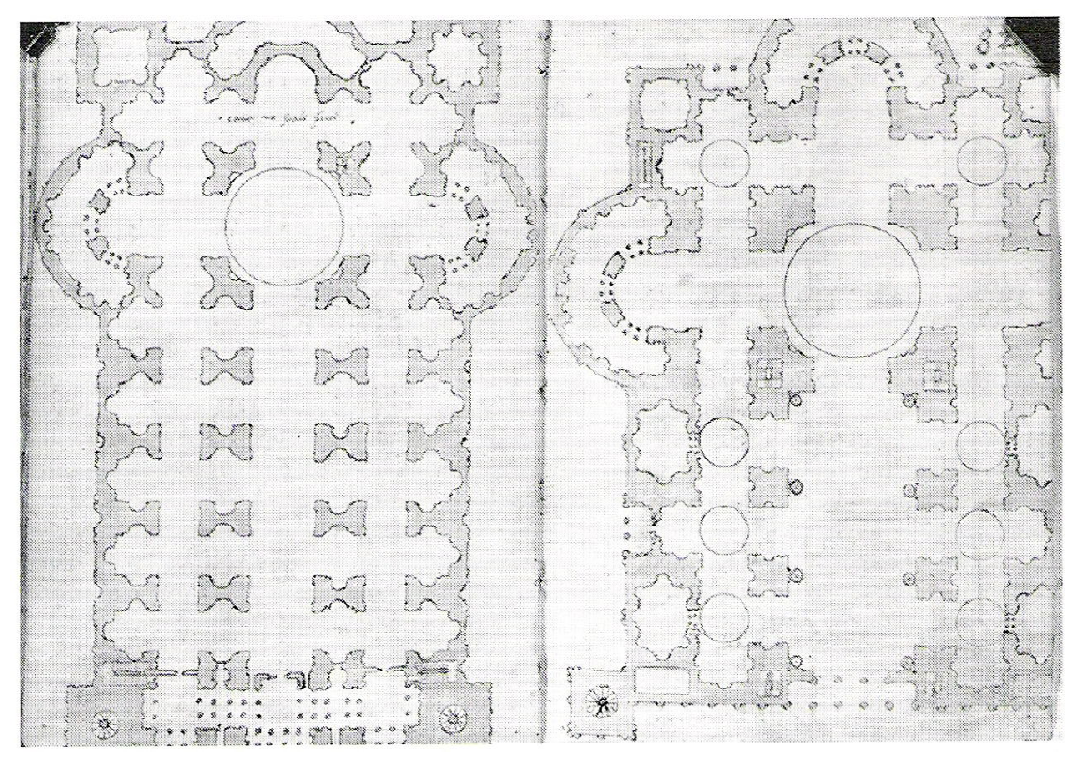

Figura 81 - Rafael (cópia). Proeto para a basílica de São Pedro, planta. Antonio da Sangallo (cópia). Projeto para a mesma basílica, planta. (LOTZ, 1998, p.25)

Em 1520, com a morte de Rafael, Antonio da Sangallo assumiu o cargo, principalmente por ser considerado o maior perito em construção na época.

Antonio da Sangallo, o Jovem, que substituiu Rafael, não concordava com o último projeto para a Basílica de São Pedro, como pode ser visto na Figura 81. Apenas considerava interessante a relação entre a nave e a cúpula, ou seja, a forma de basílica, o percurso entre a entrada e o altar, onde se encontra o túmulo do apóstolo São Pedro, o símbolo pelo qual foi erguida a basílica.

O saque de Roma, 1527, fez com que houvesse um êxodo artístico de Roma. Com isso, todas as construções ficaram praticamente paralisadas, inclusive a basílica de São Pedro. O retorno às atividades aconteceu no pontificado de Paulo III (1534-1549), quando um novo florescimento artístico ocorreu. Os novos edifícios, de 1540 e 1550 diferenciavam-se totalmente do estilo de Bramante e Rafael. Nesse momento, a cidade de Florença e o norte da Itália ditavam esses novos estilos.
Figura 82 - Rafael. Projeto para a basílica de São Pedro, corte do deambulatório e elevação do transepto, desenho de Antonio da Sangallo, o Jovem. (LOTZ, 1998, p.25).

Figura 83 - Antonio da Sangallo, o Jovem. Projeto para a basílica de São Pedro, planta. (LOTZ, 1998, p.25).
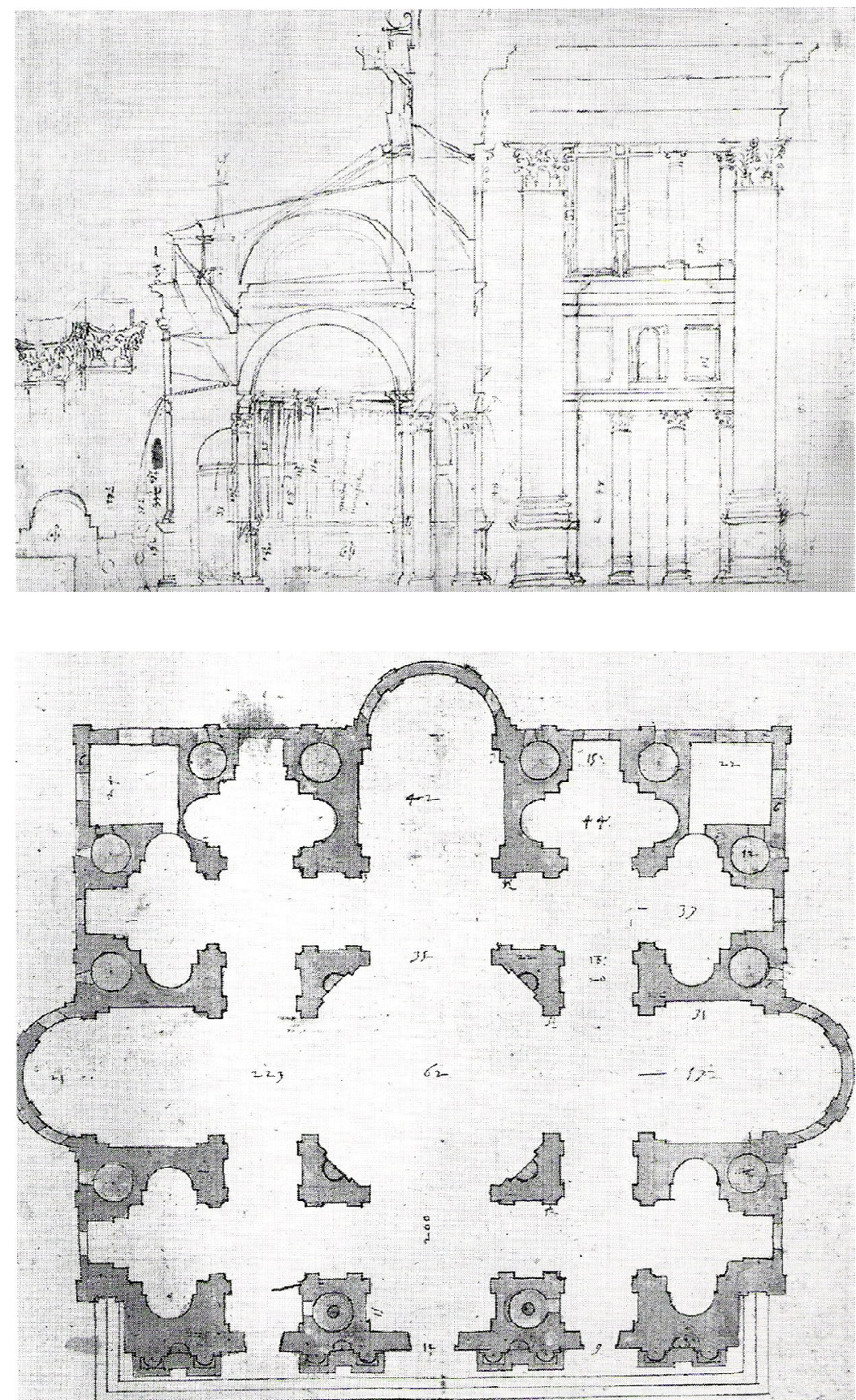

Em 1536, uma carta do papa Paulo III nomeou Antonio da Sangallo superintendente perpétuo da construção da basílica.

Figuras 84 a 86

Em 1539, foi encomendada uma maquete do "novo" projeto para a basílica, a Antonio da Sangallo.

O modelo de Antonio da Sangallo para a Basílica de São Pedro é o maior modelo renascentista italiano existente 


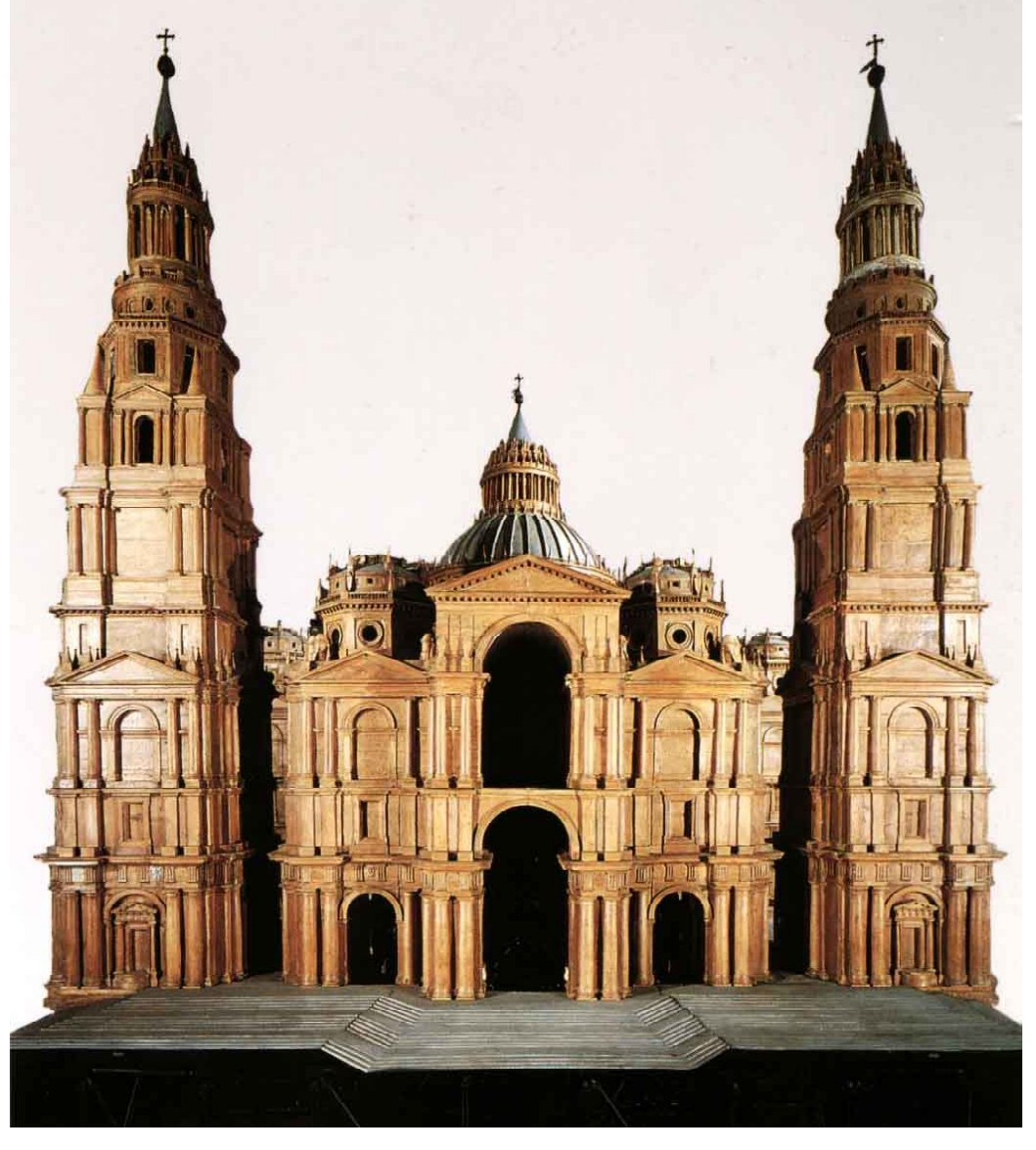

na atualidade. Foi construído por Antonio Labacco e se encontra atualmente dentro da própria Basílica, em Roma. Sua construção durou mais de sete anos (1539-1546) e serviu como um exemplo definitivo do projeto de Sangallo para a Basílica e seria também utilizado de guia na construção da obra. Representa um modelo completo, muito caro por seu trabalho e pela quantidade de material aplicado.

O modelo, tão grande a permitir o acesso ao interior, foi realizado para demonstrar, de modo bem detalhado, o interior e o exterior da Basílica. As abóbadas do transepto e da nave, por exemplo, incluíam a decoração em caixotões, desenhados em relevo sobre folhas de papel, coladas à superfície de madeira curva da abóbada. No interior os elementos arquitetônicos eram pintados em amarelo e o restante em cinza claro, provavelmente, tentando simular o

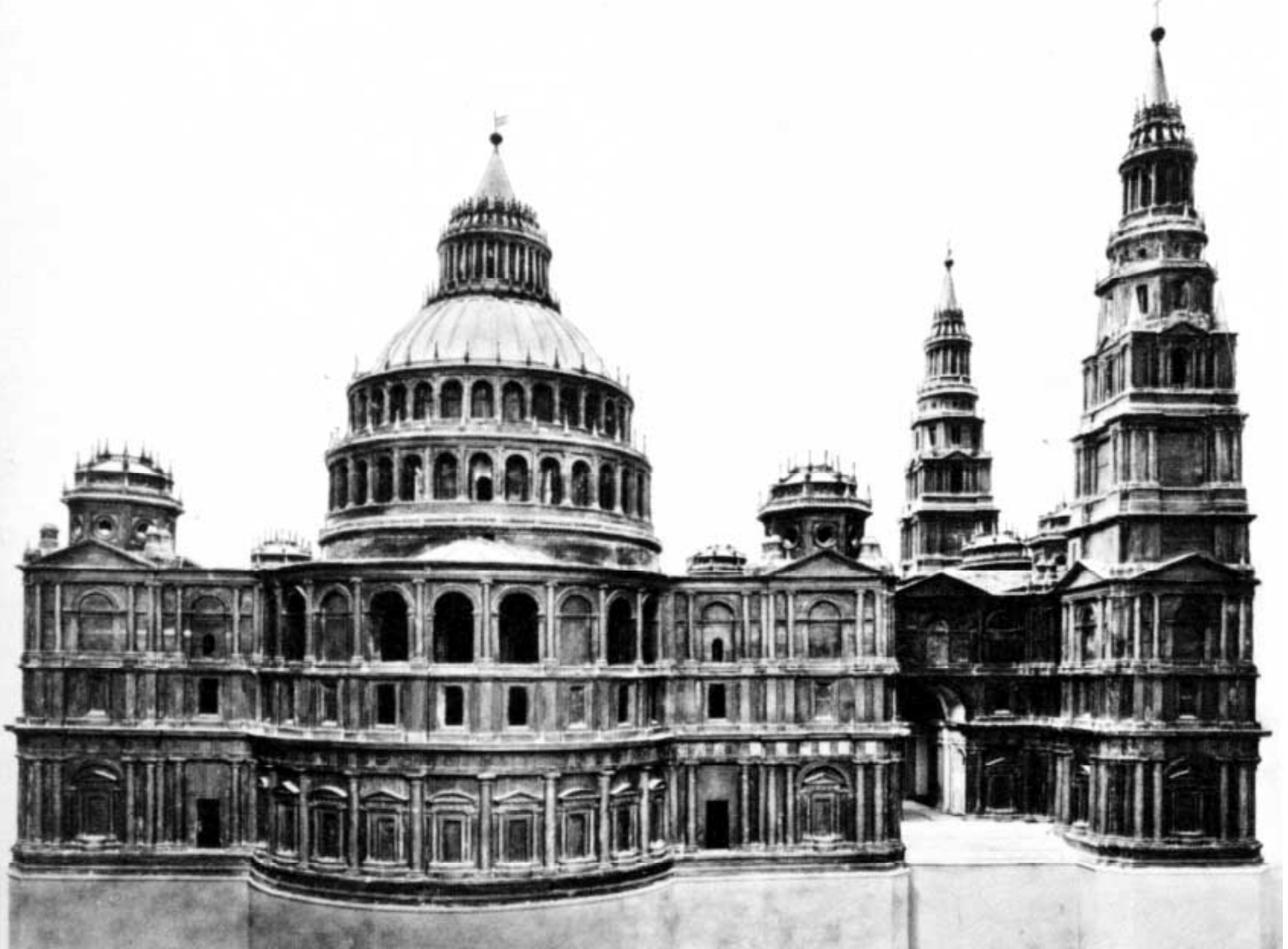

deira 84 - Modelo em maPedro Facha pra An de São

Sangallo, o Jovem. (MILLON e LAMPUGNANI, 1994, p.35)

Figura 85 - Modelo em madeira para o projeto de São Pedro. Face sul. Antonio da Sangallo, o Jovem. (MURRAY, 1972, p.163).

Embora hoje esteja a maior parte em madeira crua, originalmente o exterior também apresentava duas cores ainda que a superfície externa da Basílica em construção fosse, muito provavelmente, toda revestida de um único material, mármore travertino. Em lugares de difícil acesso, ainda se conservam resquícios dessa pintura externa.

O modelo original de Sangallo encontrava-se em uma base similar à que está atualmente, com altura de $113 \mathrm{~cm}$. Porém, no século XVIII, a base com pintura nova ou já substituindo a original, aparece com uma inscrição datada de 1704, gravada para a comemoração do restauro do modelo realizada no pontificado de Clemente IX. A altura da base permite acessar o interior do objeto através da abertura entre as metades da parede lateral do transepto norte, montadas 


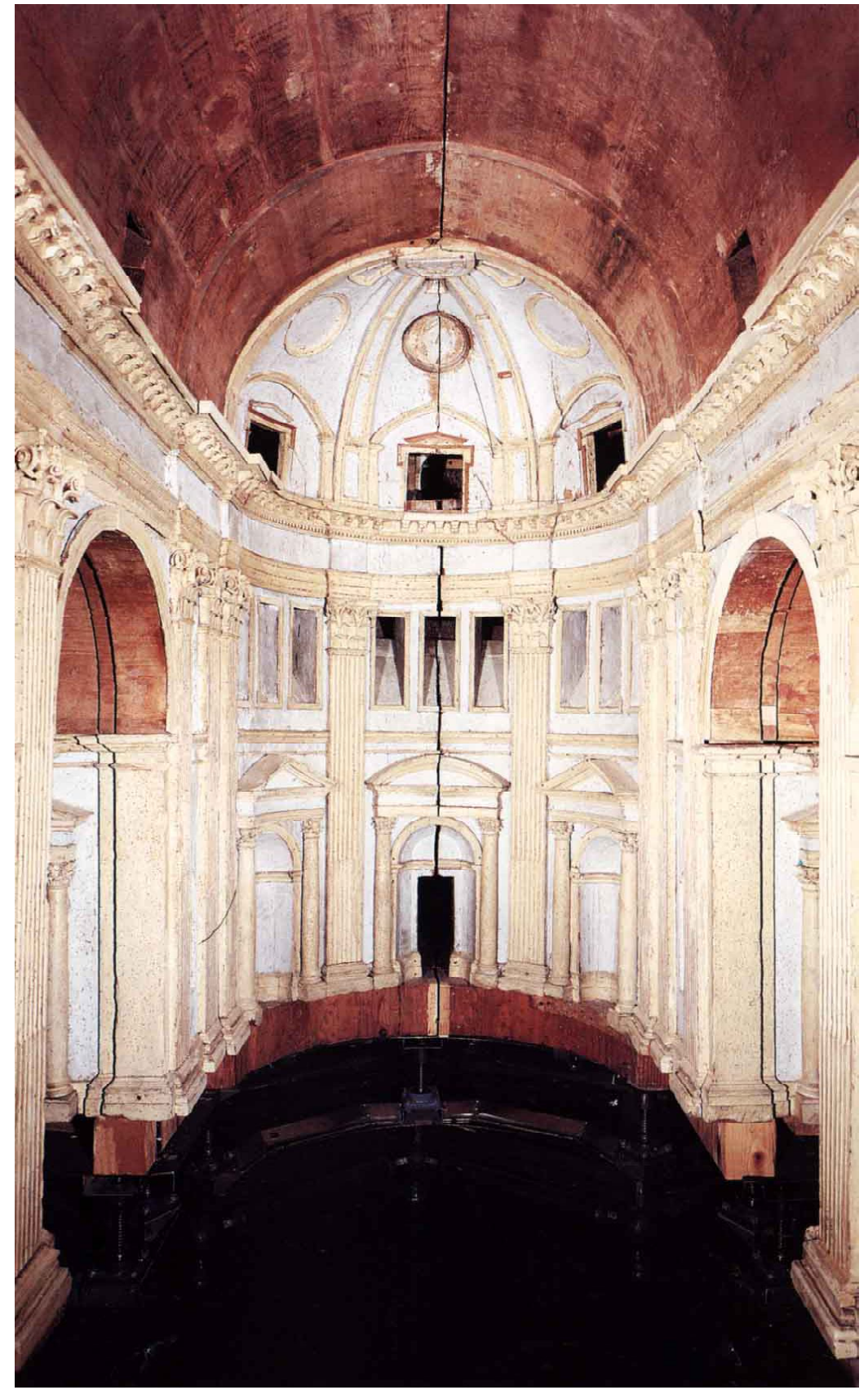

Figura 86 - Modelo em madeira para o projeto de São Pedro. Interior. Antonio da Sangallo, o Jovem. (MILLON e LAMPUGNANI, 1994, p.41)

sobre essas mesmas bases, assim como era no projeto original.

Esse modelo foi construído em escala 1:30, e em seu interior, o transepto tem $80 \mathrm{~cm}$ de largura. A altura da abóbada circular, a partir do piso da Basílica, ou seja, da base das pilastras da arcada principal, mede $155 \mathrm{~cm}$. Na construção do modelo, foram realizadas algumas distorções para assegurar a visão do observador como se estivesse dentro da Basílica construída. A abóbada central, a nave e o coro se apresentam

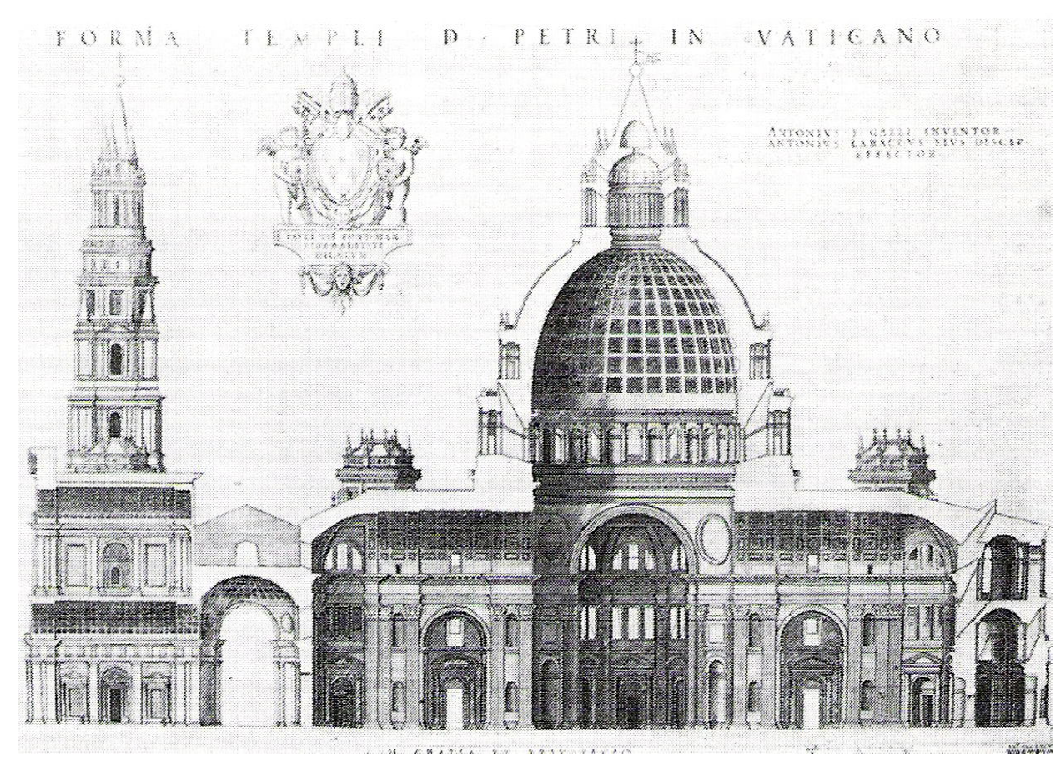

sem a elevação de sobre um pequeno anel de base, já que no interior da Basílica, seu visitante não os enxerga. Esse pequeno "anel" é um artifício utilizado na construção, para que as abóbadas não tenham alguma parte escondida pelo ressalto da cornija do entablamento da arcada principal. Toda essa composição pretendia simular o projeto, como se a Basílica já estivesse construída.

A maquete de Sangallo apresentava uma conciliação peculiar entre a planta central e a forma de basílica, isto é,

Figura 87 entre a cruz grega e a planta longitudinal da nave.

Após a morte de Sangallo em 1546, Michelangelo assumiu o cargo, alterando radicalmente as idéias para a elevação exterior e para a parte leste da basílica. Michelangelo, segundo Vasari, criticou o modelo de Sangallo, pela frustrada tentativa desse em manter o repertório formal de Bramante e de Rafael, mesmo após vinte e cinco anos de diferença.

Imediatamente após assumir o cargo, Michelangelo apresentou duas maquetes, propondo mudanças no projeto de Sangallo. Não foi muito aceito pelos trabalhadores da Fabbrica, mas com o apoio do papa, pôde seguir em frente 


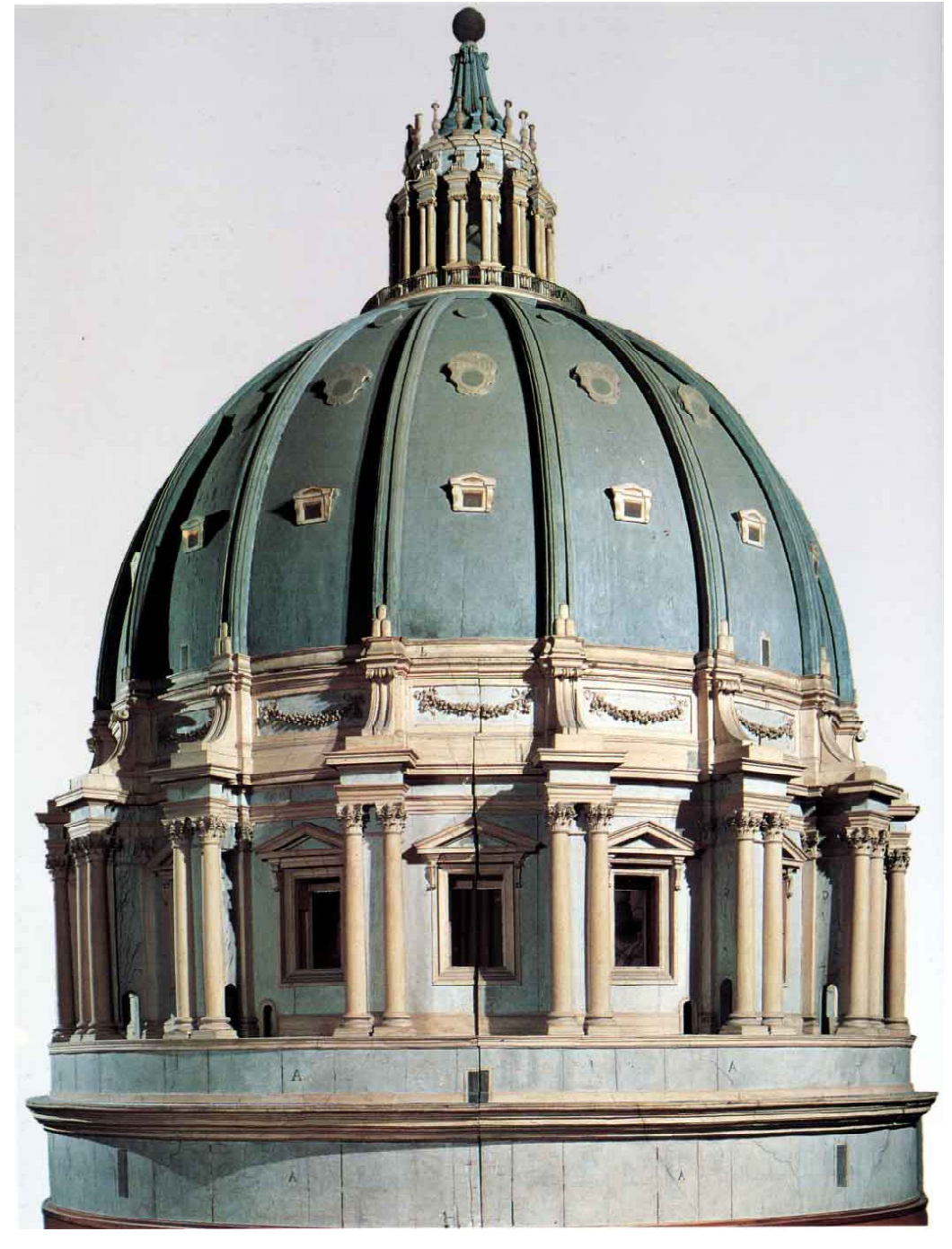

com seu "novo" projeto.

Após Antonio da Sangallo, o Jovem, Michelangelo também realizou uma série de modelos para a Basílica de São Pedro.

Michelangelo era escultor, pintor e como ressaltou Vasari, referência para toda uma geração de arquitetos. Michelangelo tratava a construção com a mesma atenção que seus desenhos. Unia prática e teoria, assim como o arquiteto humanista que Alberti pregava em seu tratado.

Os principais modelos realizados por Michelangelo para a Basílica de São Pedro foram quatro. Deles, o I Modelo era pequeno e representava a Basílica inteira. O II Modelo,
Figura 88 - Modelo em madeira da cúpula de Michelangelo para a basílica de São Pedro. Alterações de Della Porta. (MILLON LAMPUGNANI, 1994, p.44)

Figura 89 - Interior do modelo em madeira da cúpula de Michelangelo para a basílica de São Pedro. Alterações de Della Porta. (MILLON e LAMPUGNANI, 1994, p.45

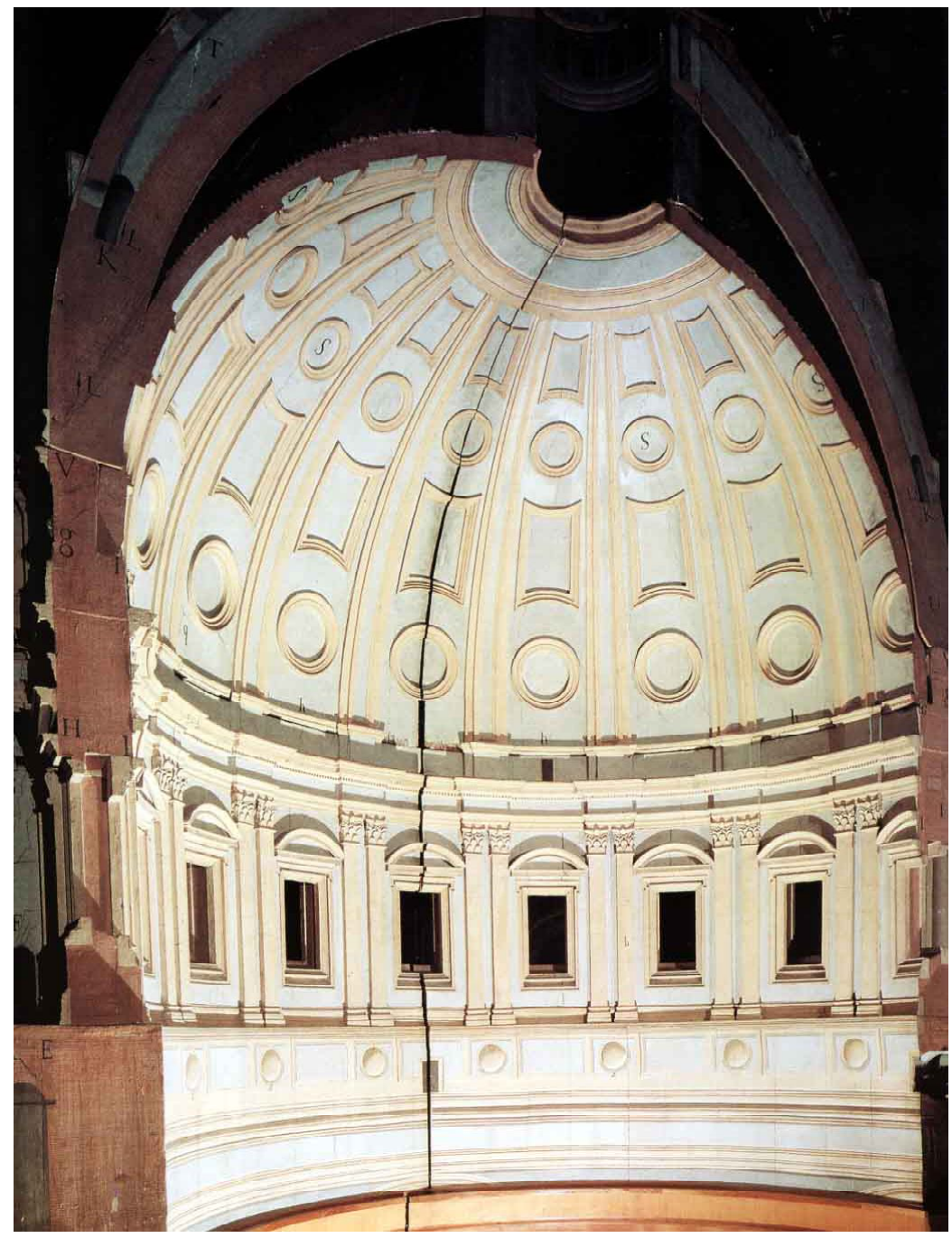

relativo a uma grande seção da Basílica, foi construído em madeira no período de 1546-1547. O III Modelo representa a cúpula principal. E o IV Modelo foi construído em escala 1:15 e teve modificações introduzidas posteriormente por Della Porta.

Ainda que a maior parte dos modelos para São Pedro fossem construídos em madeira, alguns documentos atestam que o I e o III Modelos preparados por Michelangelo fossem feitos em argila. O III Modelo ficou conhecido por causa de um pagamento feito a um trabalhador para construir e cozêlo. (FREY, pág. 81, 1916).

Na Casa Buonarroti, em uma pintura de Domenico Passignano está representada a figura de Michelangelo 
apresentando um modelo ao papa. Por aparecer representado em madeira, acredita-se que seja o II Modelo de Michelangelo.

O IV Modelo é o grande modelo arquitetônico de metade do tambor e da cúpula, realizado em madeira, em 155861, atualmente conservado no Museu do Vaticano.

Além desses quatro modelos de grande dimensão, Michelangelo, em 1549, preparou modelos menores, também em madeira, para diversos elementos arquitetônicos, como a cornija do interior da galeria transversal de São Pedro, que compreendia cinco rosáceas; uma capela, em dezembro de 1548; a abóbada do semicírculo sul e os modelos em escala natural, executados em pedra por um grupo de alpinistas em 1560 - cornija do semicírculo norte, capela do Imperador, para o entablamento saliente e os capitéis de sustentação do tambor (1561-1562).

Parece provável que durante toda a atividade de Michelangelo na Basílica tivessem sido construídos alguns outros modelos. Em uma carta sua a Vasari, Michelangelo fala da abóbada da parede em arco da galeria transversal sul de São Pedro, afirmando ter construído um modelo para cada coisa. Essa afirmação supõe que os modelos de partes da estrutura eram definitivos e deveriam servir de apoio à construção. Entre os modelos de Michelangelo para São Pedro aqui citados, sete foram supostamente utilizados na construção: o II Modelo; o modelo em pedra e madeira da cornija; o modelo da capela; o modelo em madeira para o tambor e a cúpula (IV Modelo); modelo para o entablamento; os capitéis do tambor e, considerando a carta a Vasari, o modelo definitivo para a abóbada pertencente à parede em arco do semicírculo sul.

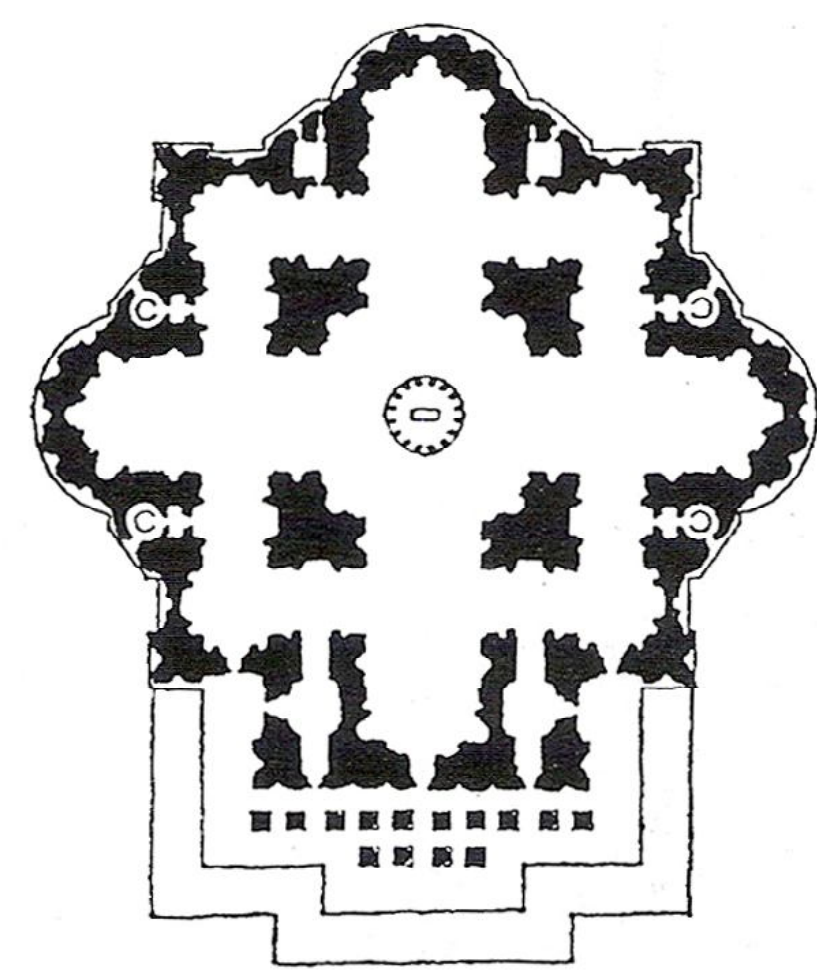

Michelangelo resolveu os problemas estruturais que haviam sido insolúveis para seus antecessores. Embora haja muitas fontes sobre seu projeto e execução durante a construção da basílica, não se sabe ao certo se suas interpretações são fiéis. Não restou nenhum modelo definitivo Figuras 90 e 91 e oficial do seu projeto final.

A partir de seu projeto, Michelangelo recuperou a idéia de planta central de Bramante, colocando toda a fachada com o mesmo tratamento. Propôs uma harmonia entre o interior e

Figura 92 o exterior, pela primeira vez, em todos os projetos.

A cúpula de São Pedro conforme está construída não corresponde aos desenhos definitivos de Michelangelo, inclusive em aspectos fundamentais. Muitos foram os estudos feitos sobre essa cúpula e principalmente sobre suas maquetes, tanto a de Michelangelo, quanto a de Antonio da Sangallo, o Jovem.

O aproveitamento da maquete de Michelangelo por 
VIIIA Coberto por Sangallo

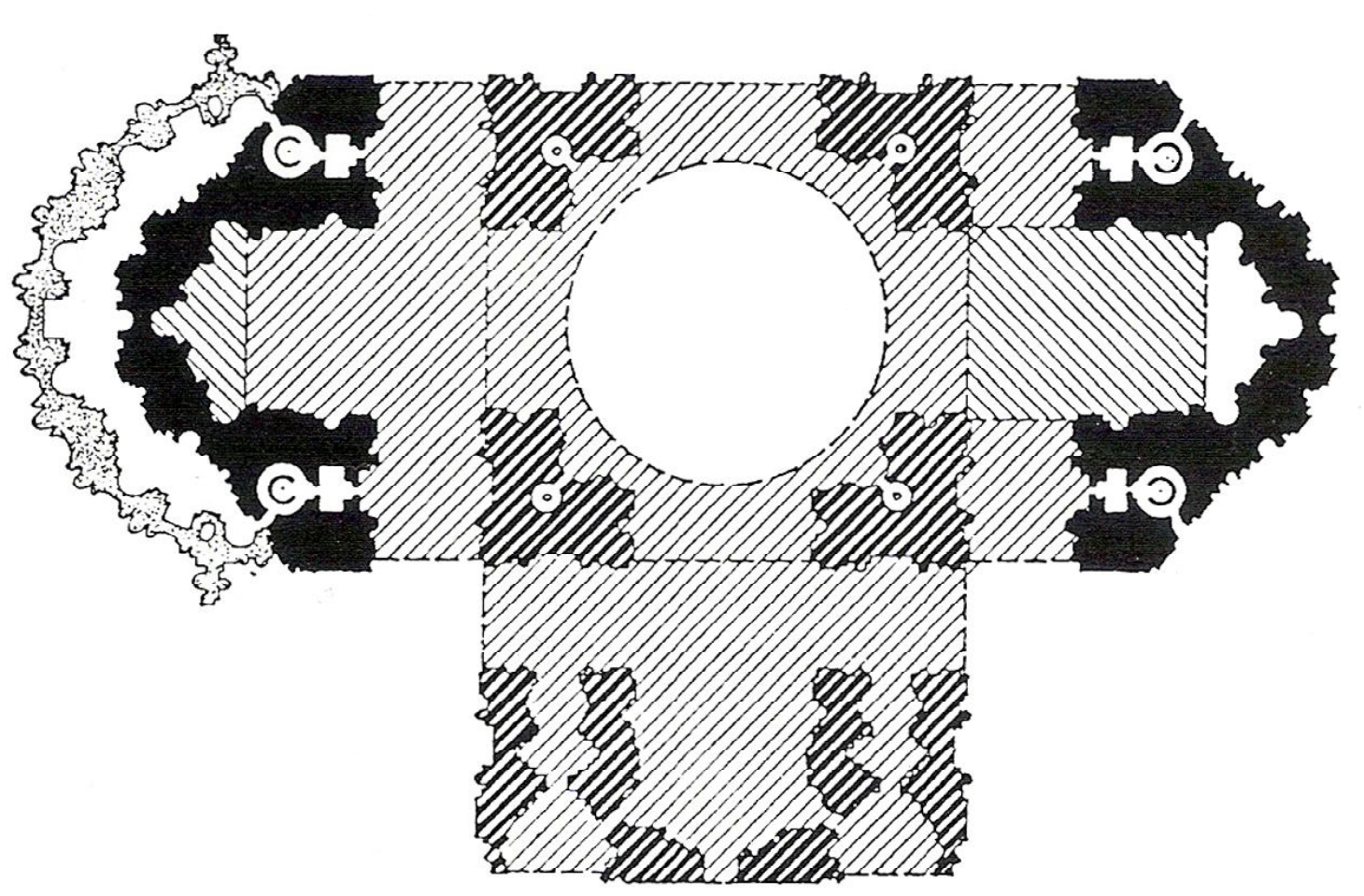

parte de Della Porta, trouxe muitas dúvidas sobre o Figura 91 - Basílica de São que seria proposto por esse e por aquele nesse mesmo objeto Pedro, construção 1506-1564. Através de alguns desenhos, informações sobre pagamentos,

com as datas específicas e com o relato de Vasari (devido ao seu livro Vidas), pôde-se, ao longo dos anos, supor quais seriam os verdadeiros projetos de Michelangelo para a cúpula da Basílica de São Pedro. Mais adiante, procuramos expor, sem muitos detalhes, quais as discussões que buscaram revelar o projeto final de Michelangelo para São Pedro.

Após a morte de Michelangelo, em 1564, Pirro Ligorio assumiu o cargo de superintendente de projeto da basílica. No entanto, foi rapidamente destituído, em 1565, por não se ater ao projeto de Michelangelo durante seu mandato. Ligorio

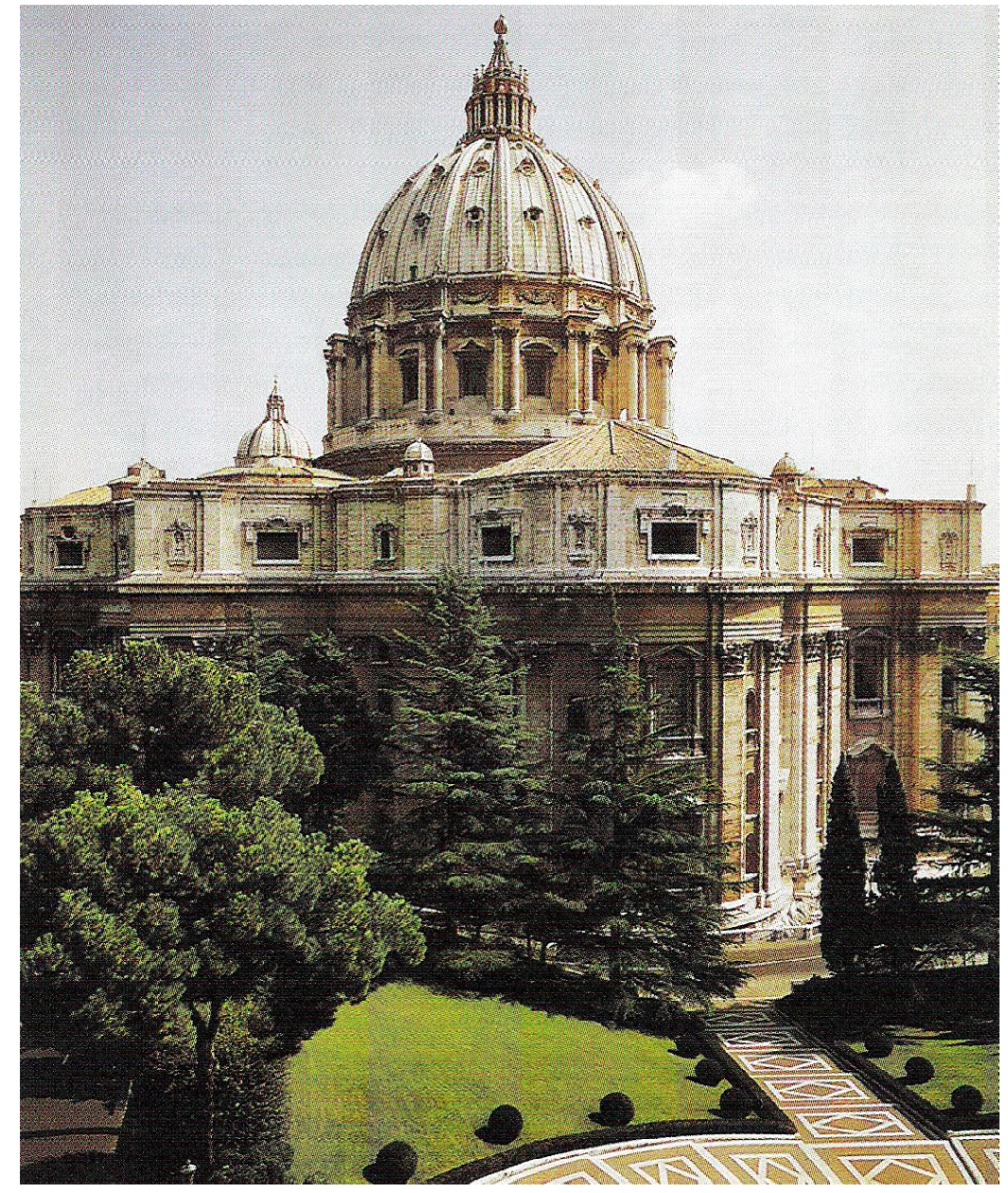

era crítico árduo das obras de Michelangelo, talvez, esse fosse o motivo para querer alterar o projeto.

Com a saída de Ligorio, Vignola (cujo nome verdadeiro era Giacomo Barozzi) passou a ser o arquiteto-chefe da construção. Vignola havia sido contratado junto com Ligorio em 1564, para ser seu assistente. E foi ele quem assumiu também outros projetos em andamento de Michelangelo. "Ao contrário de Ligorio, em cuja obra a decoração é mais importante do que a estrutura, Vignola ateve-se aos padrões e elementos tradicionais de composição arquitetônica". (LOTZ, 1998, pág. 110).

Vignola ficou encarregado da construção da basílica até 1573, ano de sua morte. Em seu lugar, assumiu Giacomo Della Porta, de se manteve no cargo de 1573 até o final da 
obra, em 1593.

Nos últimos vinte e cinco anos do século XVI, a atividade construtiva de Roma aumentou muito graças à disposição e iniciativa dos papas Gregório XIII (1572-1585) e Sixto V (1585-1590). Nesse período, entre outros projetos, deram ênfase à continuação e término da basílica de São Pedro.

Em São Pedro, Della Porta construiu a capela sepulcral de Gregório XIII e de Clemente VIII, cujos projetos, salvo uma alteração nas cúpulas, eram, provavelmente, de Vignola. Demoliu o coro de Bramante e Rosselino e construiu em seu lugar, o braço oeste do cruzeiro $^{1}$, concluindo com a cúpula principal em 1590.

A fonte de inspiração de Della Porta era Michelangelo, de onde retirou sua linguagem formal e a simplificou.

Em 1593 Della Porta finalizou a construção da basílica de São Pedro, coroando-a com o lanternim da cúpula.

Os estudos de Wittkower sobre o material compilado por Karl Frey, professor alemão que reuniu os documentos guardados nos Arquivos de São Pedro, trouxeram a tona algumas informações interessantes sobre a construção durante o tempo em que Michelangelo era o encarregado.

A primeira, já conhecida antes mesmo dessa reavaliação de Wittkower, é a prova de que em 24 de fevereiro de 1552, a cornija sobre os arcos do cruzeiro já estava terminada. Isso havia sido descoberto através de um desenho de 1553-54, anônimo.

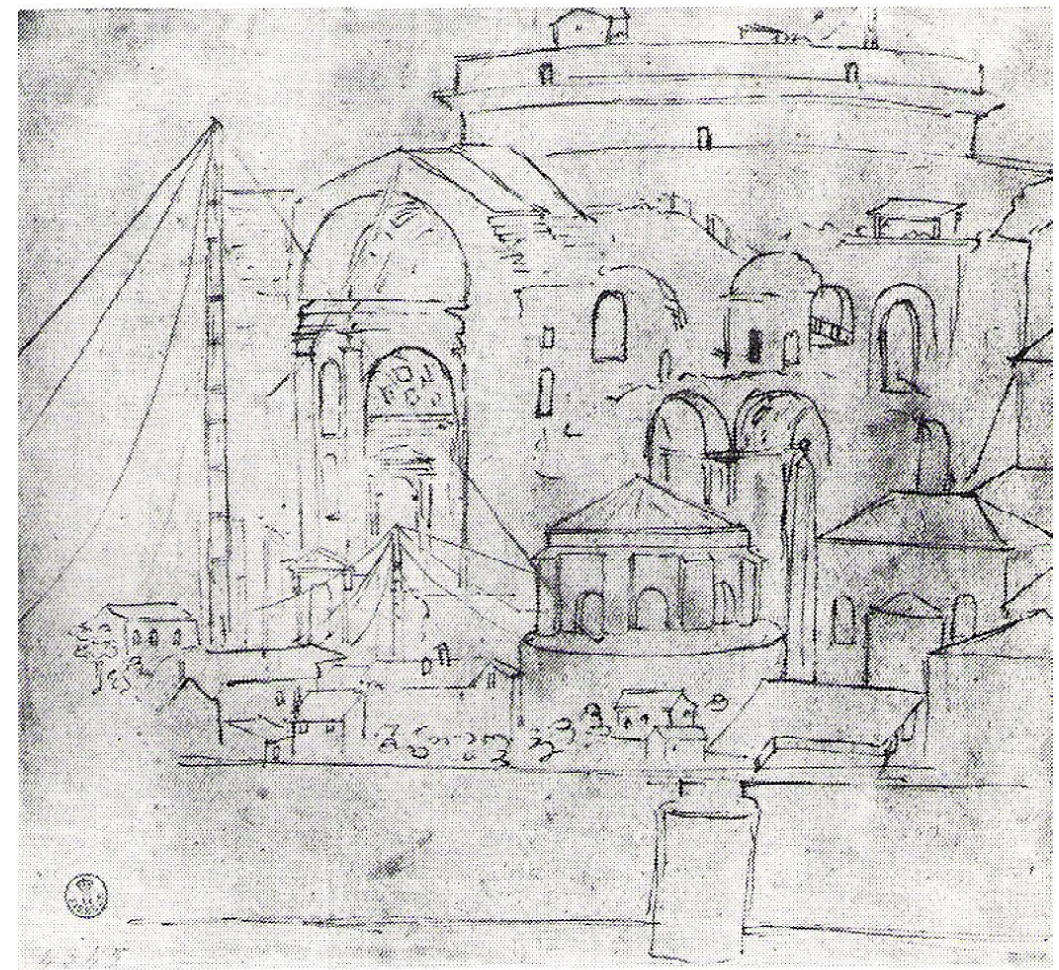

Parte da igreja entre a nave central e a capela-mor, em tras palavras, é onde se da encontro entre os "braços" da igreja, normalmente, em frente ao altar.

\section{A cúpula de} Michelangelo
Figura 93 - Desenho anônimo, mostrando o cruzeiro em construção, por volta de 15531554. (WITTKOWER, 1979, p.507)

Figuras 94 e 95 2 Parte da cúpula da igreja que corresponde ao anel que cúpula ao restante da cobertura. Em São Pedro é onde se encontram as janelas superiores, de frontão semicircular e triangular.
A segunda proposição é que em 1556 apenas seis pares de pilastras da parte interior do tambor ${ }^{2}$ e mais a metade de uma única pilastra estavam terminadas. Houve um período de recesso nessa construção, de cinco anos, que após foi retomado em 1561, concluindo no momento da morte de Michelangelo (fevereiro de 1564) os dezesseis pares completos, porém sem a cornija.

Nas duas figuras, uma identificada como do arquiteto Dosio e outra talvez de Ammanati, podem ser vistas os panos entre os pares de colunas, erguidos em 1562 aproximadamente. O primeiro é uma vista do cruzeiro voltado para o Norte, onde apenas um desses panos parece estar um pouco mais completo; na segunda imagem, vista para o Oeste, todos os panos, exceto o da esquerda, já apresentam inclusive os elementos triangulares e semicirculares sobre as janelas.

Inclusive no primeiro desenho, de Dosio, há a representação de um sistema de cordas, que muito poderiam significar o que o documento de outubro de 1562 atestava, 


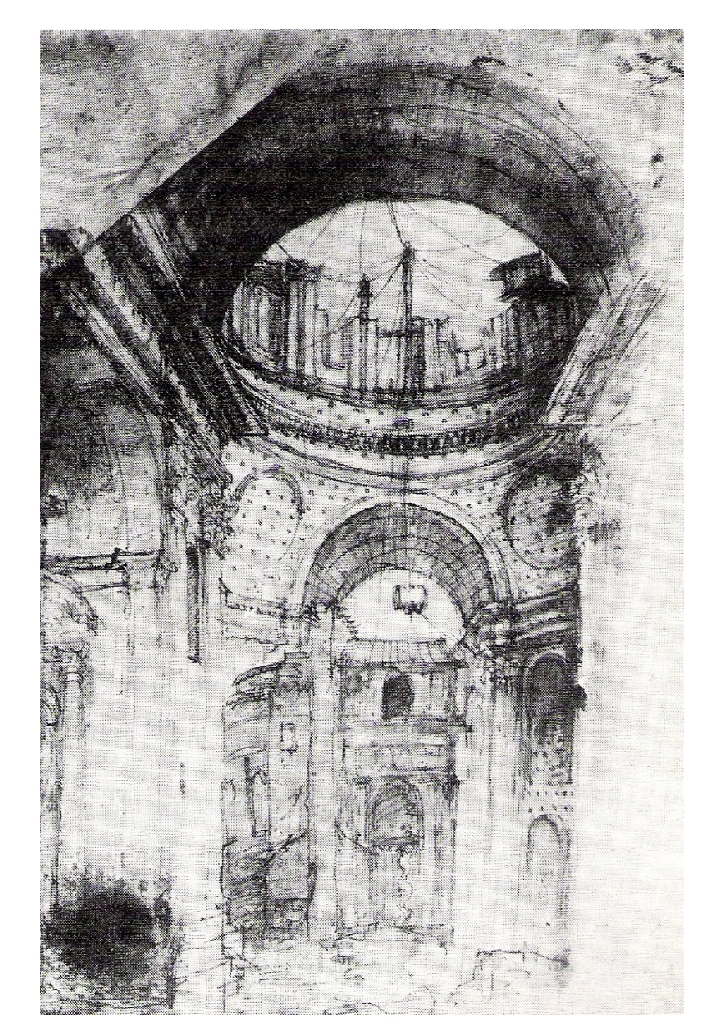

como uma forma de auxiliar a elevação de peças do fuste das colunas exteriores, que assim como as do interior, também haviam tido sua construção interrompida no mesmo período.

Há documentos que atestam o pagamento pelas cornijas das colunas duplas, entre 1565 e 1568, ou seja, no período de chefia de Ligorio e de Vignola. Além de outros, dois desenhos chamam a atenção para o início do levantamento das cornijas, principalmente a gravura em madeira, que Figuras 96 e 97 aparece mais nitidamente a cena da construção.

Já sob orientação de Giacomo Della Porta, restaram documentos de pagamentos feitos pelo ático sobre as cornijas em 1588-89, no exterior da Basílica, além de partes da arquitrave e da cornija interna, feitos em 1588, e de alguma decoração arquitetônica do interior da cúpula, realizada em 1589.
Figura 95 - Perspectiva, possivelmente de Ammanati, do cruzeiro. Vista oeste, 1562 (WITTKOWER, 1979,

de suspensão da construção da cúpula, durante cinco anos, na empreitada de Michelangelo (1556 a 1561). Esse período de recesso pode ser explicado pela biografia de Vasari, sobre Michelangelo, do qual era bom amigo. Segundo ele, ainda que a construção estivesse continuando, a passos lentos, os colaboradores e amigos de Michelangelo insistiram e acabaram por convencê-lo a realizar uma maquete da cúpula, em grande escala, para garantir que não houvesse qualquer alteração posterior, ou mesmo, alguma mudança de tendência.

Em 1557, Michelangelo iniciou sua maquete, fazendo inicialmente um pequeno objeto preliminar em terracota, a partir da qual se baseou para executar a grande, em madeira, que resiste até hoje, não totalmente igual ao que era em sua execução. Essa maquete mede cerca de 3,05 m até o "apêndice Figura 88 da cúpula interior, que pertence à maquete original" (WITTKOWER, 1979, p.509). Segundo alguns documentos, sua construção foi feita entre novembro de 1558, e novembro de 1561, embora a cúpula estivesse pronta, sem o lanternim, em 1560. 


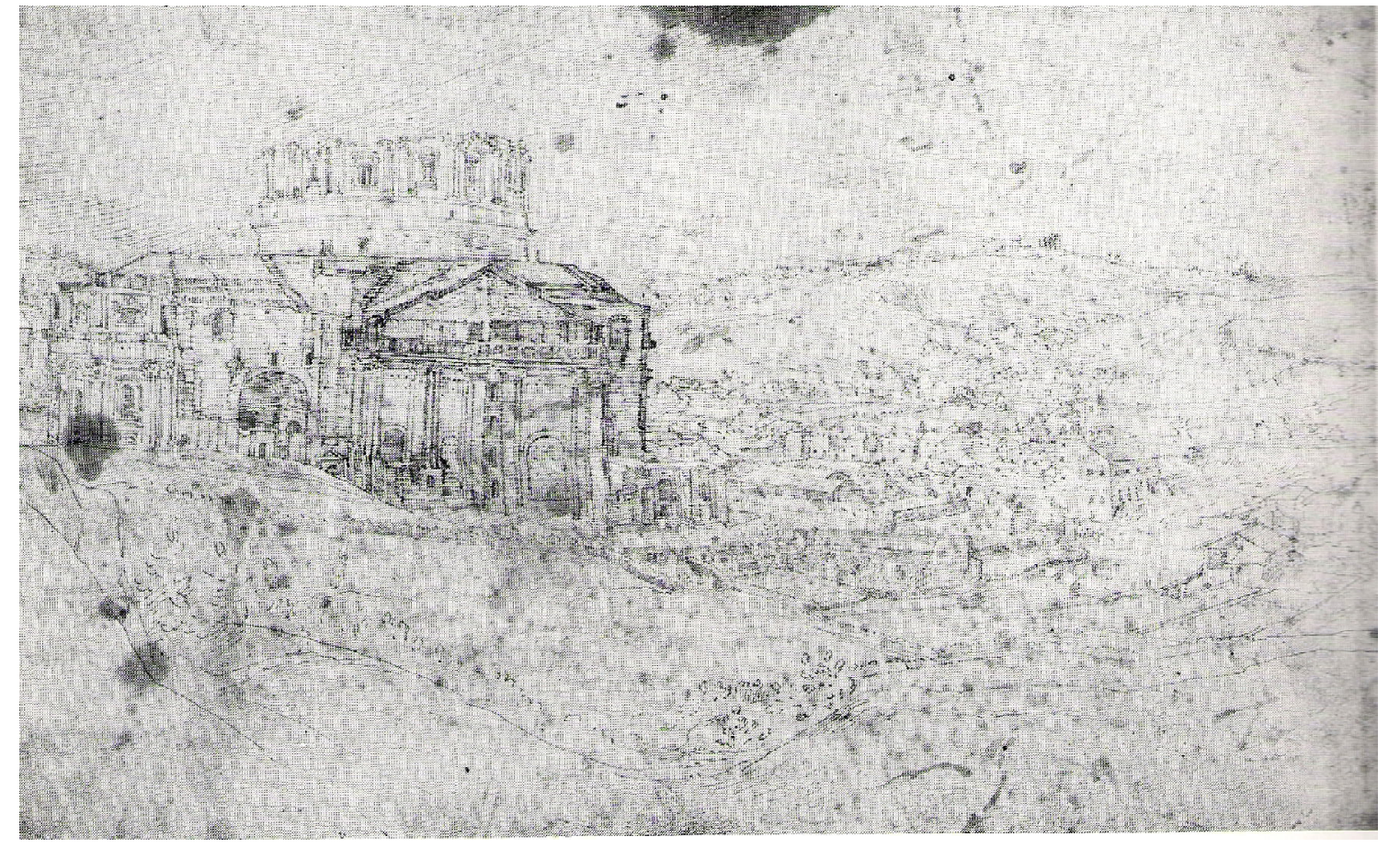

Vasari, muito amigo de Michelangelo preocupou-se em Figura 96 - Desenho anônimo mostrando São Pedro em visdescrever detalhadamente a maquete de madeira da cúpula, a ta noroeste, 1566-1567. fim de evitar possíveis alterações, incluindo-a em sua segunda edição (1568), quatro anos após a morte de Michelangelo. Inicia sua descrição dizendo que no momento em que Michelangelo iniciou a maquete de terracota, as janelas do tambor e as colunas externas estavam terminadas. No entanto, sabe-se hoje que não é verdade, pois a maquete (feita entre 1557 e 1561) apresenta frontões triangulares sobre as janelas no exterior e semicirculares no interior, diferente do que foi construído (em 1562), onde esses frontões aparecem alternados entre si, tanto no interior como no exterior da cúpula.

Dessa maneira, revela-se uma possibilidade de como Michelangelo trabalhava. Até o momento da construção do tambor, a cúpula ainda não estava totalmente resolvida, e nem quando havia a maquete, o arquiteto não foi impedido de mudar o projeto. “É significativo que Michelangelo usasse a maquete como 'referência visual', e costumasse rever novamente seus planos no último momento; dessa maneira,
Figura 97 - Detalhe de uma gravura em madeira de 1565 , mostrando já completa a parte do entablamento do tambor. (WITTKOWER, 1979, p.509).

as considerações formais e estruturais mantinham-se fortemente correlacionadas". (LOTZ, 1998, p. 101).

Embora tenha se debruçado exaustivamente também sobre o projeto do lanternim, Michelangelo deixou na maquete algumas sugestões sobre possíveis alterações em detalhes, o que reforça essa idéia do projeto em curso.

Dessa forma, a maquete se apresenta como o projeto final de Michelangelo para o interior da cúpula de São Pedro, que seguiria a mesma lógica de duas cúpulas, já de grande tradição e devidamente proposta por Brunelleschi em Florença, com certeza, uma fonte de inspiração.

Segundo Wittkower (1978), depois de longos estudos, houve uma unanimidade sobre a retirada da cúpula externa e do lanternim, a partir do ático, por parte de Della Porta. Alguns estudiosos afirmam que Porta apenas elevou a cúpula de Michelangelo, mas Wittkower não considera essa hipótese. 


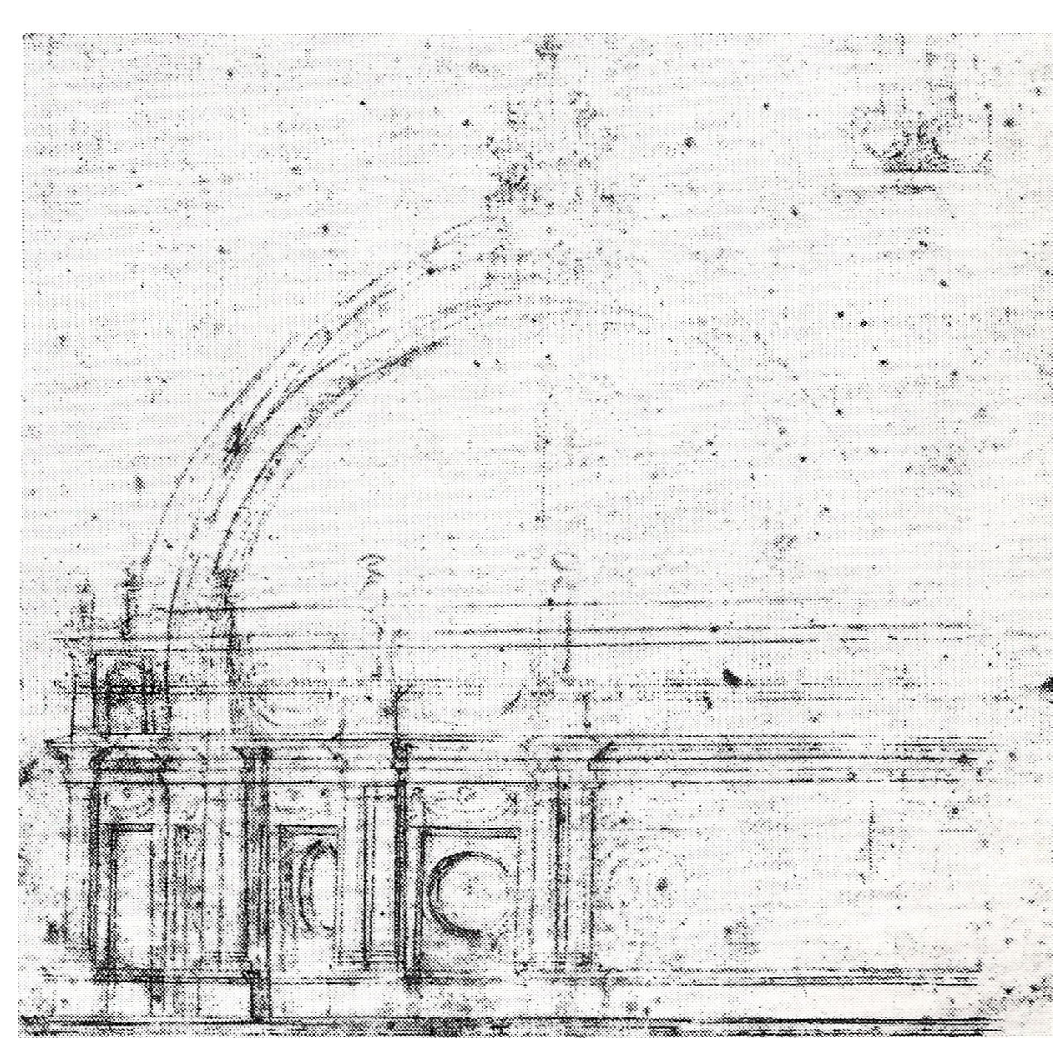

Em 1566, Dosio realizou oito estudos sobre a maquete de Michelangelo. Há também gravuras de Dupérac realizados por volta de 1568-69, sobre a catedral de São Pedro. Um desenho do próprio Michelangelo sobre estudo da cúpula também não corresponde com a cúpula existente na maquete.

Vasari descreve que a cúpula de Michelangelo era construída a partir de três centros: um para definir a forma hemisférica interior, e os outros dois para definir a forma exterior, assim como representado no diagrama de Wittkower Figura 99 (1979).

Dosio, que verificou atentamente a maquete, procurou seguir o processo construtivo utilizado por Michelangelo para realizar a cúpula dupla. Ele sabia desde o inicio, que a altura da curvatura da cúpula estava relacionada com a localização dos centros. Dosio experimentou, por meio de desenhos, realizar a cúpula com três centros, quatro centros, sete centros, para procurar a melhor correspondência com a maquete
Figura 99 - Diagrama que mostra a construção da cúpula, a partir de três centros. (WITTKOWER, 1979, p.513)

Figura 98 - Michelangelo (?) Estudo para o tambor e a cúpula. (WITTKOWER, 1979, p.511).

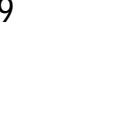




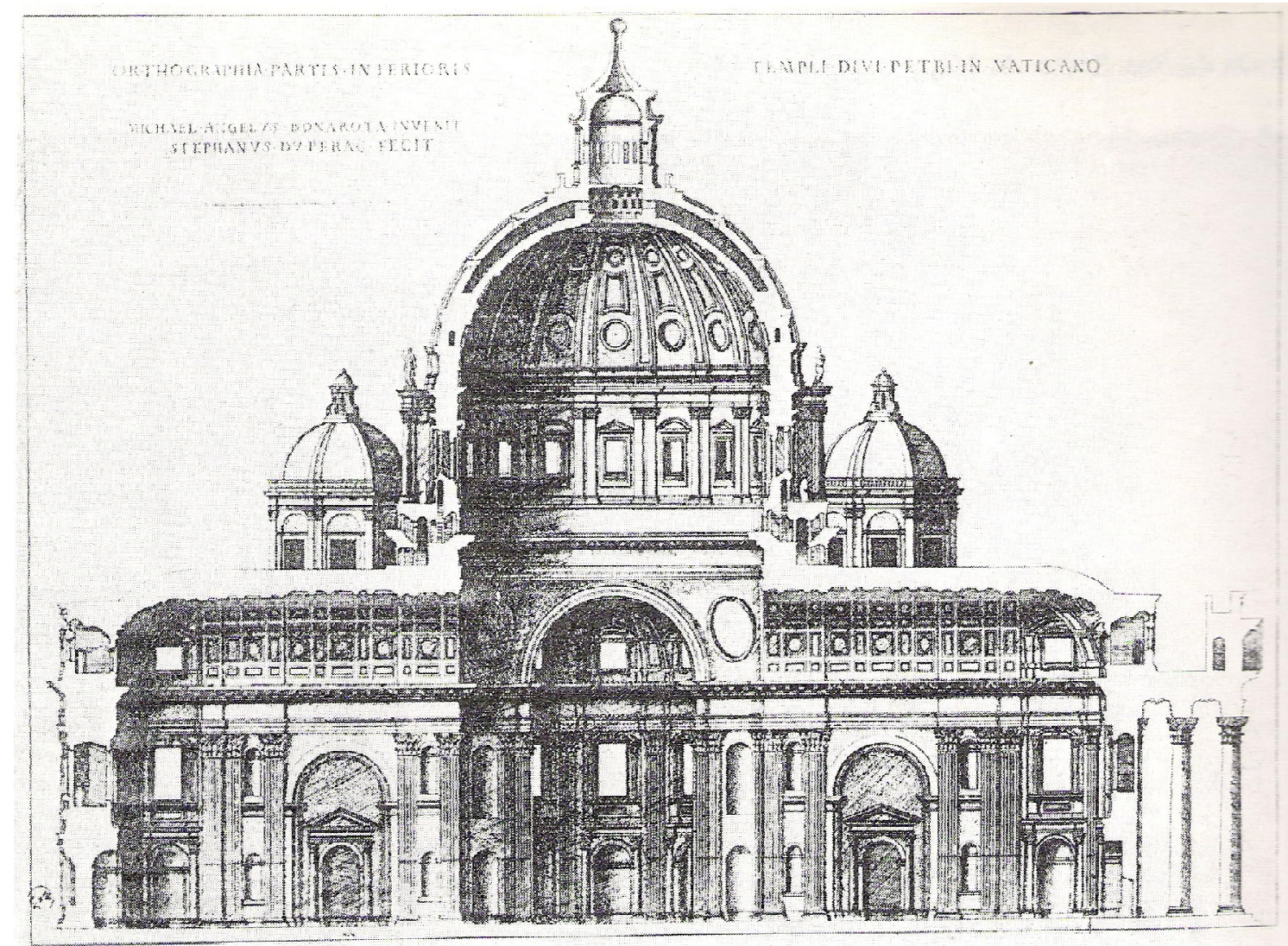

Figura 100 - S. Dupérac. Se-

considerado que o substituto de Michelangelo tenha çãolongitudinal de São Pedro, sido, por pouco tempo, Ligorio, um crítico de suas obras. baseada no projeto de Michelangelo, gravura (WITTKOWER, 1979, p.514).

Segundo Wittkower, todas as alterações no projeto de Michelangelo podem ser atribuídas a Giacomo Della Porta, o encarregado final da execução da Basílica de São Pedro (1573 a 1593). E essas mudanças podem ser comparadas ao analisar as imagens e documentos de Dupérac e Dosio. Até a moldura inferior do ático, o projeto seguiu a vontade de Michelangelo, que a partir de então foi interrompida por sua morte. Dessa forma, seguiram as alterações:

A largura do friso e do corpo das colunas salientes se reduziu e, em conseqüência, a largura dos painéis, com as grinaldas, aumentou. Permaneceu igual à altura do ático.

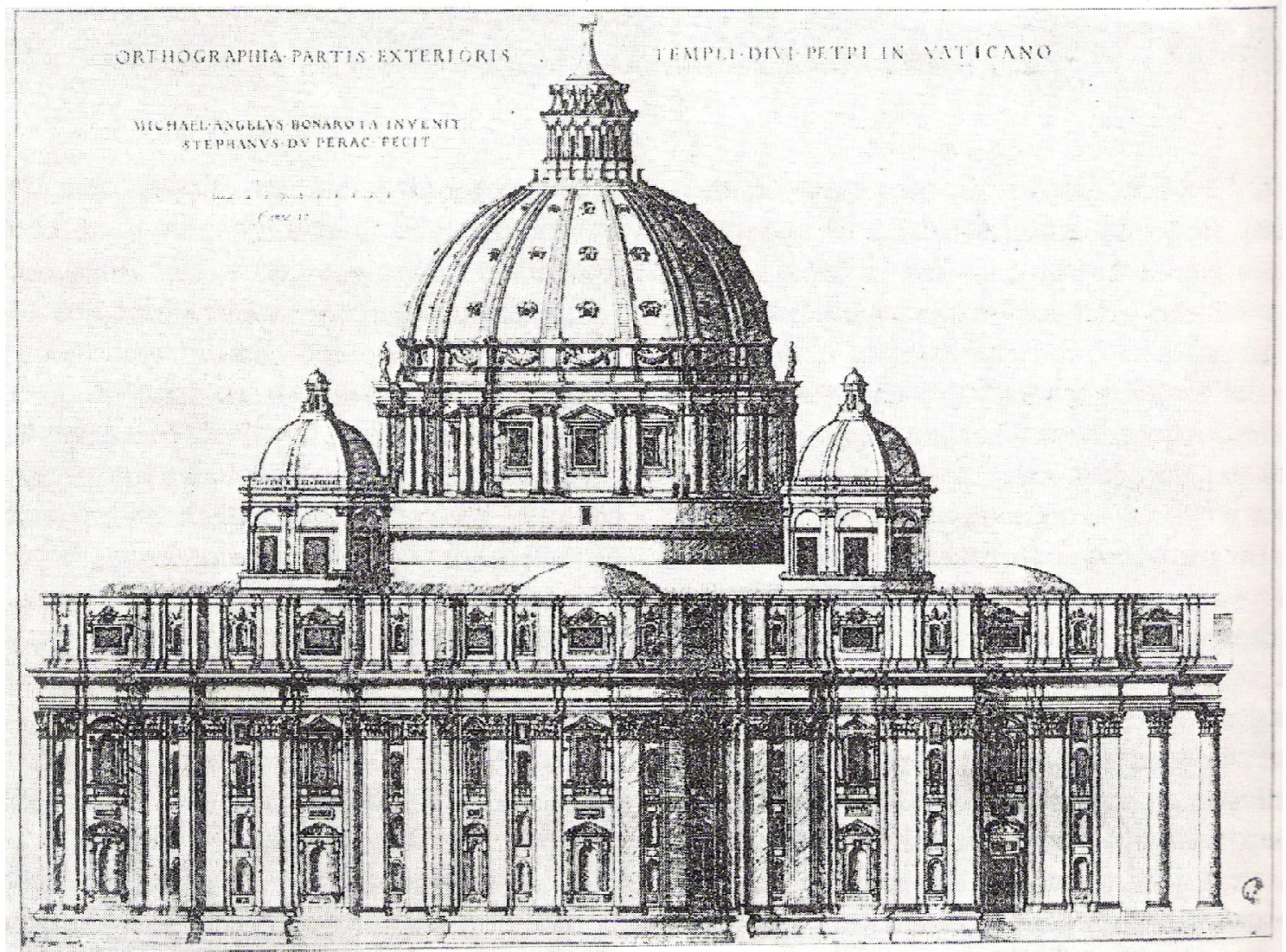

Figura 101 - S. Dupérac. Elevação exterior de São Pedro, baseada no projeto de Michelangelo, gravura. (WITTKOWER, 1979, p.514).

Mas na parte mais alta, uma rica e complexa cornija substituiu a moldura forte e simples de Michelangelo. Além disso, o ático parece mais alto porque na base da cúpula, Porta inseriu uma moldura ondulada, em forma de espiral, de mais de $91 \mathrm{~cm}$ de altura. Conseqüentemente, as nervuras não se encontram mais de forma direta com as colunas salientes do ático. Porta ocultou ainda mais o arranque das nervuras ao agregar o escudo de armas de Sexto V. Fez as nervuras mais estreitas, deu-lhes um perfil mais suave e eliminou as escadarias centrais. (WITTKOWER 1979, p.520). tanto no exterior da cúpula, quanto no interior, como por exemplo: os elementos de iluminação para o desvão da cúpula, 


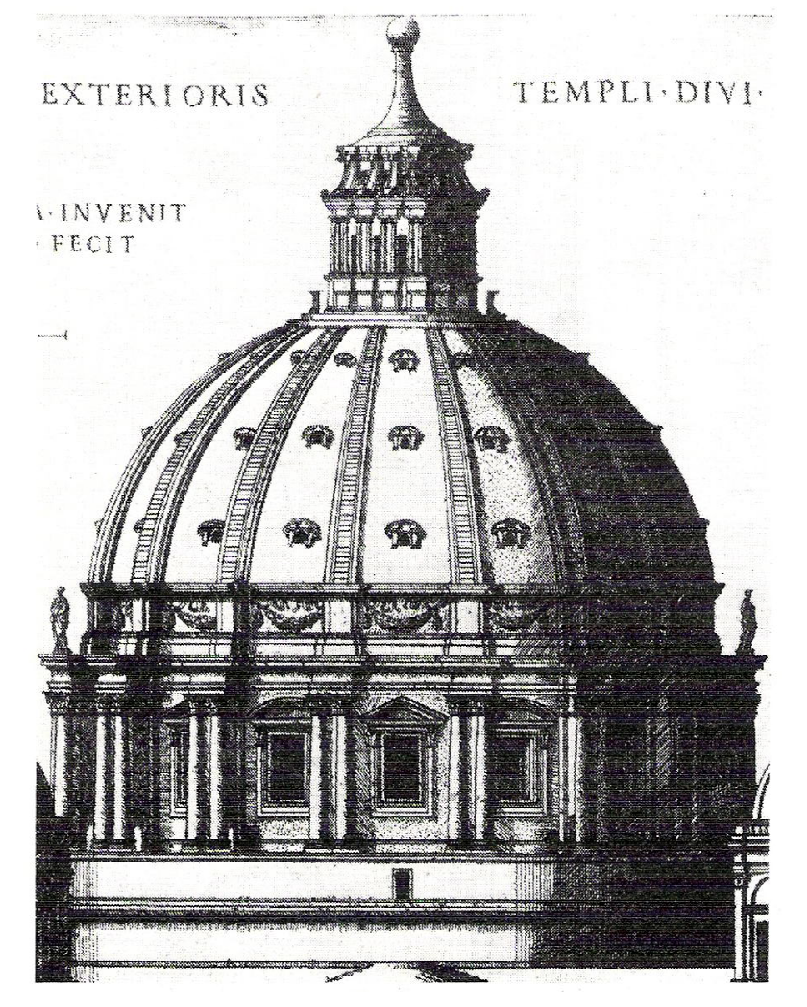

Figura 102 - S. Dupérac. Exterior da cúpula, baseado no projeto de Michelangelo, gravura. (WITTKOWER, 1979, p.520).

que Michelangelo tratava as três fileiras iguais, apenas com variação de tamanhos. Porta substituiu cada fileira por um motivo diferente, sendo o primeiro um pouco mais próximo dos de Michelangelo, o segundo, uma típica forma do século XVI e o terceiro, um círculo simples. Com isso, ao contrário do que propôs Michelangelo, Porta atraiu a atenção para os painéis entre as nervuras da cúpula. Michelangelo, em seu projeto, definia claramente a divisão entre as nervuras, os painéis e as forças dos elementos horizontais, como os anéis superiores da cúpula, para que houvesse uma hierarquia na importância de cada elemento do conjunto, o que, com certeza, as nervuras tinham seu lugar de destaque, bem definido, devido ao diferente tratamento dado a elas - "escadarias" centrais, contra um fundo de painéis lisos e neutros e um arremate de anéis superiores separado de suas estruturas. Porta, ao contrário, cria um destaque maior para os painéis, definindo uma mesma malha em relevo para as nervuras e esses painéis, além de simplificar e unir o anel superior da
Figura 103 - Letarouilly. Exterior da cúpula tal como foi construída, gravura. (WITTKOWER, 1979, p.520).

cúpula à estrutura das nervuras. Esse artifício deu uma impressão de moldura (anel superior e nervuras) para os painéis, em destaque, com suas fileiras diferentes de focos de iluminação.

No lanternim, acontece a mesma alteração no sentido da obra de Michelangelo. Enquanto esse procurava apresentar os elementos base, colunas, ático e cone (parte superior do lanternim) como elementos distintos, Porta modificou e construiu seu lanternim com formas mais suaves de transição, enriquecendo-o mais com elementos decorativos.

No interior da cúpula também há grandes alterações, inclusive que procuram seguir uma mesma linguagem Figuras 104 e 105 utilizada no exterior

Essas mudanças 


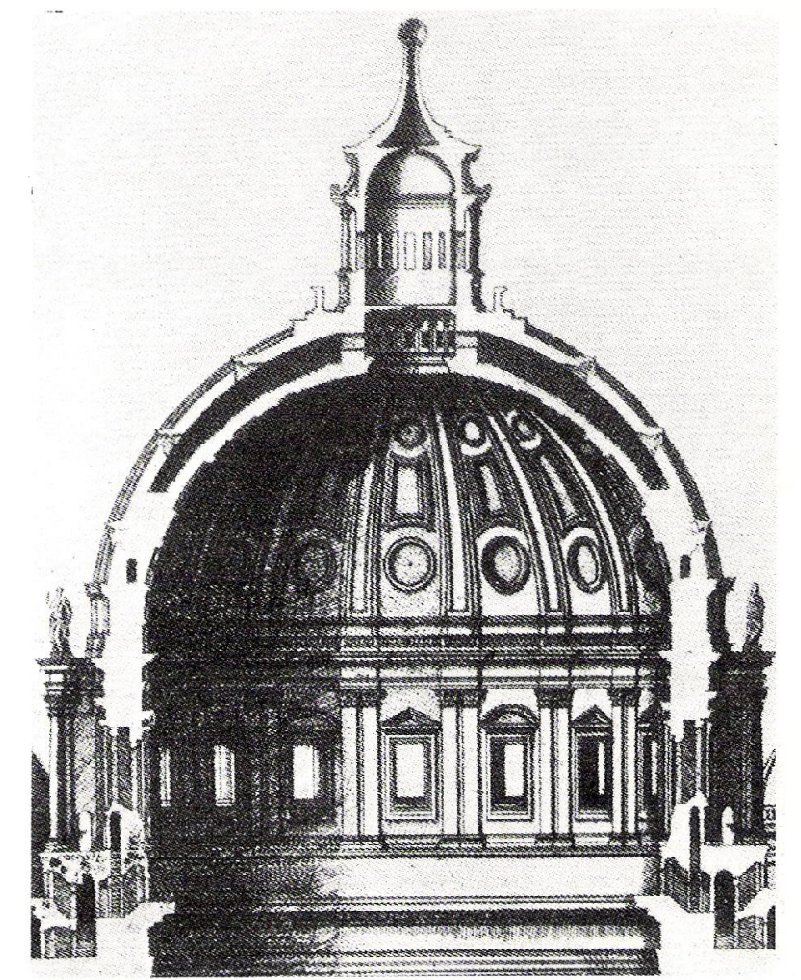

também agregou bases altas às nervuras, [que ficaram acima das de Michelangelo aproximadamente $1,80 \mathrm{~m}]$. Além disso, os arcos se elevam desde a base e produzem uma diminuição da largura das nervuras. As molduras exteriores às nervuras, junto com as molduras dos arcos, parecem pertencer a um campo neutro cuja direção de arranque, portanto, compete com a das nervuras. (WITTKOWER, 1979, p.522)

O projeto de Michelangelo para o interior da cúpula é mais simplificado em questão de detalhes decorativos, porém de maior clareza e razão em sua ornamentação. Michelangelo colocava as nervuras nascendo diretamente do ático, como uma forma de continuidade das colunas, como um direcionamento das tensões, e deixava clara sua diferenciação com os painéis, que apresentavam um ornamento de formas simples, onde o retângulo era finalizado e relacionado com dois círculos para
Figura 104 - S. Dupérac. Interior da cúpula, baseado no projeto de Michelangelo, gravura. (WITTKOWER, 1979, p.521).
Figura 105 - Letarouilly. Interior da cúpula tal como foi construída, (WITTKOWER, 1979, p.520)

amenizar o direcionamento de forças que gerava

Ainda mais importante que todas essas mudanças, foi a eliminação por Porta do lanternim interior. Esse motivo (...) er necessário a Michelangelo para evitar uma fuga das tensões dinâmicas, precisamente o que Porta procurou burlar tanto dentro como fora. Michelangelo conduzia a energia estrutural ao longo das nervuras, através das colunas do lanternim interior e dentro das dezesseis vigas (...) que convergiam para o centro. (...) Fora conseguiu resultados similares com o liso cone que pressionava o lanternim como uma pesada carga (WITTKOWER, 1979, p.522.).

Para garantir a unidade entre esses elementos, 
Michelangelo fez uma cúpula hemisférica mais baixa, pressionada, totalmente de acordo com as forças de sua obra. Porta, ao contrário, fez uma cúpula de curva mais suave, mais elevada. Enquanto a primeira solução parece mais pesada, a segunda parece conseguir "flutuar". Isso pode ser resultado da mudança de proporção entre uma e outra solução: a de Michelangelo, a cúpula está em uma relação de 5:4 com o lanternim, já a de Porta, resulta em 3:2.

Enquanto o que interessava a Michelangelo era garantir a força dinâmica que se elevaria pelos pares de colunas idênticas do corpo da igreja, passaria por outros pares de colunas no tambor, seguiria pelas nervuras, alcançaria o topo através das colunas do lanternim e se encerraria no pesado cone; para Giacomo Della Porta, a unidade estava em gerar um desenho mais conciliador; o que se acredita ter sido discutido e aceito pela comissão de eclesiásticos que coordenavam a construção.

Embora Della Porta tenha feito alterações significativas mudanças no projeto de Michelangelo para a cúpula, pode se dizer que, sua intenção nunca foi a de desprezar a idéia principal daquele grande mestre. 
Através do estudo apresentado, pode-se chegar a algumas conclusões, que naturalmente parecem óbvias, mas que, ao mesmo tempo, reforçam ainda mais a importância que a maquete adquiriu na profissão do arquiteto.

As discussões que permearam o Renascimento somente chegaram aos dias atuais, devido ao anseio do homem que, impregnado de uma autoconfiança própria do Humanismo, pretendia anunciar suas descobertas para serem propagadas. Muitas dessas discussões, embora não tenham aparecido em forma de teorias, com explicações matemáticas, geométricas, ou até esquemáticas, tiveram sua repercussão nas atividades artísticas da época.

Os relatos sobre a vida dos artistas, em forma de biografia, muito contribuíram para a documentação desses princípios, que até muito tempo, seguiram como universais. A história da arte, contada a partir desses textos e de tratados, pôde traduzir hoje, o que há muito tempo já era realizado, como o desenvolvimento dos tipos de desenhos, e de maquetes, para a atividade arquitetônica.

Todas as instâncias de desenhos relacionados à arquitetura, bem como o modelo tridimensional, têm sua história e apresentação intimamente ligada ao desenvolvimento das teorias estéticas da arte. A cada teoria explicitada, pode-se encontrar no desenho e no modelo o seu reflexo. Por exemplo, buscavam-se proporções nas artes figurativas, na escultura, e na arquitetura, independente do meio de expressão utilizado - desenho "técnico", croquis, perspectiva ou maquete.

A perspectiva, por exemplo, deveria apresentar toda a 
capacidade da relação métrica ou da proporção existente entre os corpos tridimensionais no espaço, para ser devidamente representada no plano bidimensional. Ao pensar sobre isso, é curioso o que se pretendia, ou melhor, o que ainda se pretende com a perspectiva: cristalizar por um momento o movimento do olhar, próprio dos acontecimentos vivenciados no espaço tridimensional, através de uma representação bidimensional, ou seja, plana. É por essa razão que a perspectiva, em muitos casos, pode ser denominada como modelo gráfico, ou seja, maquete gráfica. Esse modelo gráfico confunde-se principalmente nos dias de hoje, com os modelos virtuais, que, necessariamente vêm representados em uma tela de computador, a qual atua aos olhos humanos, como uma janela ou um quadro.

Assim como na história do desenho, pode-se também arriscar uma história do modelo tridimensional em arquitetura.

Pode-se dizer que o período mais significativo na história do modelo tridimensional também foi o Renascimento (assim como o desenho), que o teorizou e lançou suas bases na prática de arquitetura. A partir do estabelecimento de suas regras, acredita-se que o modelo começou a passar por momentos de desaparição, e retorno, na arquitetura.

Pensar em uma continuidade para a história do modelo, seria pensar em arquitetura moderna, com o grande acontecimento da revolução industrial; e em arquitetura contemporânea, com outro grande acontecimento, a revolução digital.

Esses dois fatos trouxeram grandes mudanças no desenho de arquitetura e, conseqüentemente, na conceituação do espaço arquitetônico. Portanto, acredita-se que o modelo tridimensional também tenha sofrido suas conseqüências.

Pode-se adiantar que poucos são os documentos

Propostas Futuras diretamente referentes à prática do modelo na arquitetura moderna. Há registros de atividades com modelos tridimensionais em alguns textos sobre arquitetos modernos; alguns outros textos sobre programas de disciplinas de escolas de arquitetura, que tratam do modelo como um ensinamento do pensamento tridimensional; e ainda outros que tratam a maquete como protótipos, objetos próprios das novas técnicas e tecnologias modernas, para ensaios experimentais sobre construção: estrutura, iluminação, ventilação e acústica.

Ainda que se saiba que a arquitetura moderna não tenha abandonado completamente o modelo, supõe-se que seu "desaparecimento" esteja ligado ao desenvolvimento completo do sistema de representação gráfica, no qual a axonometria e as perspectivas de um ou dois pontos de fuga, passaram a cumprir o papel da maquete, de forma mais rápida, na apresentação dos projetos de arquitetura. Ou talvez, a nova linguagem da arquitetura moderna tivesse o uso de perspectivas como seu elemento preferencial.

Da mesma forma que a Arquitetura Moderna respondia ao novo programa gerado pela máquina, a arquitetura contemporânea (Pós-Moderna, Pós-Industrial) se renovou frente à informática.

Com a introdução da informática no trabalho de arquitetura, muitos profissionais passaram a utilizar os recursos computacionais apenas para execução de projetos 
executivos, fazendo do computador um instrumento auxiliar na representação bidimensional. Porém, o desenvolvimento de novos softwares, com possibilidade de construção diretamente através de objetos tridimensionais, trouxeram para o arquiteto a capacidade de conceber o projeto arquitetônico através da maquete virtual, o que tornou muito mais rápido e eficiente o processo projetual, embora, nem todos os arquitetos (ainda ou talvez nunca) apresentem essa forma de projetar.

Com o advento da informática houve um retorno à discussão que envolve o modelo, agora virtual, o qual possibilitou a aparecimento de novas arquiteturas que não conseguem se resolver apenas com desenhos técnicos e maquetes físicas.

Quanto à sua inovação tecnológica, o CAD (ComputerAided Design) adquiriu uma importância comparável ao da introdução do papel na representação gráfica. O sistema CAD facilitou a representação em duas e três dimensões, permitindo a imediata visualização de formas espaciais previamente definidas.

Novas e mais recentes aplicações, facilitadas pelo software Form Z e Alias - conhecido pelo público graças à ilustração do trabalho de Frank Gehry, feita sobre o Museu Guggenheim de Bilbao - consentiram um melhoramento decisivo da capacidade de idealizar complexas elaborações de planos, lajes curvas e onduladas. Neste caso, o computador não só acelera os processos de projeto, até então desenvolvidos manualmente, mas aumenta as potencialidades em relação à prancheta, com extraordinária possibilidade de ampliação das formas arquitetônicas.
Além de permitir a geração do modelo virtual, o computador, junto com os novos softwares para a construção de um modo geral, possibilitou a extração de imagens em perspectivas do modelo gerado, tanto no nível do olhar de um observador, como se esse estivesse vendo o modelo físico, ou seja, de cima. São infinitas as possibilidades de trabalhar e visualizar o modelo com a nova tecnologia informatizada. A geração de modelo se funda com a construção gráfica convencional em uma só ação. Nesse momento, a relação desenho-modelo torna-se até mais estreita e interligada que no Renascimento. Agora, não há mais a dúvida em saber qual a melhor forma de visualizar um projeto: perspectiva ou modelo, o conjunto de dados que são necessários para o projeto informatizado permite a extração da melhor forma de representação para o arquiteto, basta escolhê-la.

Apesar de possibilitar novas experiências com a representação de arquitetura, e até novas maneiras de conceber o processo de projeto, o arquiteto continua tendo a mesma importância e característica dos grandes arquitetos da Antiguidade. A arquitetura começa no pensamento, e esse tem um único objetivo, atender as necessidades da sua época da melhor forma possível, independente do período ao qual pertença

Não importa como venham representados, uma planta, uma elevação e um modelo gráfico (como se refere Migliari às perspectivas), um modelo físico ou uma maquete virtual, todos são modelos de arquitetura, e todos têm características em comum. 
que suscitam ao observador: são imagens capazes de evocar a forma e as qualidades, não só formais, do objeto que representam; em segundo lugar têm em comum os elementos que os compõem: linhas, superfícies, sólidos; em terceiro lugar permitem intervir sobre o objeto representado com operações como: a medida de grandezas lineares, de superfícies ou de volume; a geração de superfícies e de suas composições; o corte a alteração, a deformação dos sólidos. (MIGLIARI, 2003, p.17).

Acreditamos ter representado aqui as premissas que tornaram um objeto de representação em escala - o modelo tridimensional, em um elemento de grande significação e importância ao arquiteto e à arquitetura.

Cabe-nos aqui, deixar uma lacuna nessa história do modelo - sua suposta ausência na arquitetura moderna e seus novos conceitos e ferramentas na arquitetura contemporânea, que acreditamos ser assunto de uma bela e importante pesquisa futura. 
LIVROS

ACKERMAN, J. S. Architectural Practice in the Italian Renaissance, Journal of the Society of Architectural Historians, XIII, pp. 3-11, 1954

ACKERMAN, J. S. The Architecture of Michelangelo, 2 vols.: I text; II catalog, London, 1961

ACKERMAN, J.S. Architettura e disegno: La rappresentazione da Vitruvio a Gehry. Tradução para língua italiana de Lara Bianciardi, Nicoletta Marconi e Margherita Zizi. Título original: Origins, Imitation, Conventions, Electa, Milano, 2003.

ALBERTI, L.B. L'Architettura (De Re Aedificatoria). Texto latino, tradução italiana de Giovanni Orlandi, introdução e notas: Paolo Portoghesi 2 vols., Edizioni Di Polifilo, Milão 1966

ARGAN, G. C. El concepto del espacio arquitectonico desde el Barroco a nuestros dias. Nueva Vision, Buenos Aires, 1984

ARGAN, G. C. Renacimiento y barroco: de Giotto a Leonardo da Vinci. Ed. Akal, Madrid, 1987.

ARGAN, G. C. Clássico Anticlássico: o Renascimento de Brunelleschi a Bruegel. Ed. Companhia das Letras, São Paulo, 1999

Arquitectura de Frank Gehry. Gustavo Gili, Barcelona, 1988.

ARTIGAS, J. B. Aula inaugural pronunciada na FAUUSP, em 1 de março de 1967.

BAKER, G. H. Le Corbusier: Analisis de la forma, Ed. Gustavo Gili, Barcelona, 1994.

BANHAM, R. Teoria y diseno arquitectonico en la era de la maquina. Nueva Vision, Buenos Aires, 1965.

BARBARO, D. Di Marco Vitruvio Pollione i dieci libri commentati. Venecia, 1556.

BAZIN, G. História da história da arte. Ed. Martins Fontes, São Paulo, 1989.

BENEVOLO, L. As Origens da Urbanística moderna. 2ª̀ ed. Lisboa, Editorial Presença, 1987. 
BERTOL, D. Vizualizing with CAD: an AutoCAD exploration of geommetric and architectural forms. Telos, Nova York, 1994.

BLUNT, A. Artistic Theory in Italy: 1450-1600. Londres, 1935.

BOESIGER, W. Le Corbusier: Oeuvre complète 1946-1952. Zurique, Editions Girsberger, 1953. BOESIGER, W.; GIRSBERGER, H. Le Corbusier 1910-65. Barcelona, Editorial Gustavo Gili, 1971.

BRAYDA, C. Stili di architettura e dizionario dei termini usuali. Torino, Chiantore, 1947.

BROWN, K. Computers in the professional practice of design. McGraw-Hill, New York, London, 1995.

BROWN, K.; CURTIS, C. Computers In the Professional Practice of Design. McGraw-Hill, New York, 1995.

BURKE, A. E. (1909). Architectural and building trades dictionary /[by] Arthur E. Burke, J. Ralph Dalzell [and] Gilbert Townsend. Edited by Pearl Jenison, Chicago, American Technical Society, 1950.

CASTILHOS, J. R. O modelo tridimensional no ensino da arquitetura, 1959.

CEVESE, R. Piccolo Dizionario Dei Termini Di Storia Dell' Arte, Milano, Garzanti, 1985.

CHING, F. D. K. Diccionario visual de arquitectura, Barcelona, Gili, 1997.

CIUCCI, G.; DAL CO, F. Architettura italiana del ‘900. Milão: Electa, 1990.

COWAN, H. J. Dictionary of architectural science, London, Applied Science Publishers, 1973.

COWAN, H. J. Models in architecture, Elsevier Publication Co., Amsterdam, New York (etc.), 1968.

CURTIS, W. J. R. La Arquitectura Moderna desde 1900. Madri: Hermann Blume, 1986.

DAGOSTINO, F. R. Desenho arquitetônico contemporâneo. Hemus, São Paulo, 1980.

Enciclopedia GG de la architectura del siglo xx, Barcelona, Gili, 1989.

FILARETE, (Antonio Averlino). Trattato di Architettura, 2 vols., ed. A. M. Finoli e L. Grassi,
Milão, 1972.

FLEMING, J. (1919). The Penguin dictionary of architecture /[by] John Fleming, Hugh Honour [and] Nikolaus Pevsner; drawings by David Etherton, 2nd ed., Harmondsworth, 1972

FRAMPTON, K. História Crítica da Arquitetura Moderna; tradução Jefferson Luiz Camargo. São Paulo, Martins Fontes, 1997.

GARDINER, S. Le Corbusier; tradução de Gilberto B. de Oliveira e Jamir Martins; revisão de Paulo J. V. Bruna. São Paulo, Cultrix, Ed. da Universidade de São Paulo, 1977.

GNONE, T. Dizionario architettonico illustrato: con aggiunta della terminologia riguardante, la pintura, la scultura, la decorazione e le arti minori, Torino, Societa Editrice Internazionale, 1968.

GOLDTHWAITE, R. The building of Renaissance Florence: An Economic and Social History. London, The Johns Hopkins University Press Ltda., 1980.

GROPIUS, W. Bauhaus: novarquitetura. Tradução de J. Guinsburg e Ingrid Dormien., Perspectiva, São Paulo, 1977.

GYMPEL, J. The Story of Architecture: from Antiquity to the Present, Könemann, Cambridge, 1996

HALSE, A. O. Architectural rendering: the techniques of modern presentation. Dodge, New York, 1960.

HARRIS, J. (1931). Illustrated glossary of architecture, 850-1830 / [by] John Harris \& Jill Lever, London, Faber, 1966.

HATJE, G. Diccionário ilustrado de la arquitectura contemporánea /Dirigido por Gerd Hatje /revisada y puesta al día por Laureano Sabater, Barcelona, G. Gili, [1970?].

HATJE, G. Encyclopaedia of modern architecture, edited by Wolfgang Pehnt. Contributors, Kyösti Alander [and others], London, Thames and Hudson, 1963.

HATJE, G. The Thames and Hudson encyclopaedia of 20th century architecture Expanded and completely rev. ed. /general editor Vittorio Magnago Lampugnani, [translated from the German Lexikon der Architektur des 20. Jahrhunderts and edited by Barry Bergdoll], London, Thames and Hudson, c1986. 
HENDRICK, T. W. The Modern architectural model. With a foreword by Hugh Casson, Architectural Press, London, 1957.

HEYDENREICH, L. H. Arquitetura na Itália: 1400-1500. Cosac \& Naify Ed., São Paulo, 1998.

JACOBS, S. P. The CAD Design Studio: 3D Modelling as a fundamental design skill. McGrawHill, New York, 1991.

JANKE, R. Architectural Models. Translated by James Palmes from the German, Thames \& Hudson, London, 1968.

JENCKS, C. El lenguaje de la arquitectura Posmoderna. Gustavo Gili, Barcelona, 1984.

JOHANNES, I. Design and form; the basic course at the Bauhaus.Translated by John Maass, Reinhold Pub. Corp., New York, 1964.

KOSTOF, S. The Architect, Oxford University Press, New York, 1977.

KRUFT, H. W. A History of Architecture Theory from Viruvius to the Present, Londres e Princeton, 1994.

LE CORBUSIER. Oeuvre complète de 1929-1934. $5^{\text {ª }}$ ed. Zurich, Les Éditions Girsberger, 1952

LE CORBUSIER. Precisiones: Respecto a un Estado Actual de la Arquitectura y del Urbanismo. Barcelona, Ed. Poseidon, 1978

LEICK, G. Dictionary o9of ancient near eastern architecture, London, Routledge, 1988.

LEONARDI, R. (1890). Dizionario illistrato delle science pure applicate, 2. ed, Milano, Hoepli, 1950

LINO D'ASSUMPÇÃO, T. Diccionario dos Termos d'Architectura., Antiga Casa BertrandJosé Bastos, Lisboa, 1895

LOTZ, W. Arquitetura na Itália: 1500-1600, Cosac \& Naify edições, São Paulo 1998.

LOTZ, W. Arquitectura del renacimiento en Italia, Ed. Blume, Madrid, 1985.

MAGALHÃES, F. (org.). Malhas, Escalas, Rastros e Dobras na Obra de Peter Eisenman. Catálogo da Mostra de Peter Eisenman. Museu de Arte de São Paulo Assis Chateaubriand
São Paulo, 18 de maio-18 de junho, 1993.

MARTINI, Francesco di Giorgio. Trattati di architettura, ingegneria e arte militare, 2 vols., ed. C. Maltese, Milão, 1967.

MIGLIARI, R. Fondamenti della Rappresentazione Geometrica e Informatica dell' Architettura Edizioni Kappa, Roma, 2000

MILLON, H., e LAMPUGNANI, A. Rinascimento da Brunelleschi a Michelangelo: la rappresentazione dell'architettura, Bompiani, Milão, 1994.

MONTANER, J. M. Después Del Movimiento Moderno: Arquitectura de la segunda mitad del siglo XX. Gustavo Gili, Barcelona, 1993.

OLIVEIRA, M. M. Desenho de arquitetura pré-renascentista, EDUFBA, Salvador, 2002.

PANOFSKY, E. O significado nas artes visuais, Ed. Perspectiva, São Paulo, 1979.

PANOFSKY, E. Idea: A Evolução do Conceito de Belo, Martins Fontes, São Paulo, 1994.

PEVSNER, N. Dicionario enciclopedico de arquitetura / Nikolaus Pevsner, John Fleming, Hugh Honour, Rio de Janeiro, Artenova, 1977.

PIPES, A. Drawing for 3-Dimensional Design. Thames and Hudson, London, 1990.

PLACZEK, A. K. Encyclopedia of architects, New York, Free Press, 1982.

PORTOGHESI, P. Depois da Arquitetura Moderna. Martins Fontes, Lisboa, 1985.

PORTOGHESI, P. Dizionario enciclopédico di architettura e urbanística. 6 vols., Roma, 19681969

RAINER, W. Pedagogia da bauhaus. Tradução de João Azenha Jr., Martins Fontes, São Paulo, 1989

SAINZ, J. El dibujo de arquitectura. Madrid, Editorial NEREA, 1990

Storia dell'arte italiana. Ed. Electa Mondadori, Milão, 1988.

STUNGO, N. Frank Gehry. Cosac \& Naify, São Paulo, 2000.

SUMMERSON, J. A Linguagem Clássica da Arquitetura, Martins Fontes, São Paulo, 1997. 
TAFURI, M. L'Architettura del Umanesimo, Bari, 1965.

TAFURI, M. Ricerca del Rinascimento. Principi, città, architetti, Turim, 1992.

THE ART BOOK. Londres, Phaidon Press, 1994.

TRUCCO, G. Grande Dizionario Enciclopedico, Torino, Utet, 1933.

VIOLLET-LE-DUC, E.E. (1814-1879). Dictionnaire raisonné de l'architecture française du XIe au XVIe siècle, Paris, E. Gründ, [n.d.].

WITTKOWER, R. Sobre la arquitetura en la edad del Humanismo, Ed. Gustavo Gili, Barcelona, 1979.

WITTKOWER, R. La arquitectura del Humanismo, Editorial Gustavo Gili, Barcelona, 1979.

WITTKOWER, R. Escultura. Ed. Martins Fontes, São Paulo, 1989

ZEVI, B. Giuseppe Terragni. Barcelona: Editorial Gustavo Gili, S. A., 1982

ZEVI, B. Saber Ver a Arquitetura, Martins Fontes, São Paulo, 1978

\section{TESES E DISSERTAÇÕES}

CASTILHOS, J. R. O modelo tridimensional no ensino da arquitetura, 1959.

KATAKURA, P. O processo do projeto arquitetônico. 1997. Mestrado (Arquitetura) - Faculdade de Arquitetura e Urbanismo (FAU), Universidade de São Paulo, São Paulo, 1997.

LANCHA, J. J. A construção de uma idéia: Palladio, Le Corbusier, Terragni. 1999. Doutorado (Arquitetura) - Faculdade de Arquitetura e Urbanismo (FAU), Universidade de São Paulo São Paulo, 1999.

LANCHA, J. J. Do projeto ao objeto, do objeto ao projeto. 1993. 3v. Mestrado (Arquitetura) Escola de Engenharia de São Carlos, Universidade de São Paulo, 1993.

PASSARO, A. M. Projeto arquitetônico e a análise projetual como instrumento de trabalho. 1996 Mestrado (Arquitetura) - Faculdade de Arquitetura e Urbanismo (FAU), Universidade de São Paulo, São Paulo, 1996
PINTO, G. A. O impacto dos processos infográficos na produção da arquitetura. 1999. Doutorado (Arquitetura) - Faculdade de Arquitetura e Urbanismo (FAU), Universidade de São Paulo, São Paulo, 1999.

PRATINI, E. A interface gestual para esboços 3D em arquitetura. 1999. Doutorado (Arquitetura) - Faculdade de Arquitetura e Urbanismo (FAU), Universidade de São Paulo, São Paulo, 1999

SILVA FILHO, R. G. C. Arquitetura partindo de volumes: metodologia de projeto. 2003. Doutorado (Arquitetura) - Faculdade de Arquitetura e Urbanismo (FAU), Universidade de São Paulo, São Paulo, 2003.

\section{PERIÓDICOS}

11 Rassegna (Giuseppe Terragni 1904/1943). Bologna: Ed. C.I.P.I.A. s.r.l., 1979-Trimestral, ano IV, n. 11, set. 1982

32 Rassegna (Maquette). Bologna: Ed. C.I.P.I.A. s.r.l., 1979-Trimestral, ano IX, n. 32/4, dic 1987.

EISENMAN, P. Notes on Conceptual Architecture Towards a Definition. Casabella, $\mathrm{n}$ 359ß360, pp. 45-58, nov-dez. 1971

EISENMAN, P. Notes on Conceptual Architecture. Special Double Issue of Design Quartely n.78/79, pp. $1-5,1990$

EISENMAN, P. Visions Unfolding: Architecture in the Age of Eletronic Media.Domus, n.372, jan.1992.

GIL, A. C. Como classificar as pesquisas. in: Como elaborar projetos de pesquisa. São Paulo: Atlas, 1987. cap.4, p. 45-62

MARONI NETO, R. Como escrever um artigo científico. Revista Álvares Penteado, v.2, n.5, p. $145-164$, dez. 2000

MATOS, S. P. M. A precisão terminológica do cientista: por que deixa a desejar? Ciênciae cultura, v. 39, n. 8, p. 747-748, ago. 1987.

MILLON, H. A. eSMYTH, C. H. Michelangelo and St. Peter's: Observations on the Interio 
of the Apses, a Model of the Apse Vault, and Related Drawings, Römisches Jahrbuch für Kunstgeschichte, XVI, 137-206, 1976.

PERAZZOLI, S. Collezionismo: Le Maquette. Comprarsi il Cremlino. Revista Dove, anno 9, n. 9, pp. 124-135, set. 1999.

PODESTÀ, S. E. O croqui e a paixão. Revista Projeto, n. 180, pp. 49-85, nov. 1994.

QUINTAVALLE, A.C. Una rivoluzione? Il computer, il progetto e il medievo del design. Una riflessione su come si è trasformato nel tempo il modo di progettare oggetti. Ottagono, n. 106, pp. 146-156.

Rassegna di Architettura e Urbanistica, anno XXXIII, n.97, Aprile 1999.

RODRIGUES, M.E.F.; LIMA, M.H.D.; GARCIA, M.J. A normalização no contexto da comunicação científica. Perspectivas em ciência da informação, v.3, n.1, p.147-156, jul/dez. 1998.

SAALMAN, H. Michelangelo: Santa Maria Del Fiore and St. Peter's, Art Bulletin, n.57, pp. 374-409, 1975

SIMIELLI, M.E.R Do plano ao tridimensional: a maquete como recurso didático. Boletim Paulista de Geografia, São Paulo, n.70, pp.5-21, jul/dez. 1992.

WILTON-ELY, J. The Architectural Model: English Baroque, Apollo LXXXVIII (80), pp. 250-259.

\section{SITES:}

$<$ <ttp:/204.50.25.179 hyperscale_galleries_d_f.htm>

<http://dawww.epfl.ch/tha/acm/expo.LeCorbu/communique.html>

$<$ <ttp://my.netian.com/ dukhun/site/site.htm>

$<h t t p: / / o a s i s . h a r v a r d . e d u / h t m l / d e s 00005 . h t m l>$

<http://sar.epfl.ch/page26359.html>

<http://users.compaqnet.be/cn117945/ecorb> $<h t t p: / w w w . a r c h i m a g a z i n e . c o m>$

<http://www.artlex.com>

$<h t t p: / / w w w . a t h e n a e u m . c h>$

<http:/wwww.batipro.ma/ien//mmobilier/site/revues.htm>

<http://www.bcg.bard.edu/exhibit/ecorbusier/ecorbusierpress.htm>

বhttp://www.comune.lissone.mi.it/lecorbusier/opere_SezCaMainOuverte.htm>

$<h t t p: / / w w w . d o m u s w e b . i t>$

<http://www.elcroquis.es>

$<\mathrm{http}: / / w w w . f i n d a r t i c l e s . c o m>$

<http://www.michelangelo.com>

$<h t t p: / / w w w . m y l i n e a . c o m / v i l l g e s / p a t r i m o i n e \_a r c h i t e c t u r e>$

<http://www.nexusjournal.com/Rossi_eng.html>

〈http://www.palazzograssi.it/ita/mostre/rinascim/modelli.htm>

$<\mathrm{http}$ ://www.rappresentazione.net/Crabnebula/Documenti/Ricerca/ Modellazione\%20informatica Piero_della_Francesca Piero_della_Francesca.htm>

$<$ http://www.rappresentazione.net/Crabnebula/Documenti/Ricerca/ Modellazione\%20informatica CAD\%20o\%20modellatore/cad_o_modellatore.htm>

<http://www.rappresentazione.net/Crabnebula/Documenti/Ricerca/ Modellazione $\% 20$ inversa/Statue $\% 20$ e $\% 20$ modellazione $\% 20$ organica/ Carolina_Augusta_Austria.htm>

$<$ לhttp://www.rappresentazione.net/Crabnebula/Documenti/Ricerca/ Storia\%20dei\%20modelli/Prospettiva_e_infinito/Prospettiva_e_infinto.htm>

<http:/wwww.rappresentazione.net/Crabnebula/Documenti/Ricerca/Teoria_del_disegno/ CoseScritte/Disegno_come_modello/Disegno_come_modello.htm>

<http://www.vitruvius.com.br> 
$<$ <ttp://xarch.tu-graz.ac.at/home/rurban/course/intelligent_ambiente/

schmitt_etal.en.html>

CURCIO, L. Esperienze di um laboratório dei modelli. Disponível em: <http:// www.nexusjournal.com/Didatics-Curcio-it.html>. Acesso em: 06 Jan. 2003.

GAIANI, M. Del disegno e del modello: rappresentazioni per il Disegno Industriale. Disponível em: <http:/wwww.rappresentazione.net/Crabnebula/Documenti/Ricerca/ Teoria_del_disegno/Riflessioni_Del_disegno Kaiani_sui_modelli.htm $>$ Acesso em: 07 Dez. 2003.

MARCONI. Modello. Disponível em: <http://www.rcvr.org/scuole/marconi/areaprog/ perdida/modello.htm>. Acesso em: 03 Fev. 2003.

NEIMAN, B.; BERMÚDEZ, J. Entre la civilización analoga y la digital: El taller de medios y manipulación espacial. Disponível em: 〈http://carbon.cudenver.edu/-bneiman/

index.html> Acesso em: 15 Jan. 2004.

ROCHA, I. A. M. Os programas de computador e o processo de projeto na construção do conhecimento arquitetônico. Disponível em: <http://ncg.unisinos.br/cgrafica/ensaios/ paper/paper2.htm>Acesso em: 26 Fev 2004. 